\title{
Synthesis of New Spirocyclopropanated $\beta$-Lactams and Their Application as Building Blocks for $\beta$-Amino Acid Peptides
}

\author{
DISSERTATION \\ zur Erlangung des Doktorgrades \\ der Mathematisch-Naturwissenschaftlichen Fakultäten \\ der Georg-August Universität zu Göttingen
}

vorgelegt von

Alessandra Zanobini

aus

Florenz (Italien)

Göttingen 2005 
D7

Referent: Prof. Dr. A. de Meijere

Korreferent: Prof. Dr. L. Tietze

Tag der mündlichen Prüfung: 02 November 2005 
Die vorliegende Arbeit wurde in der Zeit von Oktober 2002 bis September 2005 im Institut für Organische und Biomolekulare Chemie der Georg-August-Universität Göttingen unter der wissenschaftlichen Anleitung von Herrn Prof. Dr. Armin de Meijere angefertigt.

Meinem Lehrer, Herrn Prof. Armin de Meijere danke ich herzlich für die interessante Themenstellung, für hilfreiche Diskussionen und Anregungen und die während dieser Arbeit erwiesene Unterstützung.

Herrn Prof. Dr. A. Brandi danke ich herzlich für die hilfreichen Diskussionen und seine stetige Unterstützung. 

To my mother 



\section{Table of Contents}

A. Introduction 1

B. Main Part 11

1. Synthesis of 3-Spirocyclopropanated-2-Azetidinones 11

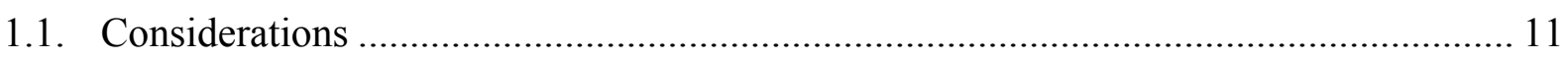

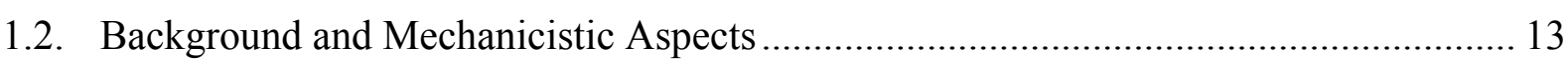

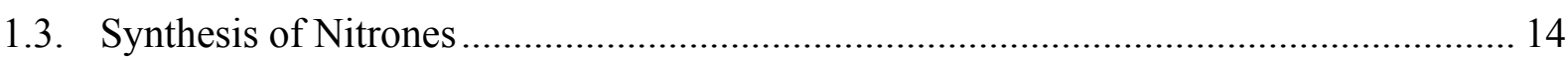

1.4. 1,3-Dipolar Cycloaddition of Nitrones to Bicyclopropylidene ……………………..... 17

1.5. Thermal Rearrangement of Spirocyclopropanated Isoxazolidines Under Acidic

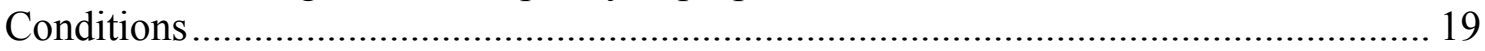

2. New One-Pot Approach to 3-Spirocyclopropanated Monocyclic $\beta$ $\begin{array}{ll}\text { Lactams } & 21\end{array}$

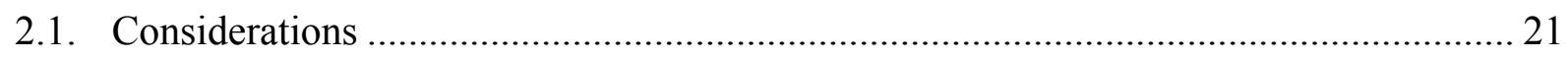

2.2. Development of a Selective One-Pot Synthesis for 2-Azetidinones .............................. 21

2.3. Extension of the One-Pot 2-Azetidinone Synthesis to Different Substrates .................. 23

2.4. Conclusions about the newly developed one-pot reaction.............................................. 32

3. Microwave Heating to Accelerate the 1,3-Dipolar Cycloadditions of Nitrones to Bicyclopropylidene 35

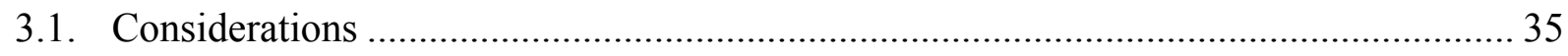

3.2. Synthesis of Isoxazolidine or Piperidone Derivatives ................................................. 36

4. $\quad \beta$-Lactam Ring-Opening with $N$ - and $O$-Nucleophiles and Formation of Dipeptides Containing 1(Aminomethyl)cyclopropanecarboxylic Acid Residues $\quad 40$

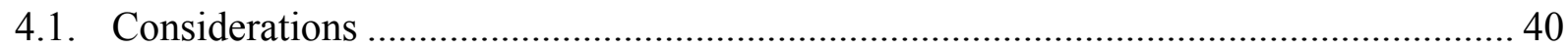

4.2. Attempted Ring-Opening of $\beta$-Lactams with $N$-Nucleophiles ..................................... 41

4.3. Changing the Character of the $N$-Protecting Group................................................... 42

4.4. Dipeptides Containing 1-(Aminomethyl)cyclopropanecarboxylic Acid Residues ........ 47

4.5. Ring Opening of $\beta$-Lactams with $O$-Nucleophiles ........................................................ 49

5. Attempted Synthesis of a Poly( $\beta$-peptide), Consisting of 1(Aminomethyl)cyclopropanecarboxylic Acid 


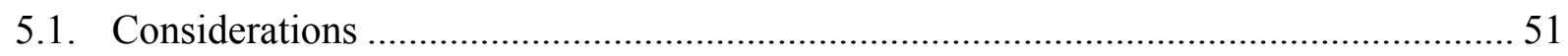

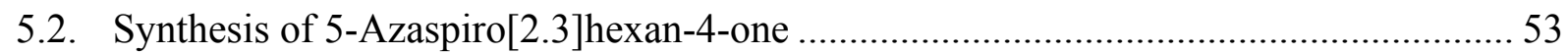

5.3. Ring Closure of Methyl 1-(Aminomethyl)cyclopropane carboxylate ........................... 55

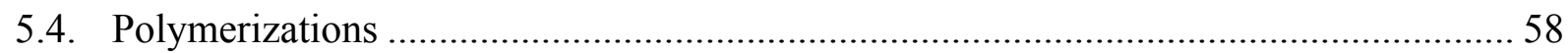

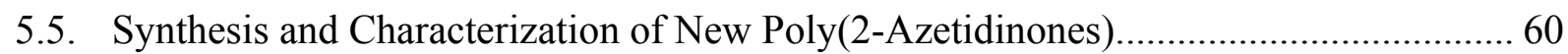

C. Experimental Part $\quad 65$

1. General Notes $\quad 65$

2. Procedures for the Synthesis and Spectral Data of the Compounds 67

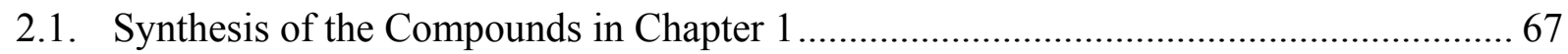

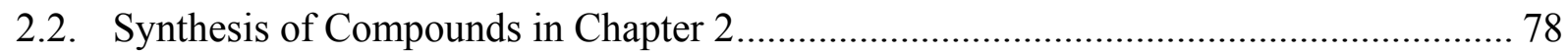

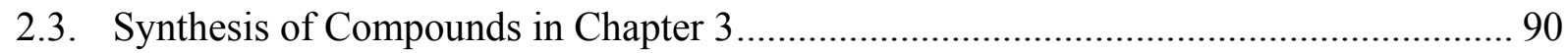

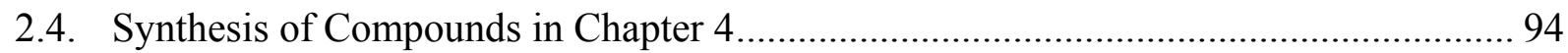

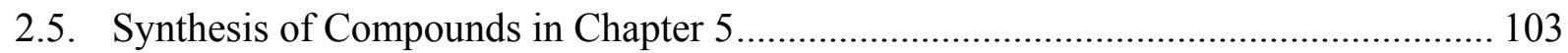

$\begin{array}{ll}\text { D. Summary } & 109\end{array}$

$\begin{array}{ll}\text { E. References } & 113\end{array}$

F. Spectral Data $\quad 125$

G. Crystal Structural Data 134

1. 8-Benzyl-9-phenyl-8-aza-7-oxadispiro[2.0.2.3]nonane (47a) 134

2. Methyl 5-Benzoyl-6-oxo-5-azaspiro[2.3]hexane-4-carboxylate (107b)

3. tert-butyl (2S,2'R)-2-\{[1-(tertbutoxycarbonylaminocyanomethyl)cyclopropylcarbonyl]amino\}3-phenylpropionate [(2S,2'R)-118] 


\section{A. Introduction}

$\beta$-Lactam antibiotics are the most frequently employed kind of antimicrobial agents. The first example ever observed was discovered by Sir A. Fleming in $1929 .{ }^{[1]}$ He found out how the growth of some bacteria stams was significantly stopped from a mold, belonging to the genus Penicillium, and named it Penicillin. In the year 1943 the group of investigators E. Chain, H. W. Florey and E. P. Abraham succeeded to isolate Penicillin G (1) (Figure 1), and postulated the structure of penicillin derivatives 2 (Figure 2). ${ }^{[2]}$ In 1945 Hodgkin and Law could obtain the X-Ray crystal analysis of Penicillin G (1). ${ }^{[3]}$

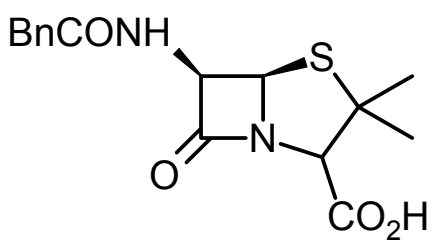

1

Figure 1. Penicillin G.

During the nineteenfifties Cephalosporin derivatives 3 were isolated (Figure 3), ${ }^{[4]}$ after Cephalosporium acremonium was isolated by Brotzu from the sea near a sewer outlet off the Sardinian coast. Crude filtrates of this fungus were found to inhibit the growth of some bacteria and to cure infections in humans.

In the subsequent decades, the researchers working with the microbiological sources as well as in the synthetic field could collect a very large number of $\beta$-lactam antibiotics. Sometimes the addition of side chains to natural nuclei made possible to produce semisynthetic compounds with greater antibacterial activity than that of the parent natural substance.

The actually available $\beta$-lactam antibiotics could be separated in nine classes: Penicillins 2 , Cephalosporins 3, Penems 4, Clavulanic acid 5, trans-Carbapenems 6, cis-Carbapenems 7, en-Carbapenems 8, Nocardicines 9, Monobactams 10 (Figure 2). 
<smiles>[R]C1C(=O)N2C1SC(C)(C)C2C(=O)O</smiles>

2<smiles>O=C(O)[C@H]1/C(=C/CO)OC2CC(=O)N21</smiles>

5<smiles>[R]C([R])=C1C(=O)N2C(C(=O)O)=C([R])C[C@H]12</smiles>

8<smiles>[X]CC1=C(C(=O)O)N2C(=O)C([R])(NC([R])=O)[C@H]2SC1</smiles>

3<smiles>[R]C1=C(C(=O)O)N2C(=O)C([R])[C@H]2C1</smiles>

6<smiles>[R]C([R])NC1C(=O)N(S(=O)(=O)O)C1([R])[R]</smiles>

9<smiles>[X]C1=C(C(=O)O)N2C(=O)C([R])C2S1</smiles>

4<smiles>[R]C1=C(C(=O)O)N2C(=O)C([R])[C@H]2C1</smiles>

7

Figure 2. Basic structures of the most important classes of $\beta$-lactam antibiotics.

A typical aspect of the research in this field is the limited number of original skeletons. The class of antibiotics received its name from the four-membered heterocycle, the $\beta$-lactam ring. This 2-azetidinone skeleton is the center of the activity respect to biological substrates. ${ }^{[5]}$

The antibacterial activity derives from inhibition of enzymes, called "Penicillin binding proteins" (PBPs) that are important for the peptidoglycan layer construction, by stabilyzing the bacterial membrane. These enzymes are transpeptidases and interact with the $\beta$-lactam ring through amide bond breaking (N1-C2 fragmentation). The reactivity toward PBPs is strongly influenced by the presence of substituents on the $\beta$-lactam or by eventually present fused rings ${ }^{[6]}$ The latter ones can increase the ring strain energy and so, favour the interaction with the transpeptidases, whose activity release this additional strain. ${ }^{[5,7]}$

Because of its unusual electronic and sterical properties, expecially cyclopropyl rings are able to influence the conformational constraint of a molecule and so its biological activity. ${ }^{[6]}$ For this reason, the spirocyclopropane unit has been several times introduced onto $\beta$-lactam antibiotics skeletons, trying to modify their reactivity, respect to biological systems. 
The spirocyclopropane has been introduced on the five-membered ring in penicillin derivatives $\mathbf{1 1},{ }^{[8,9]}$ in carbapenems $\mathbf{1 2}^{[10]}$ and in azapenames $\mathbf{1 3}^{[11]}$ (Figure 3).

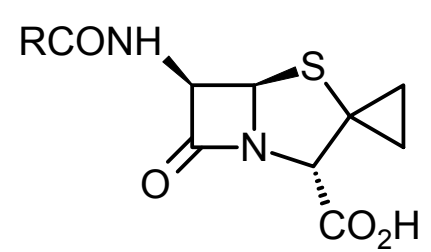

11

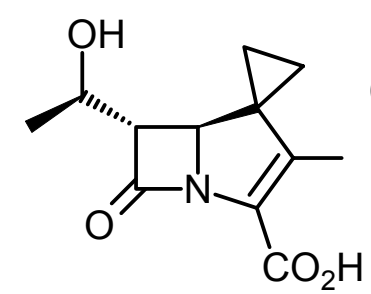

12

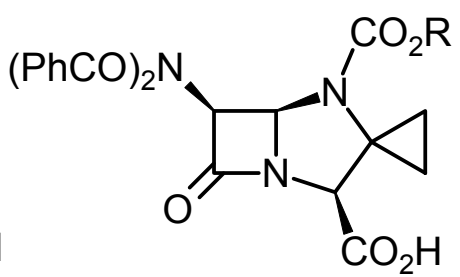

13

Figure 3. $\quad \beta$-Lactam antibiotics containing a spiroanellated cyclopropyl moiety.

A geminal disubstitution is known to generate a decrease in angle deformation, incurred upon a cyclization (Thorpe-Ingold effect). In analogy, a spirocyclopropane ring, resembling this kind of substitution, gives to the system an additional strain, which is expected to be released in the interaction toward the transpeptidases.

For this reason the spirocyclopropane moiety has already been introduced on the 2azetidinone ring in penem systems 14 and cephem systems 15 (Figure 4). ${ }^{[12]}$<smiles>[R]C1=C(C(=O)O)N2C(=O)C3(CC3)C2C1</smiles>

14<smiles>[R20]CC1=C([R6])CSC2N1C(=O)C21C([R])([R])C1([R])[R]</smiles>

15

Figure 4. $\quad \beta$-Lactam antibiotics in which the cyclopropane ring is spirofused to the $\beta$ lactam ring.

Some monocyclic spirocyclopropanated $\beta$-lactam derivatives $\mathbf{1 6}$ and $\mathbf{1 7}$ have also already been prepared by carbene addition to a preformed heterocycle, containing an exocyclic double bond (Figure 5). ${ }^{[13]}$ 


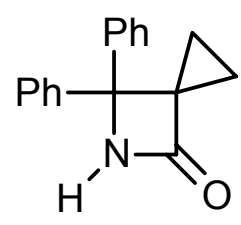

16<smiles>O=C1N(c2ccccc2)CC12CC2(Cl)Cl</smiles>

17

Figure 5. First examples of monocyclic spirocyclopropanated 2-azetidinones.

Already in the middle of the last century, the first strains of bacteria became resistent against penicillin, requiring the discovery and development of new derivatives. During the years bacterial resistance against the $\beta$-lactam antibiotics continues to increase at a dramatic rate. Although most bacteria contain PBPs, $\beta$-lactam antibiotics cannot kill or inhibit all bacteria and various mechanisms of bacterial resistance to these agents are operative. Because the $\beta$ lactam antibiotics inhibit many different PBPs in a single bacterium, the affinity for $\beta$-lactam antibiotics of several PBPs must decrease for the organism to be resistant. Altered PBPs with decreased affinity for $\beta$-lactam antibiotics are acquired by homologous recombination between PBP genes of different bacterial species. Other instances of bacterial resistance are caused by the inability of the agent to penetrate to its site of action.

Bacteria can as well destroy $\beta$-lactam antibiotics enzymatically. $\beta$-Lactamases are capable of inactivating certain antibiotics and may be present in large quantities in the cell.

For this reason new classes of antibiotics are nowadays applied in medicine as for example Aminoglycosides, Tetracyclines, Macrolides in combination with the traditionally widely used $\beta$-lactams.

In this sense the exploitation of combinatorial chemistry is very important and with that, the rapid access to differently substituted molecules, once the necessary type of structure has been recognized. Random screening allows the selection of the best structure and in addition the best substitution pattern.

Even if the oriented synthesis of $\beta$-lactam structures, with the aim to prepare a special antibiotic, might look like an overcome research, it may not be forgot how useful are this derivatives as intermediates for the organic synthesis. In fact, every single bond in a $\beta$-lactam can selectively be cleaved, ${ }^{[14]}$ favoring the 2 -azetidinone nucleus for various applications. ${ }^{[15]}$ $\alpha$ - and $\beta$-amino acids, peptides, peptidomimetics, but also several kinds of heterocycles can be prepared. The expression " $\beta$-lactam synton method" ${ }^{[16]}$ is generally accepted for all that synthetical methodologies based on $\beta$-lactam ring-fragmentations. 
For all this application the presence of the cyclopropyl ring offers new interesting hints, but of course it does require more complicated synthetical approaches to the reactive nucleus.

If a cyclic molecule is chosen as a target, it is possible to obtain it via cycloaddition of two fragments or via cyclization of a preformed chain.

An attempted approach to monocyclic spirocyclopropane-2-azetidinones by [2+2] cycloaddition has already been described previously, using different alkylidenecyclopropanes and reactive sulfonyl isocyanates as, for example, chloro- or fluorosulfonylisocyanates (21, CSI or 22, FSI). Methyl 2-chloro-2-cyclopropylideneacetate (18) does not react with CSI, even under high pressure, and other derivatives (19-20) just decompose, under these harsh conditions (Scheme 1). ${ }^{[17]}$<smiles>[R]C([R])=C1CC1</smiles>

$18 \mathrm{R}^{1}=\mathrm{Cl}$

$19 \mathrm{R}^{1}=\mathrm{OSitBuMe}_{2} \mathrm{R}^{2}=\mathrm{CO}_{2} \mathrm{Me}$ $20 \mathrm{R}^{1}=\mathrm{OSitBuMe}_{2} \mathrm{R}^{2}=\mathrm{CO}_{2} \mathrm{Me}$<smiles>[X][As](=O)(=O)N[O-]</smiles><smiles>C1=[14CH]C1</smiles>

$21 \mathrm{X}=\mathrm{Cl}$ $22 X=F$<smiles>[R]C1([R])N(S(=O)(=O)O[Na])C(=O)C12CC2</smiles>

23

Scheme 1. Attempted [2+2] cycloadditions of alkylidenecyclopropanes onto activated isocyanates 21 and 22.

When bicyclopropylidene (24), ${ }^{[18]}$ is added to CSI, the cyclopropyl cation rest in the zwitterionic intermediate 25, rearranges and the desired 3,4-dispirocyclopropane-2azetidinone 26 is formed just in a mixture with the $\gamma$-lactam 27 (Scheme 2). ${ }^{[19]}$

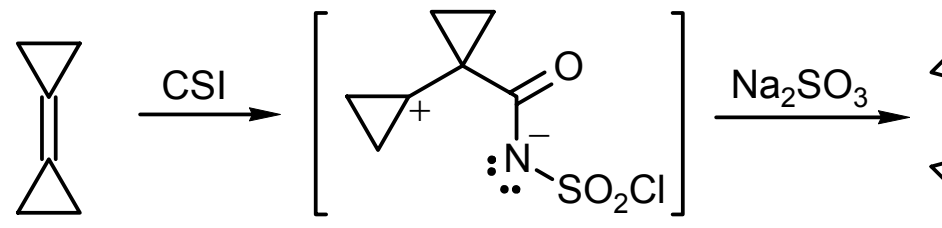

24, BCP

25

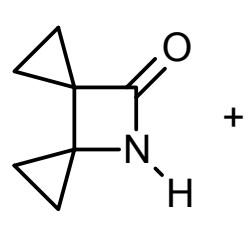

26<smiles>C=C1CNC(=O)C12CC2</smiles>

27

Scheme 2. [2+2] Cycloaddition of bicyclopropylidene (24) to chlorosulfonylisocyanates (CSI). 
A more promising, but not fully investigated, way of synthesis, developed by de Meijere, Yamamoto et al., ${ }^{[20]}$ consists in the thermal or metal-catalyzed [2+2] cycloaddition of alkoxymethylenecyclopropanes $\mathbf{2 8}$ to acceptor substituted imines $\mathbf{2 9}$ (Scheme 3).

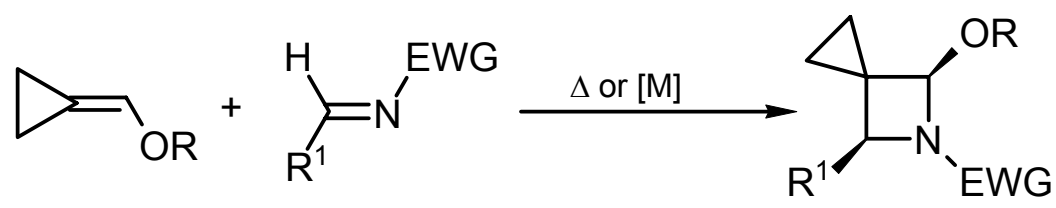

28

29

30

Scheme 3. Synthesis of substituted 3-spirocyclopropane-azetidines $30 .^{[20]}$

The oxidation of the alkoxy group to a carbonyl group may offer a rather facile two-step access to 3-spirocyclopropanated 2-azetidinones.

Because of the easy interconversion between $\beta$-amino acids and $\beta$-lactams, cyclopropylmodified $\beta$-alanines ${ }^{[21]} 31$ can also be imagined as precursors for the synthesis of spirocyclopropanated monocyclic $\beta$-lactams 33 (Figure 6).
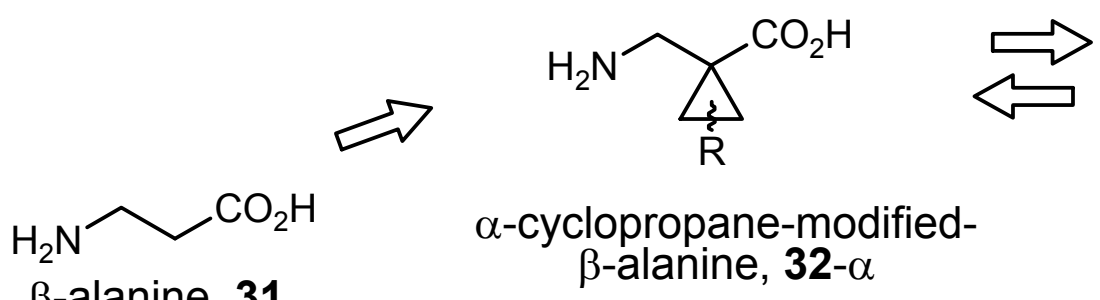<smiles></smiles>

$\beta$-alanine, 31

$\alpha$-cyclopropane-modified-

$\beta$-alanine, 32- $\alpha$
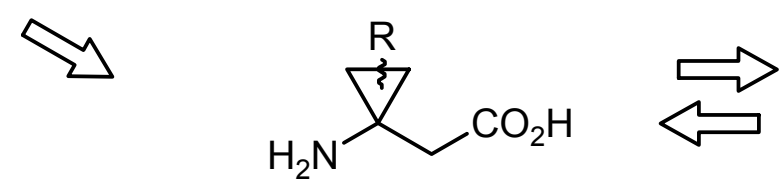

\section{$\beta$-cyclopropane-modified-}

$\beta$-alanine, 32- $\beta$

33- $\alpha$

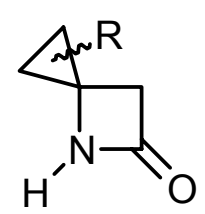

33- $\beta$

Figure 6. $\alpha$ - or $\beta$-Cyclopropyl-modified $\beta$-alanine interconversion with 3 - or 4 -spirocyclopropanated $\beta$-lactams 33- $\alpha$ or $-\beta$, respectively.

The synthesis of a spirocyclopropane-anellated $\beta$-lactam 35, has been described by de Meijere et al., ${ }^{[22,23]}$ through cyclization of the $\beta$-alanine derivative 34 (Scheme 4). 


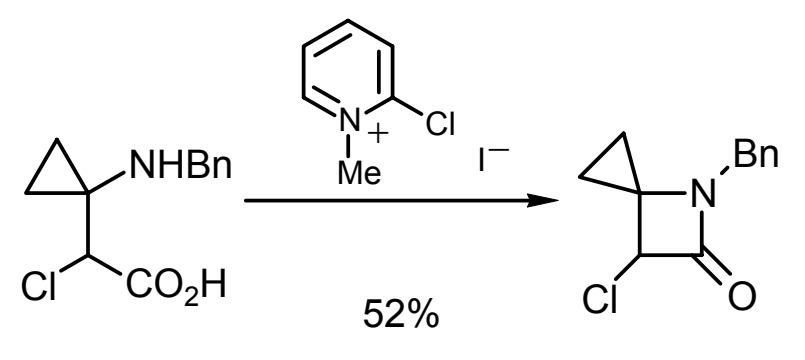

34

35

Scheme 4. Synthesis of a 4-spirocyclopropanated-2-azetidinone 35.

Since $\beta$-lactams may be considered as cyclized forms of $\beta$-amino acids in which the amino and the carboxyl groups are simultaneously protected, an application of the " $\beta$-lactam synton method ${ }^{[16]}$ is the ring opening at the N1-C2 bond for the synthesis of $\beta$-amino acids. ${ }^{[24]}$

Starting from the pioneer work of Bose, ${ }^{[25]}$ cleavage of the amide bond (N1-C2) has been the subject of many investigations. It is well known that cleavage of the 2-azetidinone ring $\mathbf{3 6}$, with nucleophilic reagents including water, usually takes place at the N1-C2 bond (Figure 7).

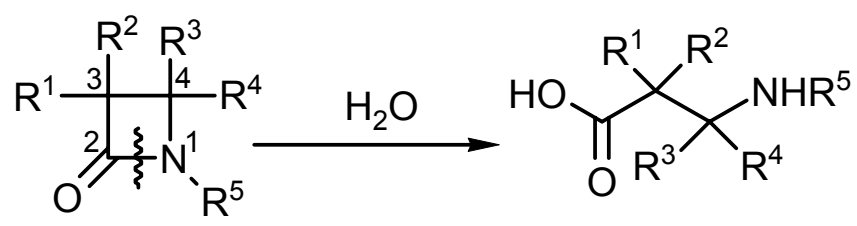

36

37

Figure 7. N1-C2 opening of the $\beta$-lactam ring leading to $\beta$-amino acids.

$\beta$-Amino acids are also present in nature, even as components of naturally occurring biologically active peptides, ${ }^{[26]}$ and their incorporation into peptides of pharmacological interest has often been found advantageous in terms of biological activity and metabolic stability. ${ }^{[27]}$

Taxol (38), which is the lead compound applied for the cancer chemotherapy, consists of a (-)-N-benzoyl-(2R,3S)-3-phenylisoserine side chain, and a second part, called 10deacetylbaccatin, presenting the diterpenic, more complex structure. The $\beta$-amino acidic chain, essential for Taxol (38) biological activity, is normally synthetically coupled with the precursor 10-deacetylbaccatin, obtained from natural sources (Figure 8). The natural reserve are scarce and not easily accessible. This process has consequently sparked the interest in the field of $\alpha$-hydroxy- $\beta$-amino acids. ${ }^{[28]} \alpha$-Hydroxy- $\beta$-amino acids, for example, are also present in various peptidic enzyme inhibitors such as Bestatin (39) (Figure 8). ${ }^{[29]}$ 


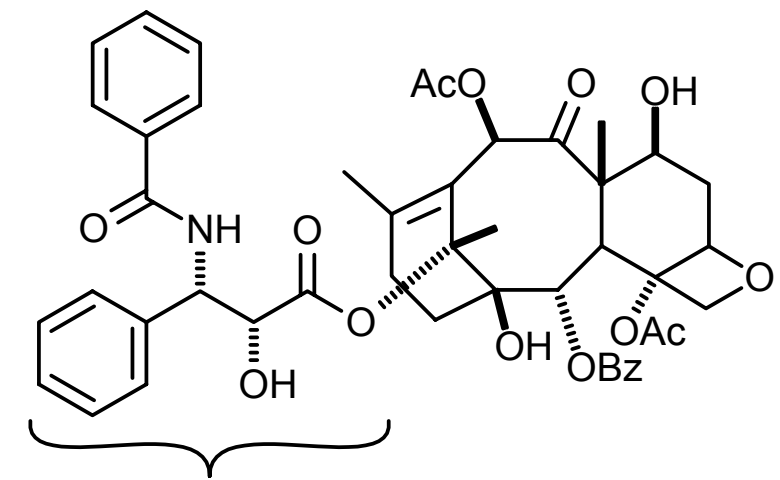

$\beta$-amino acid side chain<smiles>CC(C)C[C@H](NC(=O)[C@@H](O)[C@H](N)Cc1ccccc1)C(=O)O</smiles>

39 Bestatin

Figure 8. Bestatin and Taxol are important biologically active molecules, both containing $\beta$-amino acid moieties.

In addition, recent studies concerning oligo- $\beta$-peptides have revealed new opportunities for the development of specific helical conformations and $\beta$-sheet type structures. ${ }^{[27]}$

Oligomers 40a-d, derived from geminally $C(\alpha)$-disubstituted $\beta$-amino acids ( $\beta^{2,2}$-units), have been prepared from 1-(aminomethyl)cyclopropanecarboxylic acid (41). ${ }^{[30]}$

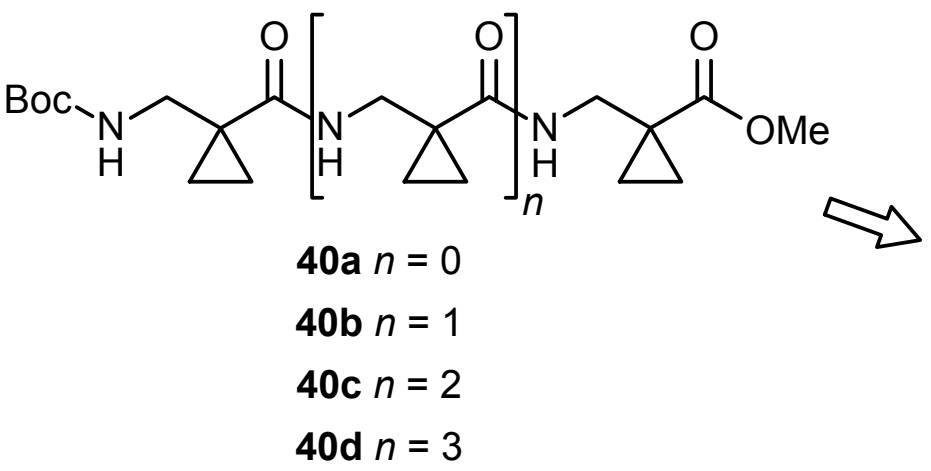<smiles>NCC1(C(=O)O)CC1</smiles>

41

Figure 9. $\quad \beta$-Oligopeptides 40 consisting of 1-(aminomethyl)cyclopropane carboxylic acid (41) units.

The presence of an additional anchor on the $\beta$-amino acid chain, like a cyclopropane ring, has shown interesting consequences for the helical supramolecular structure. Cyclopropanecarbonyl derivatives (like cyclopropyl carbenium ions) are subjected to a hyperconjugative effect, favoring the so-called bisecting conformation. Both the $s$-cis and the $s$-trans-form are stabilized by interaction of the HOMO, $\pi$-type Walsh orbitals of the cyclopropane ring 
with the LUMO, antibonding $\pi^{*}$ orbital of the $\mathrm{C}=\mathrm{O}$ bond. A search in the Cambridge Files (CCDC) for structures like 42, has shown that seven of the eleven there found, have the $s$ - cis conformation, that, according to theoretical and spectroscopic data, is the more stable. ${ }^{[31]}$ All cyclopropane-carbonyl moieties in the oligomers $\mathbf{4 0}$ have the $s$-cis conformation $\mathbf{4 2 a}$ with the $\mathrm{C}=\mathrm{O}$ group pointing over the three-membered ring. The rotational barrier for the interconversion of the $\mathrm{s}-$ cis $\mathbf{4 2 a}$ and $s$-trans $\mathbf{4 2 b}$ conformations is about $6 \mathrm{Kcal} / \mathrm{mol}$ and becomes zero, increasing the ring-size from cyclopropane to cyclohexane (Figure 10).<smiles>[R]OC(=O)C1([R])CC1</smiles>

42
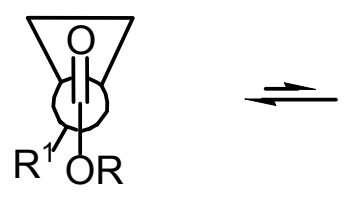

$\Delta \mathrm{G}^{\neq}=6 \mathrm{kcal} / \mathrm{mol}$

$s-c i s$

42a

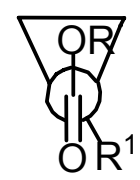

s-trans

$42 b$

$\mathrm{R} \neq \mathrm{H}$

Figure 10. Conformational considerations about cyclopropylcarbonyl moieties 42 .

The bisecting effect and the large exocyclic bond angle $\left(120^{\circ}\right)$ are proposed to provide the "ordering elements", which lead to the secondary structural motif in the oligomers 40a-d. Five atoms $\mathrm{H}-\mathrm{N}-\mathrm{C}(\mathrm{O})-\mathrm{C}\left(\mathrm{H}_{2}\right)-\mathrm{C}\left(\mathrm{H}_{2}\right)$ of a single amino acid result fixed in a common plane by $\mathrm{H}$-bonding, to form a boat-like eight-membered ring with three atoms $\mathrm{N}(\mathrm{H})-\mathrm{C}=\mathrm{O}$ of a neighbor unit (Figure 11).
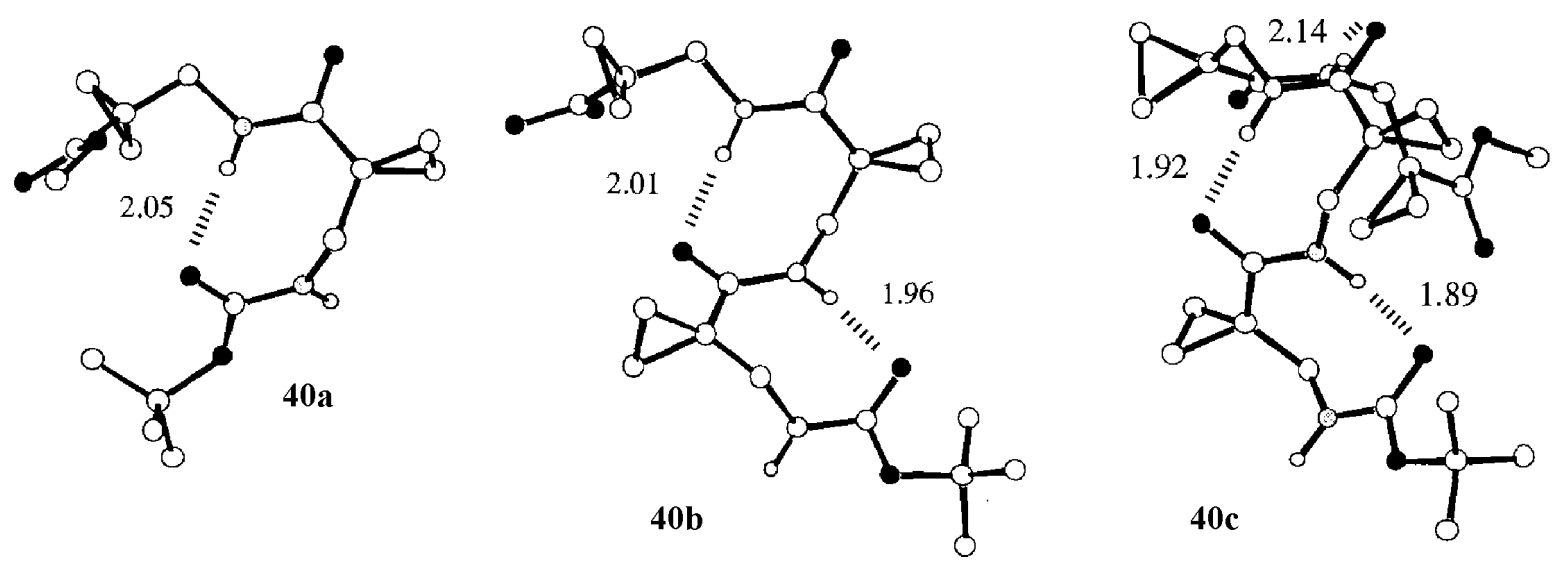

Figure 11. $X$-Ray crystal structures of the $\beta$-amino-acid derivative $\beta^{2,2}$-di-, $\beta^{2,2}$-tri- and $\beta^{2,2}$-tetrapeptides 40a, 40b, and 40c. ${ }^{[30]}$ 
It might be interesting to examin if this regularity and high organization are reproducible in much longer chains, like in a poly- $\beta$-amino acid.

In this sense this work is directed towards the following aims:

- The synthesis of several different 3-spirocyclopropanated-2-azetidinones 33- $\alpha$, formally derived from 1-(aminomethyl)cyclopropane carboxylic acid (41).

- Development of a fast one-step synthesis of 3-spirocyclopropanated-2-azetidinones 33- $\alpha$, using the microwave technology, and optimization of the reaction conditions.

- The synthesis of dipeptides containing $\alpha$-cyclopropyl- $\beta$-alanine units 32- $\alpha$, via N1-C2 ring-opening in the synthesized $\beta$-lactams 33- $\alpha$, using the amino group nucleophilicity of amino esters.

- The attempt to obtain spirocyclopropanated-poly- $\beta$-propiolactams $\mathbf{4 0}$. 


\section{B. Main Part}

\section{Synthesis of 3-Spirocyclopropanated-2-Azetidinones}

\subsection{Considerations}

Because of the wide-ranging significance of $\beta$-lactams in organic synthesis and in pharmacology, the development of efficient methods for their preparation plays an important role.

The feature of a spirocyclopropyl ring bonded to the azetidinone renders this molecular skeleton even more interesting. From the pharmacological point of view the spiro-fused small ring might be important, because it is expected to introduce additional ring-strain, ${ }^{[5-7]}$ which is decisive to favour the interaction with the PBPs, and so the weakening of the cell-wall in bacteria. From the synthetic point of view the spirocyclopropane moiety would enrich in number and in interest the applications included in the " $\beta$-lactam synton method". [16]

Brandi et al. have investigated the chemistry of nitrones $\mathbf{4 4}$, whose 1,3-dipolar cycloaddition to the alkylidenecyclopropane $\mathbf{4 3}$ leads to a mixture of isoxazolidine regioisomers $\mathbf{4 5}$ and $\mathbf{4 6}$, where the cyclopropane ring is located on the C-4 or on the C-5, respectively (Scheme 5). ${ }^{[32]}$

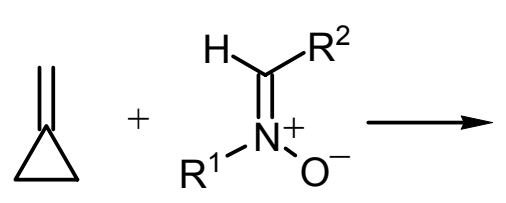

43

44

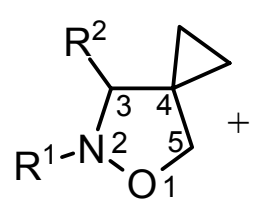

45<smiles>[R]C1CC2(CC2)ON1[R]</smiles>

46

Scheme 5. 1,3-Dipolar cycloaddition of nitrones 44 to methylenecyclopropane (43).

As the result of the combination of the strained small ring and the adjacent weak N-O bond, isoxazolidines 46 show a distinctive chemistry and can be converted by thermal rearrangement, which is generally named Brandi-Guarna reaction, ${ }^{[33]}$ to tetrahydropyridones 48 (Scheme 6). ${ }^{[32]}$

More recently it was reported by the same group, that 5-spirocyclopropanated isoxazolidines 46, can rearrange to azetidin-2-ones 52, by heating in the presence of a protic acid (Scheme 6). ${ }^{[34]}$ 


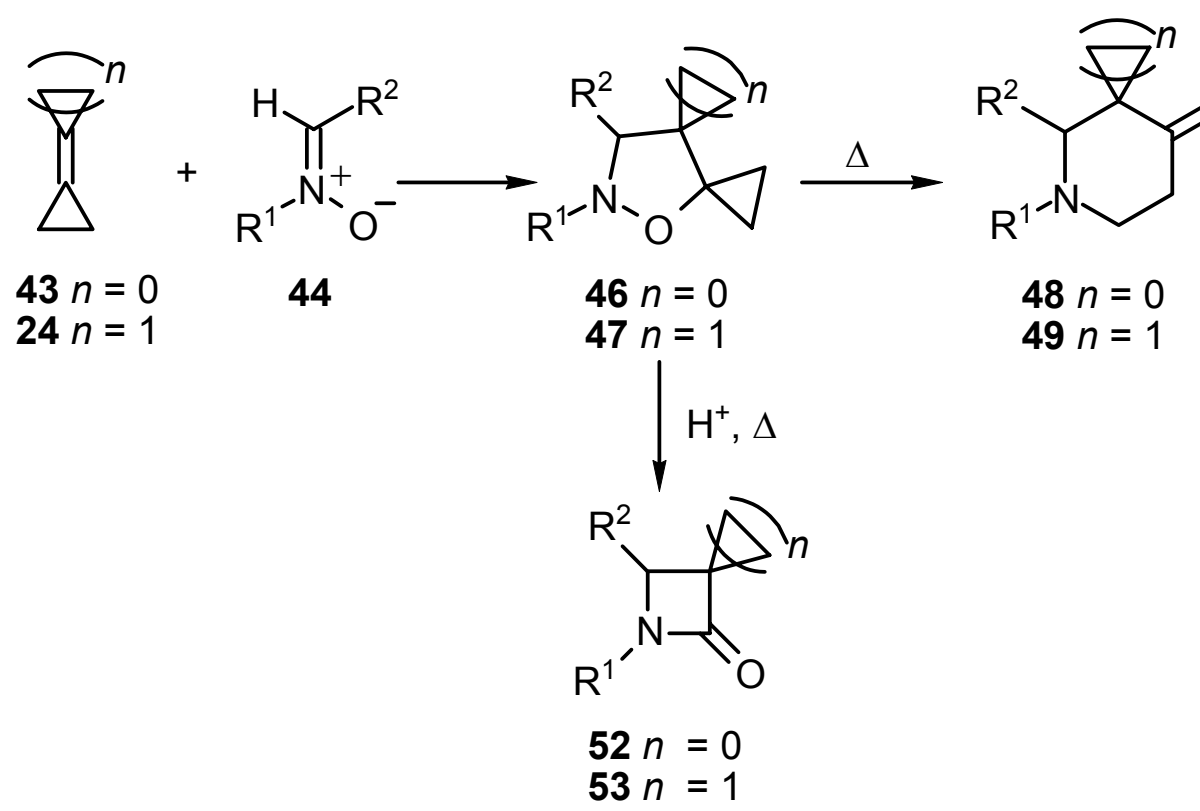

Scheme 6. Formation of isoxazolidines 46 and 47 and their possible rearrangement pathways.

If bicyclopropylidene (24) is used as dipolarophile, the cycloaddition with nitrone 44 furnishes $\mathbf{4 7}$ as only product. The thermal rearrangement of $\mathbf{4 7}$ leads to spirocyclopropanated tetrahydropyridones $49 .{ }^{[32]}$ If the same isoxazolidine 47 is heated under acidic conditions, should occur the rearrangement to $\beta$-lactam $\mathbf{5 3}$, still bearing a spirocyclopropane ring in $\alpha$ position respect to the carbonyl group (Scheme 6).

A variation of the nitrone chemistry in which $\beta$-lactams are the final products, is the copper catalyzed Kinugasa-Miura reaction. ${ }^{[35 a, b]}$ Terminal alkynes 55 react with 1,3-dipoles 44 in the presence of a catalytic amount of the metal to give azetidin-2-ones 56 (Scheme 7). An enantioselective variation of this process has been recently presented by $\mathrm{Fu}$ et al., who prepared several $\beta$-lactams $\mathbf{5 6}$ introducing in the synthesis the use of chiral bis(azaferrocene) ligands. ${ }^{[35 c]}$

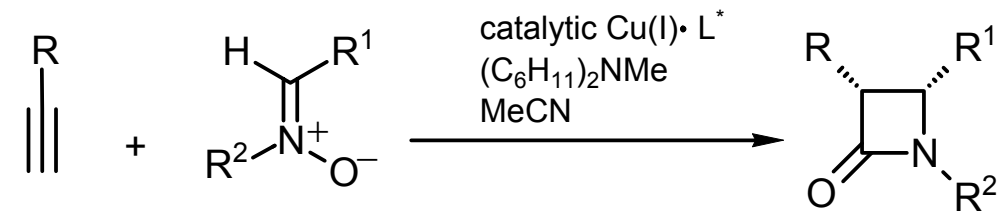


Scheme 7. The Kinugasa-Miura reaction.

However even this newly developed method cannot substitute the rearrangement of 5-spirocyclopropanated isoxazolidine, when 24 is used as dipolarophile. The final structure complexity (product 53, Scheme 6) is increased from the presence of a spirocyclopropyl group, which cannot be introduced with the Kinugasa-Miura reaction.

\subsection{Background and Mechanicistic Aspects}

Two different mechanisms have been proposed for the acid catalyzed rearrangement of $\mathbf{4 6}$ and 47. After protonation of the nitrogen atom to form $\mathbf{5 0}$, the reaction can proceed following a ionic mechanism (Scheme 8, pathway a), in which the labile $\mathrm{N}-\mathrm{O}$ bond is broken and a contemporary ring enlargement takes place, with formation of an oxetane in $\mathbf{5 1}$. The latter can undergo a retro Paternó-Büchi reaction, which liberates ethylene, while the carbonyl group is attacked from the lone electron pair of the nitrogen atom to give the four-membered rings $\mathbf{5 2}$ or 53, respectively (Scheme 8).

As a second possible pathway a radical process can be imagined (Scheme 8, pathway b). After protonation of the nitrogen atom to form 50, the N-O bond can break homolitically, followed by rearrangement of the cyclopropyloxy radical to an oxoethyl radical. Supported by a strong intramolecular hydrogen bond, radical ricombination in $\mathbf{4 8 - 4 9}$ is suppressed, producing exclusively ring closure to the two $\beta$-lactams $\mathbf{5 2}$ and $\mathbf{5 3}$, which is accompanied by liberation of ethylene (Scheme 8). ${ }^{[34 a]}$

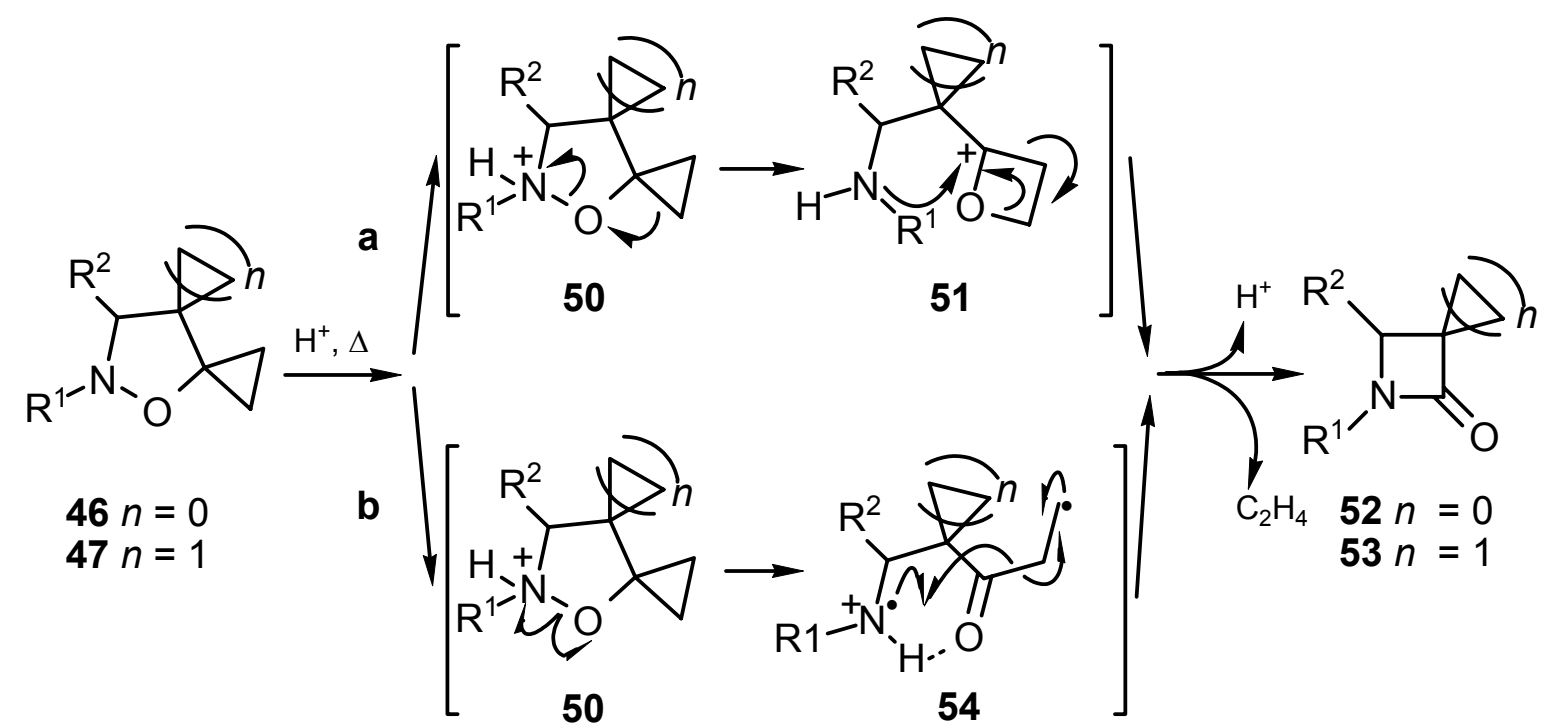

Scheme 8. Proposed mechanisms for the rearrangement under acidic conditions. 
Detailed studies have shown that the radical mechanism (Scheme 8, patway b), seems to be the most probable one. ${ }^{[34 \mathrm{~b}]}$ Cyclization reaction of aminium radical intermediates as $\mathbf{5 4}$ are already well known from the Hoffman-Löffler reaction. ${ }^{[36]}$

Some other known ring contraction from isoxazolidine to $\beta$-lactam have been reported, ${ }^{[37-39]}$ but no cyclopropyl-fragment rearrangements have ever been involved. The known examples refer to 5-nitroisoxazolidine 57, 5-cyanoisoxazolidine 58 and 5-thioisoxazolidines 59, whose rearrangement requests strongly basic conditions to deprotonate the position 5 (Figure 12).<smiles>CC(C)(C)N1OC([N+](=O)[O-])[C@H](C#N)C1c1ccccc1</smiles>

57<smiles>CC(C)(C)N1OC(C#N)[C@H]([N+](=O)[O-])C1c1ccccc1</smiles>

58<smiles></smiles>

59

Figure 12. Isoxazolidine capable to rearrange to $\beta$-lactams.

The rearrangement of isoxazolidine $\mathbf{4 6}$ and $\mathbf{4 7}$ is totally new in synthetic chemistry, but reminds a process that occurs in nature: the enzymatic conversion of 1-aminocyclopropane carboxylic acid ACC $\mathbf{6 0}$ into ethylene during the plant growth regulation and the maturation of fruits (Figure 13)..$^{[6 b, 40]}$<smiles>C[C@H](O[C@H](C)C(=O)O)C(C)(C)C</smiles>

Figure 13. 1-Aminocyclopropane carboxylic acid.

\subsection{Synthesis of Nitrones}

In order to obtain 3-spirocyclopropanated-2-azetidinones several differently substituted nitrones 44a-i have been prepared (Figure 14), and subsequently their 1,3-dipolar cycloadditions with bicyclopropylidene (24) have been performed. 
<smiles>[O-]/[N+](=C\c1ccccc1)c1ccccc1</smiles><smiles>COC(/C=[N+](\[O-])Cc1ccccc1)OC</smiles>

$44 a$<smiles>N#C/C=[N+](\[O-])Cc1ccccc1</smiles>

44c<smiles>N#C/C=C(\[15NH2])[N+]([O-])=[18O]</smiles>

44d<smiles>[O-][N+](=Cc1ccccc1I)c1ccccc1</smiles>

$44 e$<smiles>CCCCC(C)(C)C</smiles>

$44 f$<smiles>[R16][N+]([O-])=C[NH+]=C</smiles>

$44 \mathrm{~g}$<smiles>[O-][N+]1=CCCC1</smiles>

44h<smiles>O=C(OC1CCCCC1)C(Br)=[N+]([O-])Br</smiles>

Figure 14. Structures of synthetized nitrones used for the 1,3-dipolar cycloaddition.

The nitrones 44a and 44h were obtained under dehydrogenation of $N, N$-dibenzylhydroxylamine ${ }^{[41]}$ and $N$-hydroxypyrrolidine. ${ }^{[42]}$ The reactions were performed using lead acetate and yellow mercury oxide, respectively, following known procedures (Scheme 9).

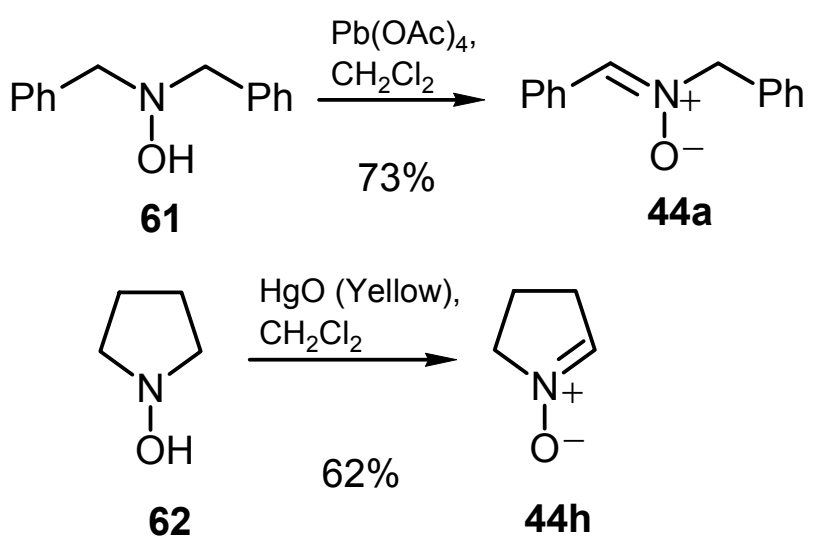

Scheme 9. Synthesis of nitrones by oxidation of symmetrically $N, N$-disubstituted hydroxylamines 61 and 62 .

The $N$-benzyl-C-cyanonitrone (44c) and $N$-(p-methoxybenzyl)-C-cyanonitrone (44d) were obtained using the first two steps of a process, that has been developed for the synthesis of hydroxylamines starting from primary amines. This method consists in three steps. First the primary amine 63 is mono-cyanomethylated, the formed adduct 64 is oxidized to the nitrone using $m$ CPBA and finally the hydroxylaminolysis is achieved with hydroxylamine hydrochloride (Scheme 10). ${ }^{[43]}$ 
The reported yield for 44c (78\%) was reproduced and nitrone 44d was obtained as a 1:4 mixture of $E$ - and $Z$-isomers, in quantitative yield.

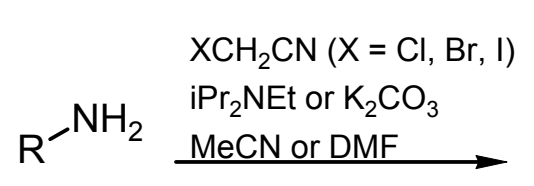

63

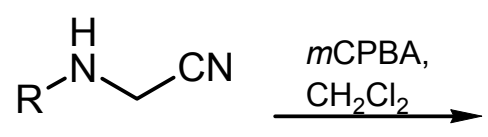

64

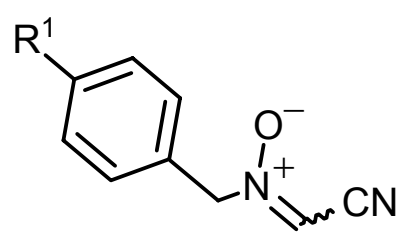

44c $\mathrm{R}^{1}=\mathrm{H}, 78 \%$

44d $\mathrm{R}^{1}=\mathrm{OMe}$, quant.

1) $\mathrm{NH}_{2} \mathrm{OH} \bullet \mathrm{HCl}$, $\mathrm{MeOH}, 60^{\circ} \mathrm{C}$ 2) $(\mathrm{COOH})_{2}, \mathrm{MeOH}$

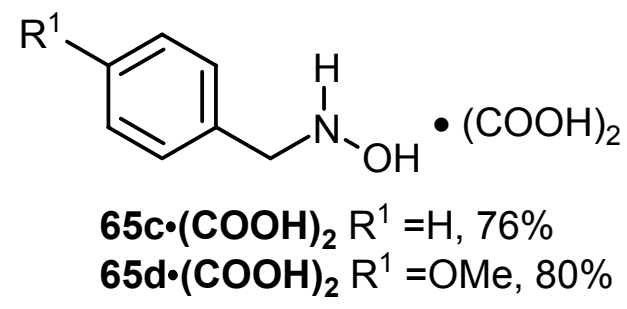

Scheme 10. Synthesis of primary $N$-hydroxylamine salts 65 .

The hydroxylamine $\mathbf{6 5 c} \cdot(\mathbf{C O O H})_{2}$ was prepared reproducing the reference yield $(76 \%){ }^{[43]}$ while $65 \mathrm{~d} \cdot(\mathbf{C O O H})_{2}$ was obtained with the same method in $80 \%$ yield (Scheme 10$)$. The nitrones $\mathbf{4 4 b}, \mathbf{e}-\mathbf{g}$, $\mathbf{i}$ were obtained by means of traditional condensation methods, i.e. reacting $N$ - alkyl hydroxylamines with a carbonyl derivative (Scheme 11). ${ }^{[4]}$

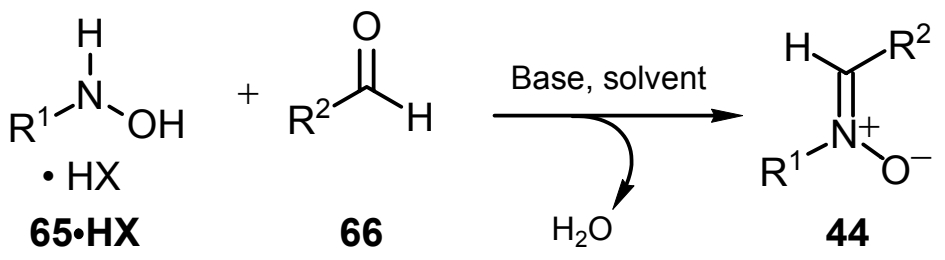

Scheme 11. Synthesis of nitrones $44 \mathbf{b}$, e-g, $\mathbf{i}$ via condensation of a $N$-hydroxylamine salt $\mathbf{6 5} \cdot \mathbf{H X}$ with a carbonyl derivative $\mathbf{6 6}$.

\begin{tabular}{ccccccccc}
\hline Entry & $\mathbf{4 4}$ & $\mathrm{R}^{1}$ & $\mathrm{HX}$ & $\mathrm{R}^{2}$ & Solvent & Temp [ $\left.{ }^{\circ} \mathrm{C}\right]$ & Base & Yield [\%] \\
\hline 1 & $\mathbf{b}$ & $\mathrm{Bn}$ & $(\mathrm{COOH})_{2}$ & $\mathrm{CO}_{2} \mathrm{Me}$ & $\mathrm{Et}_{2} \mathrm{O}$ & 0 & $\mathrm{~K}_{2} \mathrm{CO}_{3}$ & 63 \\
2 & $\mathbf{e}$ & $\mathrm{Bn}$ & $\mathrm{HCl}$ & $\mathrm{oC}_{6} \mathrm{H}_{4} \mathrm{I}$ & $\mathrm{EtOH}$ & 100 & $\mathrm{NaOAc}$ & 68 \\
3 & $\mathbf{f}$ & $\mathrm{PMB}$ & $(\mathrm{COOH})_{2}$ & $\mathrm{oC}_{6} \mathrm{H}_{4} \mathrm{I}$ & $\mathrm{THF}$ & 25 & $\mathrm{Et}_{3} \mathrm{~N}$ & 89 \\
4 & $\mathbf{g}$ & $\mathrm{PMB}$ & $(\mathrm{COOH})_{2}$ & $\mathrm{H}$ & $\mathrm{EtOH}$ & 25 & $\mathrm{Et}_{3} \mathrm{~N}$ & 88 \\
5 & $\mathbf{i}$ & $\mathrm{Bn}$ & - & $\mathrm{CO}_{2} \mathrm{CHex}$ & $\mathrm{C}_{6} \mathrm{H}_{6}$ & 80 & - & 76 \\
\hline
\end{tabular}

Table 1. Conditions for the condensation to nitrones 44 . 
The conditions necessary for the condensation (Scheme 11) depended on the derivative and varied in a wide range from $0{ }^{\circ} \mathrm{C}$ in dry ether for $\mathbf{4 4 b}$, to refluxing benzene requested for the synthesis of 44i (Table 1).

$N$-(p-Methoxybenzyl)-methyleneamine- $N$-oxide (44g) was synthesized according to the literature, but using triethylamine as the base instead of sodium acetate (Scheme 12 and Table 1, Entry 4). ${ }^{[45]}$ Formaldehyde- $N$-benzyloxime (44j) was not isolated following the literature procedure. ${ }^{[46]}$ The white solid initially obtained after solvent evaporation under reduced pressure, turned to a yellow oil, during the attempt to collect it from the flask with a simple trituration-suction procedure (Scheme 12).

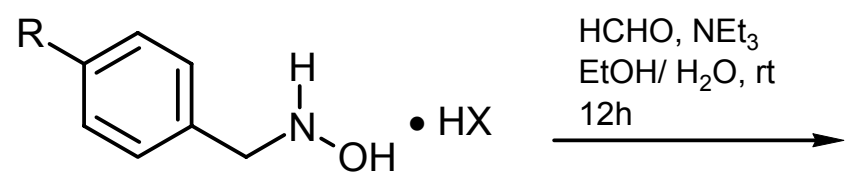

$\begin{array}{ll}65 \mathrm{c} \cdot \mathrm{HCl} & \mathrm{R}=\mathrm{H} \\ 65 \mathrm{~d} \cdot(\mathrm{COOH})_{2} & \mathrm{R}=\mathrm{OMe}\end{array}$<smiles>[R]c1ccc(C[N+](=C)[O-])cc1</smiles>

44j $\mathrm{R}=\mathrm{H}$,

44g $\mathrm{R}=\mathrm{OMe}, 88 \%$

Scheme 12. Condensation of formaldehyde $66-\mathrm{H}$ as a solution $8 \mathrm{M}$ in water to give nitrones $44 \mathrm{~g}$ and $44 \mathrm{j}$.

\subsection{1,3-Dipolar Cycloaddition of Nitrones to Bicyclopropylidene}

The olefine $\mathbf{2 4}$ is easily available even in large scale for synthetic purposes, with a relatively new three steps synthesis. ${ }^{[18]}$ This process was optimized by de Meijere et al., and applies as key step the Ti-mediated cyclopropanation, developed by Kulinkovich (Scheme 13). ${ }^{[4]}$

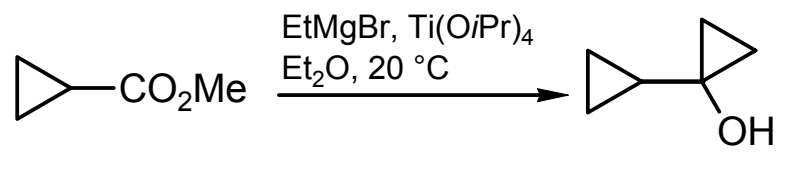

90

91
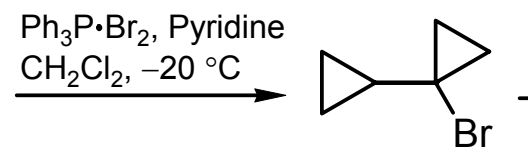

tBuOK DMSO, $25^{\circ} \mathrm{C}$

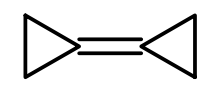

92

Scheme 13. Synthesis of bicyclopropylidene 24 . 
Bicyclopropylidene (24) shows a distinctive behaviour respect to other tetraalkyl-substituted olefines, which are not able to undergo 1,3-dipolar cycloadditions with nitrones. ${ }^{[48]}$ As could be expected according to literature precedents, ${ }^{[34,49,50]}$ 1,3-dipolar cycloaddition of 44a-g, ${ }^{[41-47]}$ to $\mathbf{2 4}$ in benzene or without any solvent, at ambient or elevated temperature, gave

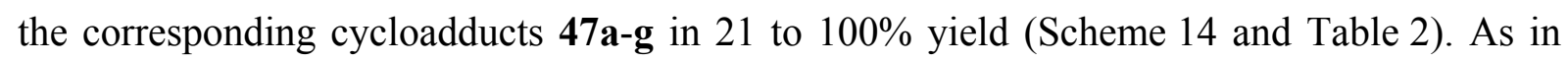
the previous cases, very long reaction times were necessary for these cycloadditions to go to completion, because they have to be carried out at moderate temperatures to avoid the thermal rearrangement of the cycloadducts at elevated temperature. ${ }^{[32]}$

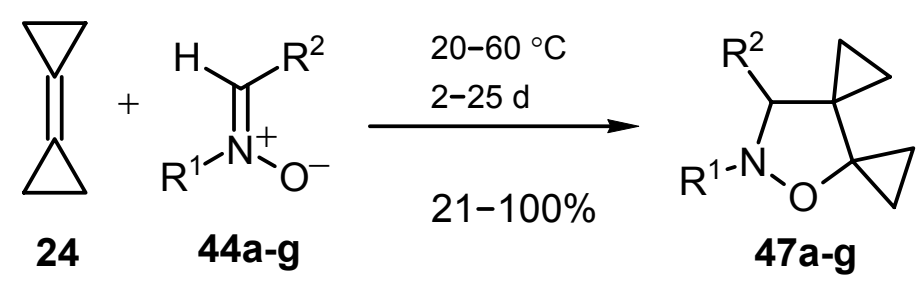

Scheme 14. 1,3-Dipolar cycloaddition of nitrones 44a-g onto bibyclopropylidene (24).

\begin{tabular}{cccccccc}
\hline Entry & $\mathbf{4 4}$ & $\mathrm{R}^{1}$ & $\mathrm{R}^{2}$ & Temp. $\left[{ }^{\circ} \mathrm{C}\right]$ & Time[d] & $\mathbf{4 7}$ & Yield [\%] \\
\hline 1 & a & $\mathrm{Ph}$ & $\mathrm{Bn}$ & 60 & 25 & a & 95 \\
2 & $\mathbf{b}$ & $\mathrm{CO}_{2} \mathrm{Me}$ & $\mathrm{Bn}$ & 45 & 2 & $\mathbf{b}$ & 100 \\
3 & $\mathbf{c}$ & $\mathrm{CN}$ & $\mathrm{Bn}$ & 20 & 8 & $\mathbf{c}$ & 94 \\
4 & $\mathbf{d}$ & $\mathrm{CN}$ & $\mathrm{PMB}$ & 20 & 8 & $\mathbf{d}$ & 100 \\
5 & $\mathbf{e}$ & $\mathrm{olC}_{6} \mathrm{H}_{4}$ & $\mathrm{Bn}$ & 60 & 6 & $\mathbf{e}$ & 88 \\
6 & $\mathbf{f}$ & $\mathrm{olC}_{6} \mathrm{H}_{4}$ & $\mathrm{PMB}$ & 65 & 4 & $\mathbf{f}$ & 75 \\
7 & $\mathbf{g}$ & $\mathrm{H}$ & $\mathrm{PMB}$ & 20 & 6 & $\mathbf{g}$ & 21 \\
\hline
\end{tabular}

Table 2. Reaction conditions and yields for the 1,3-dipolar cycloadditions to bicyclopropylidene (24) of nitrones $44 a-g$.

The structures of 47a-g were assigned on the basis of their NMR spectra. However, initially no signals of the benzylic $\mathrm{CH}_{2}$ group as well as nitrile and quaternary spirocyclopropane carbon atoms in position 4 were found in the ${ }^{13} \mathrm{C}$ NMR spectra of 8-benzyl-9-cyano-8-aza-7oxadispiro[2.0.2.3]nonane (47c) and 9-cyano-8-(4-methoxybenzyl)-8-aza-oxadispiro[2.0.2.3]nonane (47d) at room temperature under standard conditions. Additional high temperature measurement $\left(100{ }^{\circ} \mathrm{C}\right.$ in $\left.\mathrm{C}_{2} \mathrm{D}_{2} \mathrm{Cl}_{4}\right)$ were run to complete the characterization. The 
structural features of the cycloadduct $\mathbf{4 7 b}$ were established by an X-Ray crystal structure analysis (Figure 15).

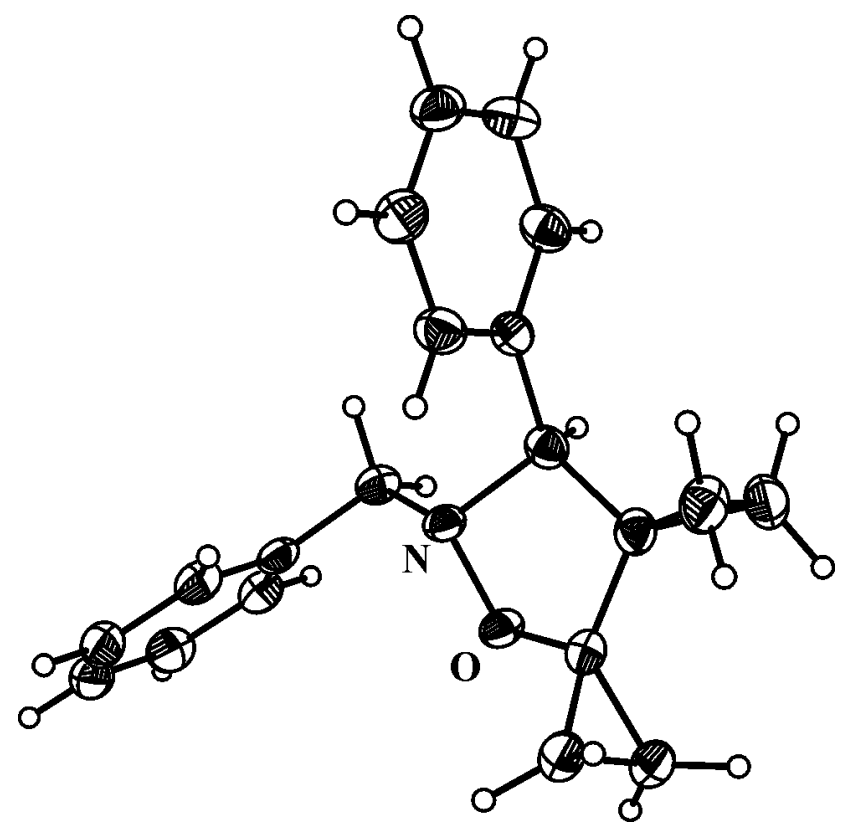

Figure 15. X-Ray crystal structure analysis of 8-benzyl-9-phenyl-8-aza-7-oxadispiro[2.0.2.3]nonane (47a).

\subsection{Thermal Rearrangement of Spirocyclopropanated Isoxazolidines Under Acidic Conditions}

Treatment of the compounds 47 a-e with trifluoroacetic acid (TFA) in acetonitrile at $70{ }^{\circ} \mathrm{C}$ furnished the corresponding 3-spirocyclopropanated $\beta$-lactams 53a-e in yield ranging from 75 to $94 \%$, respectively, after purification by column chromatography (Scheme 15 and Table 3). Thus, the overall yields of this two step process from nitrones 44a-e to 5-azaspiro[2.3] hexan4-ones 53a-e, range from 70 to $94 \%$.

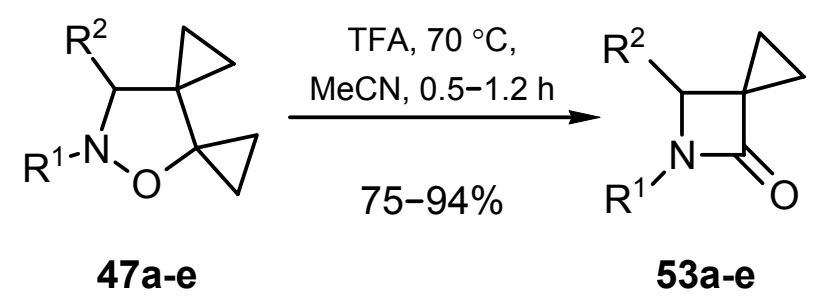

Scheme 15. Thermal rearrangement under acidic conditions for the cycloadducts $47 \mathbf{a}-\mathbf{e}$. 


\begin{tabular}{ccccccc}
\hline Entry & $\mathbf{4 7}$ & $\mathrm{R}^{1}$ & $\mathrm{R}^{2}$ & Time[h] & $\mathbf{5 3}$ & Yield [\%] \\
\hline 1 & $\mathbf{a}$ & $\mathrm{Ph}$ & $\mathrm{Bn}$ & 3 & $\mathbf{a}$ & 75 \\
2 & $\mathbf{b}$ & $\mathrm{CO}_{2} \mathrm{Me}$ & $\mathrm{Bn}$ & 12 & $\mathbf{b}$ & 78 \\
3 & $\mathbf{c}$ & $\mathrm{CN}$ & $\mathrm{Bn}$ & 12 & $\mathbf{c}$ & 75 \\
4 & $\mathbf{d}$ & $\mathrm{CN}$ & $\mathrm{PMB}$ & 12 & $\mathbf{d}$ & 94 \\
5 & $\mathbf{e}$ & $\mathrm{olC}_{6} \mathrm{H}_{4}$ & $\mathrm{Bn}$ & 1 & $\mathbf{e}$ & 89 \\
\hline
\end{tabular}

Table 3. Reaction conditions and yields for the rearrangements to 53a-e.

In the case of the pyrroline- $N$-oxide $(\mathbf{4 4 h})$, the cycloadduct $\mathbf{7 0},{ }^{[50]}$ afforded, instead of the expected carbapenem 71, the $\beta$-homoproline derivative 72 (Scheme 16). This kind of process has already been observed for the thermal rearrangement under acidic condition of 5-spirocyclopropanated isoxazolidines $\mathbf{4 6}$ derived from cyclic nitrones. ${ }^{[51]}$

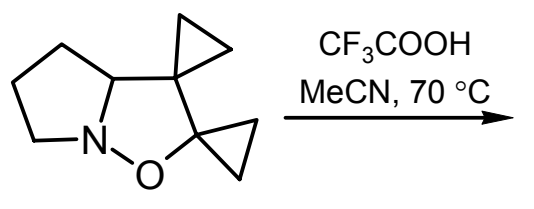

$18 \%$

70

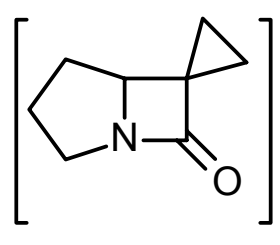

71<smiles>C[C@@H]1CCC(C2(C(=O)O)CC2)N1C(=O)C(F)(F)F</smiles>

72

Scheme 16. Rearrangement of $\mathbf{7 0}$ and ring-opening to $N$-protected $\beta$-amino acid $\mathbf{7 2}$.

The final product $\mathbf{7 2}$ is supposed to be formed through a carbapenem intermediate $\mathbf{7 1}$, that immediatly undergoes opening of the $\beta$-lactam ring, followed by acylation of the nitrogen atom with trifluoroacetate. An analogous reaction has previously been observed by Stoodley et al. for $\beta$-lactams fused to five-membered ring in the presence of trifluoracetic acid at room temperature. ${ }^{[52]}$ 


\section{New One-Pot Approach to 3-Spirocyclopropanated Monocyclic $\beta$-Lactams}

\subsection{Considerations}

Nitrone 44j, synthesized by condensation of formaldehyde $\mathbf{6 6}-\mathrm{H}$ with N-benzyl hydroxylamine hydrochloride $\mathbf{6 5} \mathbf{c} \cdot \mathbf{H C l}$ in the presence of a base, ${ }^{[46]}$ started decomposing during the isolation procedures (Scheme 12, Chapter 1).

Moreover, when $N$-(p-methoxybenzyl)-methyleneamine- $N$-oxide (44g) was subjected to 1,3 dipolar cycloaddition to bicyclopropylidene (24), the yield was just $21 \%$, while the results normally obtained in the cycloadditions of linear nitrones to $\mathbf{2 4}$ vary in the range between $\mathbf{7 5}$ and 100\% (Table 1, Chapter 1).

In order to get over the problems, which in the case of nitrones derived from formaldehyde 66- $\mathrm{H}$, are related with their instability, a different strategy was applied. The nitrones $\mathbf{4 4} \mathbf{g}$ and $\mathbf{4 4} \mathbf{j}$ were used in situ in the cycloaddition to the dipolarophile, like a more detailed literature research suggested. ${ }^{[53,54]}$ The generation of nitrones, by condensing a hydroxylamine $\mathbf{6 5} \cdot \mathbf{H X}$ and an aldehyde 66 (Scheme 10, Chapter 1), and their in situ addition to a dipolarophile has recently been applied in the synthesis of skeletal congeners of antitumor, antibiotic natural products. ${ }^{[55]}$ Nevertheless this method is used since longer, when the carbonyl derivative is particularly reactive, as in the case of formaldehyde. ${ }^{[54]}$

\subsection{Development of a Selective One-Pot Synthesis for 2-Azetidinones}

When the hydroxylamine $65 \mathrm{~d} \cdot(\mathbf{C O O H})_{2}$, formaldehyde $66-\mathrm{H}$ and the base sodium acetate were stirred in a sovirell glass with the dipolarophile $\mathbf{2 4}$ for 6 days at room temperature, a mixture of the expected cycloadduct 8-(p-methoxybenzyl)-7-oxa-8-aza-dispiro[2.0.2.3]nonane (47g) and surprisingly, of the relative $\beta$-lactam derivative 5-( $p$-methoxybenzyl)-5-azaspiro[2.3]hexan-4-one (53g) was obtained, in 8 and 22\% yield respectively, after purification by column cromatography (Scheme 17). 


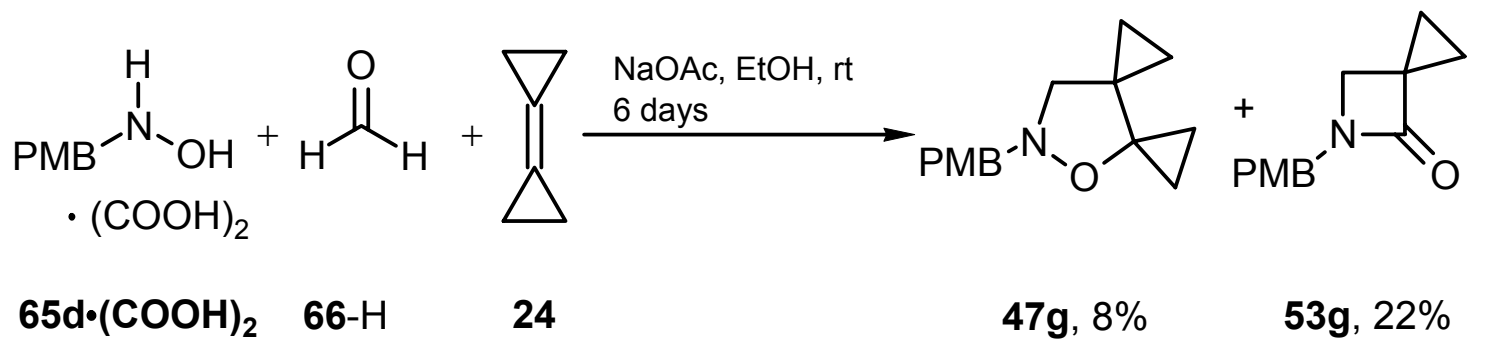

Scheme 17. Synthesis of $\mathbf{4 7} \mathbf{g}$ and $\mathbf{5 3 g}$, by BCP addition to the in situ generated nitrone $\mathbf{4 4 g}$.

Probably, the acidity furnished by the buffered system acetate/ ammonium gave the product $\mathbf{5 3 g}$, whose formation requires the rearrangement of $\mathbf{4 7} \mathrm{g}$ in the presence of acidic protons (Scheme 8, Chapter 1). To test the riproducibility of this result, further studies were conducted.

The experiment was repeated with benzylhydroxylamine hydrochloride $(\mathbf{6 5 c} \cdot \mathbf{H C l})$ and with the same aldehyde 66-H. 5-Benzyl-5-azaspiro[2.3]hexan-4-one 53j was obtained after 8 days at room temperature, in a comparable yield (25\%) with $\mathbf{5 3 g}$ but without any trace of the relative isoxazolidine (Scheme 18).

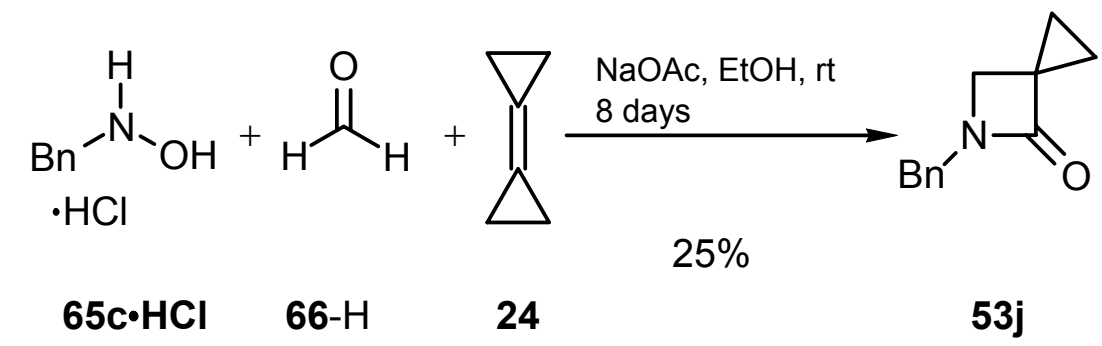

Scheme 18. Synthesis of $\mathbf{5 3} \mathbf{j}$, by BCP addition to the in situ generated nitrone $\mathbf{4 4 \mathbf { j }}$.

When the procedure was run at higher temperature $\left(45\right.$ or $\left.50^{\circ} \mathrm{C}\right)$ or at high pressure (10 Kbar), no significant improvement in yield were achieved, although the $\beta$-lactam was always the only isolated product (Table 4). No mixture with isoxazolidines, piperidones or other fragmentation products was observed. 


\begin{tabular}{|c|c|c|c|c|}
\hline Reagents & $\begin{array}{c}\text { Conditions } \\
\text { temp }\left[{ }^{\circ} \mathrm{C}\right] / \text { pressure }[\mathrm{KBar}]\end{array}$ & Time[d] & Product & Yield [\%] \\
\hline $\begin{array}{c}\mathbf{6 5 d} \cdot(\mathrm{COOH})_{2}(1 \mathrm{eq}), 24(1.5 \mathrm{eq}) \\
\mathrm{NaOAc}(1 \mathrm{eq}), 66-\mathrm{H}(1.5 \mathrm{eq})\end{array}$ & $45 / 1$ & 7 & $53 \mathrm{~g}$ & 30 \\
\hline $\begin{array}{l}\text { 65c·HCl (1 eq), } 24 \text { (1.5 eq) } \\
\mathrm{NaOAc}(1 \mathrm{eq}), \mathbf{6 6}-\mathrm{H}(1.5 \mathrm{eq})\end{array}$ & $50 / 1$ & 5 & $53 j$ & 33 \\
\hline $\begin{array}{c}\text { 65d }(\mathrm{COOH})_{2}(1 \mathrm{eq}), 24 \text { (2 eq) } \\
\mathrm{NaOAc}(1 \text { eq), 66-H (2 eq) }\end{array}$ & $25 / 10$ & 1 & $53 \mathrm{~g}$ & 28 \\
\hline $\begin{array}{l}\text { 65c·HCl (1 eq), } 24 \text { (2 eq) } \\
\mathrm{NaOAc} \mathrm{(1} \mathrm{eq),} \mathrm{66-H} \mathrm{(2} \mathrm{eq),}\end{array}$ & $25 / 10$ & 1 & $53 j$ & 22 \\
\hline
\end{tabular}

Table 4. Attempts to improve the selective one-pot synthesis of 2-azetidinones 53g and $53 \mathbf{j}$.

\subsection{Extension of the One-Pot 2-Azetidinone Synthesis to Different Substrates}

In view of the multiple beneficial effects of microwave heating on organic synthetic transformations reported in recent years, ${ }^{[56]}$ we tried out the possibility of reducing the reaction times by using microwaves. The main difference with the traditional sources of energy (oil and sand bath, heating mantles, etc) is that reactants and solvents are heated directly, without the vessel's interference. By the use of microwave technology, the energy is more efficiently used and the necessary amount of it is furnished in a faster and more homogeneous way.

After the first application in a laboratory in $1986,{ }^{[57]}$ and after the exhaustive treatments about interections between bodies and microwave-rays dued to Rippel ${ }^{[58]}$ and Mingos, ${ }^{[59]}$ modern single mode cavity ovens have been produced from several companies, with the achievement of high reproducibility and predictability in results.

The in situ 1,3-dipolar cycloaddition of the generated unstable and reactive nitrones ${ }^{[53]} \mathbf{4 4 9}$ and $\mathbf{4 4} \mathbf{j}$ to bicyclopropylidene (24) could be enhanced by the use of microwave technology in terms of velocity and yields. 
For this reason several different conditions were tried. In particular, the stechiometry was changed and the reaction temperature increased, this last parameter allowing a shorter reaction time.

The hydroxylamines salt $\mathbf{6 5 d} \cdot(\mathbf{C O O H})_{2}$ and $\mathbf{6 5 c} \cdot \mathbf{H C l}$ gave the desired products in better yields in comparison to the previously used methods (Scheme 17 and 18 and Table 4), and in much less time (from 6 days to 45 minutes for $\mathbf{5 3 g}$ and from 8 days to 60 minutes for $\mathbf{5 3 \mathbf { j }}$ ) (Table 5).

\begin{tabular}{|c|c|c|c|c|}
\hline Reagents & $\begin{array}{c}\text { Temperature } \\
{\left[{ }^{\circ} \mathrm{C}\right]}\end{array}$ & Time[min] & Product & Yield[\%] \\
\hline \multicolumn{5}{|l|}{ 65d•(COOH $)_{2}(1 \mathrm{eq}), 24(2 \mathrm{eq})$} \\
\hline $\mathrm{NaOAc}(1 \mathrm{eq}), 66-\mathrm{H}(2 \mathrm{eq})$ & 60 & 60 & $53 \mathrm{~g}$ & 26 \\
\hline \multicolumn{5}{|l|}{$65 \mathrm{~d} \cdot(\mathrm{COOH})_{2}(2 \mathrm{eq}), 24(1 \mathrm{eq})$} \\
\hline $\mathrm{NaOAc}(2 \mathrm{eq}), 66-\mathrm{H}(2 \mathrm{eq})$ & 80 & 45 & $53 g$ & $53^{[a]}$ \\
\hline 65c·HCl (1 eq), 24 (2 eq) & 60 & 195 & $53 \mathbf{j}$ & 34 \\
\hline \multicolumn{5}{|l|}{$\mathrm{NaOAc}(1 \mathrm{eq}), 66-\mathrm{H}$ (2 eq) } \\
\hline \multicolumn{5}{|l|}{ 65c·HCl (1 eq), 24 (2 eq) } \\
\hline $\mathrm{NaOAc}(1 \mathrm{eq}), 66-\mathrm{H}(2 \mathrm{eq})$ & 100 & 60 & $53 j$ & 48 \\
\hline \multicolumn{5}{|l|}{ 65c·HCl (2 eq), 24 (1 eq) } \\
\hline $\mathrm{NaOAc}(2 \mathrm{eq}), 66-\mathrm{H}(2 \mathrm{eq})$ & 100 & 60 & $53 j$ & $68^{[a]}$ \\
\hline
\end{tabular}

Table 5. Attempts to increase the microwave assisted one-pot synthesis of 2azetidinones $\mathbf{5 3} \mathbf{g}$ and $\mathbf{5 3} \mathbf{j}$.

The best results were obtained using a twofold excess of hydroxylamine salt $\mathbf{6 5}$, of formaldehyde 66- $\mathrm{H}$ and of sodium acetate respect to the olefine 24. Using microwaves, 2azetidinone $53 \mathrm{~g}$ was thus obtained in $53 \%$ yield, instead of $30 \%$, running the reaction at $80{ }^{\circ} \mathrm{C}$ for $45 \mathrm{~min}$, instead of 7 days (see Table 4) and compound $\mathbf{5 3 \mathbf { j }}$ was obtained in $68 \%$ yield, running the reaction at $100{ }^{\circ} \mathrm{C}$ for $60 \mathrm{~min}$ (without microwaves the yield was $33 \%$ after 5 days) (see Table 4). It is noteworthy that hydroxylamines $\mathbf{6 5}$, formaldehyde $\mathbf{6 6}-\mathrm{H}$, and 
sodium acetate are used in excess, but they are cheaper, and often commercially available, while bicyclopropylidene (24) needs more complex steps to be prepared. ${ }^{[18]}$

The next step was to prove the generality of the new process for preparing 3-spirocyclopropanated-2-azetidinones in a single step. The reactions were performed in sealed vessels for the microwave system from Personal Chemistry. The reaction volumes were never bigger than $5 \mathrm{~mL}$ and high concentrations $(0.75$ to $2.5 \mathrm{M})$ of reactants were used to accelerate the cycloaddition step. The solid starting materials were usually not completely solved. The reaction controls were performed with NMR measurments because the limiting reagent (the olefine) is volatile and cannot be observed on TLC. Once found the right conditions, the reaction was repeated to determine the yield.

Several different hydroxylamines 65 and carbonyl compounds 66, 73-76 were heated under microwave irradiation in the presence of $\mathbf{2 4}$ (see Experimental Part, General Notes).

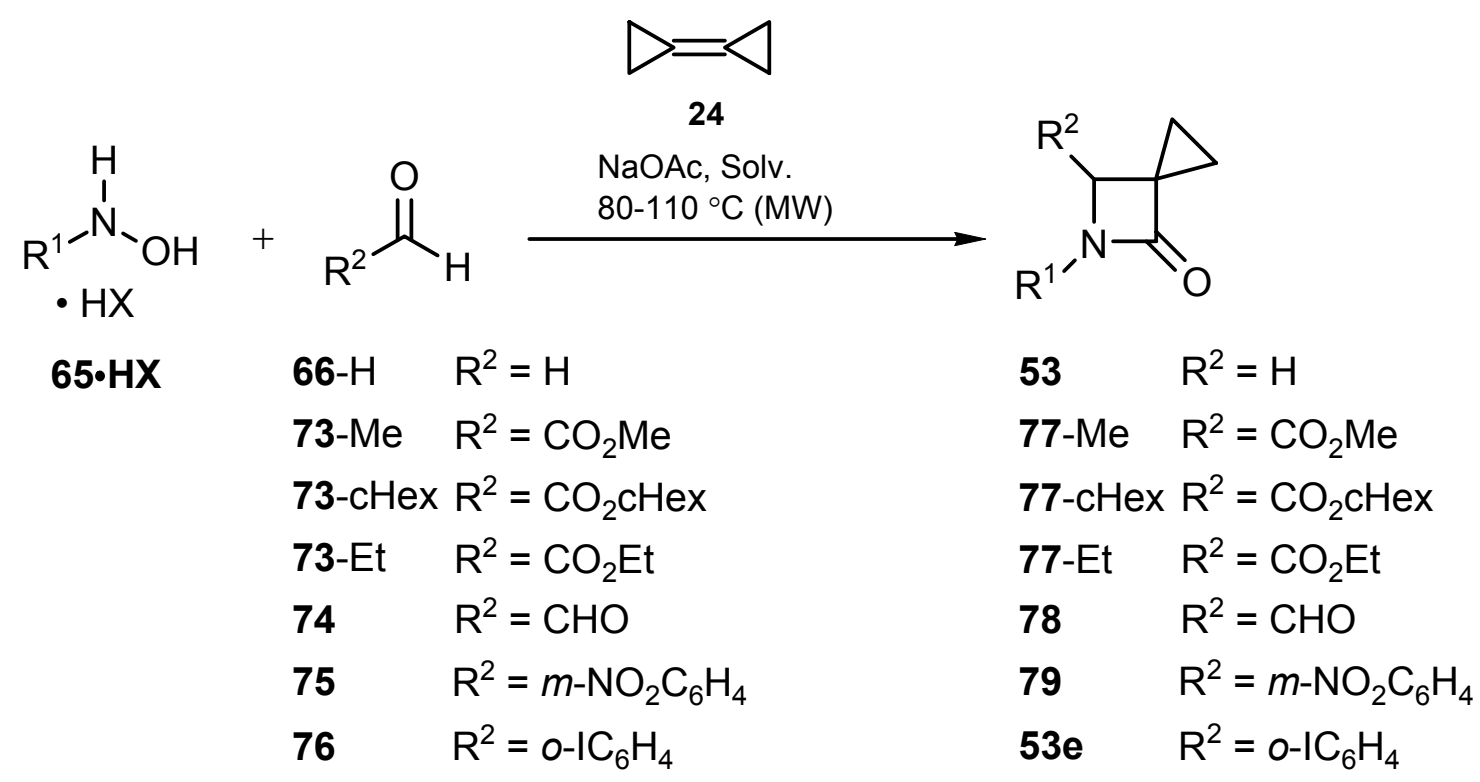

Scheme 19. One-Pot three component synthesis of 3-spirocyclopropanated-2-azetidinones under microwave heating.

The hydroxylamine salts $\mathbf{6 5 c}$, $\mathbf{f}$, and $\mathbf{g}$ are commercially available, while $\mathbf{6 5 d} \mathbf{d}, \mathbf{e}, \mathbf{h}, \mathbf{i}$ were prepared following known procedures. ${ }^{[43,60]} N$-Monosubstituted hydroxylamines are sold and isolated like salts, because of their low stability in the free form (Table 6). 


\begin{tabular}{ccc}
\hline $\mathbf{6 5}$ & $\mathrm{R}^{1}$ & $\mathrm{HX}$ \\
\hline $\mathbf{c}$ & $\mathrm{Bn}$ & $\mathrm{HCl}$ \\
$\mathbf{d}$ & $\mathrm{PMB}$ & $(\mathrm{COOH})_{2}$ \\
$\mathbf{e}$ & $\mathrm{Bnh}$ & $\mathrm{HCl}$ \\
$\mathbf{f}$ & $\mathrm{tBu}$ & $\mathrm{HCl}$ \\
$\mathbf{g}$ & $\mathrm{Me}$ & $\mathrm{HCl}$ \\
$\mathbf{h}$ & $\mathrm{Ph}$ & $\mathrm{HCl}$ \\
$\mathbf{i}$ & $p \mathrm{BrC}_{6} \mathrm{H}_{4}$ & $\mathrm{HCl}$ \\
\hline
\end{tabular}<smiles>[R]CN[R]</smiles>

65

$\mathrm{Bnh}=\mathrm{CH}(\mathrm{Ph})_{2}$

$\mathrm{PMB}=\mathrm{CH}_{2} \longrightarrow \mathrm{OMe}$

Table 6. Hydroxylamines used in the one-pot process for the synthesis of $\beta$-lactams.

Azaspiro[2.3] hexanones 53g,j and 53e,f-H were obtained in yields ranging from 49 to $73 \%$, with formaldehyde 66-H (a titrated solution of formaline was used) ${ }^{[61]}$ and changing the nature of the hydroxylamine $\mathbf{6 5} \cdot \mathbf{H X}$ (Table 7, Entry 1-4).

In the case of 53j and 53e-H also paraformaldehyde was used, but lower yields were obtained in comparison with the stabilized solution of the monomer in water: respectively 56 and $37 \%$, instead of 68 and 49\% (Table 7, Entry 1 and 3).

The use of glyoxylates 73-Me and 73-Et gave also good results. The pure methyl derivative 73-Me ${ }^{[62]}$ gave 77d-Me in 78\% yield (Table 7, Entry 7). Ethyl glyoxylate 73-Et was used as a commercially available solution in toluene. The latter did not interfere with the reaction course, that led to the desired products $77 \mathbf{c}-$ Et in $72 \%$ yield and $77 \mathbf{f}-$ Et in $53 \%$ yield (Table 7 , Entry 5 and 6).

\begin{tabular}{cccccccc}
\hline Entry & Start. Mat. & $\mathrm{R}^{1}$ & $\mathrm{R}^{2}$ & Time [min] & Temp [ $\left.{ }^{\circ} \mathrm{C}\right]$ & Prod. & Yield[\%] \\
\hline 1 & $\mathbf{6 5 d}+\mathbf{6 6 - H}$ & $\mathrm{PMB}$ & $\mathrm{H}$ & 45 & 80 & $\mathbf{5 3 g}$ & 53 \\
2 & $\mathbf{6 5 c}+\mathbf{6 6 - H}$ & $\mathrm{Bn}$ & $\mathrm{H}$ & 60 & 100 & $\mathbf{5 3 j}$ & 68 \\
3 & $\mathbf{6 5 e}+\mathbf{6 6 - H}$ & $\mathrm{Bnh}$ & $\mathrm{H}$ & 30 & 100 & $\mathbf{5 3 e - H}$ & 49 \\
4 & $\mathbf{6 5 f}+\mathbf{6 6 - H}$ & $t \mathrm{Bu}$ & $\mathrm{H}$ & 30 & 80 & $\mathbf{5 3 f - H}$ & $\mathbf{7 3}$ \\
5 & $\mathbf{6 5 c}+\mathbf{7 3 - E t}$ & $\mathrm{Bn}$ & $\mathrm{CO}_{2} \mathrm{Et}$ & 15 & 80 & $\mathbf{7 7 c}-\mathrm{Et}$ & $\mathbf{7 2}$ \\
6 & $\mathbf{6 5 f}+\mathbf{7 3 - E t}$ & $t \mathrm{Bu}$ & $\mathrm{CO}_{2} \mathrm{Et}$ & 105 & 80 & $\mathbf{7 7 f - E t}$ & 53 \\
7 & $\mathbf{6 5 d}+\mathbf{7 3 - M e}$ & $\mathrm{PMB}$ & $\mathrm{CO}_{2} \mathrm{Me}$ & 120 & 80 & $\mathbf{7 7 d - M e}$ & $\mathbf{7 8}$ \\
\hline
\end{tabular}

Table 7. One-pot three-component reaction under microwave heating for the direct conversion of $\mathbf{6 5}$, carbonyl derivatives and bicyclopropylidene (24) to 3-spirocyclopropanated 2-azetidinones 53 (see Scheme 19). 
In this last case, the yield was lower because side products were found: some unreacted isoxazolidine $\mathbf{4 7 f - E t}$ and the thermal rearrangement product 5-tert-butyl-8-oxo-5-azaspiro[2.5] octane-4-carboxylate 49f-Et (Figure 16). Changing the conditions to lower temperature and longer reaction time did not avoid the formation of these side products. Probably, the bulk of the tertbutyl group creates hinderance and makes the nitrogen protonation not so easy like with other $N$-protecting groups.

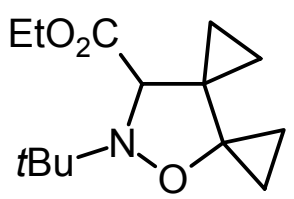

47f-Et

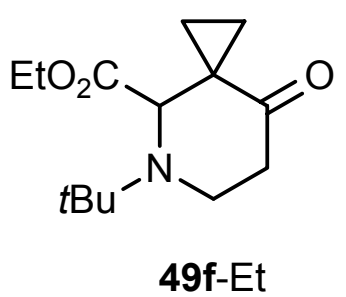

49f-Et

Figure 16. Side products in the reaction of ethyl glyoxylate 73-Et and tertbutylhydroxylamine $\mathbf{6 5 f} \cdot \mathbf{H C l}$.

The very good results obtained with the hydroxylamines $\mathbf{6 5 c - f}$ were not repeated with $\mathbf{6 5 g}-\mathbf{i}$. With $\mathrm{N}$-methylhydroxylamine hydrochloride, formaldehyde $(\mathbf{6 6}-\mathrm{H})$ and $\mathbf{2 4}$, the yield of the corresponding $\mathrm{N}$-methylazetidinone $\mathbf{5 3 g}-\mathrm{H}$ was at best $10 \%$ and using the same hydroxylamine derivative with ethyl glyoxylate (73-Et) and $\mathbf{2 4}$, the corresponding azetidinone $\mathbf{7 7 g}$-Et could not be detected even in the crude reaction mixture (Scheme 20).
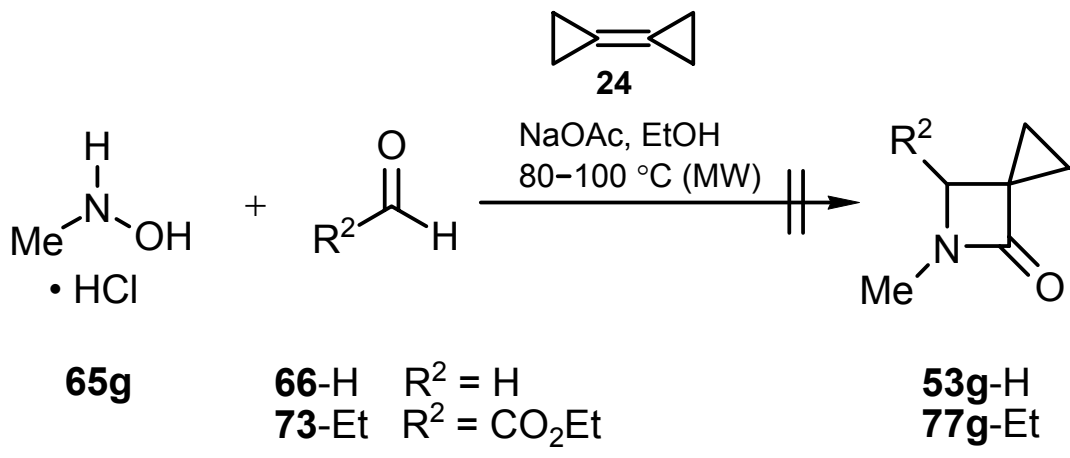

Scheme 20. Methyl hydroxylamine hydrochloride $65 \mathrm{~g} \cdot \mathbf{H C l}$ reactions.

The particularly reactive methyl nitrone, formed in the first step of the cascade, is probably involved in further equilibria with water or with the hydroxylamine itself, like reported in a work of Fornefeld, ${ }^{[54 \mathrm{~b}]}$ so that the compond $\mathbf{5 3} \mathbf{g}-\mathrm{H}$ was found just in traces.

When $N$-aryl hydroxylamines $\mathbf{6 5 h}$ and $\mathbf{6 5 i}$ were heated in the microwave oven with formaldehyde 66- $\mathrm{H}$ in ethanol under different conditions, the reaction control via NMR 
spectrometry never presented signals, which could be assigned to defined structures and also attempts to solve the mixture by column cromatography failed (Scheme 21).

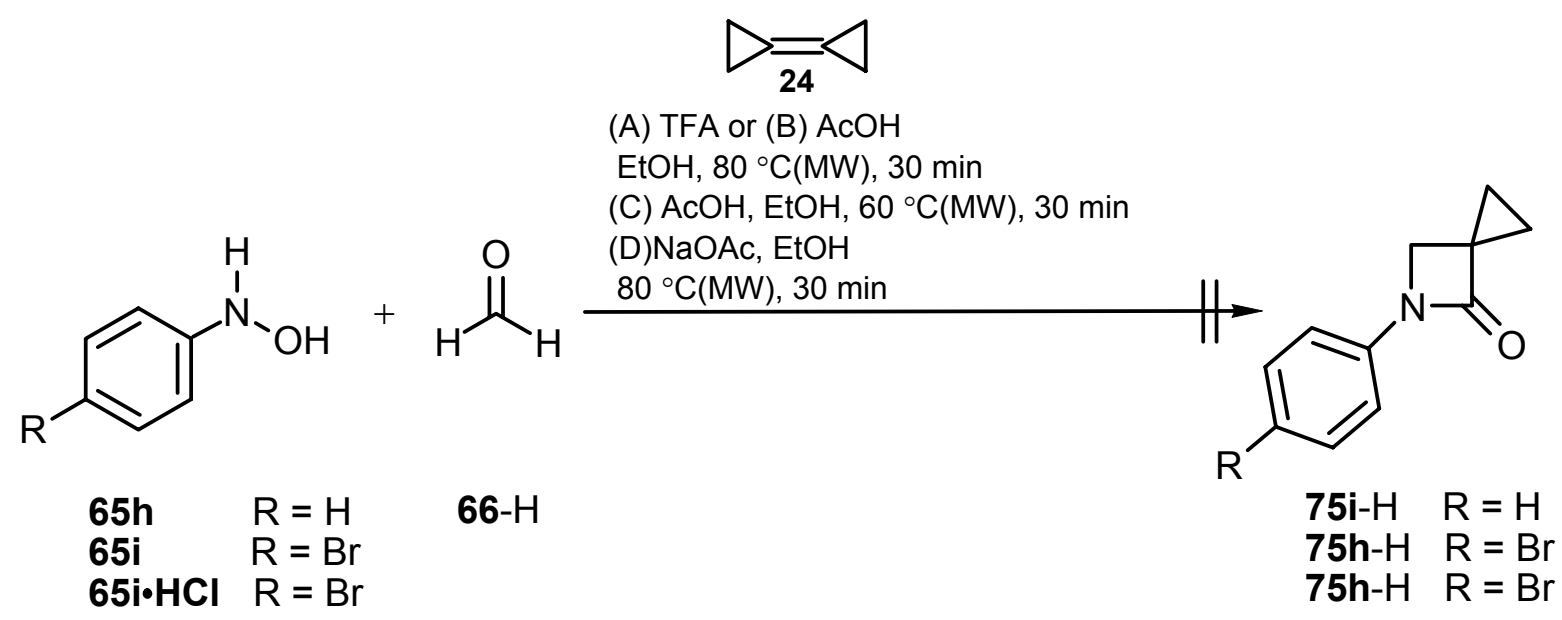

Scheme 21. Attempts of preparation of $N$-aryl substituted $\beta$-lactams $\mathbf{7 5 h}, \mathbf{i}-\mathrm{H}$.

Bicyclopropylidene (24) has already been added to nitrones $44 \mathbf{k}$, derived from $\mathrm{N}$-aryl hydroxylamines, but the cycloadduct $47 \mathbf{k}$ has never been isolated. The mixture of 24 and $44 k$ has been heated at high temperature to isolate the thermal rearrangement products $49 \mathrm{k}$ and $\mathbf{8 0}$ (Scheme 22). ${ }^{[32 \mathrm{~b}]}$
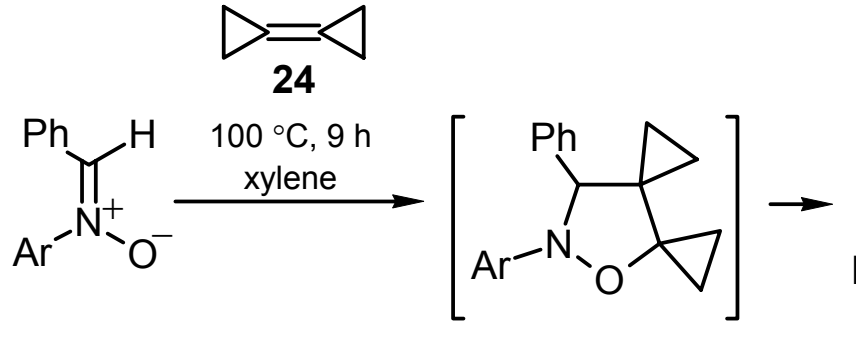

44k

$47 k$<smiles>[X]C1=CCN([Ga])C(c2ccccc2)C12CC2</smiles>

49k<smiles>[X]c1ccc2c(c1)CCC(=O)C1(CC1)C(c1ccccc1)N2</smiles>

80

Scheme 22. 1,3-Dipolar cycloaddition of $N$-aryl nitrones $44 \mathrm{k}$ to BCP (24).

Isoxazolidines of type $\mathbf{8 3}$ have already been isolated from the cycloaddition of nitrones $44 \mathbf{k}$ to alkylidenecyclopropane 82, but their thermal rearrangement under acidic conditions for the synthesis of $N$-aryl substituted $\beta$-lactams of type $\mathbf{8 4}$ has never been tried (Scheme 23). ${ }^{[63]}$ 


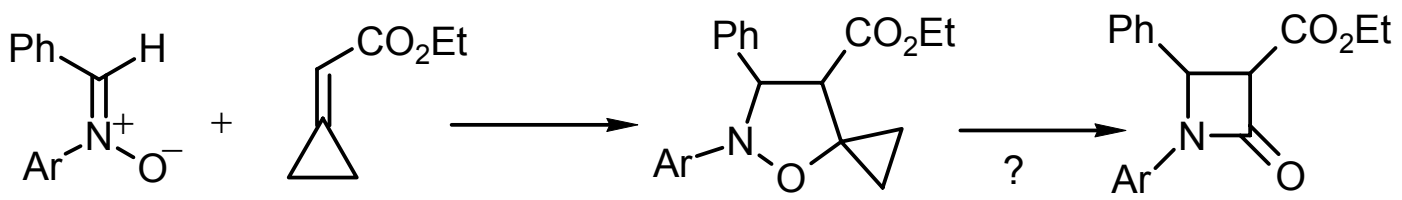

$44 k$ 82

83

84

Scheme 23. 1,3-Dipolar cycloaddition to 82 and the never tried rearrangement to 84 under traditional heating in the presence of acid.

It can be supposed that the electron pair on the nitrogen atom in isoxazolidines $47 \mathbf{k}$ is too much influenced by the aromatic ring, to be prone to protonation, and this can be the reason for the unsuccessful attempts of synthesis under the one-pot microwave-assisted process (Scheme 21).

Moreover $N$-aryl hydroxylamines are known to be particularly sensitive materials. ${ }^{[64]}$ They are susceptible toward oxidation, particularly in the presence of a base, and are also prone toward redox disproportionation reaction: ionic or zerovalent metals can catalyze the formation of nitrosobenzene and aniline derivatives, starting from $35{ }^{\circ} \mathrm{C}$. Impurities deriving from zerovalent metals are impossible to avoid because these are necessary for the synthesis. ${ }^{[64 a]}$ Even acidic conditions can damage $\mathrm{N}$-aryl hydroxylamine, that can in this conditions rearrange to aminophenol, when not para-substituted. ${ }^{[64 \mathrm{~b}]}$

From the complex mixtures obtained after the microwave experiments and their work-up, it was very hard to distinguish if there were a particular problematic step, within the requested ones for the one-pot procedure, or if the hydroxylamines themselves decomposed, under one of the possible suggested processes, eventually catalyzed from the microwave irradiation.

In order to extend to different substrates the discovered microwave assisted process for the synthesis of $\beta$-lactams, were tried also the activated carbonyl derivatives 73-cHex and 74, 75, 76.

Glyoxale 74 gave no positive results and the symmetrical expected product 78 was not recovered after column cromatography of the crude mixture obtained by heating $65 \mathrm{c} \cdot \mathbf{H C l}, 74$ and sodium acetate, under microwave irradiation (Scheme 24). 


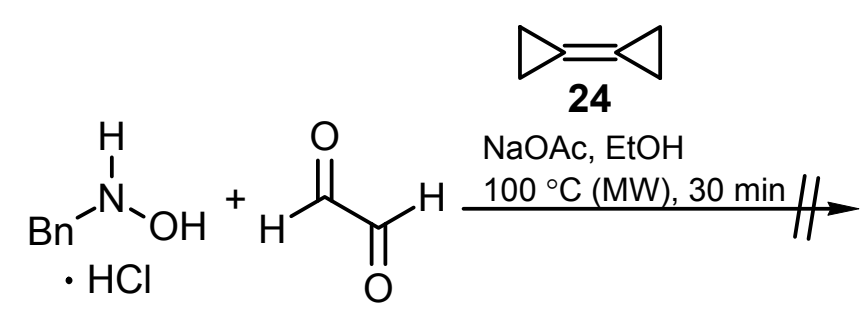

$65 \mathrm{c} \cdot \mathrm{HCl}$

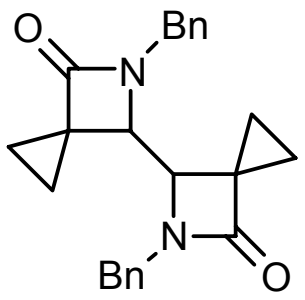

78

Scheme 24. Failed attempt to follow the one-pot microwave assisted procedure with glyoxale 74 .

The hydroxylamine $\mathbf{6 5} \mathbf{c} \cdot \mathbf{H C l}$ and the benzaldehyde $\mathbf{7 5}$, heated in the microwave system for $165 \mathrm{~min}$ at $80{ }^{\circ} \mathrm{C}$, gave as final product just the cycloadduct 81 in $70 \%$ yield (Scheme 25), while no trace of the azetidinone $\mathbf{7 9}$ was detected (Scheme 19).

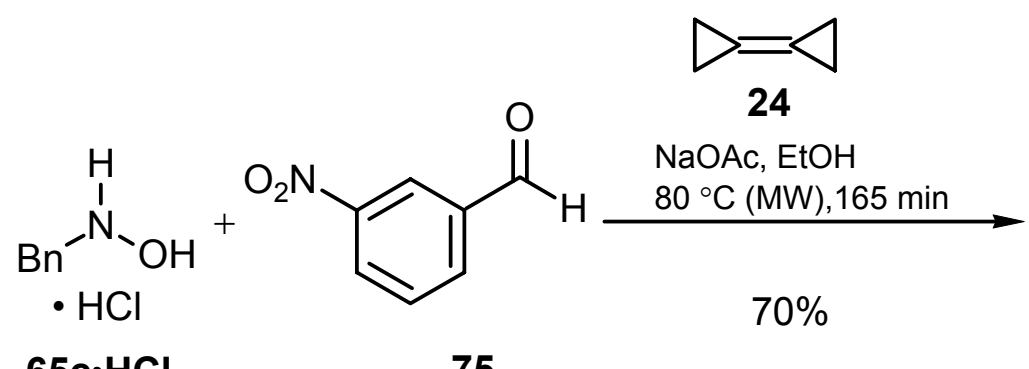

75

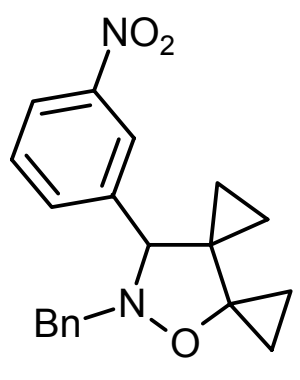

81

Scheme 25. Synthesis of the adduct 81 under microwave heating.

It's well known that the cycloaddition of $C$-aryl-nitrones to bicyclopropylidene are particularly slow and probably this step restrained the intire process. ${ }^{[65]}$

A higher temperature was tried, with the aim to accelerate the cycloaddition step, but a mixture of cycloadduct $\mathbf{8 1}$ and piperidone $\mathbf{8 5}$, respectively in $27 \%$ and $40 \%$ yield, was obtained after column cromatography (Scheme 25). 


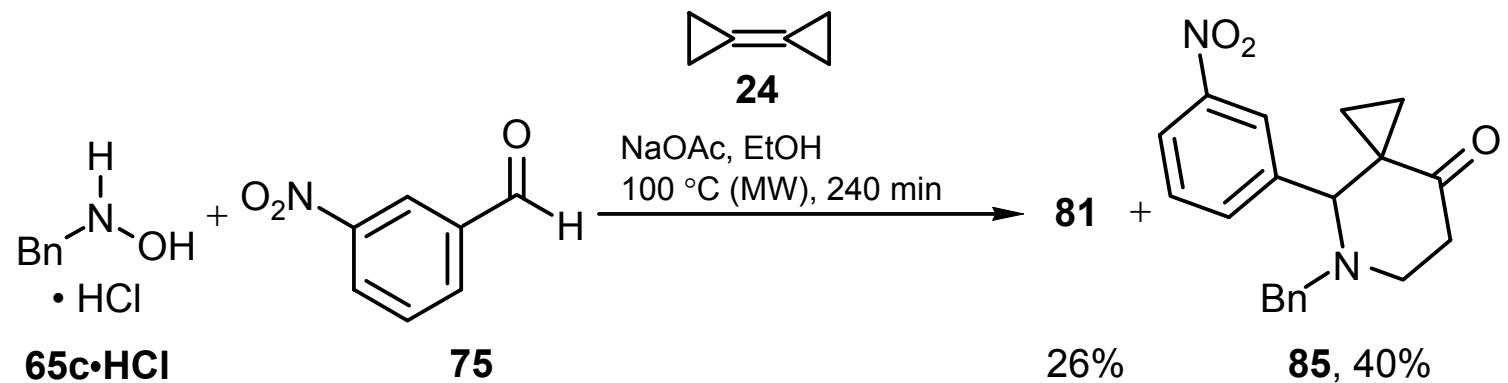

Scheme 26. Partial thermal rearrangement to 85 .

When the strong trifluoacetic acid (TFA) was introduced as the source of protons in the mixture of free hydroxylamine and carbonyl derivative in $o$-xylene, heating at $110{ }^{\circ} \mathrm{C}$, the desired azetidinones 53e and 77c-cHex were isolated in 18 and 30\% yield, respectively. The aldehyde 76 needed 2 hours, while the more activated glyoxylate $73-\mathrm{cHex}^{[62]}$ led to the final product in just half that time (Scheme 27).
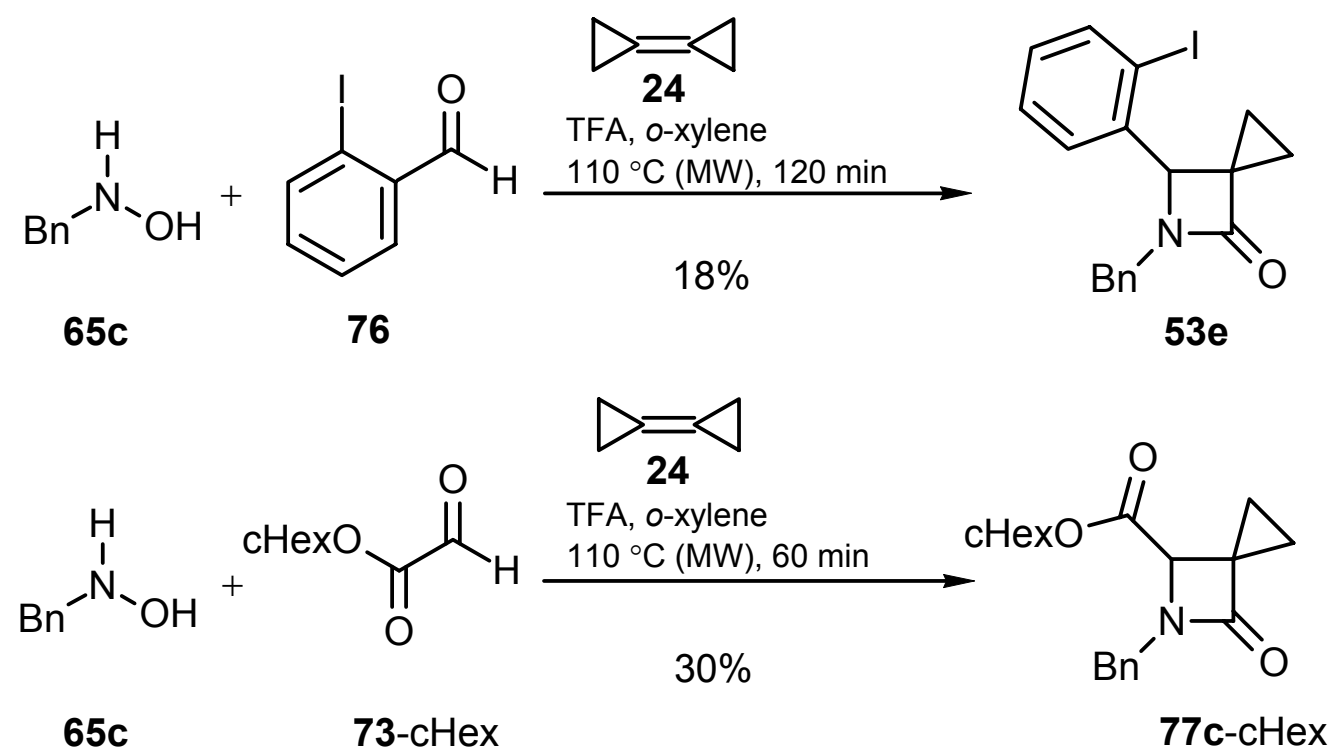

Scheme 27. Microwave assisted approach to $\beta$-lactams 53e and 77c-cHex.

When methylenecyclopropane (43) ${ }^{[18]}$ was employed as dipolarophile in this three-component reaction with $65 \mathrm{c} \cdot \mathbf{H C l}$ and formaldehyde $(66-\mathrm{H})$, the expected product 86 was isolated in only 9\% yield along with 4 -spirocyclopropaneisoxazolidine (87), which was formed along with the fragmented 5-spirocyclopropanated regioisomer, and cannot undergo acid-catalyzed fragmentative rearrangement (Scheme 28). 


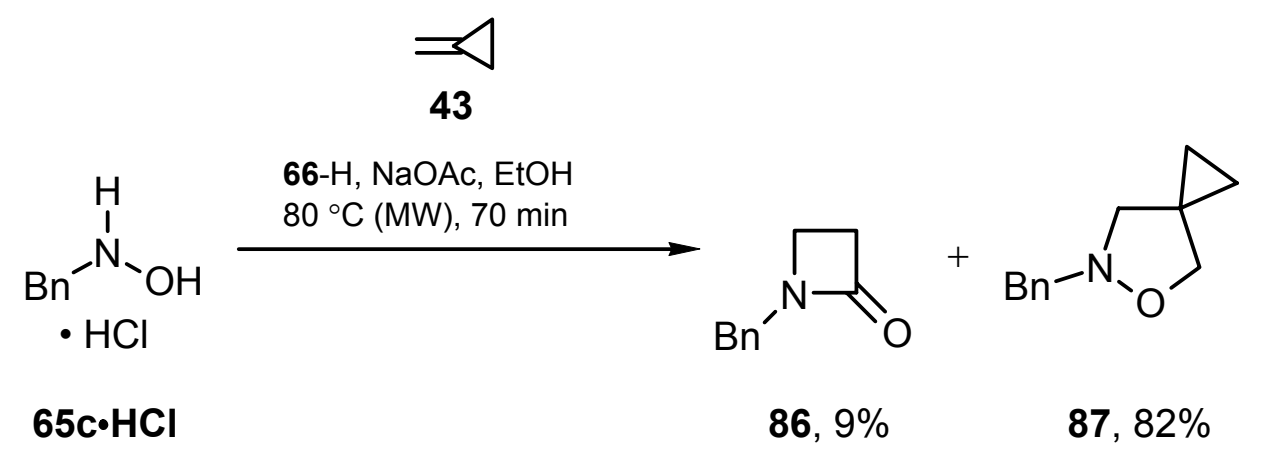

Scheme 28. One-pot three-component reaction under microwave heating starting from methylencyclopropane $\mathbf{4 3}$.

The identification of the end of the process was particularly treaky, because compound $\mathbf{8 7}$ as well as its 5-spiro-regioisomer show rotamers in the NMR spectra, the alkyl signals of which are broad and overlapping. Just after isolating the mixture of regioisomers and measuring a spectrum at $100{ }^{\circ} \mathrm{C}$, was possible to identify the single signals and to repeat the reaction with the comprehension of its course.

Theorethically, under this strategy could also be synthethyzed 2-azetidinones 89, lacking in the spirocyclopropane. The synthesis of such derivatives can nevertheless be achieved by different methodologies, that don't need expensive starting material like the alkylidenecyclopropanes 88 (Scheme 29).

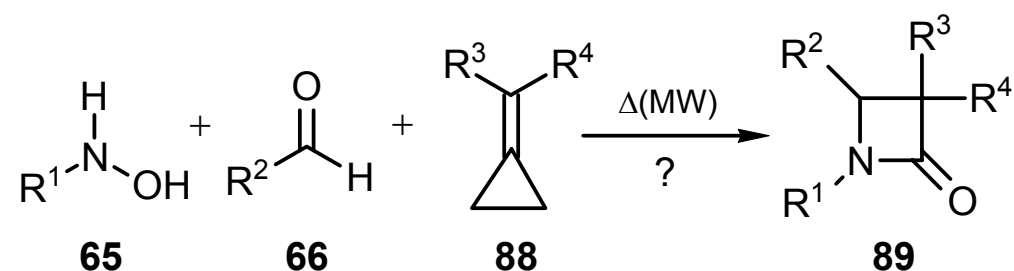

Scheme 29. Possible synthesis under microwave assisted one-pot process of general $\beta$ lactams 89.

\subsection{Conclusions about the newly developed one-pot reaction}

Because of the wide-ranging significance of $\beta$-lactams, the development of efficient methods for their synthesis is an important objective. The synthesis just proposed (Scheme 19) can furnish monocyclic $\beta$-lactam derivatives in one step, by using microwave irradiation and short 
times, starting in most cases from commercially available reagents (hydroxylamine $\mathbf{6 5}$ and carbonyl derivatives 66), except the alkylidenecyclopropane 88. Using bicyclopropylidene 24, spirocyclopropanated derivatives $\mathbf{5 3}$ and $\mathbf{7 7}$ can be prepared.

Using as energy source the microwave heating, a cascade of reactions takes place in a well defined sequence, so that it is possible to name it a multicomponent process. ${ }^{[66]}$

Apparently, the nitrone initially formed from the aldehyde (66) and the hydroxylamine (65), undergo $\mathbf{1 , 3 - d i p o l a r}$ cycloaddition to $\mathbf{2 4}$, and the resulting isoxazolidine $\mathbf{4 7}$, under the slightly acidic conditions of the hydroxylamine hydrochloride/sodium acetate buffered system

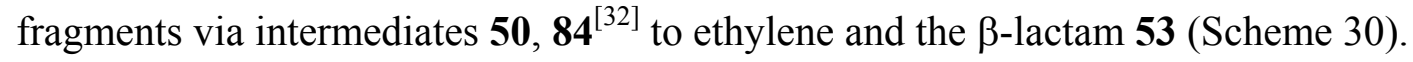

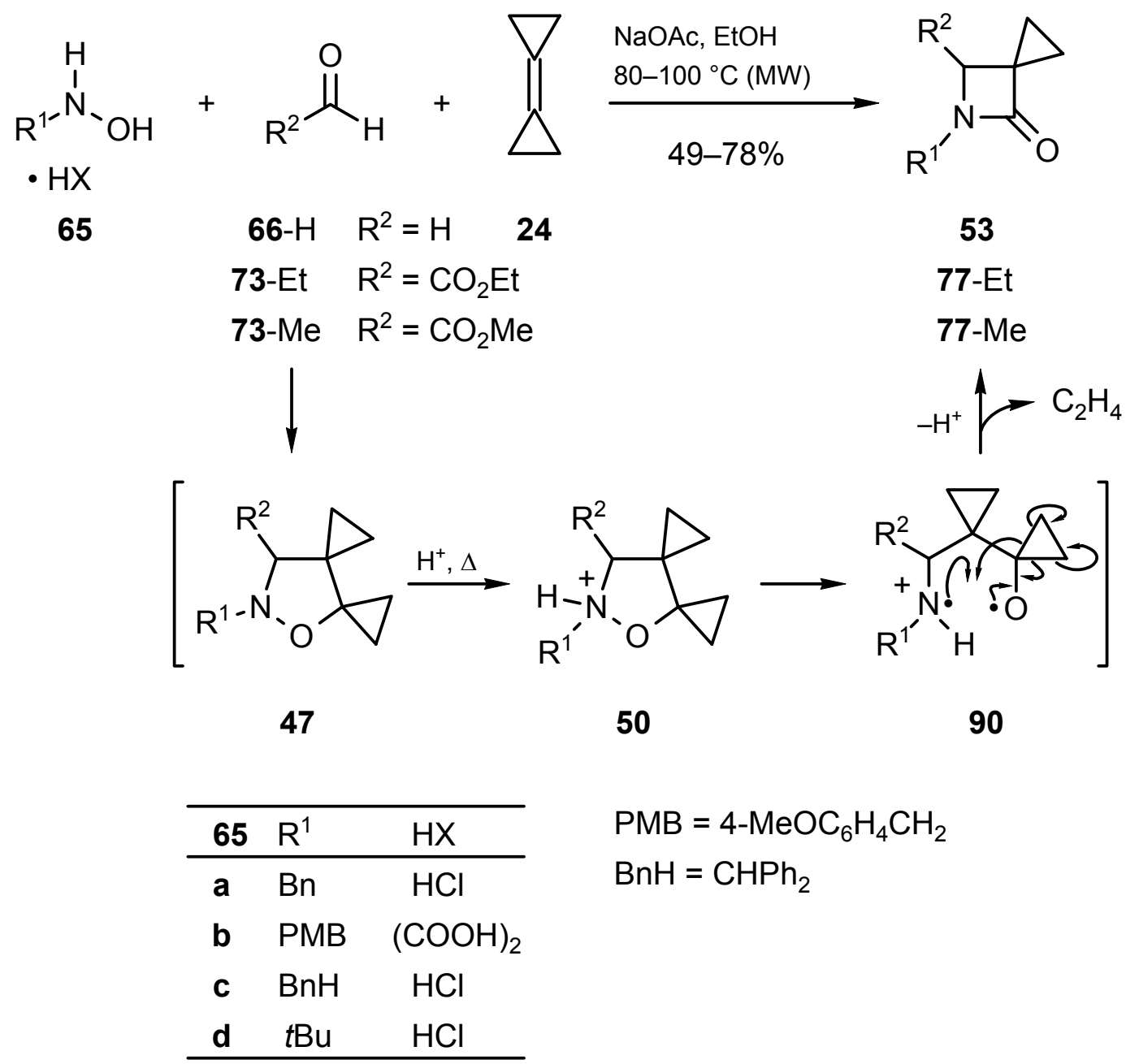

Scheme 30. One-pot three-component reaction under microwave heating for the direct conversion of alkylhydroxylamine hydrochlorides 65, aldehydes 66-73 and bicyclopropylidene (24) to 3-spirocyclopropanated 2-azetidinones $\mathbf{5 3}$ and $\mathbf{7 7}$. 
The fragmentative rearrangement of 5-spirocyclopropanated isoxazolidines 46 and 47 previously had been carried out with reasonably strong acids such as trifluoroacetic, $p$ toluenesulfonic or hydrochloric acid, like shown in the previous chapter (Scheme 15). To better understand, why this new one-pot three-component reaction worked without any of these strong free acids present, control experiments were carried out with the isolated dispirocyclopropanated 47c-Et. When the latter compound was heated with added acetic acid in acetonitrile at $70{ }^{\circ} \mathrm{C}$ overnight, none of the azetidinone $77 \mathbf{c}$-Et was detected, but heating 47c-Et under the same conditions with benzylhydroxylamine hydrochloride $\mathbf{6 5 c} \cdot \mathbf{H C l}$ did furnish 77c-Et (59\%). For the overall transformation to occur, the added sodium acetate is essential as well. An experiment with all the components for the formation of 77c-Et, except for the added sodium acetate, carried out in the microwave oven, gave no trace of product. In fact, not even the condensation of the hydroxylamine and the aldehyde to the nitrone took place.

Since this one-pot three-component reaction has no precedent, it is difficult to estimate the role of the microwave heating. In any case, it is remarkable that the time required for the overall reaction is never longer than 2 hours, whereas with traditional heating at $45{ }^{\circ} \mathrm{C}$ the 1,3-dipolar cycloaddition of the most reactive $N$-methyl-C-(ethoxycarbonyl)nitrone onto bicyclopropylidene (24) requires $16 \mathrm{~d}$, and at higher temperatures only the corresponding spirocyclopropanated piperidone derivative is formed. ${ }^{[50]}$ 


\section{Microwave Heating to Accelerate the 1,3-Dipolar Cycloadditions of Nitrones to Bicyclopropylidene}

\subsection{Considerations}

The synthetical methodology based on the nitrone cycloaddition to methylenecyclopropane (43) or bicyclopropilydene (24), followed by thermal rearrangement of the resulting adducts to give functionalized pyridones (Scheme 6, Chapter 1) has already been demonstrated as a versatile strategy to obtain alkaloids like for example $\mathbf{9 1}$ and $\mathbf{9 2}$, or different azaheterocycles like the rare amino acid 93 (Figure 17). ${ }^{[32 \mathrm{a}]}$<smiles>OC1CN2CCCC[C@H]2[C@H]1O</smiles>

$91(+)$-lentiginosine<smiles>OCC1CCCN2CCCCC12</smiles>

92 ( \pm )-epilupinine<smiles>O=C1CCNC(C(=O)O)C1</smiles>

93 (2S)-4-oxopipecolic acid

Figure 17. Different natural compounds obtained with the thermal rearrangement of 5spirocyclopropanated isoxazolidines.

With the same strategy were also prepared biologically active compounds able to cleave a supercoiled DNA plasmid, ${ }^{[67]}$ for their structural analogy with naturally occurring cytotoxic compounds, like illudines 94 and ptaquiloside 95 (Figure 18).<smiles>[R]C[C@]1(C)C=C2C(=O)[C@](C)(O)C3(CC3)C(C)=C2[C@H]1O</smiles>

94-OH Illudine $\mathrm{S}(\mathrm{R}=\mathrm{OH})$ 94- $\mathrm{H} \quad$ Illudine $\mathrm{M}(\mathrm{R}=\mathrm{H})$

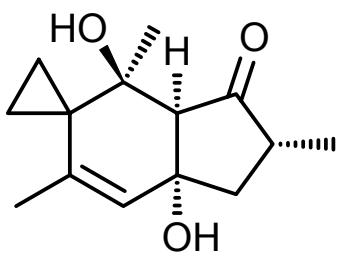

95 Ptaquiloside

Figure 18. Spirocyclopropanated citotoxic, naturally occurring compounds.

Quite a large number of $\beta$-lactams in the spirocyclopropanated form has been prepared, applying the rearrangement under acidic conditions of BCP-derived cycloadducts 47 (Scheme 18, Chapter 1) and that preparation was accelerated and simplified to one-step with 
the development of the one-pot microwave assisted synthesis (Scheme 19, Chapter 2). Moreover, it would be interesting to show if it is possible to obtain indipendentely not only the $\beta$-lactams 53 but also the isoxazolidine-cycloadducts 46 and 47 or the piperidones 48 and 49, starting from the same three components olefine, hydroxylamine and carbonyl derivative (Scheme 31). In that case it would be possible the selective synthesis of three different azaheterocycle with the same starting materials, just changing the reaction conditions.

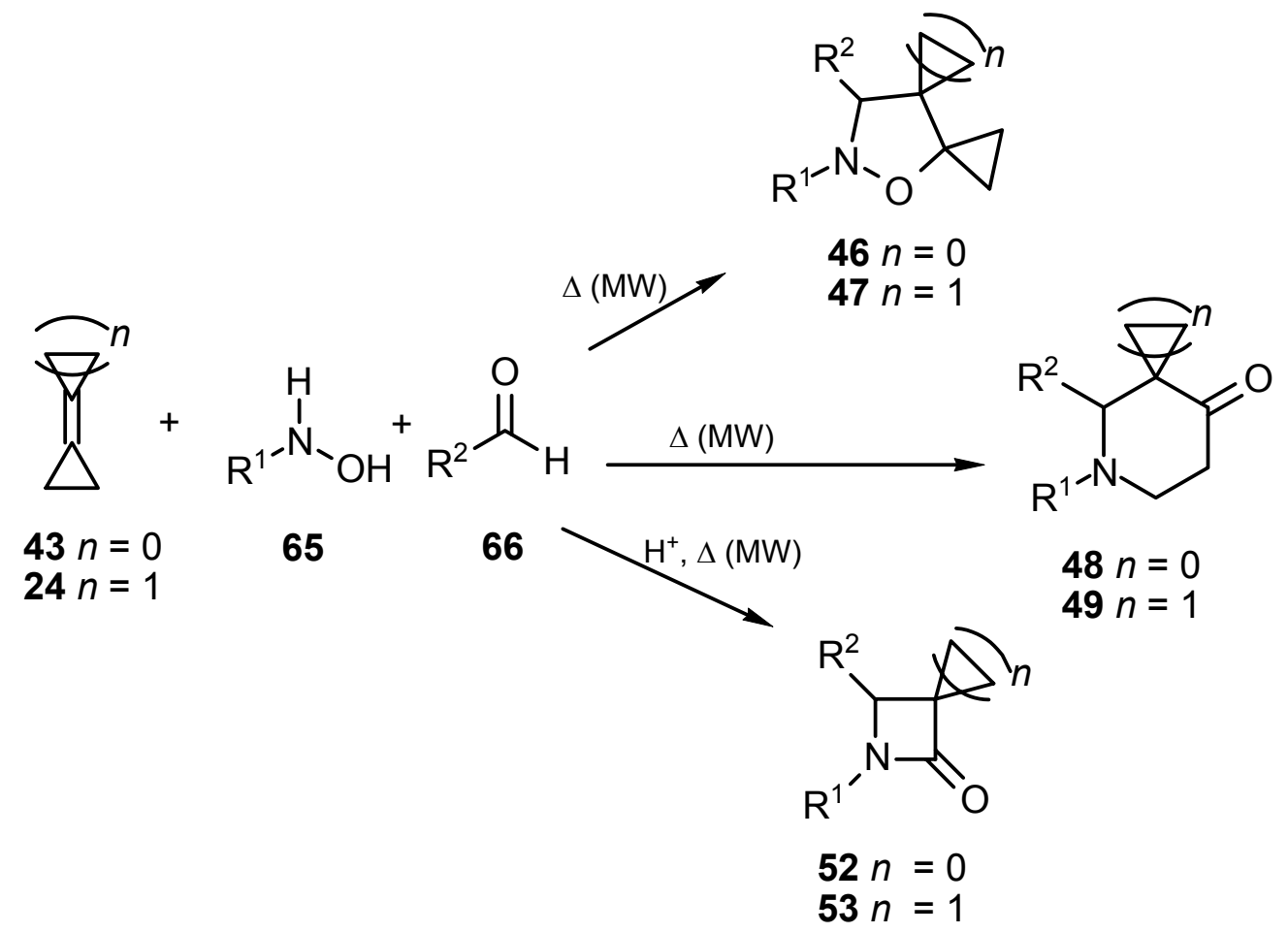

Scheme 31. Possible one pot syntheses of three different kinds of azaheterocycle starting from the same components 65,66 in the presence of $\mathbf{2 4}$ or 43 , with microwave irradiations.

Moreover the cycloaddition of $\mathbf{2 4}$ onto nitrones $\mathbf{4 4}$ suffers unfortunately of prolongued reaction times. The introduction of microwave technology as source of heat for 1,3-dipolar cycloaddition of $\mathbf{2 4}$ and for the rearrangement of the obtained cycloadducts $\mathbf{4 7}$, could probably reduce the time required for these reactions, making the processes faster usable.

\subsection{Synthesis of Isoxazolidine or Piperidone Derivatives}

In the case of nitrone $\mathbf{4 4} \mathrm{g}$ it was possible, by selecting the conditions, to obtain indipendentely the cycloadduct $47 \mathrm{~g}$ or the piperidone $49 \mathrm{~g}$. The target molecules were prepared, starting from 
the nitrone (Scheme 32 and 33 for $\mathbf{4 7 g}$ and $49 \mathrm{~g}$, respectively) or after condensation of hydroxylamine 65d and aldehyde 66- $\mathrm{H}$ and in situ addition to the dipolarophile (Scheme 34 and 35 for $\mathbf{4 7} \mathrm{g}$ and $\mathbf{4 9 g}$, respectively).

$N$-( $p$-Methoxybenzyl)methyleneamine- $N$-oxide (44g) reacted with bicyclopropylidene (24) in 30 minutes at $80^{\circ} \mathrm{C}$, using tetrachloroethane as a solvent. After column cromatography the desidered 8-( $p$-methoxybenzyl)-7-oxa-8-aza-dispiro[2.0.2.3]nonane (47g) was obtained in $49 \%$ yield (Scheme 32 ).

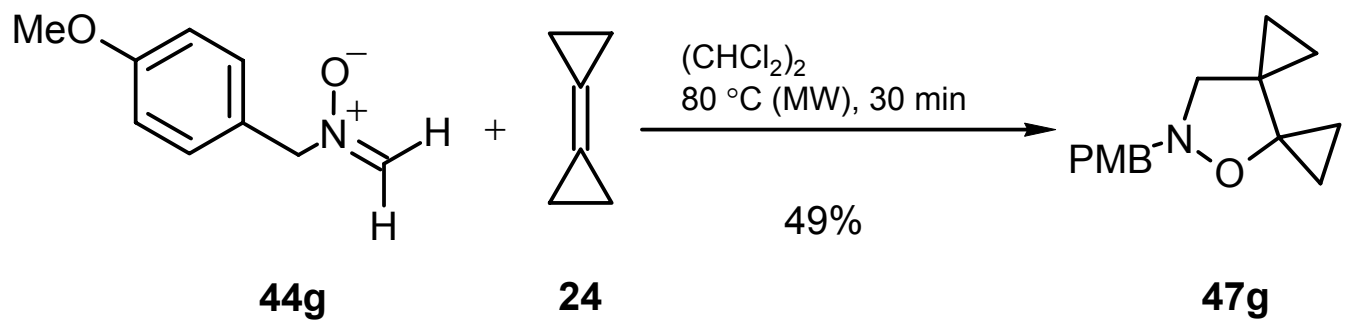

Scheme 32. 1,3-Dipolar cycloaddition of $\mathbf{4 4 g}$ and $\mathbf{2 4}$ under microwave heating.

The same components $\mathbf{4 4} \mathrm{g}$ and $\mathbf{2 4}$, if heated at a higher temperature, led selectively to the thermal rearrangement product 5-( $p$-methoxybenzyl)-5-azaspiro[2.5]octan-8-one $(49 \mathrm{~g})$ in 15 minutes. The yield after purification by column cromatography was $29 \%$ (Scheme 33 ).

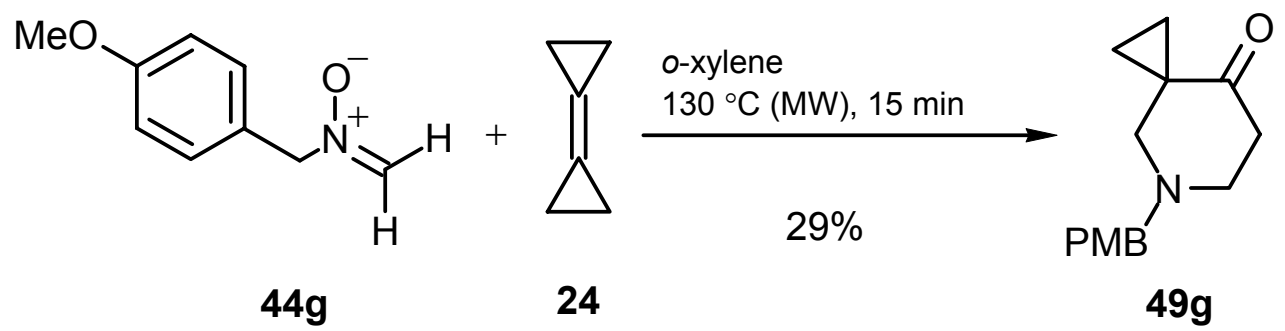

Scheme 33. Thermal rearrangement to $49 \mathrm{~g}$ under microwave heating.

The cycloadduct $47 \mathrm{~g}$ and the rearranged product $49 \mathrm{~g}$ were obtained as well by the in situ generation of the unstable nitrone $\mathbf{4 4} \mathrm{g}$ but no significant improvement in yield was observed. 
For both processes, the free hydroxylamine 65d was stirred with formaldehyde 66- $\mathrm{H}$ and dipolarophile $\mathbf{2 4}$ in the absence of acids. The presence of free protons would in fact favour the rearrangement of the cycloadduct to $\beta$-lactams (Chapter 2). When the reaction components were heated for 15 minutes in xylene at $100{ }^{\circ} \mathrm{C}$, the cycloadduct $47 \mathrm{~g}$ was obtained in $49 \%$ yield after column cromatography purification (Scheme 34).

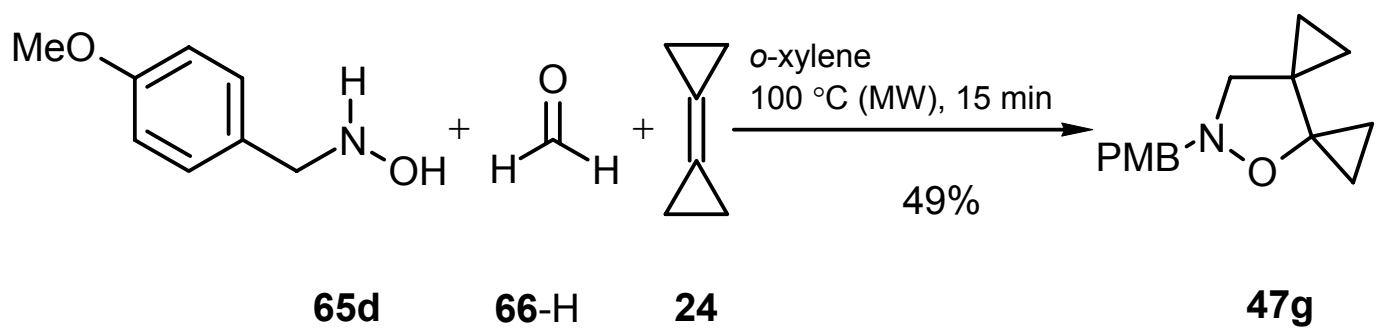

Scheme 34. Generation of the nitrone and in situ cycloaddition to 24 .

The same reagents, heated at a higher temperature, gave the piperidone $49 \mathrm{~g}$ in $37 \%$ yield after purification (Scheme 35).

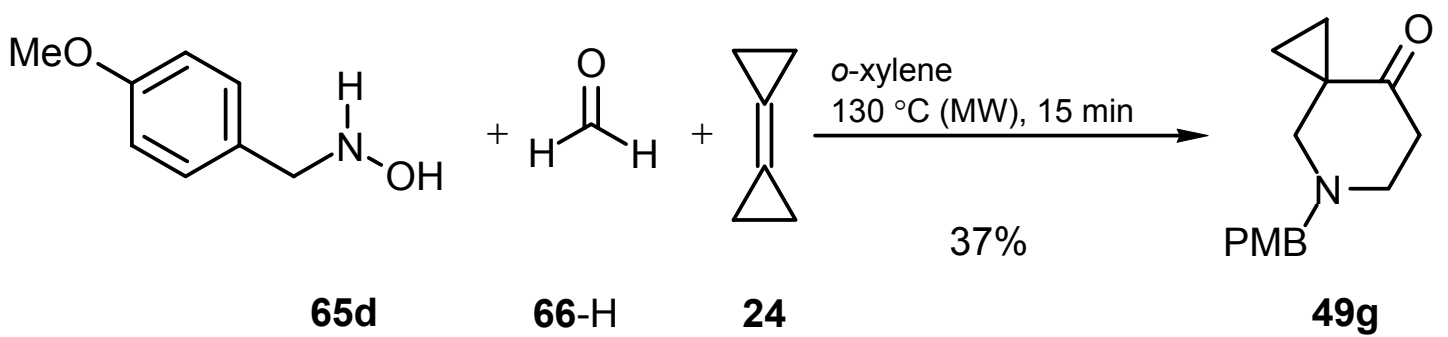

Scheme 35. Generation of the nitrone and in situ thermal rearrangement to $49 \mathrm{~g}$.

The free $N$-benzyl hydroxylamine $(\mathbf{6 5 c})$ as well, reacted with formaldehyde $66-\mathrm{H}$ and bicyclopropylidene (24) to give $\mathbf{4 7 j}$ in $54 \%$ yield and $\mathbf{4 9 j}$ in $7 \%$ yield (Scheme 36 ).

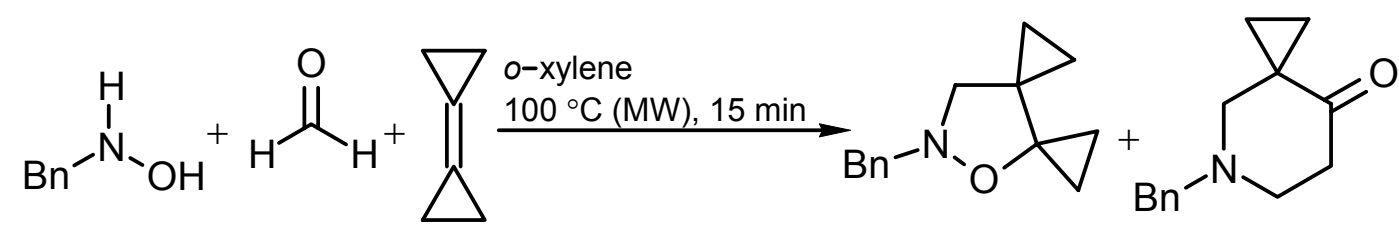
$65 c$
$66-\mathrm{H}$
24
47j, $54 \%$
49j, $7 \%$

Scheme 36. Generation of the nitrone and in situ cycloaddition to 24 and partial rearrangement to tetrahydropyridone $\mathbf{4 9 j}$. 
Compounds $\mathbf{4 7} \mathbf{g}$ and $\mathbf{4 7} \mathbf{j}$ needed (like $\mathbf{8 7}$, described in the last chapter) a high temperature NMR measurement $\left(100^{\circ} \mathrm{C}\right.$ in $\left.\mathrm{C}_{2} \mathrm{D}_{2} \mathrm{Cl}_{4}\right)$ to obtain well resolved signals. The molecules dynamic, in relation with the instrument time-scale, when the $C(\alpha)$ respect to the nitrogen atom on the ring (C-9) is unsubstituted, is the reason of very broad peaks in the room temperature measurements.

Ethyl glyoxylate 73 -Et and the hydroxylamine $\mathbf{6 5 e} \cdot \mathbf{H C l}$ reacted under the reaction-conditions normally used for the synthesis of $\beta$-lactams (G P 6, Exp. Part) to give ethyl 8-benzhydryl-7oxa-8-azadispiro[2.0.2.3]nonane-9-carboxylate (47e-Et): the good couple of ethanol with microwave irradiation, ${ }^{[68]}$ results in a very fast synthesis (25 minutes) (Scheme 37 ).

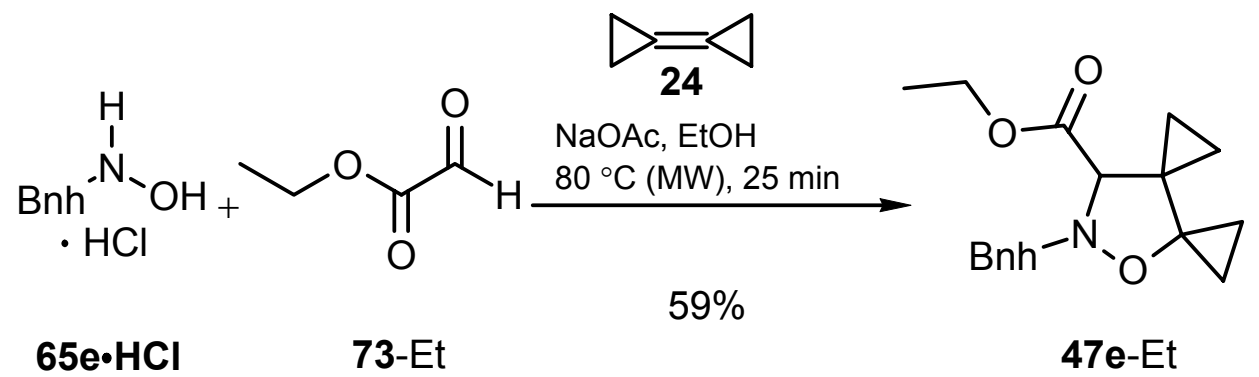

Scheme 37. Synthesis of isoxazolidine 47e-Et.

The use of microwave irradiation resulted in very short reaction times for cycladditions and rearrangements. Like for the one-pot three component synthesis of $\beta$-lactams, it's here impossible to make comparisons with the traditional heating, because these are the first experiments on these substrates. As for the cycloaddition of nitrones $\mathbf{4 4}$ to $\mathbf{2 4}$ under traditional heating, it is very important to select carefully temperature and time, to avoid the obtainment of mixtures (Scheme 36). In the case of microwave experiments, the higher reaction velocity renders the choice of those parameters in some case more difficult than with normal energy sources. The good results obtained expecially with formaldehyde allow to hope for further applications of the microwave heating in this field, for the obtainment in one step of different azaheterocycles, by selecting the reaction conditions, using the same starting materials. 


\section{4. $\quad \beta$-Lactam Ring-Opening with $N$ - and $O$-Nucleophiles and Formation of Dipeptides Containing 1-(Aminomethyl)cyclopropanecarboxylic Acid Residues}

\subsection{Considerations}

Many $\beta$-amino acids are building blocks for peptides and antibiotics ${ }^{[69 a]}$ which were isolated from plants and, more often, from marine microorganisms. ${ }^{[69 b]}$ Recently, the biosynthesis of the phenylisoserine side chain of Taxol (38) was studied (Figure 8, Introduction). ${ }^{[70,71]}$

Early studies by Abderholden, for example, suggested that peptide bonds involving $\beta$-amino acids are resistent to enzymatic hydrolysis. ${ }^{[72]}$ Certain $\beta$-amino acids have been incorporated into naturally occurring peptides with important pharmacological properties to improve resistance against degradation. ${ }^{[73]}$

$\beta$-amino acids and $\beta$-oligopeptides proved resistence to diverse and highly potent peptidases (pronase, proteinase $\mathrm{K}, 20 \mathrm{~S}$ proteosoma) and to microorganisms (Pseudomonas aeruginosa and Pseudomonas putida). ${ }^{[74]}$

In the past years, de Meijere et al. have shown how $\beta$-amino acids containing a cyclopropane ring in the $\beta$ position $\left(\beta^{3,3}\right.$ - or $C(\beta)$-modified- $\beta$-alanines 32- $\beta$ ) can be used to obtain 4 -spirocyclopropanated-2-azetidinones 33- $\beta$ (Figure 6, Introduction). ${ }^{[22,23]}$ With an inverse process the spirocyclopropyl- $\beta$-lactams 53, obtained with the rearrangement of isoxazolidines 47 , can be opened to obtain $\beta$-amino acids 96 (Scheme 38).

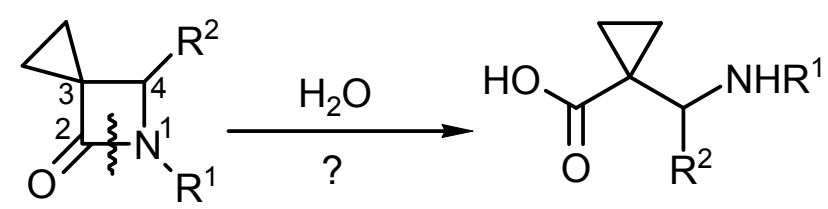

53

96

Scheme 38. Spirocyclopropyl- $\beta^{2,2}$-Modified- $\beta$-alanine 96 synthesis, via ring opening of $\beta$ lactam 53.

The ring-opening of 2-azetidinones with $N$-nucleophiles has been already published from the group of Bhupathy, ${ }^{[75]}$ and Palomo et al. performed a coupling of $\alpha$-amino acid esters 98 with activated $N$-Boc protected $\beta$-lactams 97a-c, containing a spirocycloalkyl group in position 4 (Scheme 39). ${ }^{[76]}$ 


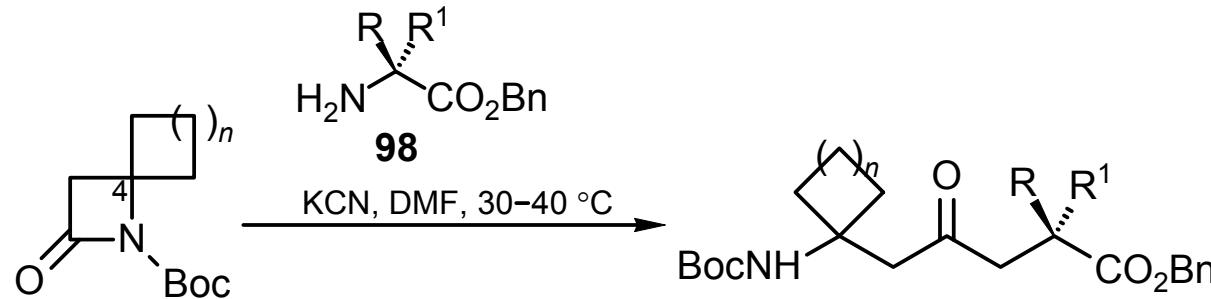
$97 \mathrm{a} n=1$
99a $n=1$
$97 \mathrm{~b} n=2$
$99 \mathrm{~b} n=2$
$97 \mathrm{c} n=3$
99c $n=3$

Scheme 39. Ring opening of Boc-protected $\beta$-lactams 97a-c with the amino ester 98.

The coupling of suitable protected glycine and $\beta$-lactams 53 could directly give simple dipeptides, ${ }^{[65]}$ in which the $\beta$-alanine part would act as a conformational lock.

\section{2. $\quad$ Attempted Ring-Opening of $\beta$-Lactams with $N$-Nucleophiles}

Some experiments were conducted to perform the coupling of $\alpha$-amino acids and 3 -spirocyclopropanated- $\beta$-lactams 53. 5-Methyl-6-phenyl-5-azaspiro[2.3] hexane-4-one (53f) ${ }^{[65]}$ did not react with the ethyl ester of glycyne 100. The amino ester $\mathbf{1 0 0}$ was used as hydrochloride. A first experiment was conducted using triethylamine in refluxing dichloromethane, ${ }^{[77]}$ but just starting material was recovered after 4 days (method A, Scheme 40).

After that, it was tried the generation in situ of an amide base, adding under argon atmosphere the amino ester hydrochloride to a flask containing KH in anhydrous THF. The mixture was heated at $60{ }^{\circ} \mathrm{C}$, but no reaction was observed (method B, Scheme 40). ${ }^{[78]}$

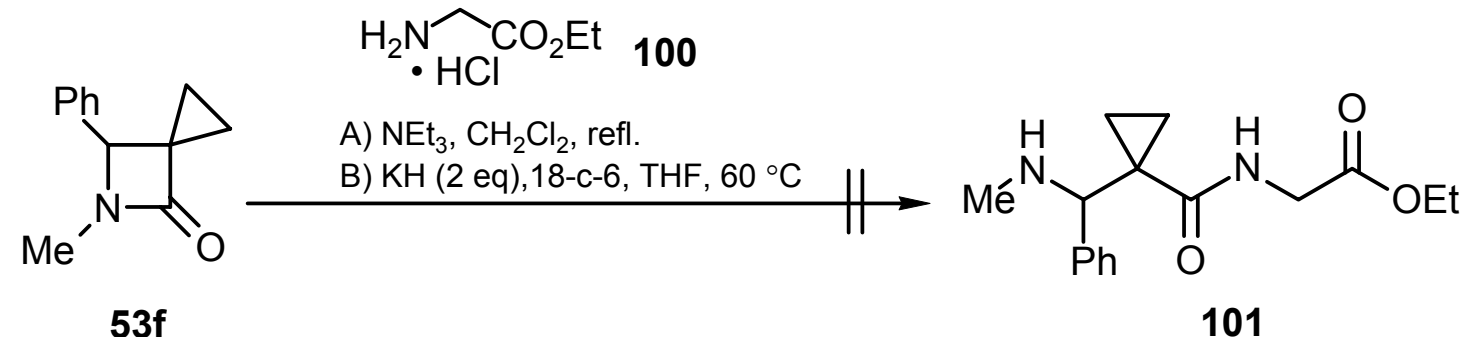

Scheme 40. Failed attempts of N1-C2 ring opening of compound 53f. 
It was also tried the tert-Butylester of glycine $\mathbf{1 0 2}$ as $N$-nucleophile on 5-benzyl-6-phenyl-5azaspiro[2.3] hexane-4-one (53a), but only starting material was recovered (Scheme 41).

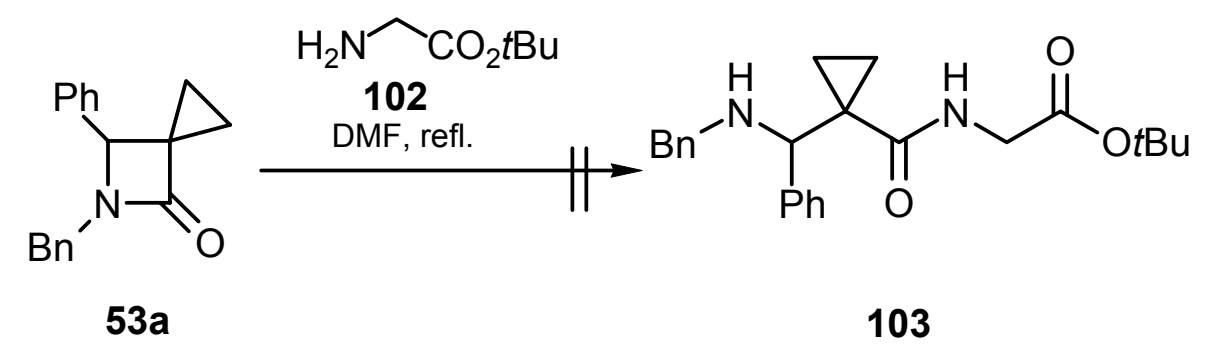

Scheme 41. Failed attempt of N1-C2 ring opening of compound 53a.

Without any further activation of the substrate, like it could be conferred from a different substitution at the nitrogen atom, the ring opening at the N1-C2 bond does not take place.

These experimental results suggest that the presence of the spirocyclopropyl ring in position 3 on the $\beta$-lactam is not able to introduce on the heterocycle enough strain to render it prone to the ring opening, i.e. to the coupling with an amino esters, via amide-bond breaking.

\subsection{Changing the Character of the $N$-Protecting Group}

Since in the literature no $\mathrm{N}$-nucleophilic ring-openings are known for $\mathrm{N}$-alkylprotected-2azetidinones, like 53a and 53f, one possible way to make this transformation could be the activation of the $\beta$-lactams $\mathbf{5 3}$ toward this reaction introducing an acyl group at the nitrogen atom. In order to create the suitable substrate, (see Scheme 39) two different strategies have been applied:

1. Deprotection-reprotection sequence: the N1 on the ring must be deprotected from the alkyl group and reprotected with a more electron-withdrawing group.

2. Oxidation of the benzylic $\mathrm{CH}_{2}$ to $\mathrm{C}=\mathrm{O}$ : the alkyl protecting group had to be transformed, so that its electronical properties are inverted.

Unfortunately, attempted debenzylation of $N$-benzyl protected compounds 53a-b and $\mathbf{5 3} \mathbf{c}-\mathrm{H}$, by hydrogenation under palladium catalysis led to hydrogenolytic opening of the $\mathrm{N}-\mathrm{C}\left(\mathrm{R}^{2}\right)$ bond on the lactam ring when $\mathrm{R}^{2}=\mathrm{Ph}(\mathbf{5 3 a})$ and no reaction occurred for $\mathrm{R}^{2} \neq \mathrm{Ph}(\mathbf{5 3 b}, \mathbf{j})$ (Scheme 42). 


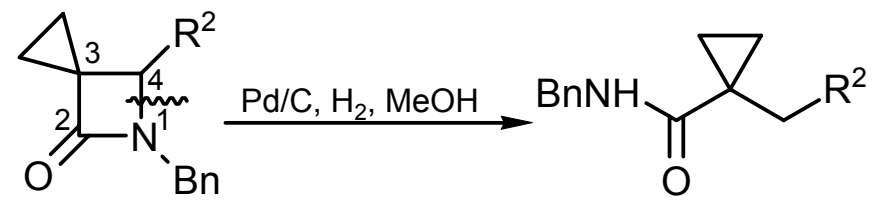

$\begin{array}{llll}\text { 53a } & \mathrm{R}^{2}=\mathrm{Ph} & 104 & \mathrm{R}^{2}=\mathrm{Ph} \\ \text { 53b } & \mathrm{R}^{2}=\mathrm{CO}_{2} \mathrm{Me} & \mathbf{5 3 b} & \mathrm{R}^{2}=\mathrm{CO}_{2} \mathrm{Me} \\ \text { 53j } & \mathrm{R}^{2}=\mathrm{H} & \mathbf{5 3 j} & \mathrm{R}^{2}=\mathrm{H}\end{array}$

Scheme 42. Attempted debenzylation with palladium on carbon.

The former result was not surprising, because Ojima and co-workers found that cleavage of the $\mathrm{C} 4-\mathrm{N} 1$ bond in 2-azetidinones 105 proceeds by palladium-catalysed hydrogenolysis, when an aryl substituent is attached to the $\mathrm{C} 4$ position (Scheme 43$){ }^{[79]}$

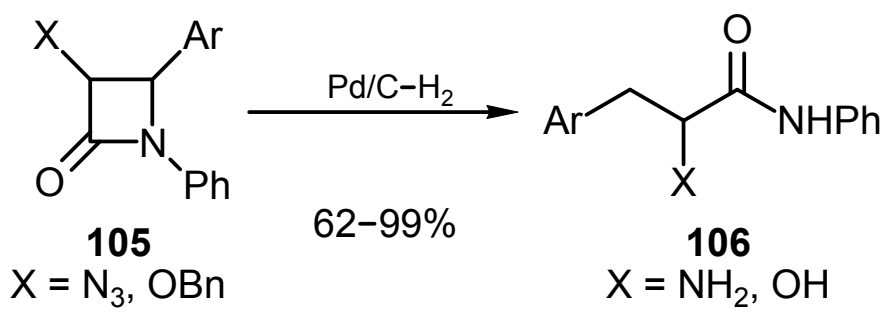

Scheme 43. N1-C4 ring-opening in the presence of aryl-substituents on the C4.

Attempted debenzylations of 53a by buffered sodium persulfate ${ }^{[80 a]}$ or of 53c under Birch conditions (sodium in ammonia) ${ }^{[80 b]}$ only led to no reaction or decomposition of the starting material, respectively. A procedure ${ }^{[80 \mathrm{c}]}$ that uses $t \mathrm{BuLi}$ and bubbled dry-oxygen, destroyed 5(benzyl)-5-azaspiro[2.3]hexan-4-one (53j) (Scheme 44).

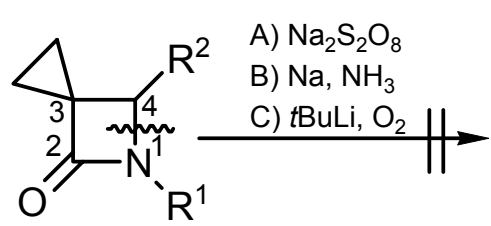

53

\begin{tabular}{cccc}
\hline 53 & $\mathrm{R}^{2}$ & Method & Result \\
\hline a & $\mathrm{Ph}$ & $\mathrm{A}$ & No reac. \\
$\mathbf{c}$ & $\mathrm{CN}$ & $\mathrm{B}$ & decompos. \\
$\mathbf{j}$ & $\mathrm{H}$ & $\mathrm{C}$ & decompos. \\
\hline
\end{tabular}

Scheme 44. Attempted debenzylation by other methods than hydrogenation.

However, the alternative approach by oxidation of the benzylic methylene to carbonyl group turned out to be more successful (Scheme 45). This type of oxidation was achieved for 
compounds 53a,b with potassium permanganate in acetic acid/acetone mixture $(\operatorname{method} \mathrm{A})^{[81 \mathrm{a}]}$ or chromium trioxide in acetic acid $(\operatorname{method} \mathrm{B})^{[81 b]}$ which furnished the corresponding $\mathrm{N}$ benzoyl- $\beta$-lactams 107a,b in 28 and 44\% yield (Scheme 45). The methylene group in the more labile $p$-methoxybenzyl group of the $\beta$-lactam 53d can be oxidized using cerium ammonium nitrate $(\mathrm{CAN})$ in aqueous acetonitrile (method $\mathrm{C}) .{ }^{[81 \mathrm{c}]}$ However, this oxidation was accompanied by oxidative $N$-deprotection of 53d to give $N$-( $p$-methoxybenzoyl)- $\beta$-lactam 107d and $N$-deprotected $\beta$-lactam 108 in almost equal yield (39 and 38\%, respectively) (Scheme 45).

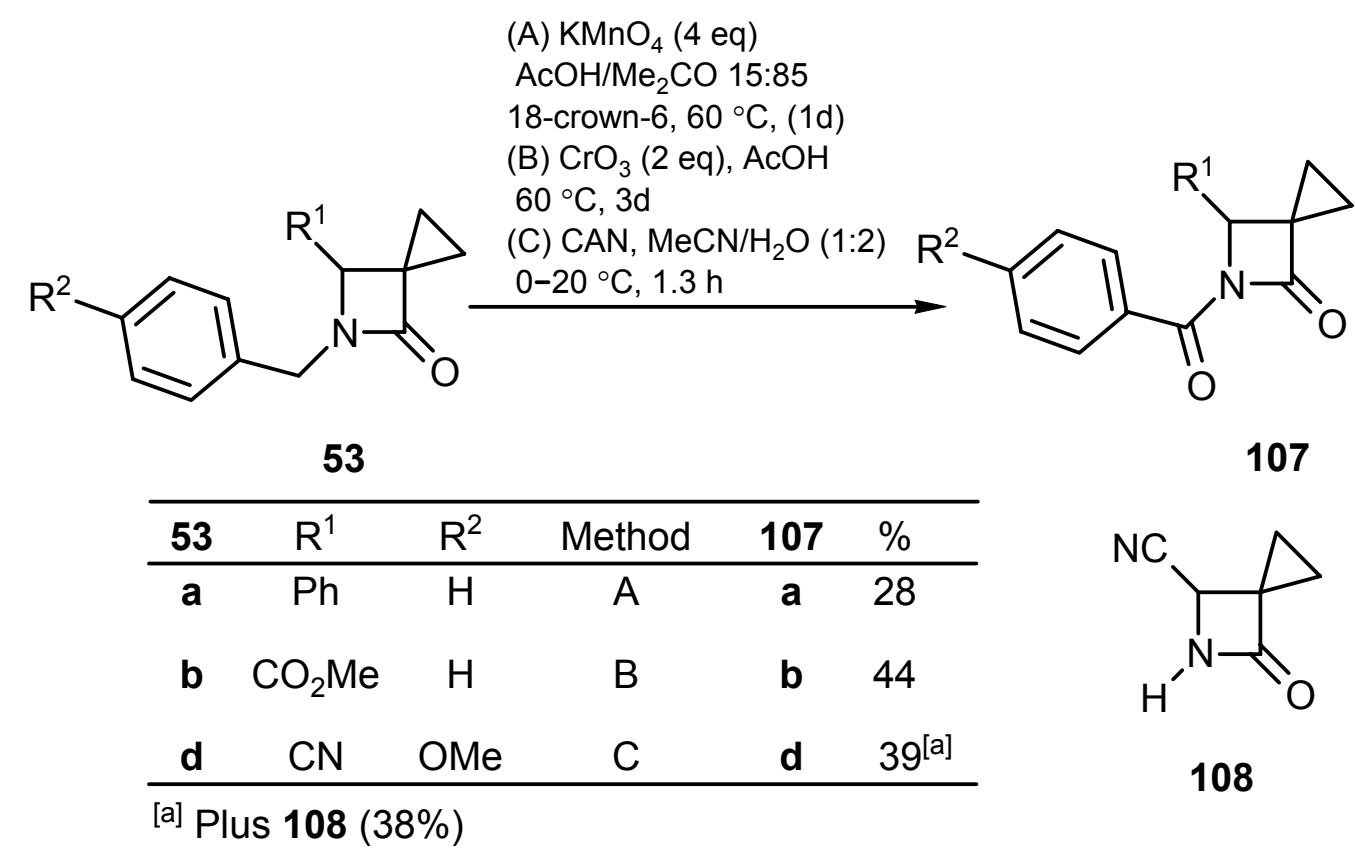

Scheme 45. Oxidation of the benzylic methylene group in $\beta$-lactams 53a,b,d

The structure of the $N$-benzoyl- $\beta$-lactam $\mathbf{1 0 7 b}$ was rigorously proved by an X-Ray crystal structure analysis (Figure 19). 


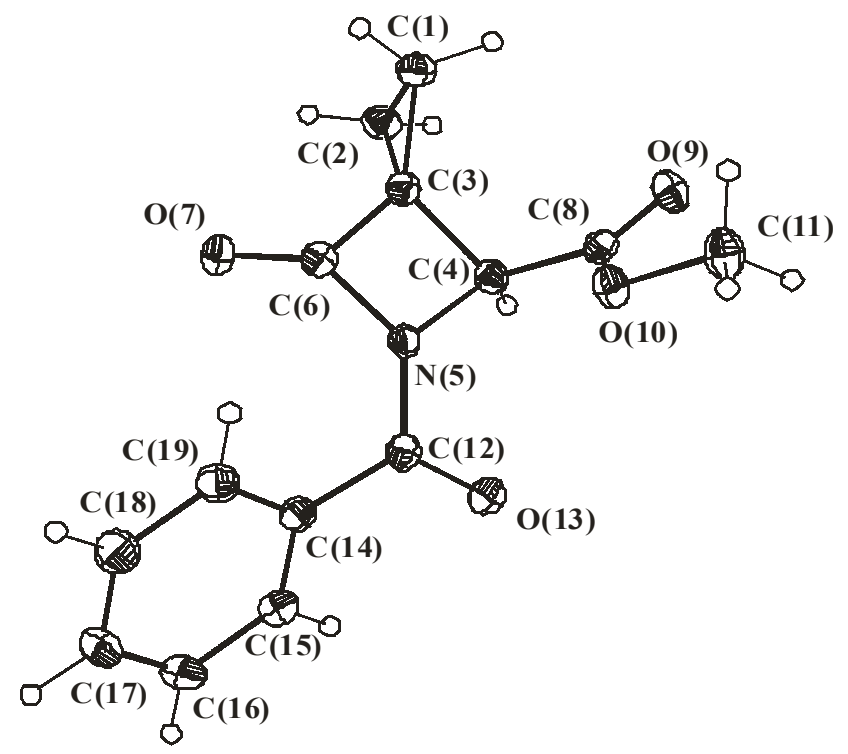

Figure 19. X-Ray crystal structure analysis Methyl 5-Benzoyl-6-oxo-5-azaspiro[2.3] hexane-4-carboxylate (107b).

\begin{tabular}{cccc}
\hline Bond & lenght [pm] & angles & amplitude [ $\left.{ }^{\circ}\right]$ \\
\hline $\mathrm{C}(3)-\mathrm{C}(4)$ & $153.7(2)$ & $\mathrm{C}(6)-\mathrm{C}(3)-\mathrm{C}(4)$ & $88.6(8)$ \\
$\mathrm{C}(4)-\mathrm{N}(5)$ & $148.2(2)$ & $\mathrm{N}(5)-\mathrm{C}(4)-\mathrm{C}(3)$ & $87.2(8)$ \\
$\mathrm{N}(5)-\mathrm{C}(6)$ & $142.9(2)$ & $\mathrm{C}(6)-\mathrm{N}(5)-\mathrm{C}(4)$ & $93.1(8)$ \\
$\mathrm{C}(3)-\mathrm{C}(6)$ & $148.9(2)$ & $\mathrm{N}(5)-\mathrm{C}(6)-\mathrm{C}(3)$ & $91.0(8)$ \\
$\mathrm{C}(6)-\mathrm{O}(7)$ & $120.0(1)$ & & \\
$\mathrm{N}(5)-\mathrm{C}(12)$ & $139.4(2)$ & & \\
\hline
\end{tabular}

Table 8. Values from the X-Ray crystal structure analysis of $107 \mathrm{~b}$.

The structure of $\mathbf{1 0 7} \mathbf{b}$ in hand allows some considerations. A precedent X-Ray analysis of an analogue, methyl (6-oxo-5-azaspiro[2.3]hex-4-yl) acetate, ${ }^{[17]}$ had already shown how the introduction of the small spiro alkyl ring doesn't increase the ring strain so much that it can be recognised in bond lenghts or angles. The values found in that case were the typicals for monocyclic $\beta$-lactams. ${ }^{[82]}$ In fact, because of the supposed newly introduced strain (the spirofused ring), it could have been expected an increase in $\mathrm{N}(5)-\mathrm{C}(6)$ bond lenght and a decrease in $\mathrm{C}(6)-\mathrm{O}(7)$ lenght, but this was not observed.

In the case of $\mathbf{1 0 7} \mathbf{b}$, the $\mathrm{N}(5)-\mathrm{C}(6)$ bond is $6.7 \mathrm{pm}$ longer than for the just cited analogue and this has to be ascribed to the presence of the additional $\mathrm{C}=\mathrm{O}$ : the $\mathrm{C}(12)-\mathrm{N}(5)$ bond lenght is infact $139.4 \mathrm{pm}$ (Table 8) and, like expected, the $\mathrm{N}$-atom lone pair forms the resonance structure with the exocyclic carbonyl instead than with the endocyclic one. 
Treatment of 77d-Me with ceric ammonium nitrate (CAN) in aqueous acetonitrile (1:3) at room temperature did indeed furnish 109 in 90\% yield (Scheme 46). In this case the deprotection occurred with no trace of cooxidation product, like for 53d (Scheme 45).

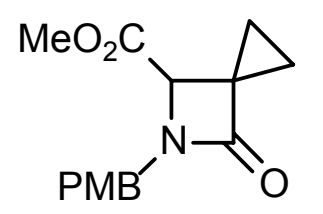

77d-Me

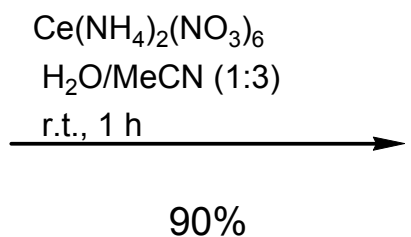

$90 \%$<smiles>COC(=O)C1NC(=O)C12CC2</smiles>

109

Scheme 46. Deprotection from the paramethoxybenzyl group in oxidative conditions.

The accessibility of deprotected derivatives like 108 and 109 allowed the synthesis of the tertbutoxycarbonyl protected derivatives 110 and 111, that were obtained in 78 and $82 \%$ yield, respectively, applying an estabilished procedure (Scheme 47). ${ }^{[83]}$

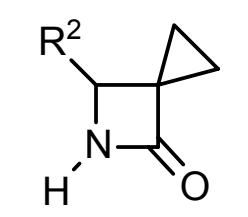

$108 \mathrm{R}^{2}=\mathrm{CN}$

$109 \mathrm{R}^{2}=\mathrm{CO}_{2} \mathrm{Me}$
$\mathrm{Boc}_{2} \mathrm{O}, \mathrm{DMAP}, \mathrm{MeCN}$

$0{ }^{\circ} \mathrm{C} \rightarrow$ r.t.,

(A) $1 \mathrm{~h},(\mathrm{~B}) 3 \mathrm{~h}$

$82 \%$<smiles></smiles>

$110 \mathrm{R}^{2}=\mathrm{CN}$

$111 R^{2}=\mathrm{CO}_{2} \mathrm{Me}$

Scheme 47. Protection of $\mathbf{1 0 8}$ and $\mathbf{1 0 9}$ with the "activating"-group Boc.

This $N$-protection offered $\beta$-lactams that, like the $\mathbf{1 0 7}$ derivatives, present an exocyclic carbonyl group bounded with the nitrogen atom.

The consequent minor double bond carachter for N1-C2 (N(5)-C(6)) means a reduced importance of the resonance structure 113 (Figure 20). This should induce a major reactivity, toward the ring opening with amino acid esters, for this kind of $\beta$-lactams in comparison with the alkyl substituted ones (53a and 53f). 


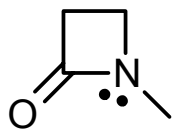

112

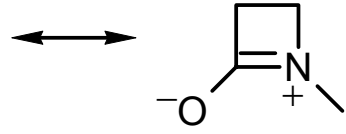

113

Figure 20. Amide-bond resonance in the $\beta$-lactam ring 112.

\subsection{Dipeptides Containing 1-(Aminomethyl)cyclopropanecarboxylic Acid Residues}

The $\beta$-lactams $\mathbf{1 0 7 b}$ and $\mathbf{1 1 0}$ were treated in the presence of $\mathbf{1 0 2}$. The electronwithdrawing groups benzoyl and tertbutoxycarbonyl on the nitrogen atom should make the internal-ring amide bond easier to break.

The $\beta$-lactams 107a, 107b and 110 did not react with tert-butyl glycinate (102) in DMF at ambient temperature. Upon heating of $\mathbf{1 0 7 b}$ with 102 in DMF under reflux $\left(152{ }^{\circ} \mathrm{C}\right)$ the ester group was transformed into a tert-butoxycarbonylmethylenamido group to give the new lactam 114 (Scheme 48) without ring opening even after prolonged heating with an excess of 102.<smiles>COC(=O)C1N(C(=O)c2ccccc2)C(=O)C12CC2</smiles>

$107 b$

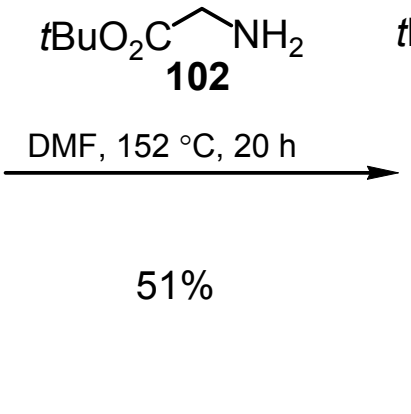<smiles>CCC(C)OC(=O)CNC(=O)C1N(C(=O)c2ccccc2)C(=O)C12CC2</smiles>

114

Scheme 48. Reaction of $N$-acylated $\beta$-lactams $\mathbf{1 0 7 b}$ with tert-butyl glycinate (102)

However, the $\beta$-lactams 107a and 110 under these conditions reacted with 102 in the desired mode to give the corresponding $\beta$-dipeptides 116 and 117 in 61 and 84\% yield, respectively (Scheme 49 and Table 9), as pure colorless solids after column chromatography (116) or without any additional purification (117). 


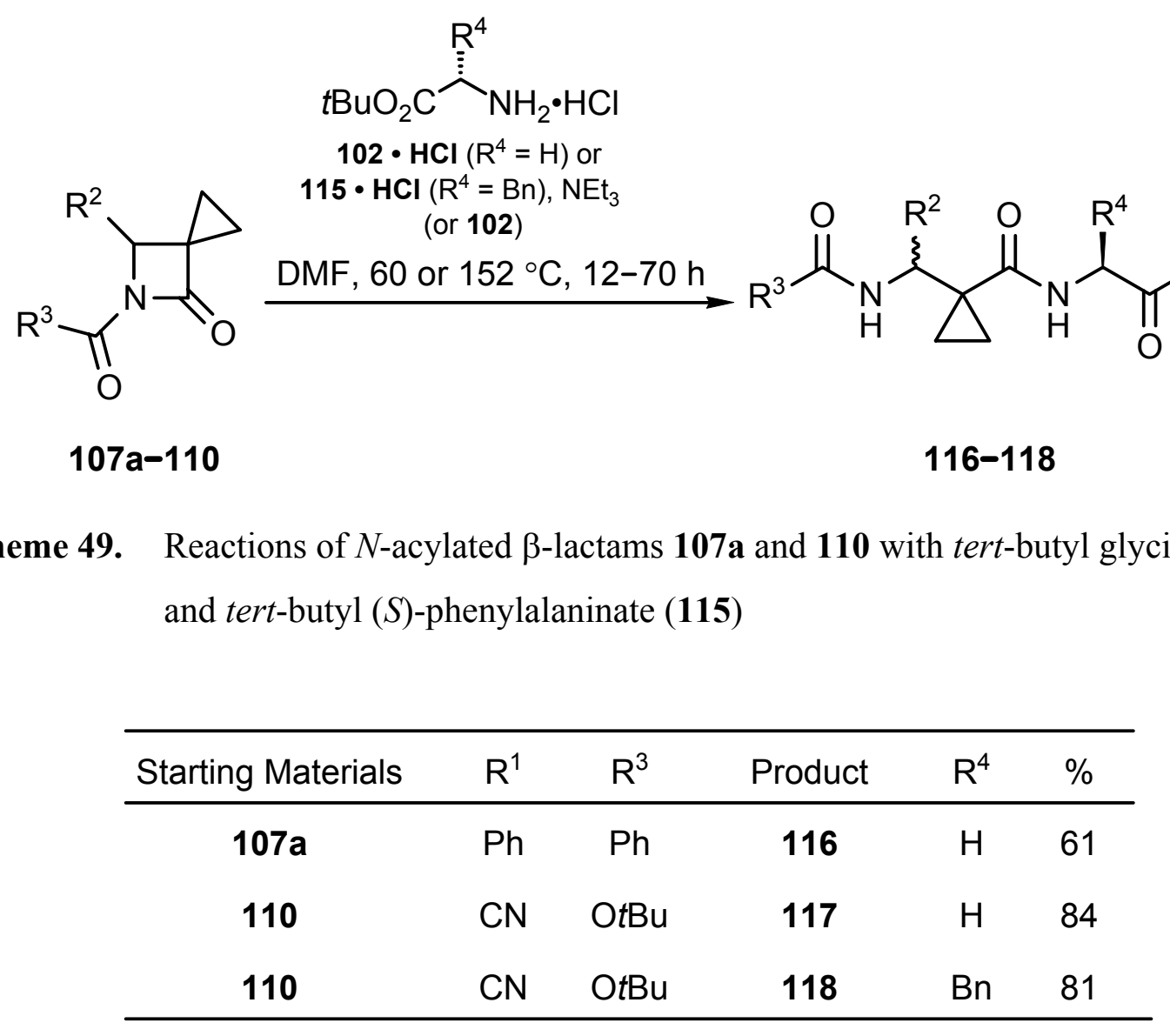

Table 9. Results for the ring-opening with amino esters 102 and 115.

Under the same conditions, a $1.1: 1$ mixture of the diastereomeric dipeptides $(2 S, 2 ' S)$-118 and $\left(2 S, 2^{\prime} R\right)$-118 was obtained from the $\beta$-lactam 110 and tert-butyl $(S)$-phenylalaninate (115). These diastereomeric dipeptides $\left(2 S, 2^{\prime} S\right)-\mathbf{1 1 8},\left(2 S, 2^{\prime} R\right)-\mathbf{1 1 8}$ could easily be separated by column chromatography (see Experimental Section), and the structure of the latter was established by an X-Ray crystal structure analysis (Figure 21). Absolute configuration of the dipeptide $\left(2 S, 2^{\prime} R\right)-\mathbf{1 1 8}$ was assigned on the basis of the known $(S)$-configuration of the tertbutyl $(S)$-phenylalaninate (115), used in the synthesis of 118. 


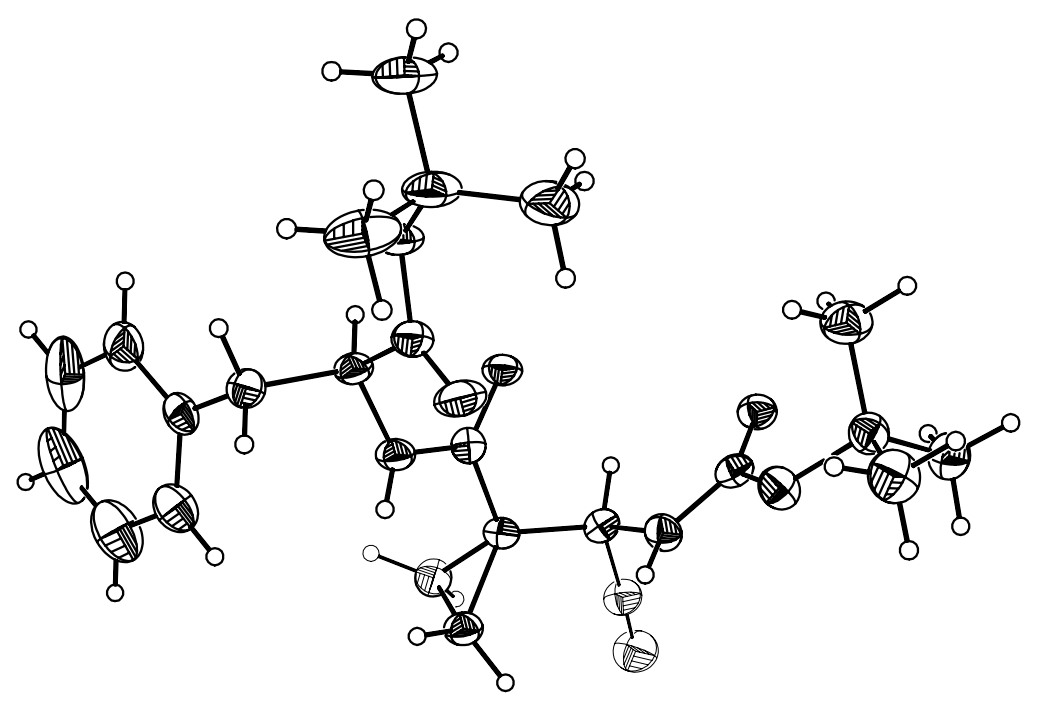

Figure 21. Molecular structure of tert-butyl $\left(2 S, 2^{\prime} R\right)-2-\{[1$-(tert-butoxycarbonylaminocyanomethyl)cyclopropylcarbonyl]amino $\}$-3-phenylpropionate $\left[\left(2 S, 2^{\prime} R\right)-\mathbf{1 1 8}\right]$ in the crystal.

\subsection{Ring Opening of $\beta$-Lactams with $O$-Nucleophiles}

Norstatine (120) $\left(\mathrm{R}^{1}=i \mathrm{Bu}\right)$ and analogues (with different $\mathrm{R}^{1}$ substituents) have been used extensively as crucial amino acid residues in peptide-based inhibitors of such enzymes as renin and HIV-I protease. A method, developed from Ojima, can lead with high enantiomeric purity to those products via the key intermediate $\beta$-lactam 119, which is opened at the N1-C2 bond with water as $O$-Nucleophile in stongly acidic conditions (Scheme 50). ${ }^{[83]}$

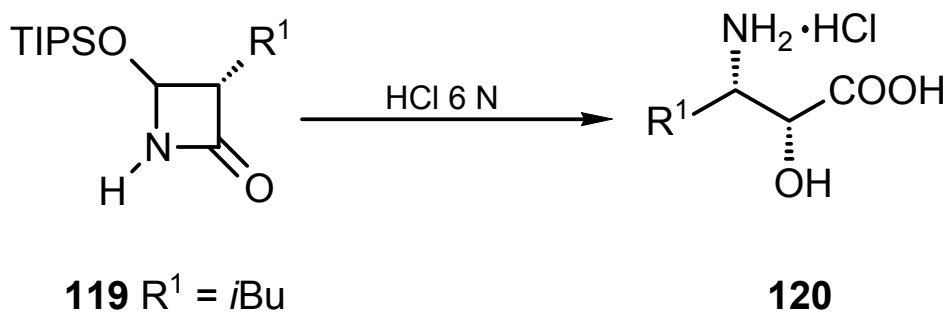

Scheme 50. Synthesis of Norstatine $120\left(\mathrm{R}^{1}=i \mathrm{Bu}\right)$.

The $\beta$-amino acidic chain, essential for Taxol (38) biological activity (Figure 8 , Introduction), is normally synthetically coupled with the precursor 10 -deacetylbaccatin 121, via $O$ Nucleophilic ring-opening of a preformed $\beta$-lactam 122, performed by the deprotonated hydroxy group at the C-13 atom on $\mathbf{1 2 1}$ (Figure 22). ${ }^{[83]}$ 


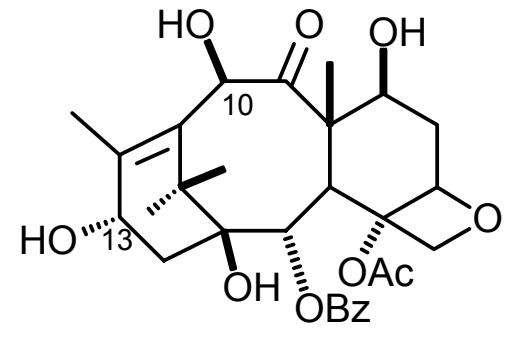

10-deacetylbaccatin III 121<smiles>[R]C(=O)N1C(=O)[C@@H](OC)[C@@H]1c1ccccc1</smiles>

122a $\mathrm{R}=\mathrm{Ph}$

$122 \mathrm{~b} R=t \mathrm{BuO}$

Figure 22. Starting materials for the semisynthesis of Taxol (38).

Methyl 1-(Benzoylamino-phenyl-methyl)cyclopropane carboxylate (123) was obtained, just treating the compound $\mathbf{1 0 7 a}$ in stongly acidic conditions with trimethylchlorosilane in methanol (Scheme 51).

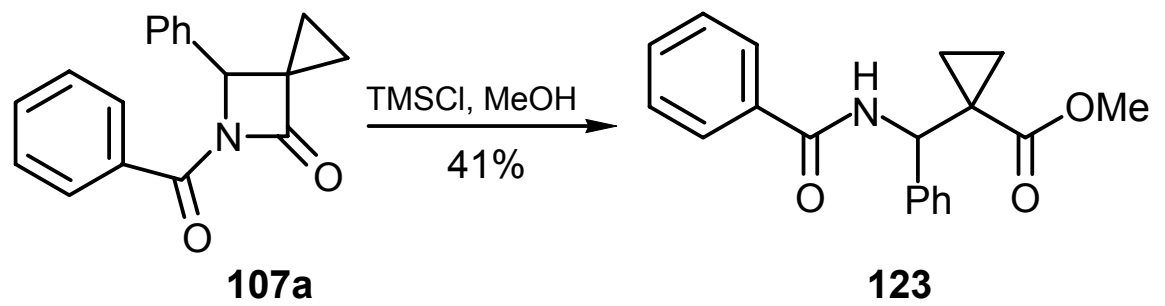

Scheme 51. Ring-opening to Methyl 1-(Benzoylamino-phenyl-methyl)cyclopropane carboxylate (123).

The purification by cromatography gave $\mathbf{1 2 3}$ as a colorless solid in $41 \%$ yield. The structure of 107a reminds to the compound 122a used from Ojima for the semisynthesis of Taxol and analogues, ${ }^{[83]}$ with the only difference on the position 3 , where it's located a cyclopropyl group instead of a protected hydroxy group ( $\mathrm{EE}=$ ethoxy-ethoxy) (Figure 22). 


\section{Attempted Synthesis of a Poly( $\beta$-peptide), Consisting of 1- (Aminomethyl)cyclopropanecarboxylic Acid}

\subsection{Considerations}

Before the detailed studies conducted by Seebach on folding of $\beta$-peptides of different kinds, the structure of monodisperse $\beta$-peptides had not accurately been estabilished. ${ }^{[84]}$ Just controversal reports on the structure of $\beta$-peptides and of $\beta$-amino acids polymers have appeared in the literature since the early $60^{\circ} \mathrm{s}$, based on IR, CD, fiber X-Ray and NMR methods. A $\beta$-sheet conformation was assigned to several polydisperse poly( $\beta$-amino acid)s, the so called nylon-3 derivatives 124, constituted of a 3-carbonbackbone polyamide (Figure 23). ${ }^{[85]}$

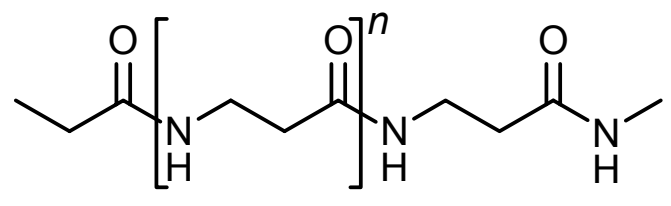

124

Figure 23. Nylon-3 structure.

However, more recently it was shown from fiber X-ray scattering that poly $(\alpha$-alkyl- $\beta-L$ aspartate)s adopt helical structures. ${ }^{[86]}$ Poly- $\beta$-aspartates 127 are biologically degradable polymers, obtainable by anionic polymerization of readily available $\beta$-lactam 125 of $L$ aspartic acid (Scheme 52). ${ }^{[86]}$

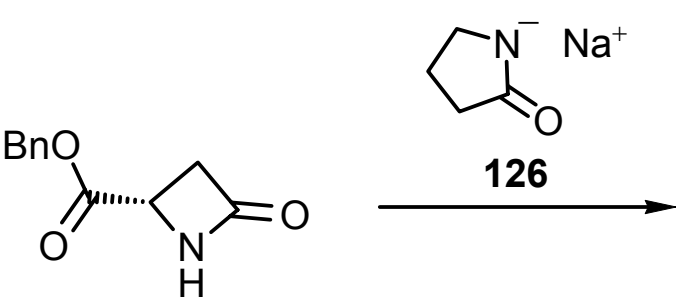

125<smiles>CCC(=O)C[C@H](NC(C)CC)C(=O)OBr</smiles>

127

Scheme 52. Anionic polymerization of $\mathbf{1 2 5}$ to give poly- $\beta$-aspartate $\mathbf{1 2 7}$. 
While the mechanism of formation and the parameters determining the stability of secondary structures of proteins (including the helix, the pleated sheet and the turn) are not yet totally understood, $\beta$-peptides adopt well-defined secondary structures that can also be predicted by calculations, when their backbones are not conformationally restricted by cyclic residues. ${ }^{[87]}$ Part of the huge work due to the group of Seebach has furnished the informations about the folding of $\beta$-peptides, derived from couplings of 1-(aminomethyl)cyclopropane carboxylic acid (41) units (Figure 24 and Figure 11, Introduction). ${ }^{[30]}$<smiles>COC(=O)C1(CNC(=O)C2(CNC(=O)C3(CNC(=O)OCc4ccccc4)CC3)CC2)CC1</smiles>

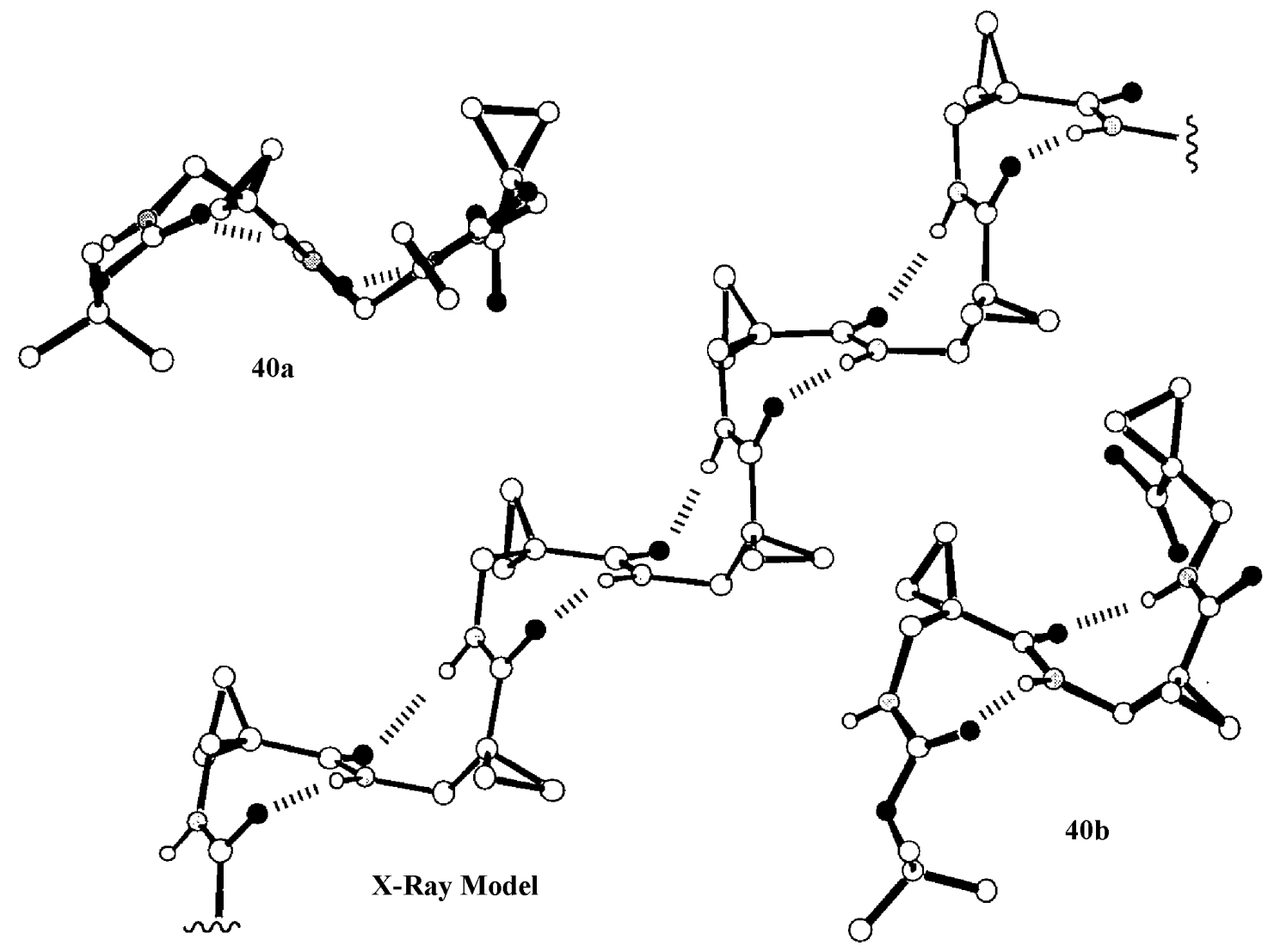

Figure 24. X-Ray structures of oligomers $\mathbf{4 0 a , b}$ and model for a polymer.

Collecting the parameters from X-Ray analyses of the oligomers 40, a polymer model has been created, on which the carbonyl groups adjacent to the cyclopropane create the ordering factor, that leads to the formation of eight-membered rings between neighbour units. 
Real poly( $\beta$-peptides) can been prepared via condensation of short peptides, ${ }^{[88-90]}$ polymerization of $\beta$-amino acid-N-carboxyanhydrides, ${ }^{[91-95]}$ copolymerization of carbon monoxide and aziridine, ${ }^{[96]}$ and polymerization of $\beta$-lactam, ${ }^{[86,87,97-99]}$ which is the best method that can furnish high molecular weight polymers. The best reported control in $\beta$-lactam polymerizations was obtained by Šebenda and Hashimoto, who prepared narrow molecular weight distribution, low-molecular weight poly( $\beta$-peptides) anionically, using $N$-acyl-lactam activators, ${ }^{[97,98]}$ and by Cheng and Deming ${ }^{[100]}$ who used metal-amido complexes to control the polymerization.

The anionic polymerization of 5-aza-spiro[2.3]hexan-4-one (128) (Figure 25), would lead to structures, whose folding should resumble the calculated model (Figure 24).

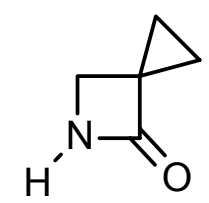

128

Figure 25. Monomer 128 for the anionic polymerization to poly- $\beta$-cyclopropanatedamide.

\subsection{Synthesis of 5-Azaspiro[2.3]hexan-4-one}

The synthesis of the monomer $\mathbf{1 2 8}$ for the anionic polymerization, was obtained via deprotection with ceric ammonium nitrate of the analogue 53g, in 33\% yield (Scheme 53). The amount of starting material necessary for this deprotection step is limited from the volume of the vessels disposable for the microwave oven $(3.5-5 \mathrm{~mL})$ and no more than a $5 \mathrm{mmol}$ scale can be used for this reaction. The low yield, obtained for the deprotection, cannot furnish amount of $\mathbf{1 2 8}$ sufficient for a polymerization on larger scale.

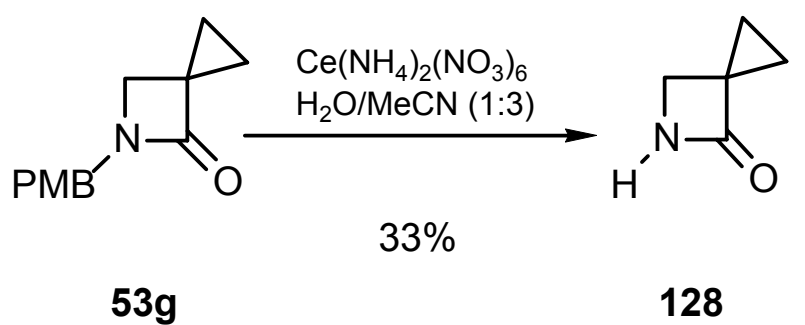

Scheme 53. Synthesis of 5-aza-spiro[2.3]hexan-4-one (128) via deprotection of 53g. 
The monomer 5-aza-spiro[2.3] hexan-4-one (128) can also be imagined as deriving from the ring-closure of the corresponding $\beta$-alanine derivative methyl 1-(aminomethyl)-cyclopropane carboxylate (130) (Scheme 54).

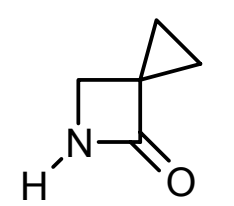

128

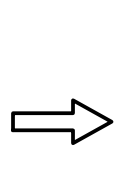

130

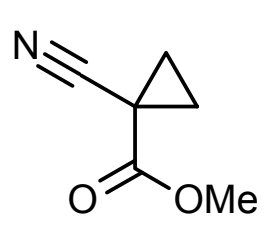

129

Scheme 54. A different synthetic strategy to 128.

$\alpha$-Cyclopropyl-modified $\beta$-alanines 32- $\alpha$ (Figure 6, Introduction) can be easily prepared. Commercially available 1-cyanocyclopropanecarboxylic acid 132, also easily prepared from dialkylation of methyl cyanoacetate with 1,2-dibromoethane in DMF with $\mathrm{K}_{2} \mathrm{CO}_{3}{ }^{[101]}$ or from trimethylsilylacetonitrile, ${ }^{[102]}$ offers a simple, but most effective entry, into a $\alpha$-cyclopropylmodified $\beta$-alanine (Scheme 55).

The cyano group can be reduced with catalytic hydrogenation in the presence Platinum oxide to lead to $\mathbf{1 3 3}$ (conditions a, Scheme 55), and subsequent protection of the amino group (conditions b, Scheme 55) gives rise to the $N$-Boc-protected amino acid 134, being suitably functionalized to be incorporated into peptides.

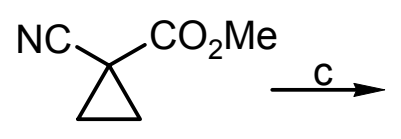

129

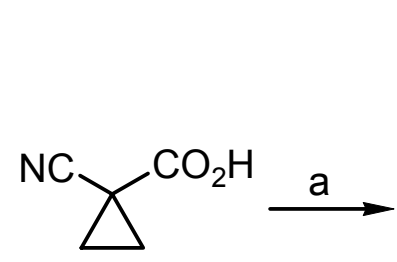

132<smiles>COC(OC)C1(CN)CC1</smiles>

130

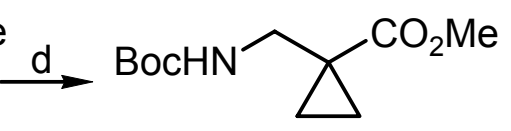

131

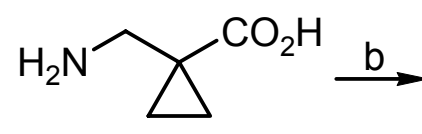

133

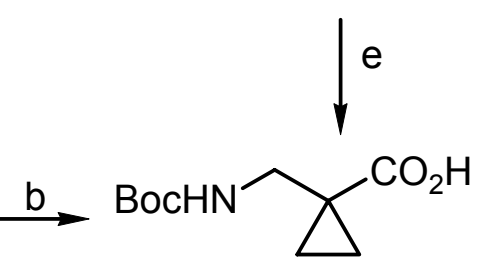

134

Scheme 55. Reagents and conditions: (a) $\mathrm{H}_{2}, \mathrm{PtO}_{2}, \mathrm{HOAc}, 86 \%$; (b) $\mathrm{Boc}_{2} \mathrm{O}, \mathrm{NaOH}$, dioxane, 93\%; (c) $\mathrm{H}_{2}$, Raney-Ni, $\mathrm{MeOH}, 1$ bar, rt, 4 h; (d) $\mathrm{Boc}_{2} \mathrm{O}, \mathrm{MeCN}$, $\mathrm{NEt}_{3}, 0{ }^{\circ} \mathrm{C}, 2 \mathrm{~h}, 80 \%$ (2 steps); (e) $\mathrm{LiOH}, \mathrm{MeOH}, \mathrm{rt}, 3 \mathrm{~d}, 48 \%$. 
Likewise, the methyl ester 129 can be converted to the aminoester $\mathbf{1 3 0}$ by catalytic hydrogenation over Raney-Nickel (conditions c, Scheme 55), freshly prepared, followed by $N$-Boc protection (conditions d, Scheme 55) to 131 and subsequent saponification to $\mathbf{1 3 4}$ (conditions e, Scheme 55). ${ }^{[30,103]}$

\subsection{Ring Closure of Methyl 1-(Aminomethyl)cyclopropane carboxylate}

Ring closures to 4-membered lactam through reaction of the amino group with the ester function on the same molecule are well known reactions. Several $C(\alpha)$-mono- and -disubstituted $\beta$-amino esters give easliy the cyclization upon treating with strong bases in ethereal solvents. Following the work from Kise and Ueda, ${ }^{[104]}$ a first attempt consisted in addition at $0{ }^{\circ} \mathrm{C}$ of a $0.3 \mathrm{M}$ solution of $\mathbf{1 3 0}$ in THF to a $0.3 \mathrm{M}$ solution of LDA in THF/hexane, freshly prepared from the amine and buthyl lithium at $-78{ }^{\circ} \mathrm{C}$. The desired azetidinone 128 was obtained in $21 \%$ yield (Scheme 56 ). The rest of $\mathbf{1 3 0}$ polymerized to an unsoluble colorless solid.

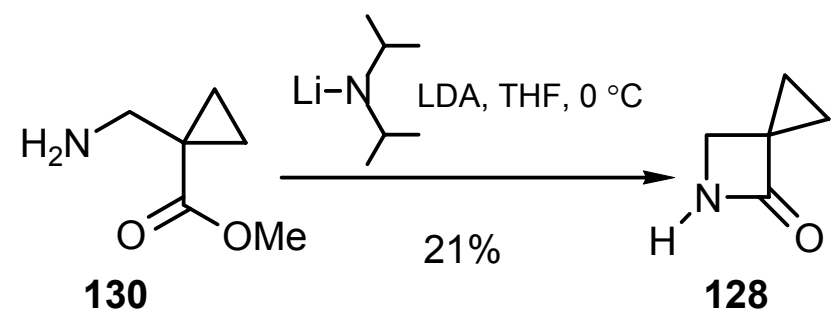

Scheme 56. Cyclization to 5-aza-spiro[2.3]hexan-4-one (128).

Since $\mathbf{1 3 0}$ seemed to be not perfectly soluble in THF, the previous reaction was tried adding a solution $0.09 \mathrm{M}$ of it in diethyl ether to a LDA solution in tetrahydrofurane. Unfortunatly also in this case polymerization was observed.

EtMgBr was used as base at room temperature or at $0{ }^{\circ} \mathrm{C}$, but no improvement respect to the first tried method was observed. ${ }^{[105]}$

The methyl 1-(aminomethyl)cyclopropane carboxylate (130) was transformed in his hydrochloric salt, because of the lower lability of the latter respect to the free amine. After ricrystallization from petrol ether, the pure salt $\mathbf{1 3 0} \cdot \mathbf{H C l}$ was obtained in $91 \%$ yield.

The free amino ester 130, prepared from the latter and directly used for the reactions, should be more free from impurities than the same compound stored for a long time after distillation. 
The procedure of Avenoza ${ }^{[106]}$ was repeated, adding very slowly (4 h) a solution of the starting material 130 in $\mathrm{CH}_{2} \mathrm{Cl}_{2}$, obtained from 130. $\mathbf{H C l}$, to the Grignard reagent solution, but only 6\% yield in 128 was obtained (Scheme 57).

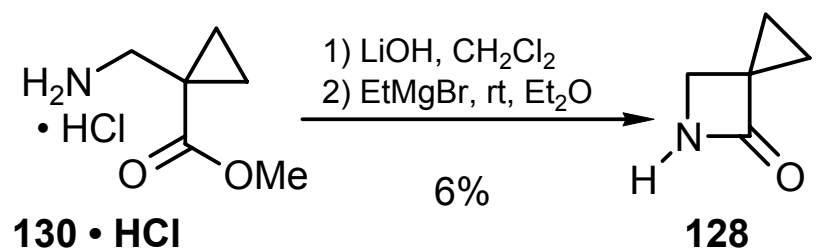

Scheme 57. Cyclization to 5-aza-spiro[2.3]hexan-4-one (128) with a different strong base.

The compound $\mathbf{1 3 0} \cdot \mathbf{H C l}$ was transformed into the trifluoroacetic acid salt of 1-(aminomethyl)-cyclopropane carboxylic acid (135), modifying known procedures, ${ }^{[103]}$ so that the yield in the single steps were improved (Scheme 58).

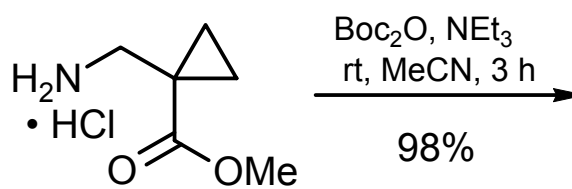

$130 \cdot \mathrm{HCl}$<smiles>COC(=O)C1(CNC(=O)OCc2ccccc2)CC1COC(=O)O</smiles>

131<smiles>CC(C)(C)OC(=O)NCC1(C(=O)O)CC1</smiles>

134

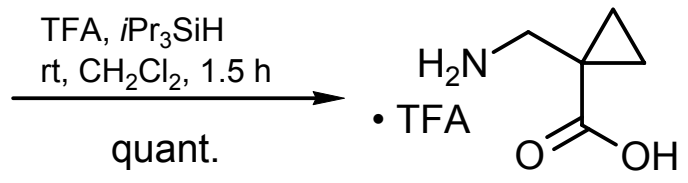

135

Scheme 58. Modification on known procedures to obtain 135.

The substrate 135 was supposed to be suitable for an intramolecular coupling between the free amino and the carboxylic functions. Typical strong coupling reactants like EDTA and HOAt promoted just the polymerization of $\mathbf{1 3 5}$, even working with a $0.02 \mathrm{M}$ solution of it or with a ten times more diluted solution. It was impossible to isolate any trace of the ring closure product 128 (Scheme 59). 


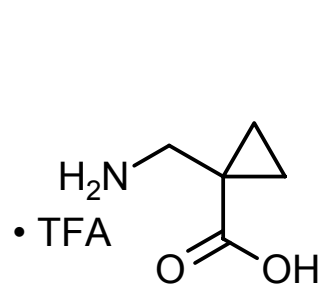

$135 \cdot$ TFA

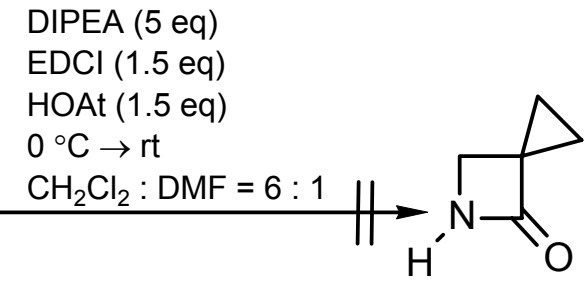

130

Scheme 59. Failed cyclization with coupling reagents.

Just the protection of $\mathbf{1 3 0}$ with a benzyl group, under a known procedure, ${ }^{[107]}$ to $\mathbf{1 3 8}$ and $\mathbf{1 3 9}$ (Scheme 60) and the subsequent Mukayama condensation protocol applied on $\mathbf{1 3 5},{ }^{[108]}$ gave finally the ring closure to $\mathbf{5 3 g}$ in a $51 \%$ yield, over two steps (Scheme 61).

1) $\mathrm{NEt}_{3}, \mathrm{rt}, \mathrm{EtOH}$

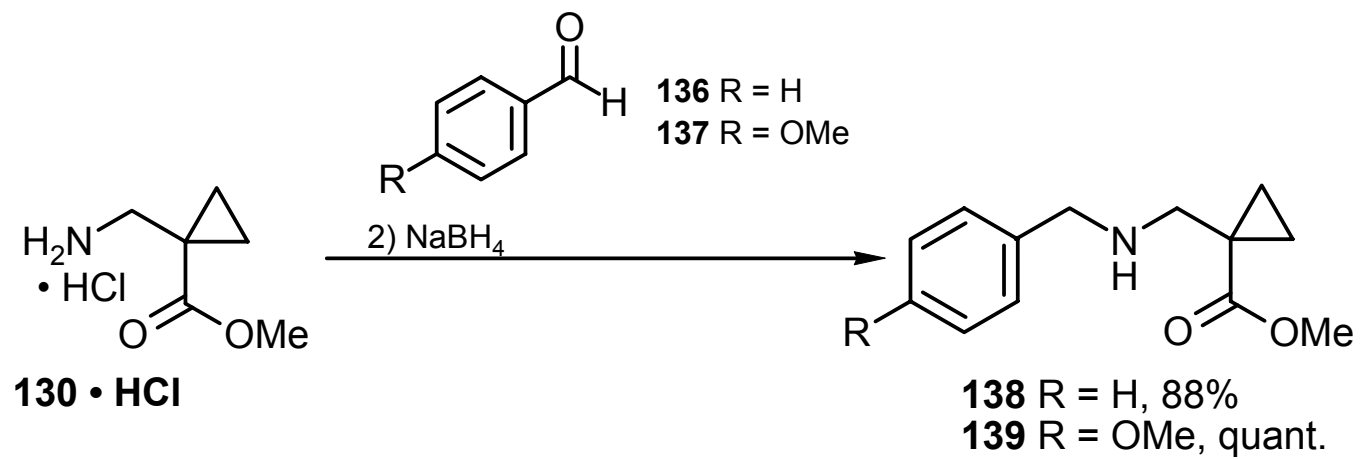

Scheme 60. Benzylic protection at the amino group in $\mathbf{1 3 0} \cdot \mathbf{H C l}$.

The procedure was not applied for the benzyl protected derivative 138, because problems correlated with the debenzylation of 5-benzyl-5-aza-spiro[2.3]hexan-4-one derivatives (Scheme 42 and 44, Chapter 4).

1) $\mathrm{NaOH}(1.0 \mathrm{M}), \mathrm{MeOH}$, reflux., $2 \mathrm{~h}$

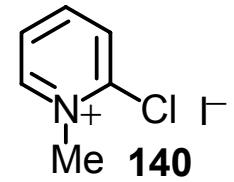<smiles>[R16]NCC1(C(=O)OC)CC1</smiles>

139
2) $\mathrm{NEt}_{3}, \mathrm{CH}_{2} \mathrm{Cl}_{2}, \mathrm{rt}, 12 \mathrm{~h}$

$51 \%$

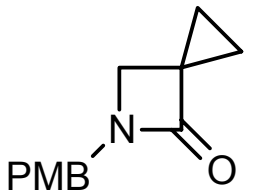

$53 \mathrm{~g}$

Scheme 61. Cyclization of the $N$-protected amino ester 139 under Mukajama's conditions. 
The long procedure could give just $\mathbf{5 3 g}$ and not directly the $\mathrm{N}$-deprotected spirocyclopropyl derivative 128. Moreover the deprotection step on a large scale presents some problem for the isolation of the product $\mathbf{1 2 8}$.

\subsection{Polymerizations}

Among polymerizable heterocyclic compounds, lactams represent the most versatile group. Polymerizable lactams include four and heigher-membered rings, which may be substituted both at the carbon atoms and at the amide nitrogen, or may contain other ring-atoms beside carbon and nitrogen. The different ring size and substitution affect very strongly the reactivity of lactams as well as the properties of the resulting polymer: polymers from four-membered lactams are close to polypeptides (i.e. polypropiolactam 124, Figure 23), and polymers from very large lactams approach the characteristics of polyethylene (i.e. polylaurolactam 141, Figure 26).

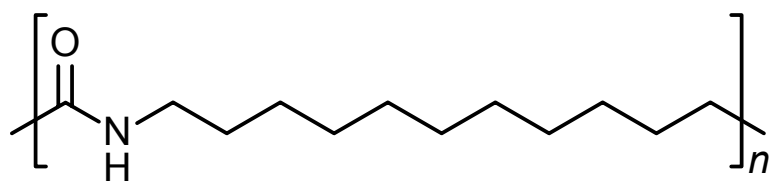

polylaurolactam 141

Figure 26. Polylactam with the properties of polyethylene.

Three different kinds of process are known: cationic, hydrolytic and anionic polymerization. ${ }^{[99]}$ The last one has been the most successfull in the field of $\beta$-lactams polymerization. ${ }^{[97,98,100]}$

The anionic ring opening polymerization consists in a chain-growth reaction, where are involved two activated species: the lactam anions 143a (particles of increased nucleophilicity) and $N$-acylated lactam units $142,144 b, 145 b$ etc. (i.e. growth centers of increasing acylating ability) (Scheme 62 and 63).

Lactams anions 143a are able to produce growth center and thus can initiate an anionic polymerization (Scheme 62). Therefore lactamates (i.e. salts of lactams in which the anion is 
derived from the lactam, like $\mathbf{1 4 3 a}$ or 126) and strong bases (e.g. $\mathrm{NaH}$, tert-BuOK) are designated initiators.

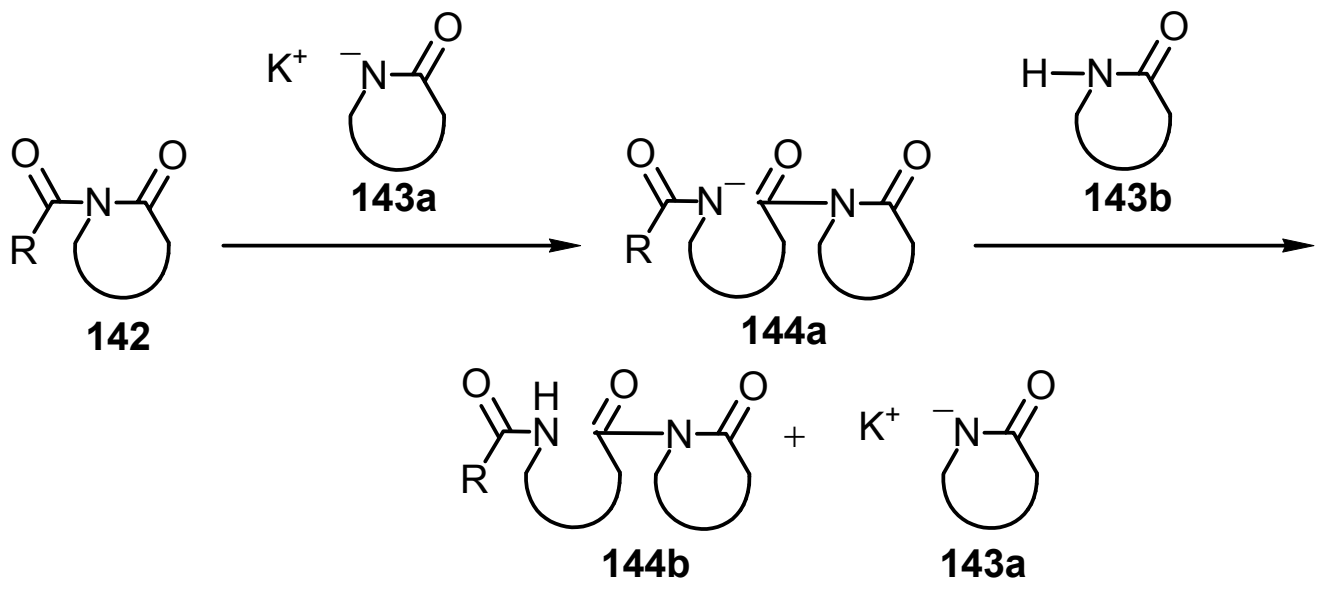

Scheme 62. Initiation step.

Acyl lactams or precursors of growth centers like 142 are termed activators, because they significantly enhance the effect of initiators. The polymerization proceeds through the nucleophilic attack of the lactamates on the monomeric unit $143 \mathrm{~b}$, to increase the chain length (Scheme 63).

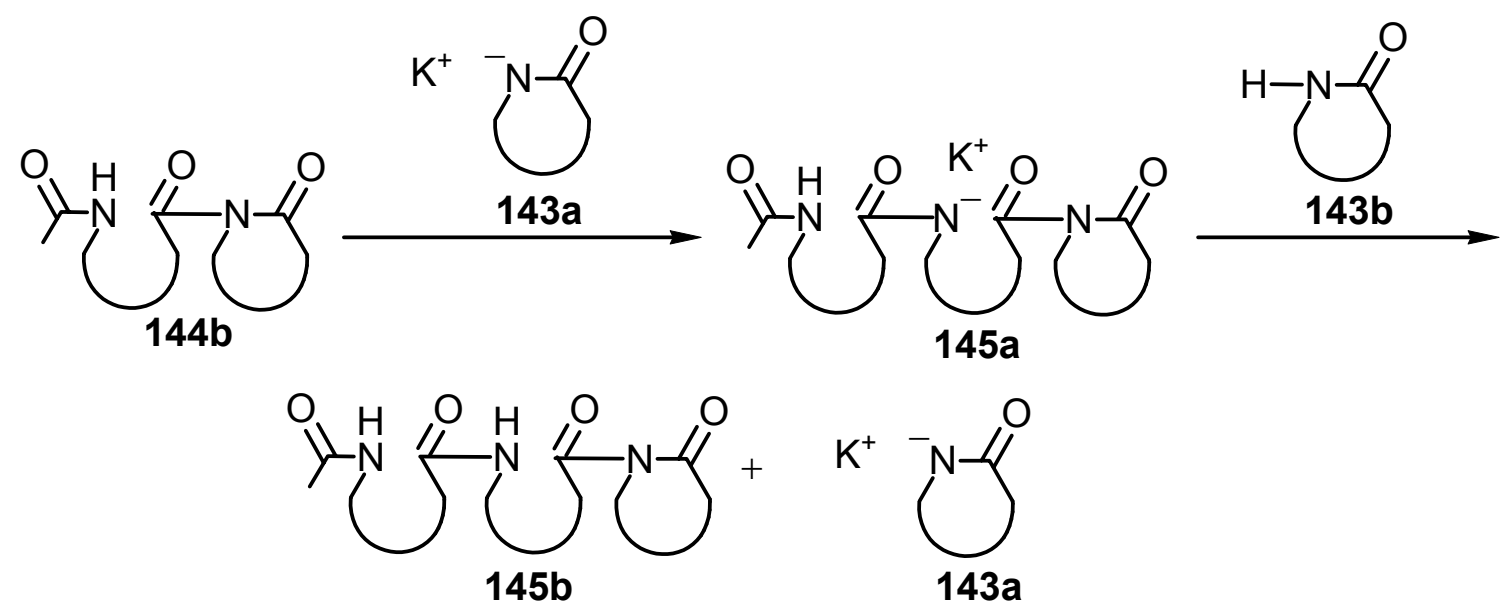

Scheme 63. Propagation step.

The work of Hashimoto on 4,4-dimethyl-2-azetidinone (147a) ${ }^{[98]}$ show the best results in terms of narrow molecular weight distribution for low-molecular weight poly( $\beta$-peptides) but already Graf et al., ${ }^{[85 \mathrm{a}]}$ Bestian $^{[85 \mathrm{~b}]}$ and Schmidt ${ }^{[87 \mathrm{a}]}$ studied the polymerization of a series of 2azetidinones and the properties of the resulting polymers. Their chemical resistence and melting temperature depend on the chain stereoregularity and on the nature of substituents. More recently, using a variety of initiators, the polymerization of 3-butyl-3-methyl-2- 
azetidinone 146d, ${ }^{[99]}$ of a series of 3-alkyl-3-methyl-2-azetidinones 146a-d, ${ }^{[97]}$ and of a series of 4-alkyl-4-methyl-2-azetidinones $\mathbf{1 4 7 a - d},{ }^{[109]}$ was reported, confirming the general behavior mentioned above (Figure 27).
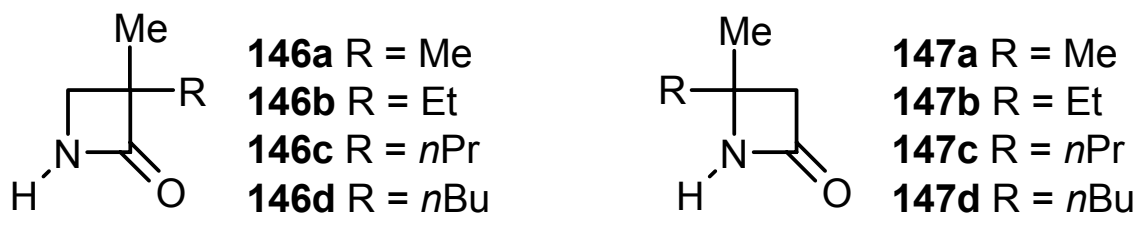

Figure 27. Derivatives on which has been tried the anionic polymerization.

\subsection{Synthesis and Characterization of New Poly(2-Azetidinones)}

Compound 108 and its benzoyl derivative 107d were prepared according to the oxidative process conducted on $\beta$-lactam 53d (Scheme 45, Chapter 4), while 4-Phenyl-2-azetidinone 148 and its benzoyl derivative 149 were prepared by following known procedures (Figure 28). ${ }^{[110]}$<smiles>N#CC1N(C(=O)[AlH2])C(=O)C12CC2</smiles><smiles>O=C1NCC1c1ccccc1</smiles>

148<smiles>N#CC1NC(=O)C12CC2</smiles><smiles>O=C1NCC12CC2</smiles>

128<smiles>O=C(c1ccccc1)N1CC(c2ccccc2)C1=O</smiles>

149

Figure 28. Monomers for the anionic polymerization.

The derivative 148 and the 3-spirocyclopropanated-2-azetidinones 108 and 128 , were subjected to polymerization-protocols, following the work of Hashimoto. ${ }^{[98]}$ The $\beta$-lactam 150 and the base catalyst $t \mathrm{BuOK}$ are stirred in the presence of the activator $\mathbf{1 5 1}$ and benzylamine is added to stop the process and get the polymer 153. Mild condition and dissolution of the polyamide during the process are achieved with a solution of lithium chloride in dry DMAA or DMF (Scheme 64). ${ }^{[98 \mathrm{a}]}$ 


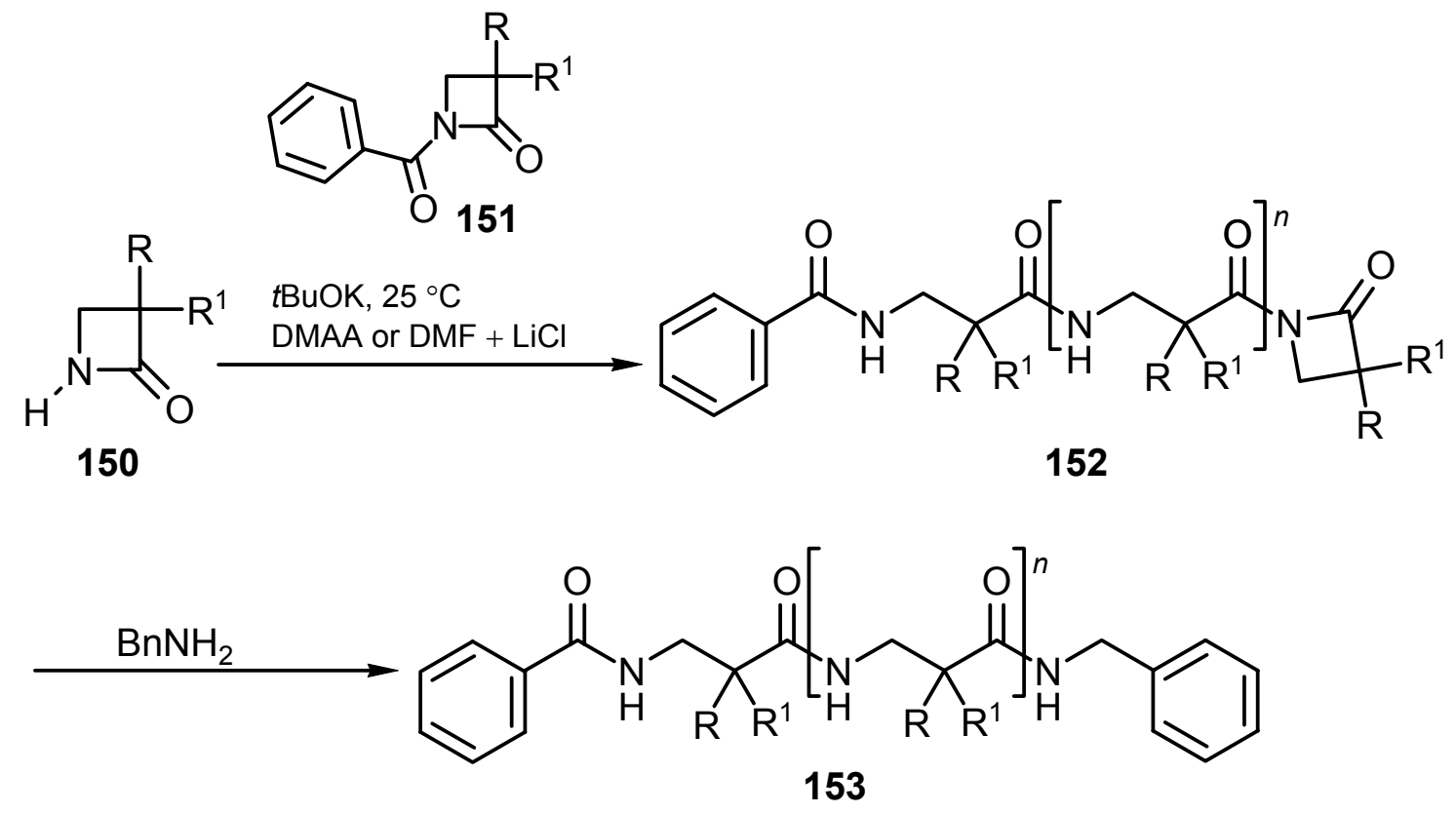

Scheme 64. Hashimoto conditions for the anionic polymerization of $\beta$-lactams.

The living anionic polymerization of 148 was tried ( $5 \mathrm{mmol}$ scale), using $\mathbf{1 4 9}$ as activator. The salt (5\% mol. respect to the starting material) was previously dried in vacuo at high temperature. Potassium tert-butoxide, freshly sublimated, was used as catalyst in small amount $(0.5 \%$ mol. $)$, to decrease the polymerization rate and with it the broadening of molecular weight distribution. The polymer was precipitated adding to the flask a mixture acetone/water 5:1 and purified and isolated through dissolution in trifluoroethanol and replicated precipitation with the same mixture of solvents. The powder was collected by centrifugation and shows a melting point higher than $260^{\circ} \mathrm{C}$.

The polymer IR spectrum shows respect to the monomer's one, a larger band for the free N-H stretching at $3291 \mathrm{~cm}^{-1}$ and the $\mathrm{C}=\mathrm{O}$ strong band has moved from $1745 \mathrm{~cm}^{-1}$ (typical value for a $\beta$-lactam amidic carbonyl) to $1648 \mathrm{~cm}^{-1}$, with a second strong band at $1528 \mathrm{~cm}^{-1}$, that is characteristic of polyamides.

The ESI mass spectrum shows a regular distribution of peaks, and this confirms the formation of a totally new poly- $\beta$-peptide. It's possible to find peacks every $146 \mathrm{~m} / \mathrm{z}$ and $294 \mathrm{~m} / \mathrm{z}$, corresponding respectively at the molecular weight of one and two monomers. The maximum observed value corresponds to 945 , the molecular weight of $\mathbf{1 5 4}$, in which four monomerunits $(n=4)$ are bound with an initiator molecule and a benzyl rest at the chain end (Figure 29). 


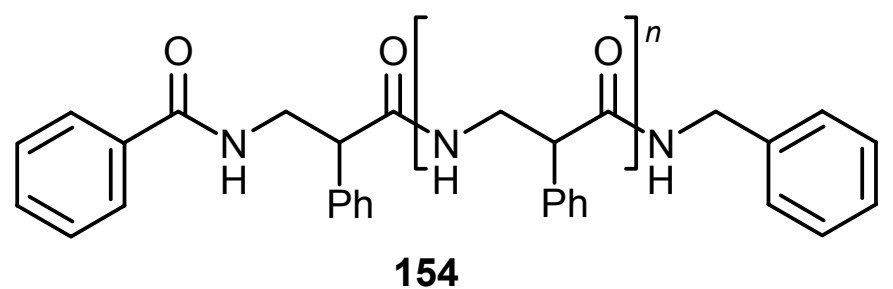

Figure 29. Polymerization product 154 .

In the case of compound $\mathbf{1 0 8}$ dry dimethylacetamide was used as solvent, toghether with lithium chloride, previously dried in vacuo. The mixture acetone/water, used for 148, could not precipitate the polymer and diethyl ether was used. After purification, a white powder was collected via centrifugation. Its IR spectrum shows a large band for the free N-H $\left(3273 \mathrm{~cm}^{-1}\right)$ but the $\beta$-lactamic $\mathrm{C}=\mathrm{O}$ stretch $\left(1753 \mathrm{~cm}^{-1}\right)$ is not completely disappeared from the spectrum, although it seems like a shoulder of the bigger band by $1672 \mathrm{~cm}^{-1}$, due to acyclic amidic $\mathrm{C}=\mathrm{O}$.

The polymer was not soluble in the solvent suitable for the ESI measurement, so that it does not really represent the mass distributions for the polymer but just the soluble impurities, collected during the procedures that allow the polymer isolation. Also attempts to determine the molecular weight distribution with GPC failed for the same reason.

A last attempt was tried with 128. A solution of lithium chloride in dry dimethyl acetamide was used as the solvent and freshly sublimated potassium tert-butoxide was used as the catalyst. No acylated-activator was added to the flask. The mixture acetone/water could precipitate the polymer, that was treated like as usual for purification and isolation.

The polymer IR spectrum shows that the amidic carbonyl strong band, typical for $\beta$-lactams, has moved to $1635 \mathrm{~cm}^{-1}$, with a second strong band by $1576 \mathrm{~cm}^{-1}$, that is characteristic of polyamides.

Even if the IR measurements give positive results, no full characterization was possible for the polymers obtained from $\mathbf{1 2 8}$, as well as for $\mathbf{1 0 8}$, because the isolated solids were impossible to solve for the necessary spectral analysis (NMR, mass spectrometry, Gel Permeation Cromatography).

The low solubility is a quite common property of polyamides ${ }^{[98 \mathrm{a}]}$ but, in the presence of reactive groups like the strained cyclopropyl ring or the nitrile, could also derive from reaction between different formed chains.

Probably, the used conditions cannot avoid reactions between different chains, expecially because of the presence of the strained small ring or of the nitrile group. This phenomenon could explain the practical impossibility to dissolve again the isolated polymers. 


\section{Experimental Part}

\section{General Notes}

IR: Bruker IFS 66 (FT-IR) spectrophotometer, measured as $\mathrm{KBr}$ pellets or oils between $\mathrm{KBr}$ plates. - NMR spectra were recorded on a Bruker AM $250\left(250 \mathrm{MHz}\right.$ for ${ }^{1} \mathrm{H}$ and $62.9 \mathrm{MHz}$ for ${ }^{13} \mathrm{C}$ NMR), a Varian Mercury $200\left(200 \mathrm{MHz}\right.$ for ${ }^{1} \mathrm{H}$ and $50.3 \mathrm{MHz}$ for ${ }^{13} \mathrm{C}$ NMR), a Unity $300\left(300 \mathrm{MHz}\right.$ for ${ }^{1} \mathrm{H}$ and $75.5 \mathrm{MHz}$ for $\left.{ }^{13} \mathrm{C} \mathrm{NMR}\right)$ and an Inova $600\left(600 \mathrm{MHz}\right.$ for ${ }^{1} \mathrm{H}$, $150 \mathrm{MHz}$ for ${ }^{13} \mathrm{C} \mathrm{NMR}$ ) instruments in $\mathrm{CDCl}_{3}$ if not otherwise specified. Multiplicities were determined by DEPT (Distortionless Enhancement by Polarization Transfer) or APT (Attached Proton Test) measurements. The signals were characterized: $\mathrm{s}=$ singlet, $\mathrm{bs}=$ broad singlet, $\mathrm{d}=$ doublet, $\mathrm{t}=$ triplet, $\mathrm{q}=$ quartet, $\mathrm{dd}=$ double of doublets, $\mathrm{ddd}=$ double of $\mathrm{dd}$, $\mathrm{dt}=$ double of triplets, $\mathrm{m}=$ multiplet, $\mathrm{cPr}-\mathrm{H}=$ cyclopropyl proton, $\mathrm{cHex}-\mathrm{H}=$ cyclohexyl proton, $\mathrm{Ar}-\mathrm{H}=$ aromatic proton, $*=$ the assignment is exchangeable. The signals were characterized: $+=$ primary or tertiary (positive DEPT-signal), $-=$ secondary (negative DEPTsignal), $\mathrm{C}_{\text {quat }}=$ quaternary carbon atom (zero DEPT-signal) or $+=$ primary or tertiary (positive APT-signal), $-=$ secondary or quaternary carbon atom (negative APT-signal). The signals were characterized: $\mathrm{cPr}-\mathrm{C}=$ cyclopropyl carbon, $\mathrm{cHex}-\mathrm{C}=$ cyclohexyl carbon, Ar$\mathrm{C}=$ aromatic carbon, $*=$ the assignment is exchangeable. $-\mathrm{MS}$ (EI, $70 \mathrm{eV}$ ) or DCI (with $\mathrm{NH}_{3}$ ): Finnigan MAT 95 spectrometer. High resolution mass data (HRMS) were obtained by preselected-ion peak matching at $R$ ca. 10000 to be within \pm 2 ppm of the exact mass, ESI: APEX IV 7T FTICR Brucker Daltonic. - M.p.: melting point instrument according to Dr Tottoli: Büchi 510 capillary melting point apparatus, uncorrected values. - TLC: MachereyNagel precoated sheets, $0.25 \mathrm{~mm}$ Sil G/UV 254 , developed with molybdenum phosphoric acid solution (10\% in ethanol), ninhydrine (300 mg ninhydrine, $3.00 \mathrm{~g}$ acetic acid, $100 \mathrm{~mL}$ nbutanol) or iodine. - Column chromatography: Merck silica gel, grade 60, 70-230 or 230400 mesh. - Elemental analysis: Mikroanalytisches Laboratorium des Instituts für Organische und Biomolekulare Chemie der Universität Göttingen, Germany. - X-Ray structure analysis of compounds $47 \mathbf{a}, \mathbf{1 0 7} \mathbf{b}$, and $\left[\left(2 S, 2^{\prime} R\right)-118\right]$ were collected at 133(2) $\mathrm{K}$ on a STOE-IPDS 2 Image Plate diffractometer using graphite monochromated $\mathrm{Mo}-\mathrm{K}_{\alpha}$ radiation. The structure solutions and refinements on $\mathrm{F}^{2}$ were performed with the Bruker SHELXTL program suite. Microwave: the reactions under microwave heating were carried out in a Smith Creator, part 
of Coherent SynthesisTM, Personal Chemistry. Emission frequency of $2.45 \mathrm{GHz}$ and reactor with on-line temperature, pressure and microwave power control. Reaction temperature in the range of 60 to $250{ }^{\circ} \mathrm{C}$, reaction pressures up to $2 \mathrm{MPa}$ (20 bar). The temperature increase varies in the range $2-5{ }^{\circ} \mathrm{C} / \mathrm{sec}$, depending on the solvent. The reactions are performed under magnetic stirring, in vials with caps supplied by Personal Chemistry. - Solvents were dried and purified according to conventional laboratory methods under Argon atmosphere. All chemicals were used as commercially available, unless otherwise noted. - Abbreviations: $\mathrm{Ac}=$ acetate,$\quad \mathrm{Ar}=$ aryl,$\quad \mathrm{HOAt}=7$-aza-1-hydroxybenzotriazole,$\quad \mathrm{Bn}=$ benzyl, $\mathrm{Bnh}=$ benzhydryl, $\mathrm{Boc}=$ tertbutoxycarbonyl, $t \mathrm{Bu}=$ tertbutyl, $\mathrm{Bz}=$ benzoyl,$m \mathrm{CPBA}=$ metachloroperbenzoic acid, $\mathrm{cHex}=$ cyclohexyl, DEAD $=$ diethylazodicarboxylate, $\mathrm{DMAA}=N, N-$ dimethylacetamide, $\quad \mathrm{DMAP}=N, N$-dimethylaminopyridine,$\quad \mathrm{DMF}=$ dimethylformamide, $\mathrm{EE}=$ ethoxy-ethoxy, $\mathrm{Et}=$ ethyl,, $\mathrm{Me}=$ methyl, $\mathrm{MeCN}=$ acetonitrile, $\mathrm{Ph}=$ phenyl, $\mathrm{PMB}=4-$ methoxybenzyl, THF $=$ tetrahydrofurane, TIPS $=$ triisopropylsilyl. The following substances were prepared according to literature procedures: biciclopropylidene (24), ${ }^{[18]}$ methylenecyclopropane (43), ${ }^{[18]} \quad N$-benzyl-C-phenylnitrone (44a), ${ }^{[4]} \quad N$-benzyl-C-(methoxycarbonyl)nitrone (44b), ${ }^{[44]} N$-benzyl-C-cyanonitrone $(44 \mathbf{c}),{ }^{[43]} N$ - $(p$-methoxybenzyl)-methyleneammine $N$-oxide $(\mathbf{4 4 g}),{ }^{[45]} \quad$ formaldehyde- $N$-benzyloxime $(\mathbf{4 4 j}),{ }^{[46]}$ dispiro[cyclopropane-1,2'hexahydropyrrolo[1,2-b]isoxazole-3,1" -cyclopropane $](\mathbf{7 0}),{ }^{[50]}$ benzylhydroxylamine oxalate $\left(65 \mathbf{c} \cdot(\mathbf{C O O H})_{2}\right),{ }^{[43]}$ benzhydrylhydroxylamine hydrochloride $(65 e \cdot \mathbf{H C l}),{ }^{[43]}$ cyclohexylglyoxylate (73-cHex) and methylglyoxylate $(73-\mathrm{Me}),{ }^{[63]}$ phenylhydroxylamine hydrochloride $(\mathbf{6 5 h} \cdot \mathbf{H C l}), 4$-bromophenylhydroxylamine hydrochloride $(65 \mathbf{6 i} \cdot \mathbf{H C l}),{ }^{[60]}$ 5-Methyl-6phenyl-5-azaspiro[2.3] hexan-4-one $(\mathbf{5 3 f}),{ }^{[65]}$ tertbutylglycinate $(\mathbf{1 0 2}),{ }^{[111]}$ 4-Phenyl-2-azetidinone (148). ${ }^{[110]}$ 


\section{Procedures for the Synthesis and Spectral Data of the Compounds}

\subsection{Synthesis of the Compounds in Chapter 1}

$\boldsymbol{N}$-(p-Methoxybenzyl)- $\boldsymbol{C}$-cyanonitrone (44d): Chloroacetonitrile (22.6 g, $18.9 \mathrm{~mL}, 0.30 \mathrm{~mol})$ and $\mathrm{K}_{2} \mathrm{CO}_{3}(55.3 \mathrm{~g}, 0.40 \mathrm{~mol})$ were added to a vigorously stirred solution of<smiles>COc1ccc(C[N+]([O-])=CC#N)cc1</smiles>
p-methoxybenzylamine $(27.4 \mathrm{~g}, 26.1 \mathrm{~mL}, 0.20 \mathrm{~mol})$ in acetonitrile $(2 \mathrm{~L})$. After an additional stirring for $12 \mathrm{~h}$ at $60^{\circ} \mathrm{C}$, the suspension was filtered through a pad of Celite, and the solvent was evaporated under reduced pressure. The residue was purified by column chromatography $\left(R_{\mathrm{f}}=0.20\right.$, $660 \mathrm{~g}$ of silica gel, $7.5 \times 20 \mathrm{~cm}$ column, hexane $\left./ \mathrm{Et}_{2} \mathrm{O} 1: 2\right)$ to give 44d $(28.0 \mathrm{~g}, 80 \%)$ as a dark oil. To the solution of the latter $(28.0 \mathrm{~g}$, $0.160 \mathrm{~mol})$ in anhydrous $\mathrm{CH}_{2} \mathrm{Cl}_{2}(760 \mathrm{~mL})$ was added $m$ CPBA $(60.7 \mathrm{~g}, 0.352 \mathrm{~mol})$ in small portions at $0{ }^{\circ} \mathrm{C}$. After an additional stirring for $30 \mathrm{~min}$ at $0{ }^{\circ} \mathrm{C}$ and for $1 \mathrm{~h}$ at ambient temperature, a $10 \%$ aq. solution of $\mathrm{Na}_{2} \mathrm{~S}_{2} \mathrm{O}_{3}(300 \mathrm{~mL})$ and sat. aq. $\mathrm{NaHCO}_{3}$ solution $(300 \mathrm{~mL})$ were added, and the mixture was stirred for an additional $1 \mathrm{~h}$. The aqueous phase was extracted with $\mathrm{CH}_{2} \mathrm{Cl}_{2}(2 \times 200 \mathrm{~mL})$; the combined organic layers were washed with brine $(2 \times 200 \mathrm{~mL})$, dried and concentrated under reduced pressure. Nitrone $44 \mathrm{~d}(30.4 \mathrm{~g}, 100 \%, 1: 4$ mixture of $E$ - and $Z$-isomers) was obtained as a yellow solid and used without purification. An analytical sample was obtained by column chromatography $\left(R_{\mathrm{f}}=0.24,20 \mathrm{~g}\right.$ of silica gel, $2 \times 13 \mathrm{~cm}$ column, hexane $/ \mathrm{Et}_{2} \mathrm{O}$ 1:3); m.p. $74-75^{\circ} \mathrm{C}$. $-\mathrm{IR}(\mathrm{KBr}): \tilde{v}=3102 \mathrm{~cm}^{-1}, 2994,2964$, 2937, 2838, 2222, 1616, 1587, 1544, 1520, 1462, 1414. - ${ }^{1} \mathrm{H}$ NMR (250 MHz, $\left.\mathrm{CDCl}_{3}\right)$ : $\delta=3.82\left(\mathrm{~s}, 3 \mathrm{H}, \mathrm{OCH}_{3}, E\right.$-isomer), $3.84\left(\mathrm{~s}, 3 \mathrm{H}, \mathrm{OCH}_{3}, Z\right.$-isomer), 4.94 (s, $2 \mathrm{H}, \mathrm{CH}_{2}, Z$ isomer), $5.24\left(\mathrm{~s}, 2 \mathrm{H}, \mathrm{CH}_{2}, E\right.$-isomer), $6.53(\mathrm{~s}, 1 \mathrm{H},=\mathrm{CH}, Z$-isomer $), 6.62(\mathrm{~s}, 1 \mathrm{H},=\mathrm{CH}, E$ isomer), 6.90-6.99 (m, $4 \mathrm{H}, \mathrm{Ar}-\mathrm{H}, \mathrm{Z}$ - and $E$-isomers), 7.29-7.33 (m, $2 \mathrm{H}, \mathrm{Ar}-\mathrm{H}, \mathrm{Z}$-isomer), 7.44-7.48 (m, $2 \mathrm{H}, \mathrm{Ar}-\mathrm{H}, E$-isomer). $-{ }^{13} \mathrm{C} \mathrm{NMR}\left(50.3 \mathrm{MHz}, \mathrm{CDCl}_{3}\right.$, additional DEPT): $\delta=55.3\left(+, \mathrm{CH}_{3}, E\right.$-isomer), 55.4 ( $+, \mathrm{CH}_{3}, Z$-isomer), 69.4 (-, $\mathrm{CH}_{2}, E$-isomer $), 71.1$ (-, $\mathrm{CH}_{2}$, $Z$-isomer), 106.8 (+, = $\mathrm{CH}, Z$-isomer), $107.0\left(+,=\mathrm{CH}, E\right.$-isomer), 112.1 ( $\mathrm{C}_{\text {quat }}, \mathrm{CN}, Z$-isomer), $114.3(+, 2 \mathrm{CH}, \mathrm{Ar}-\mathrm{C}, E$-isomer), 114.8 (+, $2 \mathrm{CH}, \mathrm{Ar}-\mathrm{C}, Z$-isomer $), 115.3\left(\mathrm{C}_{\text {quat }}, \mathrm{CN}, E-\right.$ isomer), 122.4 ( $\mathrm{C}_{\text {quat }}, \mathrm{Ar}-\mathrm{C}, \mathrm{Z}$-isomer), 123.5 ( $\mathrm{C}_{\text {quat }}, \mathrm{Ar}-\mathrm{C}, E$-isomer $), 131.0$ (+, $2 \mathrm{CH}, \mathrm{Ar}-\mathrm{C}$, E-isomer), 131.5 (+, 2 CH, Ar-C, Z-isomer), 160.7 (C quat $_{\text {, }} \mathrm{Ar}-\mathrm{C}, E$-isomer $), 161.0$ (C $\mathrm{C}_{\text {quat }}, \mathrm{Ar}-\mathrm{C}$, $Z$-isomer). - MS (EI): $m / z(\%)=190$ (2) $\left[\mathrm{M}^{+}\right], 121$ (100), 77 (12), 51 (8). - $\mathrm{C}_{10} \mathrm{H}_{10} \mathrm{~N}_{2} \mathrm{O}_{2}$ (190.2): calcd. C 63.15, H 5.30, N 14.73; found C 62.88, H 5.49, N 14.93. 
$N$-(p-Methoxybenzyl)hydroxylamine oxalate (65d): To a solution of $N$-( $p$-methoxybenzyl)-<smiles>COc1ccc(CNO)cc1</smilesC-cyanonitrone 44d $(4.70 \mathrm{~g}, 25.0 \mathrm{mmol})$ in $\mathrm{MeOH}(125 \mathrm{~mL})$ was added $\mathrm{NH}_{2} \mathrm{OH} \cdot \mathrm{HCl}(8.70 \mathrm{~g}, 125 \mathrm{mmol})$. After stirring for 2 $\mathrm{h}$ at $60{ }^{\circ} \mathrm{C}$, the resulting mixture was cooled to r.t., methanol was evaporated in vacuo, and $\mathrm{CHCl}_{3}(100 \mathrm{~mL})$ was added. The mixture containing some undissolved solids was filtered through a pad of Celite. The filtrate was concentrated, and the residue was partitioned with $\mathrm{CHCl}_{3}(150 \mathrm{~mL})$ and a satd. solution of $\mathrm{NaHCO}_{3}(150 \mathrm{~mL})$. The acqueous layer was extracted with $\mathrm{CHCl}_{3}(2 \times 70 \mathrm{~mL})$, and the combined extracts were washed with satd. solution of $\mathrm{NaCl}(150 \mathrm{~mL})$, dried $\left(\mathrm{MgSO}_{4}\right)$ and filtered. To the filtrate was added a solution of oxalic acid $(3.15 \mathrm{~g}, 250.0 \mathrm{mmol})$ in $25 \mathrm{~mL}$ of methanol, and the resulting suspension was evaporated to dryness. The solid obtained was triturated with ether/pentane, and collected by suction. After drying in vacuo, analytically pure 65d (4.84 g, 80\%) was obtained as a yellowish solid, m.p. $145^{\circ} \mathrm{C} .-\mathrm{IR}(\mathrm{KBr}): \tilde{v}=3424$ $\mathrm{cm}^{-1}, 2932,2837,1721,1612,1515,1454,1306,1253,826,710 .-{ }^{1} \mathrm{H}$ NMR $(250 \mathrm{MHz}$, $\left.\mathrm{CD}_{3} \mathrm{OD}\right): \delta=3.85\left(\mathrm{~s}, 3 \mathrm{H}, \mathrm{CH}_{3}\right), 4.35\left(\mathrm{~s}, 2 \mathrm{H}, \mathrm{CH}_{2}\right), 7.01-7.05(\mathrm{~m}, 2 \mathrm{H}, \mathrm{Ar}-\mathrm{H}), 743-7.47$ (m, $2 \mathrm{H}, \mathrm{Ar}-\mathrm{H}) .-{ }^{13} \mathrm{C}$ NMR $\left(62.9 \mathrm{MHz}, \mathrm{CD}_{3} \mathrm{OD}\right.$, additional DEPT): $\delta=56.0\left(+, \mathrm{CH}_{3}\right), 56.4(-$, $\left.\mathrm{CH}_{2}\right), 115.7$ (+, $\left.2 \mathrm{CH}, \mathrm{Ar}-\mathrm{C}\right), 122.1$ ( $\left.\mathrm{C}_{\text {quat }}, \mathrm{Ar}-\mathrm{C}\right), 133.6$ (+, $\left.2 \mathrm{CH}, \mathrm{Ar}-\mathrm{C}\right), 162.1\left(\mathrm{C}_{\text {quat }}, \mathrm{Ar}-\mathrm{C}\right)$, $165.5\left(\mathrm{C}=\mathrm{O},(\mathrm{COOH})_{2}\right) .-\mathrm{C}_{10} \mathrm{H}_{13} \mathrm{NO}_{6}$ (243.22): calcd. $\mathrm{C}$ 49.38, H 5.39, N 5.76; found $\mathrm{C}$ 49.13, H 5.61, N 5.90.

$N$-(p-Methoxybenzyl)- $\boldsymbol{C}$-(2-iodophenyl)-nitrone (44f): To a suspension of $p$-methoxy-<smiles>COc1ccc(C/[N+]([O-])=C/c2ccccc2I)cc1</smilesbenzylhydroxylamine oxalate $\mathbf{6 5 d} \cdot(\mathbf{C O O H})_{2}(1.19 \mathrm{~g}$, $4.90 \mathrm{mmol})$ and triethylamine $(0.496 \mathrm{~g}, \quad 0.68 \mathrm{~mL}$, $4.90 \mathrm{mmol})$ in dry THF $(25 \mathrm{~mL})$ was added $o$-Iodobenzaldehyde $(1.14 \mathrm{~g}, 4.90 \mathrm{mmol})$. After an additional stirring for 36 hours at $25^{\circ} \mathrm{C}$ in the presence of molecular sieves, diethyl ether was added $(25 \mathrm{~mL})$ and the suspension was filtered through a pad of Celite ${ }^{\circledR}$. Water $(40 \mathrm{~mL})$ was added and the phases were separated. The aqueous phase was extracted with ether $(2 \times 50 \mathrm{~mL})$; the combined organic layers were washed with $\mathrm{HCl} 2 \mathrm{M}(2 \times 100 \mathrm{~mL})$, dried and concentrated under reduced pressure. The nitrone $44 \mathrm{f}(1.60 \mathrm{~g}, 89 \%)$ was obtained as a yellow solid, m.p. $81-82{ }^{\circ} \mathrm{C}$. - IR (KBr): $\tilde{v}=3060 \quad \mathrm{~cm}^{-1}, 2935,2838,1516,1290,1248,1033 . \quad-{ }^{1} \mathrm{H}$ $\operatorname{NMR}\left(250 \mathrm{MHz}, \mathrm{CDCl}_{3}\right): \delta=3.79\left(\mathrm{~s}, 3 \mathrm{H}, \mathrm{CH}_{3} \mathrm{O}\right), 4.99\left(\mathrm{~s}, 2 \mathrm{H}, \mathrm{CH}_{2}\right), 6.92-7.04(\mathrm{~m}, 3 \mathrm{H}, \mathrm{Ar}-$ H), 7.33-7.43 (m, 3 H, Ar-H), 7.70 (s, $1 \mathrm{H},=\mathrm{CH}), 7.82-7.85$ (m, $1 \mathrm{H}, \mathrm{Ar}-\mathrm{H}), 9.14-9.17$ (m, 1 $\mathrm{H}, \mathrm{Ar}-\mathrm{H}) .-{ }^{13} \mathrm{C} \mathrm{NMR}\left(62.9 \mathrm{MHz}, \mathrm{CDCl}_{3}\right.$, additional DEPT): $\delta=53.3\left(+, \mathrm{CH}_{3}\right), 71.2(-$, 
$\left.\mathrm{NCH}_{2}\right), 99.3$ ( $\left.\mathrm{C}_{\text {quat }}, \mathrm{Ar}-\mathrm{C}\right), 114.3(+, 2 \mathrm{CH}, \mathrm{Ar}-\mathrm{C}), 124.8\left(\mathrm{C}_{\text {quat }}, \mathrm{Ar}-\mathrm{C}\right), 128.2(+, \mathrm{CH}, *), 129.0$ $(+, \mathrm{CH}, *), 131.0(+, 2 \mathrm{CH}, \mathrm{Ar}-\mathrm{C}), 131.3\left(+, \mathrm{CH},{ }^{*}\right), 132.1\left(\mathrm{C}_{\text {quat }}, \mathrm{Ar}-\mathrm{C}\right), 137.3(+, \mathrm{CH}, *)$, $139.4(+, \mathrm{CH}, *), 160.1\left(\mathrm{C}_{\text {quat }}, \mathrm{Ar}-\mathrm{C}\right) . \mathrm{MS}(\mathrm{EI}): \mathrm{m} / z(\%)=367$ (2) $\left[\mathrm{M}^{+}\right], 351$ (2), 232 (2), 203 (1), 121 (100), 91 (4), 77 (4). - $\mathrm{C}_{15} \mathrm{H}_{14} \mathrm{INO}_{2}$ (367.18): calcd. C 49.07, H 3.84, N 3.81; found C 48.84, H 3.82, N 3.72.

N-Benzyl-C-(Cyclohexyloxycarbonyl)-nitrone (44i): $\quad$ Cyclohexylglyoxylate $\quad(0.687 \mathrm{~g}$,<smiles>COc1ccc(C/C=[N+](\[O-])C(=O)OC2CCCCC2)cc1</smiles>
$4.40 \mathrm{mmol}$ ) was added to a solution of benzylhydroxylamine $65 \mathrm{c}(0.448 \mathrm{~g}, 3.64 \mathrm{mmol})$ in benzene $(19 \mathrm{~mL})$. After refluxing for $14 \mathrm{~h}$, the solvent was evaporated under reduced pressure. The residue was purified by column chromatography $\left(R_{\mathrm{f}}=0.17,85 \mathrm{~g}\right.$ of silica gel, $3.5 \times 18 \mathrm{~cm}$ column, hexane/ $\left.\mathrm{Et}_{2} \mathrm{O} 2: 1\right)$ to give $44 \mathbf{i}(0.723 \mathrm{~g}, 76 \%, 1: 1.8$ mixture of $E$ - and $Z$ - isomers $)$ as a colorless solid with m.p. $69-70{ }^{\circ} \mathrm{C}$. - IR (KBr): $\tilde{v}=3072 \mathrm{~cm}^{-1}, 2937,2857,1717,1559,1261,1018$. ${ }^{1} \mathrm{H}$ NMR $\left(250 \mathrm{MHz}, \mathrm{CDCl}_{3}\right.$ ): $\delta=1.25-1.90$ (m, $20 \mathrm{H}, \mathrm{cHex}-\mathrm{H}, E$ - and $Z$ - isomers), 4.82-4.85 (m, $2 \mathrm{H}, \mathrm{OcHex}-\mathrm{H}, E$ - and $Z$ - isomers), 4.98 (s, $2 \mathrm{H}, \mathrm{NCH}_{2}, Z$-isomer), 5.70 (s, $2 \mathrm{H}, \mathrm{NCH}_{2}, E$ isomer), $7.04(\mathrm{~s}, 1 \mathrm{H},=\mathrm{CH}, Z$-isomer $), 7.18(\mathrm{~s}, 1 \mathrm{H},=\mathrm{CH}, E$-isomer $), 7.31-7.43(\mathrm{~m}, 6 \mathrm{H}, \mathrm{Ar}$ $\mathrm{H}, E$ - and Z- isomers), 7.51-7.59 (m, $4 \mathrm{H}, \mathrm{Ar}-\mathrm{H}, E$ - and $Z$ - isomers). $-{ }^{13} \mathrm{C} \mathrm{NMR}(62.9 \mathrm{MHz}$, $\mathrm{CDCl}_{3}$, additional APT): $\delta=23.6\left(-, 2 \mathrm{CH}_{2}, \mathrm{cHex}-\mathrm{C}, E\right.$ - and $Z$ - isomers $), 25.1\left(-, \mathrm{CH}_{2}, \mathrm{cHex}-\right.$ C, $Z$-isomer), 25.2 (-, $\mathrm{CH}_{2}$, cHex-C, E-isomer), 31.2 (-, $2 \mathrm{CH}_{2}, \mathrm{cHex}-\mathrm{C}, E$-isomer), 31.4 (-, 2 $\mathrm{CH}_{2}$, cHex-C, Z-isomer), 66.1 (-, $\mathrm{NCH}_{2}, Z$-isomer), 73.1 (-, $\mathrm{NCH}_{2}, E$-isomer), 73.4 (+, $\mathrm{OCH}$, cHex-C, E-isomer), 74.2 (+, OCH, cHex-C, Z-isomer), 125.7 (+, =CH, E-isomer), 127.5 (+, $=\mathrm{CH}, Z$-isomer), 128.5 (+, $2 \mathrm{CH}, \mathrm{Ar}-\mathrm{C}, \mathrm{Z}$-isomer), 128.7 (+, $2 \mathrm{CH}, \mathrm{Ar}-\mathrm{C}, E$-isomer), 129.0 (+, $2 \mathrm{CH}, \mathrm{Ar}-\mathrm{C}, E$-isomer), 129.2 (+, $2 \mathrm{CH}, \mathrm{Ar}-\mathrm{C}, \mathrm{Z}$-isomer), 129.4 (+, $\mathrm{CH}, \mathrm{Ar}-\mathrm{C}, E$-isomer), 129.6 ( $+, \mathrm{CH}, \mathrm{Ar}-\mathrm{C}, \mathrm{Z}$-isomer), 131.6 (-, $\mathrm{C}_{\text {quat }}, \mathrm{Ar}-\mathrm{C}, \mathrm{E}$-isomer), 133.3 (-, $\mathrm{C}_{\text {quat, }}$ Ar-C, Zisomer), 159.3 (-, $\mathrm{C}_{\text {quat }}, \mathrm{C}=\mathrm{O}, E$-isomer), 160.3 (-, $\mathrm{C}_{\text {quat }}, \mathrm{C}=\mathrm{O}, Z$-isomer). - MS (EI): $m / z(\%)=261(10)\left[\mathrm{M}^{+}\right], 244(2), 162(12), 91$ (100), 83 (14), 65 (8), 55 (12).

\section{Cycloaddition of Nitrones 44a-g to Bicyclopropylidene (24). General Procedure 1.}

(GP 1) : A solution of the respective nitrone $(5 \mathrm{mmol})$ and bicyclopropylidene (24) $(0.85 \mathrm{~g}$, $1.0 \mathrm{~mL}, 10.6 \mathrm{mmol}$ ) was stirred in a hermetically closed tube at the indicated temp. for the indicated time. After cooling to ambient temp., the solution was concentrated under reduced pressure, and the crude product was purified by column chromatography on silica gel. 
8-Benzyl-9-phenyl-7-oxa-8-azadispiro[2.0.2.3]nonane (47a): Column chromatography

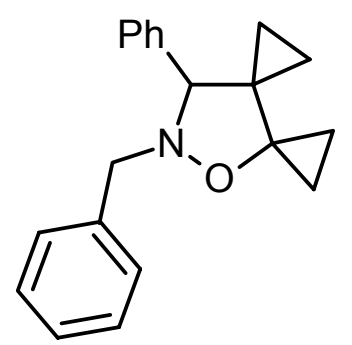

$\left(R_{\mathrm{f}}=0.44,165 \mathrm{~g}\right.$ of silica gel, $5 \times 17 \mathrm{~cm}$ column, hexane $\left./ \mathrm{Et}_{2} \mathrm{O} 10: 1\right)$ of the residue obtained from nitrone $44 \mathrm{a}(3.76 \mathrm{~g}, 18.0 \mathrm{mmol})$ and bicyclopropylidene $24(1.60 \mathrm{~g}, 1.87 \mathrm{~mL}, 20.0 \mathrm{mmol})$ according to GP 1 $\left(60{ }^{\circ} \mathrm{C}, 25 \mathrm{~d}\right)$ gave the cycloadduct $47 \mathrm{a}(5.0 \mathrm{~g}, 95 \%)$ as a colorless solid, m.p. $70{ }^{\circ} \mathrm{C}$. - IR (KBr): $\tilde{v}=3067 \mathrm{~cm}^{-1}, 2998,2845,1653,1636$, 1456, 1437. - ${ }^{1} \mathrm{H}$ NMR (250 MHz, $\left.\mathrm{CDCl}_{3}\right): \delta=0.12-0.35$ (m, $\left.2 \mathrm{H}, \mathrm{CH}_{2}, \mathrm{cPr}-\mathrm{H}\right), 0.34-0.53$ (m, $\left.4 \mathrm{H}, \mathrm{CH}_{2}, \mathrm{cPr}-\mathrm{H}\right), 0.85-0.98$ (m, $\left.2 \mathrm{H}, \mathrm{CH}_{2}, \mathrm{cPr}-\mathrm{H}\right), 4.14$ (s, $\left.1 \mathrm{H}, \mathrm{CH}\right), 4.08$ (m, $2 \mathrm{H}, \mathrm{CH}_{2}$ ), 7.20-7.40 (m, $10 \mathrm{H}, \mathrm{Ar}-\mathrm{H}) .-{ }^{13} \mathrm{C} \mathrm{NMR}\left(62.9 \mathrm{MHz}, \mathrm{CDCl}_{3}\right.$, additional DEPT): $\delta=6.7(-$, $\left.\mathrm{CH}_{2}, \mathrm{cPr}-\mathrm{C}\right), 7.3$ (-, $\left.\mathrm{CH}_{2}, \mathrm{cPr}-\mathrm{C}\right), 7.7$ (-, $\left.\mathrm{CH}_{2}, \mathrm{cPr}-\mathrm{C}\right), 8.6$ (-, $\left.\mathrm{CH}_{2}, \mathrm{cPr}-\mathrm{C}\right), 33.0$ ( $\left.\mathrm{C}_{\text {quat }}, \mathrm{C}-3\right)$, $61.3\left(-, \mathrm{NCH}_{2}\right), 66.5\left(\mathrm{C}_{\text {quat }}, \mathrm{C}-6\right), 76.3(+, \mathrm{CH}), 126.8$ (+, $\left.\mathrm{CH}, \mathrm{Ar}-\mathrm{C}\right), 127.6(+, \mathrm{CH}, \mathrm{Ar}-\mathrm{C})$, 127.9 (+, $2 \mathrm{CH}, \mathrm{Ar}-\mathrm{C}), 128.1$ (+, $2 \mathrm{CH}, \mathrm{Ar}-\mathrm{C}), 128.5$ (+, $4 \mathrm{CH}, \mathrm{Ar}-\mathrm{C}), 137.7\left(\mathrm{C}_{\text {quat }}, \mathrm{Ar}-\mathrm{C}\right)$, $138.1\left(\mathrm{C}_{\text {quat }}, \mathrm{Ar}-\mathrm{C}\right) .-\mathrm{MS}(\mathrm{EI}): m / z(\%)=291(10)\left[\mathrm{M}^{+}\right], 262$ (5), 235 (5), 129 (30), 115 (18), 91 (100). $-\mathrm{C}_{20} \mathrm{H}_{21} \mathrm{NO}$ (291.4): calcd C 82.44, H 7.27, N 4.81; found C 82.19, H 6.97, N 4.76.

Methyl 8-Benzyl-8-aza-7-oxadispiro[2.0.2.3]nonane-9-carboxylate (47b): Column chro-

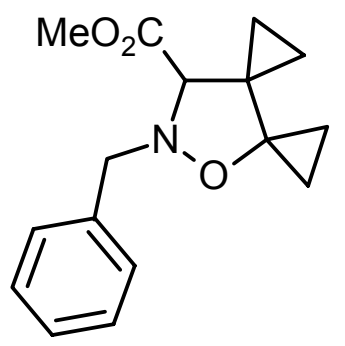
matography $\left(R_{\mathrm{f}}=0.14,115 \mathrm{~g}\right.$ of silica gel, $4.5 \times 15 \mathrm{~cm}$ column, hexane $\left./ \mathrm{Et}_{2} \mathrm{O} 5: 1\right)$ of the residue obtained from nitrone $44 \mathrm{~b}(1.0 \mathrm{~g}$, $5.18 \mathrm{mmol})$ and bicyclopropylidene $24(832 \mathrm{mg}, 0.97 \mathrm{~mL}, 10.4 \mathrm{mmol})$ according to GP $1\left(45^{\circ} \mathrm{C}, 2 \mathrm{~d}\right)$ gave the cycloadduct $47 \mathrm{~b}(1.40 \mathrm{~g}, 100 \%)$ as a yellow oil. - IR (film): $\tilde{v}=3064 \mathrm{~cm}^{-1}, 3031,3006,2953,1766$,

1456, 1437. - ${ }^{1} \mathrm{H}$ NMR (250 MHz, $\left.\mathrm{CDCl}_{3}\right): \delta=0.27-0.36\left(\mathrm{~m}, 2 \mathrm{H}, \mathrm{CH}_{2}, \mathrm{cPr}-\mathrm{H}\right), 0.40-0.46$ (m, $\left.1 \mathrm{H}, \mathrm{CH}_{2}, \mathrm{cPr}-\mathrm{H}\right), 0.61-0.78$ (m, $3 \mathrm{H}, \mathrm{CH}_{2}$, cPr-H), 0.91-0.94 (m, $\left.2 \mathrm{H}, \mathrm{CH}_{2}, \mathrm{cPr}-\mathrm{H}\right), 3.65$ $\left(\mathrm{s}, 3 \mathrm{H}, \mathrm{OCH}_{3}\right), 3.68(\mathrm{~s}, 1 \mathrm{H}, \mathrm{CH}), 4.14\left(\mathrm{~d},{ }^{2} J_{\mathrm{H}, \mathrm{H}}=12.5 \mathrm{~Hz}, 1 \mathrm{H}, \mathrm{NCH}_{2}\right), 4.37\left(\mathrm{~d},{ }^{2} J_{\mathrm{H}, \mathrm{H}}=12.5\right.$ $\left.\mathrm{Hz}, 1 \mathrm{H}, \mathrm{NCH}_{2}\right), 7.23-7.41(\mathrm{~m}, 5 \mathrm{H}, \mathrm{Ar}-\mathrm{H}) .-{ }^{13} \mathrm{C} \mathrm{NMR}\left(62.9 \mathrm{MHz}, \mathrm{CDCl}_{3}\right.$, additional DEPT): $\delta=5.5\left(-, \mathrm{CH}_{2}, \mathrm{cPr}-\mathrm{C}\right), 6.8$ (-, $\left.\mathrm{CH}_{2}, \mathrm{cPr}-\mathrm{C}\right), 8.6\left(-, \mathrm{CH}_{2}, \mathrm{cPr}-\mathrm{C}\right), 10.7$ (-, $\mathrm{CH}_{2}, \mathrm{cPr}-$ C), $30.0\left(\mathrm{C}_{\text {quat }}, \mathrm{C}-3\right), 52.1\left(+, \mathrm{CH}_{3}\right), 62.8\left(-, \mathrm{NCH}_{2}\right), 66.4\left(\mathrm{C}_{\text {quat }}, \mathrm{C}-6\right), 72.7(+, \mathrm{CH}), 127.7(+$, $\mathrm{CH}, \mathrm{Ar}-\mathrm{H}), 128.4(+, 2 \mathrm{CH}, \mathrm{Ar}-\mathrm{H}), 129.4$ (+, $2 \mathrm{CH}, \mathrm{Ar}-\mathrm{H}), 136.0\left(\mathrm{C}_{\text {quat }}, \mathrm{Ar}-\mathrm{C}\right), 170.6\left(\mathrm{C}_{\text {quat }}\right.$, $\mathrm{C}=\mathrm{O}) . \quad-\mathrm{MS}(\mathrm{EI}): m / z(\%)=273(10)\left[\mathrm{M}^{+}\right], 214(90), 105$ (19), 91 (100). - $\mathrm{C}_{16} \mathrm{H}_{19} \mathrm{NO}_{3}$ (273.3): calcd. C 70.31, H 7.01, N 5.12; found C 70.10, H 6.80, N 5.01. 
8-Benzyl-9-cyano-8-aza-7-oxadispiro[2.0.2.3]nonane (47c): Column chromatography

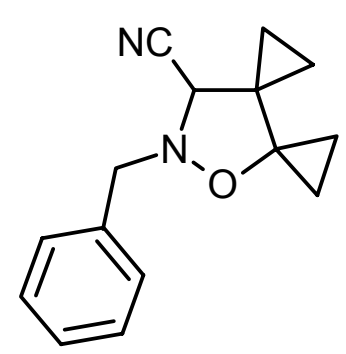

$\left(R_{\mathrm{f}}=0.20,54 \mathrm{~g}\right.$ of silica gel, $4 \times 10 \mathrm{~cm}$ column, hexane $\left./ \mathrm{Et}_{2} \mathrm{O} 2: 1\right)$ of the residue obtained from the nitrone $44 \mathrm{c}(1.46 \mathrm{~g}, 9.12 \mathrm{mmol})$ and bicyclopropylidene $24(1.60 \mathrm{~g}, 1.9 \mathrm{~mL}, 20 \mathrm{mmol})$ according to GP 1 $\left(20^{\circ} \mathrm{C}, 8 \mathrm{~d}\right)$ gave the cycloadduct $47 \mathrm{c}(2.07 \mathrm{~g}, 94 \%)$ as a colorless oil. IR (film): $\tilde{v}=3066 \mathrm{~cm}^{-1}, 3031,2959,2863,2246,1497,1454$. -

${ }^{1} \mathrm{H}$ NMR (300 MHz, $\left.\mathrm{CDCl}_{3}\right): \delta=0.30-0.49\left(\mathrm{~m}, 2 \mathrm{H}, \mathrm{CH}_{2}, \mathrm{cPr}-\mathrm{H}\right), 0.51-0.60\left(\mathrm{~m}, 2 \mathrm{H}, \mathrm{CH}_{2}\right.$, cPr-H), 0.80-0.97 (m, 4 H, $\mathrm{CH}_{2}$, cPr-H), 3.78 (s, $\left.1 \mathrm{H}, \mathrm{CH}\right), 4.11-4.26$ (m, $2 \mathrm{H}, \mathrm{NCH}_{2}$ ), 7.207.37 (m, $5 \mathrm{H}, \mathrm{Ar}-\mathrm{H}) .-{ }^{13} \mathrm{C} \mathrm{NMR}\left(50.3 \mathrm{MHz}, \mathrm{CDCl}_{3}\right.$, additional APT): $\delta=7.3\left(-, \mathrm{CH}_{2}\right.$, cPrC), 7.7 (-, $\left.\mathrm{CH}_{2}, \mathrm{cPr}-\mathrm{C}\right), 8.2$ (-, $\left.\mathrm{CH}_{2}, \mathrm{cPr}-\mathrm{C}\right), 11.2\left(-, \mathrm{CH}_{2}, \mathrm{cPr}-\mathrm{C}\right), 62.5(+, \mathrm{CH}), 66.6\left(\mathrm{C}_{\text {quat }}\right.$, C-6), 128.0 (+, CH, Ar-C), 128.6 (+, 2 CH, Ar-C), 129.2 (+, 2 CH, Ar-C), 135.0 (C $\left.\mathrm{C}_{\text {quat }}, \mathrm{Ar}-\mathrm{C}\right)$, three carbon atoms were not detectable at this temp. $-{ }^{13} \mathrm{C} \mathrm{NMR}\left(75.5 \mathrm{MHz}, \mathrm{C}_{2} \mathrm{D}_{2} \mathrm{Cl}_{4}\right.$, $\left.100{ }^{\circ} \mathrm{C}\right): \delta=7.0\left(-, \mathrm{CH}_{2}, \mathrm{cPr}-\mathrm{C}\right), 7.4\left(-, \mathrm{CH}_{2}, \mathrm{cPr}-\mathrm{C}\right), 7.7\left(-, \mathrm{CH}_{2}, \mathrm{cPr}-\mathrm{C}\right), 10.5\left(-, \mathrm{CH}_{2}, \mathrm{cPr}-\right.$ C), $30.6\left(\mathrm{C}_{\text {quat }}, \mathrm{C}-3\right), 60.8\left(-, \mathrm{NCH}_{2}\right), 62.5(+, \mathrm{CH}), 66.2\left(\mathrm{C}_{\text {quat }}, \mathrm{C}-6\right), 116.1\left(\mathrm{C}_{\text {quat }}, \mathrm{CN}\right), 127.6$ (+, CH, Ar-C), 128.3 (+, 2 CH, Ar-C), 128.8 (+, 2 CH, Ar-C), 135.3 ( $\left.\mathrm{C}_{\text {quat }}, \mathrm{Ar}-\mathrm{C}\right) .-\mathrm{MS}(\mathrm{EI})$ : $m / z(\%)=239(20)\left[\mathrm{M}^{+}-\mathrm{H}\right], 214$ (10), 211 (20), 105 (50), 91 (100). - MS (DCI): $m / z(\%)=481(5)\left[2 \mathrm{M}+\mathrm{H}^{+}\right], 258(8)\left[\mathrm{M}+\mathrm{NH}_{4}^{+}\right], 241(100)\left[\mathrm{M}+\mathrm{H}^{+}\right] .-\mathrm{C}_{15} \mathrm{H}_{16} \mathrm{~N}_{2} \mathrm{O}$ (240.3): calcd. C 74.97, H 6.71, N 11.66; found C 74.76, H 6.65, N 11.63;

9-Cyano-8-(4-methoxybenzyl)-8-aza-7-oxadispiro[2.0.2.3]nonane (47d): Column chro-

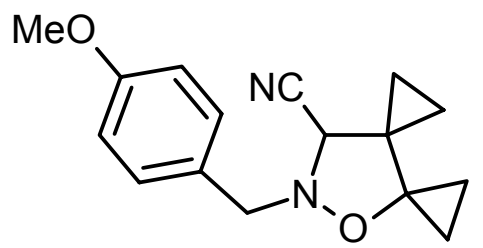
matography $\left(R_{\mathrm{f}}=0.34,55 \mathrm{~g}\right.$ of silica gel, $3 \times 17 \mathrm{~cm}$ column, hexane/ $\left.\mathrm{Et}_{2} \mathrm{O} 10: 1\right)$ of the residue obtained from the nitrone 44d $(2.5 \mathrm{~g}, 13 \mathrm{mmol})$ and bicyclopropylidene $\mathbf{2 4}(2.10 \mathrm{~g}$, $2.46 \mathrm{~mL}, 26.2 \mathrm{mmol})$ according to $\mathrm{GP} 1\left(20^{\circ} \mathrm{C}, 8 \mathrm{~d}\right)$ gave the cycloadduct $47 \mathbf{d}(3.50 \mathrm{~g}, 100 \%)$ as a colorless solid, m.p. $70-71{ }^{\circ} \mathrm{C}$. $-\mathrm{IR}(\mathrm{KBr}): \tilde{v}=3075$ $\mathrm{cm}^{-1}, 3010,2934,2868,2838,2246,1611,1585,1512,1468 .-{ }^{1} \mathrm{H}$ NMR (250 MHz, $\left.\mathrm{CDCl}_{3}\right)$ : $\delta=0.36-0.70\left(\mathrm{~m}, 4 \mathrm{H}, \mathrm{CH}_{2}, \mathrm{cPr}-\mathrm{H}\right), 0.82-1.04\left(\mathrm{~m}, 4 \mathrm{H}, \mathrm{CH}_{2}, \mathrm{cPr}-\mathrm{H}\right), 3.80\left(\mathrm{~s}, 3 \mathrm{H}, \mathrm{OCH}_{3}\right)$, 3.81 (s, $1 \mathrm{H}, \mathrm{CH}), 4.04-4.28$ (m, 2 H, NCH$), 6.85-6.91$ (m, $2 \mathrm{H}, \mathrm{Ar}-\mathrm{H}), 7.30-7.37$ (m, $2 \mathrm{H}$, Ar-H). $-{ }^{13} \mathrm{C}$ NMR (50.3 MHz, $\mathrm{CDCl}_{3}$, additional APT): $\delta=7.2\left(-, \mathrm{CH}_{2}, \mathrm{cPr}-\mathrm{C}\right), 7.7\left(-, \mathrm{CH}_{2}\right.$, cPr-C), $8.2\left(-, \mathrm{CH}_{2}, \mathrm{cPr}-\mathrm{C}\right), 11.2\left(-, \mathrm{CH}_{2}, \mathrm{cPr}-\mathrm{C}\right), 55.2\left(+, \mathrm{OCH}_{3}\right), 62.3(+, \mathrm{CH}), 66.5\left(\mathrm{C}_{\text {quat }}\right.$, C-6), 114.0 (+, 2 CH, Ar-C), 126.9 ( $\left.\mathrm{C}_{\text {quat }}, \mathrm{Ar}-\mathrm{C}\right), 130.5$ (+, $\left.2 \mathrm{CH}, \mathrm{Ar}-\mathrm{C}\right), 159.4$ ( $\mathrm{C}_{\text {quat, }}$ Ar-C), three carbon atoms were not detectable at this temp. $-{ }^{13} \mathrm{C} \mathrm{NMR}\left(75.5 \mathrm{MHz}, \mathrm{C}_{2} \mathrm{D}_{2} \mathrm{Cl}_{4}\right.$, $\left.100{ }^{\circ} \mathrm{C}\right): \delta=6.9\left(-, \mathrm{CH}_{2}, \mathrm{cPr}-\mathrm{C}\right), 7.4\left(-, \mathrm{CH}_{2}, \mathrm{cPr}-\mathrm{C}\right), 7.7\left(-, \mathrm{CH}_{2}, \mathrm{cPr}-\mathrm{C}\right), 10.5$ (-, $\mathrm{CH}_{2}, \mathrm{cPr}-$ 
C), $30.5\left(\mathrm{C}_{\text {quat }}, \mathrm{C}-3\right), 55.2\left(+, \mathrm{OCH}_{3}\right), 60.2\left(-, \mathrm{NCH}_{2}\right), 62.3(+, \mathrm{CH}), 66.2\left(\mathrm{C}_{\text {quat }}, \mathrm{C}-6\right), 114.1$ $(+, 2 \mathrm{CH}, \mathrm{Ar}-\mathrm{C}), 116.2\left(\mathrm{C}_{\text {quat }}, \mathrm{CN}\right), 127.3$ ( $\left.\mathrm{C}_{\text {quat }}, \mathrm{Ar}-\mathrm{C}\right), 130.1(+, 2 \mathrm{CH}, \mathrm{Ar}-\mathrm{C}), 159.4\left(\mathrm{C}_{\text {quat }}\right.$, Ar-C). - MS (EI): $m / z(\%)=270(20)\left[\mathrm{M}^{+}\right], 241$ (8), 135 (25), 121 (100). $-\mathrm{C}_{16} \mathrm{H}_{18} \mathrm{~N}_{2} \mathrm{O}_{2}$ (270.3): calcd. C 71.09, H 6.71, N 10.36; found C 70.97, H 6.58, N 10.12.

8-Benzyl-9-(2-iodophenyl)-7-oxa-8-azadispiro[2.0.2.3]nonane (47e): Column chromato-

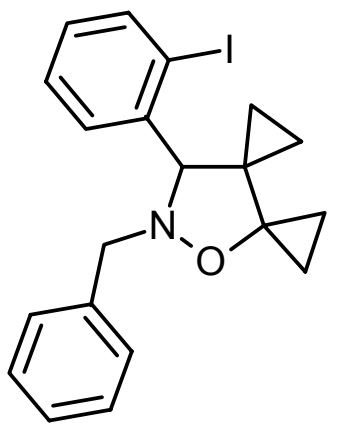
graphy $\left(R_{\mathrm{f}}=0.37,50 \mathrm{~g}\right.$ of silica gel, $3 \times 14 \mathrm{~cm}$ column, hexane $/ \mathrm{Et}_{2} \mathrm{O}$ $5: 1)$ of the residue obtained from nitrone $44 \mathrm{e}(0.920 \mathrm{~g}, 2.73 \mathrm{mmol})$ and bicyclopropylidene $24(0.219 \mathrm{~g}, 0.26 \mathrm{~mL}, 2.73 \mathrm{mmol})$ according to GP $1\left(60{ }^{\circ} \mathrm{C}, 6 \mathrm{~d}\right)$ gave the cycloadduct $47 \mathrm{e}(1.00 \mathrm{~g}, 88 \%)$ as a yellow oil. - IR (film): $\tilde{v}=3053 \mathrm{~cm}^{-1}, 3031,2998,2871,2831,1497,1456$, 1425. - ${ }^{1} \mathrm{H}$ NMR $\left(250 \mathrm{MHz}, \mathrm{CDCl}_{3}\right): \delta=0.10-0.22\left(\mathrm{~m}, 2 \mathrm{H}, \mathrm{CH}_{2}, \mathrm{cPr}-\right.$ H), 0.36-0.45 (m, $\left.2 \mathrm{H}, \mathrm{CH}_{2}, \mathrm{cPr}-\mathrm{H}\right), 0.55-0.57$ (m, 1H, $\left.\mathrm{CH}_{2}, \mathrm{cPr}-\mathrm{H}\right), 0.89-0.99$ (m, $3 \mathrm{H}, \mathrm{CH}_{2}$, cPr-H), 4.07-4.13 (d, $\left.{ }^{2} J_{\mathrm{H}, \mathrm{H}}=15.0 \mathrm{~Hz}, 1 \mathrm{H}, \mathrm{NCH}_{2}\right), 4.22-4.28\left(\mathrm{~d},{ }^{2} J_{\mathrm{H}, \mathrm{H}}=15.0 \mathrm{~Hz}, 1 \mathrm{H}\right.$, $\left.\mathrm{NCH}_{2}\right), 4.64(\mathrm{~s}, 1 \mathrm{H}), 6.92-6.96\left(\mathrm{td},{ }^{3} J_{\mathrm{H}, \mathrm{H}}=7.5,{ }^{4} J_{\mathrm{H}, \mathrm{H}}=2.5 \mathrm{~Hz}, 1 \mathrm{H}, \mathrm{Ar}-\mathrm{H}\right), 7.19-7.36(\mathrm{~m}, 6$ $\mathrm{H}, \mathrm{Ar}-\mathrm{H}), 7.71-7.74\left(\mathrm{dd},{ }^{3} J_{\mathrm{H}, \mathrm{H}}=7.5,{ }^{4} J_{\mathrm{H}, \mathrm{H}}=1.2 \mathrm{~Hz}, 1 \mathrm{H}, \mathrm{Ar}-\mathrm{H}\right), 7.80-7.84\left(\mathrm{dd},{ }^{3} J_{\mathrm{H}, \mathrm{H}}=7.5\right.$, $\left.{ }^{4} J_{\mathrm{H}, \mathrm{H}}=2.5 \mathrm{~Hz}, 1 \mathrm{H}, \mathrm{Ar}-\mathrm{H}\right) .-{ }^{13} \mathrm{C} \mathrm{NMR}\left(62.9 \mathrm{MHz}, \mathrm{CDCl}_{3}\right.$, additional APT): $\delta=6.5\left(-, \mathrm{CH}_{2}\right.$, cPr-C), 7.1 (-, $\left.\mathrm{CH}_{2}, \mathrm{cPr}-\mathrm{C}\right), 8.9$ (-, $\left.\mathrm{CH}_{2}, \mathrm{cPr}-\mathrm{C}\right), 9.3$ (-, $\left.\mathrm{CH}_{2}, \mathrm{cPr}-\mathrm{C}\right), 33.5$ (-, $\left.\mathrm{C}_{\text {quat }}, \mathrm{C}-3\right), 61.8$ (-, $\left.\mathrm{NCH}_{2}\right), 66.9$ (-, $\left.\mathrm{C}_{\text {quat }}, \mathrm{C}-6\right), 78.5$ (+, CH), 100.1 (-, $\left.\mathrm{C}_{\text {quat }}, \mathrm{Ar}-\mathrm{C}\right), 127.0$ (+, $\left.\mathrm{CH}, \mathrm{Ar}-\mathrm{C}\right)$, $128.1(+, 2 \mathrm{CH}, \mathrm{Ar}-\mathrm{C}), 128.3$ (+, $\mathrm{CH}, \mathrm{Ar}-\mathrm{C}), 128.8$ (+, $2 \mathrm{CH}, \mathrm{Ar}-\mathrm{C}), 129.2(+, \mathrm{CH}, \mathrm{Ar}-\mathrm{C})$, 131.1 (+, CH, Ar-C), 137.5 (-, $\left.\mathrm{C}_{\text {quat }}, \mathrm{Ar}-\mathrm{C}\right), 138.8$ (+, CH, Ar-C), 141.5(-, $\left.\mathrm{C}_{\text {quat }}, \mathrm{Ar}-\mathrm{C}\right) .-$ MS (EI): $m / z(\%)=417$ (20), 348 (5), 307 (5), 214 (15), 129 (60), 106 (10), 91 (100), 65 (15). $-\mathrm{C}_{20} \mathrm{H}_{20} \mathrm{INO}$ (417.28): calcd; C 57.57, H 4.8, N 3.36; found C 57.65, H 4.66, N 3.28.

8-(p-Methoxybenzyl)-9-(2-iodophenyl)-7-oxa-8-azadispiro[2.0.2.3]nonane (47f): Column

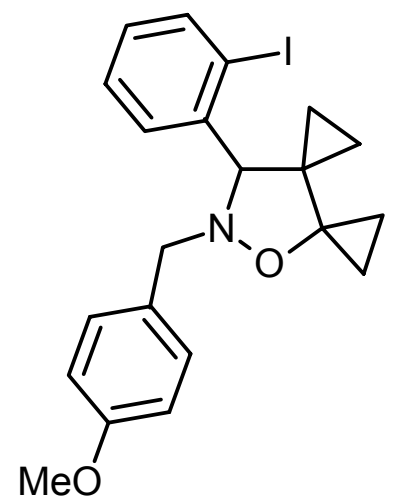
chromatography $\left(R_{\mathrm{f}}=0.4,38 \mathrm{~g}\right.$ of silica gel, $6 \times 4 \mathrm{~cm}$ column, hexane/ $\left.\mathrm{Et}_{2} \mathrm{O} 4: 1\right)$ of the residue obtained from nitrone $44 \mathrm{f}(0.906 \mathrm{~g}$, $2.46 \mathrm{mmol})$ and bicyclopropylidene $24(0.197 \mathrm{~g}, \quad 0.230 \mathrm{~mL}$, $2.46 \mathrm{mmol})$ according to GP $1\left(65^{\circ} \mathrm{C}, 4 \mathrm{~d}\right)$ gave the cycloadduct 47f $(0.827 \mathrm{~g}, 75 \%)$ as a yellow solid, m.p $=84-85^{\circ} \mathrm{C}$. - IR (film): $\tilde{v}=3066 \mathrm{~cm}^{-1}, 2996,2837,1616,1513,1245,1030,1008$. ${ }^{1} \mathrm{H}$ NMR (250 MHz, $\left.\mathrm{CDCl}_{3}\right): \delta=0.13-0.22\left(\mathrm{~m}, 2 \mathrm{H}, \mathrm{CH}_{2}, \mathrm{cPr}-\mathrm{H}\right)$, 0.36-0.56 (m, $3 \mathrm{H}, \mathrm{CH}_{2}$, cPr-H), 0.88-1.00 (m, 3 H, $\mathrm{CH}_{2}$, cPr-H), 3.76 (s, $3 \mathrm{H}, \mathrm{OCH}_{3}$ ), 4.02- 
$4.07\left(\mathrm{~d},{ }^{2} J_{\mathrm{H}, \mathrm{H}}=14.0 \mathrm{~Hz}, 1 \mathrm{H}, \mathrm{NCH}_{2}\right), 4.17-4.22\left(\mathrm{~d},{ }^{2} J_{\mathrm{H}, \mathrm{H}}=14.0 \mathrm{~Hz}, 1 \mathrm{H}, \mathrm{NCH}_{2}\right), 4.78(\mathrm{~s}, 1$ $\mathrm{H}), 6.76-6.82(\mathrm{~m}, 2 \mathrm{H}, \mathrm{Ar}-\mathrm{H}), 6.89-6.95\left(\mathrm{td},{ }^{3} J_{\mathrm{H}, \mathrm{H}}=7.7,{ }^{4} J_{\mathrm{H}, \mathrm{H}}=1.6 \mathrm{~Hz}, 1 \mathrm{H}, \mathrm{Ar}-\mathrm{H}\right), 7.24$ $7.37(\mathrm{~m}, 3 \mathrm{H}, \mathrm{Ar}-\mathrm{H}), 7.70-7.74\left(\mathrm{dd},{ }^{3} J_{\mathrm{H}, \mathrm{H}}=8.0,{ }^{4} J_{\mathrm{H}, \mathrm{H}}=1.0 \mathrm{~Hz}, 1 \mathrm{H}, \mathrm{Ar}-\mathrm{H}\right), 7.78-7.82(\mathrm{dd}$, $\left.{ }^{3} J_{\mathrm{H}, \mathrm{H}}=8.0,{ }^{4} J_{\mathrm{H}, \mathrm{H}}=1.6 \mathrm{~Hz}, 1 \mathrm{H}, \mathrm{Ar}-\mathrm{H}\right) .-{ }^{13} \mathrm{C} \mathrm{NMR}\left(62.9 \mathrm{MHz}, \mathrm{CDCl}_{3}\right.$, additional APT): $\delta=$ 6.5 (-, $\left.\mathrm{CH}_{2}, \mathrm{cPr}-\mathrm{C}\right), 7.1$ (-, $\left.\mathrm{CH}_{2}, \mathrm{cPr}-\mathrm{C}\right), 8.8$ (-, $\left.\mathrm{CH}_{2}, \mathrm{cPr}-\mathrm{C}\right), 9.4$ (-, $\left.\mathrm{CH}_{2}, \mathrm{cPr}-\mathrm{C}\right), 33.5$ (-, $\left.\mathrm{C}_{\text {quat, }} \mathrm{C}-3\right), 55.2\left(+, \mathrm{OCH}_{3}\right), 61.3\left(-, \mathrm{NCH}_{2}\right), 66.9\left(-, \mathrm{C}_{\text {quat }}, \mathrm{C}-6\right), 78.2(+, \mathrm{CH}), 100.1\left(-, \mathrm{C}_{\text {quat }}\right.$, Ar-C), 113.5 (+, 2 CH, Ar-C), 128.3 (+, CH, Ar-C), 129.1 (+, CH, Ar-C), 129.5 (-, C quat, ArC), $130.1(+, 2 \mathrm{CH}, \mathrm{Ar}-\mathrm{C}), 131.0(+, \mathrm{CH}, \mathrm{Ar}-\mathrm{C}), 138.8$ (+, $\mathrm{CH}, \mathrm{Ar}-\mathrm{C}), 141.7$ (-, $\left.\mathrm{C}_{\text {quat }}, \mathrm{Ar}-\mathrm{C}\right)$, 158.7 (-, $\left.\mathrm{C}_{\text {quat }}, \mathrm{Ar}-\mathrm{C}\right) .-\mathrm{MS}(\mathrm{EI}): m / z(\%)=447(8)\left[\mathrm{M}^{+}\right], 337$ (8), 244 (10), 162 (6), 135 (24), 121 (100), 91 (10), 77 (16). - $\mathrm{C}_{21} \mathrm{H}_{22} \mathrm{INO}_{2}$ (447.31): calcd; C 56.39, H 4.96, N 3.13; found $\mathrm{C}, \mathrm{H}, \mathrm{N}$.

8-(p-Methoxybenzyl)-7-oxa-8-aza-dispiro[2.0.2.3]nonane (47g): Column chromatography

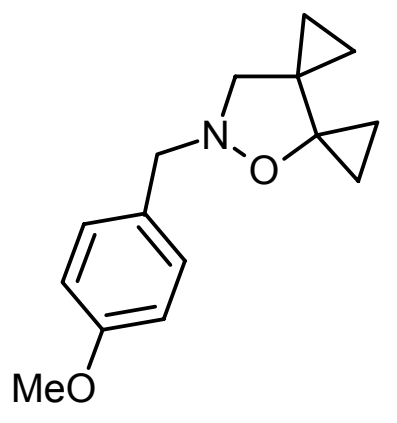

$\left(R_{\mathrm{f}}=0.27,42 \mathrm{~g}\right.$ of silica gel, $3 \times 12 \mathrm{~cm}$ column, hexane $\left./ \mathrm{Et}_{2} \mathrm{O} 2: 1\right)$ of the residue obtained from the nitrone $44 \mathrm{~g}(0.176 \mathrm{~g}, 1.06 \mathrm{mmol})$ and bicyclopropylidene $24(0.424 \mathrm{~g}, 0.50 \mathrm{~mL}, 5.3 \mathrm{mmol})$ according to GP 1 in $\mathrm{CH}_{2} \mathrm{Cl}_{2}\left(20{ }^{\circ} \mathrm{C}, 6 \mathrm{~d}\right)$ gave the cycloadduct $47 \mathrm{~g}(0.055 \mathrm{~g}$, $21 \%$ ) as a colorless oil. - IR (film): $\tilde{v}=3072 \mathrm{~cm}^{-1}, 3000,2934$, 2835, 1612, 1586, 1513, 1463, 1442. - ${ }^{1} \mathrm{H}$ NMR (250 MHz, $\left.\mathrm{CDCl}_{3}\right)$ : $\delta=0.29$ (bs, $\left.4 \mathrm{H}, \mathrm{CH}_{2}, \mathrm{cPr}-\mathrm{H}\right), 0.56$ (bs, $\left.2 \mathrm{H}, \mathrm{CH}_{2}, \mathrm{cPr}-\mathrm{H}\right), 0.78$ (bs, $\left.2 \mathrm{H}, \mathrm{CH}_{2}, \mathrm{cPr}-\mathrm{H}\right), 2.90$ (bs, $1 \mathrm{H}, \mathrm{NCH}_{2}$ ), 3.3 (bs, $1 \mathrm{H}, \mathrm{NCH}_{2}$ ), 3.7 (s, $3 \mathrm{H}, \mathrm{OCH}_{3}$ ), 3.88 (bs, $1 \mathrm{H}, \mathrm{NCH}_{2} \mathrm{Ph}$ ), 4.15 (bs, 1 $\mathrm{H}, \mathrm{NCH}_{2} \mathrm{Ph}$ ), 6.74-6.79 (m, $\left.2 \mathrm{H}, \mathrm{Ar}-\mathrm{H}\right), 7.19-7.22$ (m, $\left.2 \mathrm{H}, \mathrm{Ar}-\mathrm{H}\right) .-{ }^{1} \mathrm{H}$ NMR (300 MHz, $\left.\mathrm{C}_{2} \mathrm{D}_{2} \mathrm{Cl}_{4}, 10{ }^{\circ} \mathrm{C}\right): \delta=0.35-0.40\left(\mathrm{~m}, 2 \mathrm{H}, \mathrm{CH}_{2}, \mathrm{cPr}-\mathrm{H}\right), 0.43-0.47\left(\mathrm{~m}, 2 \mathrm{H}, \mathrm{CH}_{2}, \mathrm{cPr}-\mathrm{H}\right) 0.66-$ 0.70 (m, $\left.2 \mathrm{H}, \mathrm{CH}_{2}, \mathrm{cPr}-\mathrm{H}\right), 0.84-0.89$ (m, $\left.2 \mathrm{H}, \mathrm{CH}_{2}, \mathrm{cPr}-\mathrm{H}\right), 3.22$ (s, $\left.2 \mathrm{H}, \mathrm{NCH}_{2}\right), 3.82$ (s, $3 \mathrm{H}$, $\left.\mathrm{OCH}_{3}\right), 4.12$ (s, $\left.2 \mathrm{H}, \mathrm{NCH}_{2} \mathrm{Ph}\right), 6.86-6.91$ (m, $\left.2 \mathrm{H}, \mathrm{Ar}-\mathrm{H}\right), 7.28-7.32$ (m, $\left.2 \mathrm{H}, \mathrm{Ar}-\mathrm{H}\right)$. ${ }^{13} \mathrm{C}$ NMR $\left(75.5 \mathrm{MHz}, \mathrm{C}_{2} \mathrm{D}_{2} \mathrm{Cl}_{4}, 100{ }^{\circ} \mathrm{C}\right): \delta=7.3\left(2 \mathrm{CH}_{2}, \mathrm{cPr}-\mathrm{C}\right), 8.1\left(2 \mathrm{CH}_{2}, \mathrm{cPr}-\mathrm{C}\right), 26.4$ $\left(\mathrm{C}_{\text {quat }}, \mathrm{C}-3\right), 55.1\left(\mathrm{OCH}_{3}\right), 62.2\left(\mathrm{CH}_{2}, *\right), 62.9\left(\mathrm{CH}_{2}, *\right), 65.6\left(\mathrm{C}_{\text {quat }}, \mathrm{C}-6\right), 113.7(2 \mathrm{CH}, \mathrm{Ar}-\mathrm{C})$, 129.7 ( $\left.\mathrm{C}_{\text {quat }}, \mathrm{Ar}-\mathrm{C}\right), 130.0$ (2 CH, Ar-C), 158.8 (C $\left.\mathrm{C}_{\text {quat }}, \mathrm{Ar}-\mathrm{C}\right) .-\mathrm{MS}(\mathrm{EI}): m / z(\%)=245(85)$, 230 (22), 216 (25), 188 (15), 135 (45), 121 (100). - $\mathrm{C}_{15} \mathrm{H}_{19} \mathrm{NO}_{2}$ (245.32): calcd. C 73.44, H 7.81, N 5.71; found C 73.22, H 8.06, N 5.61. 


\section{Preparation of $\beta$-Lactams 53a-e. General Procedure 2.}

(GP 2): To the solution of the respective isoxazolidine 47 in acetonitrile was added trifluoroacetic acid (TFA), and the resulting mixture was stirred at $70{ }^{\circ} \mathrm{C}$ for the indicated time. After cooling to ambient temp., the mixture was filtered through a pad of Celite, concentrated under reduced pressure, and the crude product was purified by column chromatography on silica gel.

5-Benzyl-6-phenyl-5-azaspiro[2.3] hexane-4-one (53a): Column chromatography $\left(R_{\mathrm{f}}=0.15\right.$,

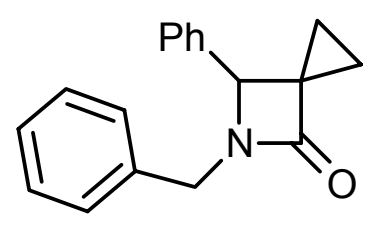
$40 \mathrm{~g}$ of silica gel, $3 \times 14 \mathrm{~cm}$ column, hexane/ $\left.\mathrm{Et}_{2} \mathrm{O} 3: 1\right)$ of the residue obtained from the isoxazolidine $47 \mathbf{a}(1.48 \mathrm{~g}, 5.08 \mathrm{mmol})$ and TFA $(698 \mathrm{mg}, 0.472 \mathrm{~mL}, 6.12 \mathrm{mmol})$ in acetonitrile $(32 \mathrm{~mL})$ according to GP $2(3 \mathrm{~h})$ gave the $\beta$-lactam 53a $(1.0 \mathrm{~g}, 75 \%)$ as a colorless solid, m.p. $\quad 64-65^{\circ} \mathrm{C} . \quad-\operatorname{IR}(\mathrm{KBr}): \tilde{v}=3029 \mathrm{~cm}^{-1}, 1745, \quad 1653,1559,1494,1456 . \quad-{ }^{1} \mathrm{H}$ $\operatorname{NMR}\left(250 \mathrm{MHz}, \mathrm{CDCl}_{3}\right): \delta=0.37-0.43\left(\mathrm{ddd},{ }^{2} J_{\mathrm{H}, \mathrm{H}}=10.0,{ }^{3} J_{\mathrm{H}, \mathrm{H}}=7.5,5.0 \mathrm{~Hz}, 1 \mathrm{H}, \mathrm{CH}_{2}\right.$, cPr-H), 1.01-1.06 (ddd, $\left.{ }^{2} J_{\mathrm{H}, \mathrm{H}}=10.0,{ }^{3} J_{\mathrm{H}, \mathrm{H}}=7.5,5.0 \mathrm{~Hz}, 1 \mathrm{H}, \mathrm{CH}_{2}, \mathrm{cPr}-\mathrm{H}\right), 1.09-1.18$ (ddd, $\left.{ }^{2} J_{\mathrm{H}, \mathrm{H}}=10.0,{ }^{3} J_{\mathrm{H}, \mathrm{H}}=7.5,5.0 \mathrm{~Hz}, 1 \mathrm{H}, \mathrm{CH}_{2}, \mathrm{cPr}-\mathrm{H}\right), 1.24-1.32\left(\mathrm{ddd},{ }^{2} J_{\mathrm{H}, \mathrm{H}}=10.0,{ }^{3} J_{\mathrm{H}, \mathrm{H}}=7.5\right.$, $\left.5.0 \mathrm{~Hz}, 1 \mathrm{H}, \mathrm{CH}_{2}, \mathrm{cPr}-\mathrm{H}\right), 3.85\left(\mathrm{~d},{ }^{2} J_{\mathrm{H}, \mathrm{H}}=15.0 \mathrm{~Hz}, 1 \mathrm{H}, \mathrm{NCH}_{2}\right), 4.48(\mathrm{~s}, 1 \mathrm{H}, \mathrm{CH}), 4.88(\mathrm{~d}$, $\left.{ }^{2} J_{\mathrm{H}, \mathrm{H}}=15.0 \mathrm{~Hz}, 1 \mathrm{H}, \mathrm{NCH}_{2}\right), 7.15-7.21(\mathrm{~m}, 4 \mathrm{H}, \mathrm{Ar}-\mathrm{H}), 7.24-7.43(\mathrm{~m}, 6 \mathrm{H}, \mathrm{Ar}-\mathrm{H}) .-{ }^{13} \mathrm{C}$ NMR (62.9 MHz, $\mathrm{CDCl}_{3}$, additional DEPT): $\delta=7.2\left(-, \mathrm{CH}_{2}, \mathrm{cPr}-\mathrm{C}\right), 8.2\left(-, \mathrm{CH}_{2}, \mathrm{cPr}-\mathrm{C}\right)$, $40.3\left(\mathrm{C}_{\text {quat }}, \mathrm{C}-3\right), 44.5\left(-, \mathrm{NCH}_{2}\right), 61.4(+, \mathrm{CH}), 127.5(+, \mathrm{CH}, \mathrm{Ar}-\mathrm{C}), 127.6(+, \mathrm{CH}, \mathrm{Ar}-\mathrm{C})$, 128.4 (+, $4 \mathrm{CH}, \mathrm{Ar}-\mathrm{C}), 128.6$ (+, $2 \mathrm{CH}, \mathrm{Ar}-\mathrm{C}), 128.7$ (+, $2 \mathrm{CH}, \mathrm{Ar}-\mathrm{C}), 135.8\left(\mathrm{C}_{\text {quat }}, \mathrm{Ar}-\mathrm{C}\right)$, $136.3\left(\mathrm{C}_{\text {quat }}, \mathrm{Ar}-\mathrm{C}\right), 172.4\left(\mathrm{C}_{\text {quat }}, \mathrm{C}=\mathrm{O}\right) .-\mathrm{MS}(\mathrm{EI}): m / z(\%)=263(36)\left[\mathrm{M}^{+}\right], 172$ (10), 130 (100), 129 (85), 115 (42), 91 (65). - $\mathrm{C}_{18} \mathrm{H}_{17} \mathrm{NO}$ (263.3): calcd. C 82.10, H 6.51, N 5.32; found C 82.0, H 6.25, N 5.12 .

Methyl 5-Benzyl-6-oxo-5-azaspiro[2.3]hexane-4-carboxylate (53b): Column chromato-

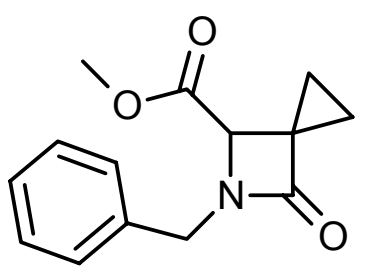
graphy $\left(R_{\mathrm{f}}=0.21,40 \mathrm{~g}\right.$ of silica gel, $3 \times 14 \mathrm{~cm}$ column, hexane $/ \mathrm{Et}_{2} \mathrm{O}$ $1: 1)$ of the residue obtained from the isoxazolidine $47 \mathbf{b}(1.41 \mathrm{~g}$, $5.16 \mathrm{mmol})$ and TFA $(0.710 \mathrm{~g}, 0.480 \mathrm{~mL}, 6.22 \mathrm{mmol})$ in acetonitrile $(32 \mathrm{~mL})$ according to GP $2(12 \mathrm{~h})$ gave the $\beta$-lactam $\mathbf{5 3 b}(990 \mathrm{mg}$, 78\%) as a yellow oil. - IR (film): $\tilde{v}=3065 \mathrm{~cm}^{-1}, 3029,3003,2953,2849,1756,1729,1455$, 1436. $-{ }^{1} \mathrm{H}$ NMR $\left(250 \mathrm{MHz}, \mathrm{CDCl}_{3}\right): \delta=0.84-0.92\left(\mathrm{~m}, 1 \mathrm{H}, \mathrm{CH}_{2}, \mathrm{cPr}-\mathrm{H}\right), 1.06-1.16(\mathrm{~m}, 1 \mathrm{H}$, 
$\left.\mathrm{CH}_{2}, \mathrm{cPr}-\mathrm{H}\right), 1.18-1.29$ (m, $\left.2 \mathrm{H}, \mathrm{CH}_{2}, \mathrm{cPr}-\mathrm{H}\right), 3.71$ (s, $\left.3 \mathrm{H}, \mathrm{OCH}_{3}\right), 4.02$ (s, $\left.1 \mathrm{H}, \mathrm{CH}\right), 4.24$ (d, $\left.{ }^{2} J_{\mathrm{H}, \mathrm{H}}=15.0 \mathrm{~Hz}, 1 \mathrm{H}, \mathrm{NCH}_{2}\right), 4.91\left(\mathrm{~d},{ }^{2} J_{\mathrm{H}, \mathrm{H}}=15.0 \mathrm{~Hz}, 1 \mathrm{H}, \mathrm{NCH}_{2}\right), 7.25-7.39(\mathrm{~m}, 5 \mathrm{H}, \mathrm{Ar}-\mathrm{H})$. $-{ }^{13} \mathrm{C}$ NMR (62.9 MHz, $\mathrm{CDCl}_{3}$, additional DEPT): $\delta=6.5\left(-, \mathrm{CH}_{2}, \mathrm{cPr}-\mathrm{C}\right), 8.0\left(-, \mathrm{CH}_{2}, \mathrm{cPr}-\right.$ C), $37.2\left(\mathrm{C}_{\text {quat }}, \mathrm{C}-3\right), 45.5\left(-, \mathrm{NCH}_{2}\right), 52.1(+, \mathrm{CH}), 57.4\left(+, \mathrm{OCH}_{3}\right), 127.7(+, \mathrm{CH}, \mathrm{Ar}-\mathrm{C})$, $128.3(+, 2 \mathrm{CH}, \mathrm{Ar}-\mathrm{C}), 128.7(+, 2 \mathrm{CH}, \mathrm{Ar}-\mathrm{C}), 135.2\left(\mathrm{C}_{\text {quat }}, \mathrm{Ar}-\mathrm{C}\right), 170.0\left(\mathrm{C}_{\text {quat }}, \mathrm{C}=\mathrm{O}, *\right)$, $170.9\left(\mathrm{C}_{\text {quat }}, \mathrm{C}=\mathrm{O}, *\right) .-\mathrm{MS}(\mathrm{EI}): m / z(\%)=245(4)\left[\mathrm{M}^{+}\right], 217$ (20), 186 (30), 158 (40), 91 (100). $-\mathrm{C}_{14} \mathrm{H}_{15} \mathrm{NO}_{3}$ (245.3): calcd. C 68.56, H 6.16, N 5.71; found C 68.45, H 6.08, 5.49.

5-Benzyl-6-oxo-5-azaspiro[2.3]hexane-4-carbonitrile (53c): Column chromatography

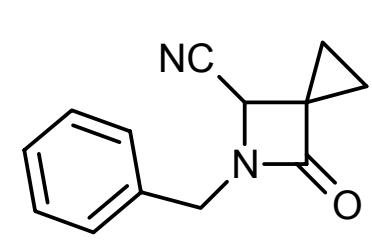

$\left(R_{\mathrm{f}}=0.11,41 \mathrm{~g}\right.$ of silica gel, $3 \times 12 \mathrm{~cm}$ column, hexane $\left./ \mathrm{Et}_{2} \mathrm{O} 2: 1\right)$ of the residue obtained from the isoxazolidine $47 \mathrm{c}(627 \mathrm{mg}, 2.61 \mathrm{mmol})$ and TFA $(357 \mathrm{mg}, 0.24 \mathrm{~mL}, 3.13 \mathrm{mmol})$ in acetonitrile $(15 \mathrm{~mL})$ according to GP $2(12 \mathrm{~h})$ gave the $\beta$-lactam 53c $(415 \mathrm{mg}, 75 \%)$ as a colorless oil. - IR (film): $\tilde{v}=3065 \mathrm{~cm}^{-1}, 3032,3009,2923,2243,1772,1496,1456,1382$, 1355. - ${ }^{1} \mathrm{H}$ NMR (300 MHz, $\left.\mathrm{CDCl}_{3}\right): \delta=1.17-1.29$ (m, $\left.2 \mathrm{H}, \mathrm{CH}_{2}, \mathrm{cPr}-\mathrm{H}\right), 1.32-1.44(\mathrm{~m}, 2 \mathrm{H}$, $\left.\mathrm{CH}_{2}, \mathrm{cPr}-\mathrm{H}\right), 4.14(\mathrm{~s}, 1 \mathrm{H}, \mathrm{CH}), 4.25\left(\mathrm{~d},{ }^{2} J_{\mathrm{H}, \mathrm{H}}=15.1 \mathrm{~Hz}, 1 \mathrm{H}, \mathrm{NCH}_{2}\right), 4.81\left(\mathrm{~d},{ }^{2} J_{\mathrm{H}, \mathrm{H}}=15.1\right.$ $\left.\mathrm{Hz}, 1 \mathrm{H}, \mathrm{NCH}_{2}\right), 7.27-7.42$ (m, $\left.5 \mathrm{H}, \mathrm{Ar}-\mathrm{H}\right) .-{ }^{13} \mathrm{C} \mathrm{NMR}\left(75.5 \mathrm{MHz}, \mathrm{CDCl}_{3}\right.$, additional APT): $\delta=8.2\left(-, \mathrm{CH}_{2}, \mathrm{cPr}-\mathrm{C}\right), 9.1\left(-, \mathrm{CH}_{2}, \mathrm{cPr}-\mathrm{C}\right), 38.3$ (-, $\left.\mathrm{C}_{\text {quat }}, \mathrm{C}-3\right), 46.0\left(-, \mathrm{NCH}_{2}\right), 46.7(+$, $\mathrm{CH}), 115.6\left(-, \mathrm{C}_{\text {quat }}, \mathrm{CN}\right), 128.3(+, \mathrm{CH}), 128.4(+, 2 \mathrm{CH}, \mathrm{Ar}-\mathrm{C}), 129.0(+, 2 \mathrm{CH}, \mathrm{Ar}-\mathrm{C})$, $133.9\left(-, \mathrm{C}_{\text {quat }}, \mathrm{Ar}-\mathrm{C}\right), 169.8\left(-, \mathrm{C}_{\text {quat }}, \mathrm{C}=\mathrm{O}\right) .-\mathrm{MS}(\mathrm{EI}): \mathrm{m} / z(\%)=212(85)\left[\mathrm{M}^{+}\right], 183(32)$, 122 (32), 91 (100), 80 (45), 69 (50). $-\mathrm{C}_{13} \mathrm{H}_{12} \mathrm{~N}_{2} \mathrm{O}$ (212.25): calcd. C 73.56, H 5.70, N 13.20; found C 73.74, H 5.77, N 13.08.

5-(p-Methoxybenzyl)-6-oxo-5-azaspiro[2.3]hexane-4-carbonitrile (53d): Column chro-

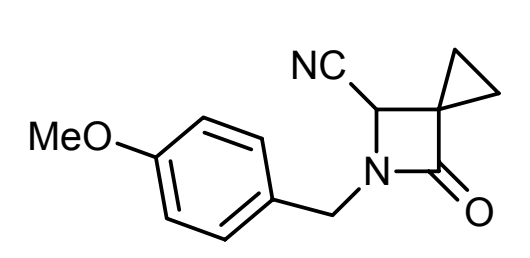
matography $\left(R_{\mathrm{f}}=0.10,44 \mathrm{~g}\right.$ of silica gel, $3 \times 13 \mathrm{~cm}$ column, hexane/ $\mathrm{Et}_{2} \mathrm{O}$ 1.5:1) of the residue obtained from the isoxazolidine $47 \mathrm{~d}(2.00 \mathrm{~g}, 7.40 \mathrm{mmol})$ and TFA $(1.01 \mathrm{~g}$, $0.68 \mathrm{~mL}, 8.88 \mathrm{mmol})$ in acetonitrile $(45 \mathrm{~mL})$ according to $\mathrm{GP} 2$ (12 h) gave the $\beta$-lactam 53d (1.68 g, 94\%) as a colorless solid, m.p. $54-56{ }^{\circ} \mathrm{C}$. - IR (KBr): $\tilde{v}=3003 \mathrm{~cm}^{-1}, 2973,2913,2867,2841,2249,1754,1613,1585,1515 .-{ }^{1} \mathrm{H}$ NMR $(250 \mathrm{MHz}$, $\left.\mathrm{CDCl}_{3}\right): \delta=1.14-1.27\left(\mathrm{~m}, 2 \mathrm{H}, \mathrm{CH}_{2}, \mathrm{cPr}-\mathrm{H}\right), 1.30-1.44\left(\mathrm{~m}, 2 \mathrm{H}, \mathrm{CH}_{2}, \mathrm{cPr}-\mathrm{H}\right), 3.80$ (s, $3 \mathrm{H}$, $\left.\mathrm{OCH}_{3}\right), 4.10(\mathrm{~s}, 1 \mathrm{H}, \mathrm{CH}), 4.18\left(\mathrm{~d},{ }^{2} J_{\mathrm{H}, \mathrm{H}}=15.0 \mathrm{~Hz}, 1 \mathrm{H}, \mathrm{NCH}_{2}\right), 4.75\left(\mathrm{~d},{ }^{2} J_{\mathrm{H}, \mathrm{H}}=15.0 \mathrm{~Hz}, 1 \mathrm{H}\right.$, $\mathrm{NCH}_{2}$ ), 6.84-6.93 (m, $\left.2 \mathrm{H}, \mathrm{Ar}-\mathrm{H}\right), 7.20-7.26$ (m, $\left.2 \mathrm{H}, \mathrm{Ar}-\mathrm{H}\right) .-{ }^{13} \mathrm{C} \mathrm{NMR}\left(62.9 \mathrm{MHz}, \mathrm{CDCl}_{3}\right.$, 
additional DEPT): $\delta=8.2\left(-, \mathrm{CH}_{2}, \mathrm{cPr}-\mathrm{C}\right), 9.0\left(-, \mathrm{CH}_{2}, \mathrm{cPr}-\mathrm{C}\right), 38.2\left(\mathrm{C}_{\text {quat }}, \mathrm{C}-3\right), 45.5$ (-, $\left.\mathrm{NCH}_{2}\right), 46.4(+, \mathrm{CH}), 55.2\left(+, \mathrm{OCH}_{3}\right), 114.3(+, 2 \mathrm{CH}, \mathrm{Ar}-\mathrm{C}), 115.7\left(\mathrm{C}_{\text {quat }}, \mathrm{CN}\right), 125.9\left(\mathrm{C}_{\text {quat }}\right.$, Ar-C), 129.8 (+, 2 CH, Ar-C), 159.5 ( $\left.\mathrm{C}_{\text {quat }}, \mathrm{Ar}-\mathrm{C}\right), 169.6\left(\mathrm{C}_{\text {quat }}, \mathrm{C}=\mathrm{O}\right) .-\mathrm{MS}(\mathrm{EI})$ : $m / z(\%)=242(40)\left[\mathrm{M}^{+}\right], 213(15), 121(100) .-\mathrm{C}_{14} \mathrm{H}_{14} \mathrm{~N}_{2} \mathrm{O}_{2}$ (242.3): calcd. C 69.41, H 5.82, N 11.56; found C 69.14, H 5.61, N 11.37.

5-Benzyl-6-(2-iodophenyl)-5-azaspiro[2.3]hexane-4-one (53e): Column chromatography

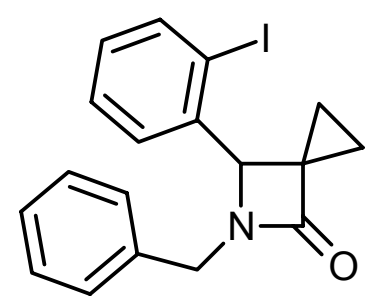
$\left(R_{\mathrm{f}}=0.26,35 \mathrm{~g}\right.$ of silica gel, $3 \times 10 \mathrm{~cm}$ column, hexane/Et $\left.\mathrm{t}_{2} \mathrm{O} 2: 1\right)$ of the residue obtained from the isoxazolidine $47 \mathrm{e}(0.350 \mathrm{~g}, 0.840 \mathrm{mmol})$ and TFA $(0.144 \mathrm{~g}, 0.1 \mathrm{~mL}, 1.26 \mathrm{mmol})$ in acetonitrile $(10 \mathrm{~mL})$ according to GP $2(1 \mathrm{~h})$ gave the $\beta$-lactam $53 \mathrm{e}(0.290 \mathrm{~g}, 89 \%)$ as colorless oil. - IR (film): $\tilde{v}=3062 \mathrm{~cm}^{-1}, 3029,3001,2916,1761$, 1584, 1563, 1455, 1437. - ${ }^{1} \mathrm{H}$ NMR (250 MHz, $\left.\mathrm{CDCl}_{3}\right): \delta=0.37-0.43$ (m, $\left.1 \mathrm{H}, \mathrm{cPr}-\mathrm{H}\right), 1.05$ (m, $1 \mathrm{H}, \mathrm{cPr}-\mathrm{H}), 1.25-1.33$ (m, $2 \mathrm{H}, \mathrm{cPr}-\mathrm{H}), 3.96-4.02\left(\mathrm{~d},{ }^{2} J_{\mathrm{H}, \mathrm{H}}=15.0 \mathrm{~Hz}, 1 \mathrm{H}, \mathrm{NCH}_{2}\right), 4.88-$ $4.94\left(\mathrm{~d},{ }^{2} J_{\mathrm{H}, \mathrm{H}}=15.0 \mathrm{~Hz}, 1 \mathrm{H}, \mathrm{NCH}_{2}\right), 4.91(\mathrm{~s}, 1 \mathrm{H}), 6.98-7.04(\mathrm{~m}, 1 \mathrm{H}, \mathrm{Ar}-\mathrm{H}), 7.22-7.38$ (m, $7 \mathrm{H}, \mathrm{Ar}-\mathrm{H}), 7.77-7.81(\mathrm{~m}, 1 \mathrm{H}, \mathrm{Ar}-\mathrm{H}) .-{ }^{13} \mathrm{C} \mathrm{NMR}\left(62.9 \mathrm{MHz}, \mathrm{CDCl}_{3}\right.$, additional APT): $\delta=6.9\left(-, \mathrm{CH}_{2}, \mathrm{cPr}-\mathrm{C}\right), 9.0\left(-, \mathrm{CH}_{2}, \mathrm{cPr}-\mathrm{C}\right), 41.1$ (-, $\left.\mathrm{C}_{\text {quat }}, \mathrm{C}-3\right), 45.3\left(-, \mathrm{NCH}_{2}\right), 64.2(+$, $\mathrm{CH}), 98.4$ (-, $\left.\mathrm{C}_{\text {quat }}, \mathrm{Ar}-\mathrm{C}\right), 127.4$ (+, $\left.\mathrm{CH}, \mathrm{Ar}-\mathrm{C}\right), 127.7$ (+, $\left.\mathrm{CH}, \mathrm{Ar}-\mathrm{C}\right), 128.5$ (+, $\left.2 \mathrm{CH}, \mathrm{Ar}-\mathrm{C}\right)$, 128.7 (+, CH, Ar-C), 128.8 (+, 2 CH, Ar-C), 129.8 (+, CH, Ar-C), 135.6 (-, C quat, Ar-C), 139.1 (-, $\left.\mathrm{C}_{\text {quat }}, \mathrm{Ar}-\mathrm{C}\right), 139.5$ (CH, Ar-C), 172.9 (-, $\left.\mathrm{C}_{\text {quat }}, \mathrm{C}=\mathrm{O}\right) .-\mathrm{MS}(\mathrm{EI}): \mathrm{m} / z(\%)=389$ (8), 262 (10), 129 (100), 91 (80), 77 (10), 65 (20), 51 (10), 41 (5). - $\mathrm{C}_{18} \mathrm{H}_{16} \mathrm{INO}$ (389.23): calcd; C 55.54, H 4.14, N 3.6; found C 55.80, H 4.16, N 3.73.

1-[1-(2,2,2-Trifluoroacetyl)-pyrrolidin-2-yl]-cyclopropane carboxylic acid (72): Column<smiles>O=C(O)N1CCCC1C1(C(=O)O)CC1</smiles>
chromatography $\left(R_{\mathrm{f}}=0.13,160 \mathrm{~g}\right.$ of silica gel, $5 \times 17 \mathrm{~cm}$ column, $\left.\mathrm{CH}_{2} \mathrm{Cl}_{2} / \mathrm{MeOH} 60: 1+1 \% \mathrm{NH}_{3}\right)$ of the residue obtained from the isoxazolidine $70(6.28 \mathrm{~g}, \quad 38.0 \mathrm{mmol})$ and TFA $(5.24 \mathrm{~g}, 3.5 \mathrm{~mL}$, $46.0 \mathrm{mmol})$ in acetonitrile $(210 \mathrm{~mL})$ according to GP $2(12 \mathrm{~h})$ gave the product $72(1.70 \mathrm{~g}, 18 \%)$ as a colorless solid, m.p. $127-128^{\circ} \mathrm{C} .-\mathrm{IR}(\mathrm{KBr}): \tilde{v}=3423 \mathrm{~cm}^{-1}$, 2979, 1690, 1458, 1141. - ${ }^{1} \mathrm{H}$ NMR (250 MHz, $\left.\mathrm{CDCl}_{3}\right): \delta=0.77-0.83$ (m, $\left.1 \mathrm{H}, \mathrm{CH}_{2}, \mathrm{cPr}-\mathrm{H}\right)$, 1.31-1.44 (m, $2 \mathrm{H}, \mathrm{CH}_{2}$, cPr-H), 1.50-1.56 (m, 1 H, $\left.\mathrm{CH}_{2}, \mathrm{cPr}-\mathrm{H}\right), 1.71-1.87$ (m, $\left.1 \mathrm{H}\right), 2.03-$ $2.26(\mathrm{~m}, 3 \mathrm{H}), 3.69-3.86(\mathrm{~m}, 3 \mathrm{H}) .-{ }^{13} \mathrm{C} \mathrm{NMR}\left(75.5 \mathrm{MHz}, \mathrm{CDCl}_{3}\right.$, additional APT): $\delta=15.3$ (-, $\left.\mathrm{CH}_{2}, \mathrm{cPr}-\mathrm{C}\right), 18.3\left(-, \mathrm{CH}_{2}, \mathrm{cPr}-\mathrm{C}\right), 24.9\left(-,{ }^{*}\right), 25.3(-, *), 29.6(-, *), 48.2\left(-, \mathrm{q},{ }^{4} J_{\mathrm{C}, \mathrm{F}}=\right.$ 
$3.8 \mathrm{~Hz}, \mathrm{C}-3), 62.2(+, \mathrm{C}-1), 116.4\left(-, \mathrm{q},{ }^{1} J_{\mathrm{C}, \mathrm{F}}=287.6 \mathrm{~Hz}, \mathrm{CF}_{3}\right), 156.2\left(-, \mathrm{q},{ }^{2} J_{\mathrm{C}, \mathrm{F}}=36.2 \mathrm{~Hz}\right.$, $\left.\mathrm{COCF}_{3}\right), 179.6(-, \mathrm{C}=\mathrm{O}) .-\mathrm{MS}(\mathrm{EI}): m / z(\%)=251(15)\left[\mathrm{M}^{+}\right], 206(45), 182(50), 166(100)$, 154 (40), 136 (20), 69 (60), 41 (50). - MS (DCI): m/z (\%) = 520 (10) [2 M+ $\left.\mathrm{NH}_{4}{ }^{+}\right], 286(10)$ $\left[\mathrm{M}+\mathrm{NH}_{3}+\mathrm{NH}_{4}^{+}\right], 269(100)\left[\mathrm{M}+\mathrm{NH}_{4}^{+}\right], 252(5)\left[\mathrm{M}+\mathrm{H}^{+}\right]$. 


\subsection{Synthesis of Compounds in Chapter 2}

\section{Reaction of Bicyclopropylidene with in situ generated nitrones. General Procedure 3}

(GP 3): The hydroxylamine salt (1 equiv.), sodium acetate (1 equiv.), formaline (1.5 equiv.) and bicyclopropylidene (1.5 equiv.) were stirred in ethanol (solution $0.3 \mathrm{M}$ ) at room temperature in a sealed tube. After the indicated time the reaction mixture was transferred to a flask and the solvent evaporated to dryness. Equal amounts of water and ethyl acetate were added. The two phases were separated and the water phase was extracted thrice with ethyl acetate, after being basified to $\mathrm{pH}=8$ with a sat. solut. of $\mathrm{NaHCO}_{3}$. The combined organic layers were washed with brine and dried over $\mathrm{Na}_{2} \mathrm{SO}_{4}$, and the crude product was purified by column cromatography.

\section{5-(p-Methoxybenzyl)-5-azaspiro[2.3]hexan-4-one (53g) and 8-(p-Methoxybenzyl)-7-oxa-} 8-aza-dispiro[2.0.2.3]nonane (47g): Column chromatography (42 g of silica gel, $12 \times 3 \mathrm{~cm}$ column, hexane $/ \mathrm{Et}_{2} \mathrm{O} 3: 1$ ) of the residue obtained from hydroxylamine $65 \mathrm{~d} \cdot(\mathrm{COOH})_{2}$ $(0.998 \mathrm{~g}, 4.10 \mathrm{mmol})$, formaldehyde $66-\mathrm{H}$ solution $(12.3 \mathrm{M})$ in water $(0.5 \mathrm{~mL}, 6.15 \mathrm{mmol})$, bicyclopropylidene (24) $(0.58 \mathrm{~mL}, 0.493 \mathrm{~g}, 6.15 \mathrm{mmol})$, and NaOAc $(0.336 \mathrm{~g}, 4.10 \mathrm{mmol})$ in $13.7 \mathrm{~mL}$ of ethanol according to GP $3\left(25^{\circ} \mathrm{C}, 6\right.$ days $)$ gave the product $53 \mathrm{~g}\left(R_{\mathrm{f}}=0.28\right.$, $0.201 \mathrm{~g}, 22 \%)$ and $47 \mathrm{~g}\left(R_{\mathrm{f}}=0.33,0.082 \mathrm{~g}, 8 \%\right)$ as yellow oils.

53g: - IR (KBr): $\tilde{v}=3080 \mathrm{~cm}^{-1}, 3001,2936,2894,2839,1732,1512,1401 .-{ }^{1} \mathrm{H}$ NMR<smiles>COc1ccc(CN2CC3(CC3)C2=O)cc1</smiles>

$\left(250 \mathrm{MHz}, \mathrm{CDCl}_{3}\right): \delta=0.90-0.95(\mathrm{~m}, 2 \mathrm{H}, \mathrm{cPr}-\mathrm{H}), 1.16-1.21$ (m, $2 \mathrm{H}, \mathrm{cPr}-\mathrm{H}), 3.30(\mathrm{~s}, 2 \mathrm{H}), 3.80(\mathrm{~s}, 3 \mathrm{H}), 4.40(\mathrm{~s}, 2 \mathrm{H})$, 6.85-6.91 (m, 2 H, Ar-H), 7.17-7.23 (m, 2 H, Ar-H). $-{ }^{13} \mathrm{C}$ NMR (62.9 $\mathrm{MHz}, \mathrm{CDCl}_{3}$, additional DEPT): $\delta=7.33(-, 2$ $\left.\mathrm{CH}_{2}, \mathrm{cPr}-\mathrm{H}\right), 31.8\left(\mathrm{C}_{\text {quat }}, \mathrm{C}-3\right), 45.6\left(-, \mathrm{NCH}_{2}, *\right), 47.7\left(-, \mathrm{NCH}_{2}, *\right), 55.1\left(+, \mathrm{CH}_{3}\right), 113.9(+$, $2 \mathrm{CH}, \mathrm{Ar}-\mathrm{C}), 127.8\left(\mathrm{C}_{\text {quat }}, \mathrm{Ar}-\mathrm{C}\right), 129.2$ (+, $\left.2 \mathrm{CH}, \mathrm{Ar}-\mathrm{C}\right), 158.9\left(\mathrm{C}_{\text {quat }}, \mathrm{Ar}-\mathrm{C}\right), 172.3\left(\mathrm{C}_{\text {quat }}\right.$, $\mathrm{C}=\mathrm{O}) .-\mathrm{MS}(\mathrm{EI}): m / z(\%)=217$ (100), $186(8), 163(10), 121$ (85), 78 (10). - $\mathrm{C}_{13} \mathrm{H}_{15} \mathrm{NO}_{2}$ (217.26): calcd. C 71.87, H 6.96, N 6.45; found C 72.07, H 7.10, N 6.30. 
5-Benzyl-5-azaspiro[2.3]hexan-4-one (53j): Column chromatography (25 g of silica gel,

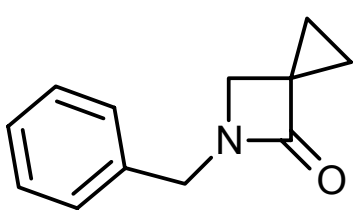

$15 \times 2 \mathrm{~cm}$ column, hexane/ $\mathrm{Et}_{2} \mathrm{O} 2: 1$ ) of the residue obtained from hydroxylamine $\mathbf{6 5 c} \cdot \mathbf{H C l}(0.499 \mathrm{~g}, 3.13 \mathrm{mmol})$, formaldehyde $\mathbf{6 6}-\mathrm{H}$ solution $(12.3 \mathrm{M})$ in water $(0.380 \mathrm{~mL}, 4.67 \mathrm{mmol})$, bicyclopropylidene (24) $(0.440 \mathrm{~mL}, 0.374 \mathrm{~g}, 4.67 \mathrm{mmol})$, and NaOAc (0.257 g, 3.13 mmol) in $10.9 \mathrm{~mL}$ of ethanol according to GP $3\left(25^{\circ} \mathrm{C}, 8\right.$ days $)$ gave the product $\mathbf{5 3 \mathbf { j }}$ $\left(R_{\mathrm{f}}=0.23,0.144 \mathrm{~g}, 25 \%\right)$ as a yellow oil. - IR (film): $\tilde{v}=3064 \mathrm{~cm}^{-1}, 3004,2890,1751,1496$, 1455, 1395, 1354. $-{ }^{1} \mathrm{H}$ NMR (250 MHz, $\left.\mathrm{CDCl}_{3}\right): \delta=0.92-0.97$ (m, $\left.2 \mathrm{H}, \mathrm{cPr}-\mathrm{H}\right), 1.18-1.23$ (m, $2 \mathrm{H}, \mathrm{cPr}-\mathrm{H}), 3.33$ (s, $\left.2 \mathrm{H}, \mathrm{CH}_{2}\right), 4.47$ (s, $\left.2 \mathrm{H}, \mathrm{CH}_{2}\right), 7.17-7.39$ (m, $\left.5 \mathrm{H}, \mathrm{Ar}-\mathrm{H}\right) .-{ }^{13} \mathrm{C} \mathrm{NMR}$ (62.9 MHz, $\mathrm{CDCl}_{3}$, additional DEPT): $\delta=7.6\left(-, 2 \mathrm{CH}_{2}, \mathrm{cPr}-\mathrm{C}\right), 32.1$ ( $\left.\mathrm{C}_{\text {quat }}, \mathrm{C}-3\right), 46.3(-$, $\left.\mathrm{NCH}_{2}, *\right), 48.1\left(-, \mathrm{NCH}_{2},{ }^{*}\right), 127.6$ (+, $\left.\mathrm{CH}, \mathrm{Ar}-\mathrm{C}\right), 128.1$ (+, $\left.2 \mathrm{CH}, \mathrm{Ar}-\mathrm{C}\right), 128.7$ (+, $2 \mathrm{CH}$, Ar-C), $136.0\left(\mathrm{C}_{\text {quat }}, \mathrm{Ar}-\mathrm{C}\right), 172.6\left(\mathrm{C}_{\text {quat }}, \mathrm{C}=\mathrm{O}\right) .-\mathrm{MS}(\mathrm{EI}): \mathrm{m} / z(\%)=187$ (44), 131 (10), 91 (100), 54 (21). $-\mathrm{C}_{12} \mathrm{H}_{13} \mathrm{NO}$ (187.24): calcd. C 76.98, H 7.00, N 7.48; found $\mathrm{C} 76.83, \mathrm{H}$ 7.13, N 7.25.

Synthesis of $\beta$-lactams by reaction of Bicyclopropylidene with in situ generated nitrones under traditional heating. General Procedure 4

(GP 4): The hydroxylamine salt (1 equiv.), sodium acetate (1 equiv.), formaline (1.5 equiv.) and bicyclopropylidene ( 1.5 equiv.) were stirred in ethanol (solution $0.3 \mathrm{M}$ ) at the indicated temperature in a sealed tube. After the indicated time the reaction mixture was transferred to a flask and the solvent evaporated to dryness. Equal amounts of water and ethyl acetate were added. The two phases were separated and the water phase was extracted thrice with ethyl acetate, after being basified to $\mathrm{pH}=8$ with a sat. solution of $\mathrm{NaHCO}_{3}$. After that, the combined organic layers were washed with brine, dried over sodium sulfate, and the crude product was purified by column cromatography.

5-(p-Methoxybenzyl)-5-azaspiro[2.3]hexan-4-one (53g): Column chromatography (20 g of silica gel, $12 \times 1 \mathrm{~cm}$ column, hexane/ $\mathrm{Et}_{2} \mathrm{O} 3: 1$ ) of the residue obtained from hydroxylamine 65d $\cdot(\mathbf{C O O H})_{2}(0.280 \mathrm{~g}, 1.15 \mathrm{mmol})$, formaldehyde $(66-\mathrm{H})$ solution $(12.3 \mathrm{M})$ in water (0.14 mL, $1.72 \mathrm{mmol})$, bicyclopropylidene (24) (0.16 mL, $0.138 \mathrm{~g}, 1.72 \mathrm{mmol})$, and NaOAc $(0.094 \mathrm{~g}, 1.15 \mathrm{mmol})$ in $4.0 \mathrm{~mL}$ of ethanol according to $\mathrm{GP} 4\left(45^{\circ} \mathrm{C}, 7\right.$ days $)$ gave the product $\mathbf{5 3 g}\left(R_{\mathrm{f}}=0.28,0.075 \mathrm{~g}, 30 \%\right)$ as a yellow oil. 
5-Benzyl-5-azaspiro[2.3]hexan-4-one (53j): Column chromatography (25 g of silica gel, $15 \times 2 \mathrm{~cm}$ column, hexane $/ \mathrm{Et}_{2} \mathrm{O} 2: 1$ ) of the residue obtained from hydroxylamine $\mathbf{6 5 c} \cdot \mathbf{H C l}$ $(0.499 \mathrm{~g}, 3.13 \mathrm{mmol})$, formaldehyde $66-\mathrm{H}$ solution $(12.3 \mathrm{M})$ in water $(0.380 \mathrm{~mL}, 4.67 \mathrm{mmol})$, bicyclopropylidene (24) $(0.440 \mathrm{~mL}, 0.374 \mathrm{~g}, 4.67 \mathrm{mmol})$, and $\mathrm{NaOAc}(0.257 \mathrm{~g}, 3.13 \mathrm{mmol})$ in $10.9 \mathrm{~mL}$ of ethanol according to $\mathrm{GP} 4\left(50^{\circ} \mathrm{C}, 5\right.$ days $)$ gave the product $\mathbf{5 3 \mathbf { j }}\left(R_{\mathrm{f}}=0.23\right.$, $0.194 \mathrm{~g}, 33 \%$ ) as a yellow oil.

Synthesis of $\beta$-lactams by reaction of Bicyclopropylidene with in situ generated nitrones under high pressure. General Procedure 5

(GP 5): The hydroxylamine salt (1 equiv.), sodium acetate (1 equiv.), formaline (2.0 equiv.) and bicyclopropylidene (2.0 equiv.) were mantained in ethanol (solution $0.3 \mathrm{M}$ ) at room temperature in a sealed teflon-tube under $10 \mathrm{Kbar}$ pressure. After $24 \mathrm{~h}$ the reaction mixture was transferred to a flask and the solvent evaporated to dryness. Equal amounts of water and ethyl acetate were added. The two phases were separated and the water phase was washed thrice with ethyl acetate, after being basified to $\mathrm{pH}=8$ with a sat. solution of $\mathrm{NaHCO}_{3}$. After that the combined organic layers were washed with brine, dried over sodium sulfate and the crude product was purified by column cromatography.

5-(p-Methoxybenzyl)-5-azaspiro[2.3]hexan-4-one (53g): Column chromatography (25 g of silica gel, $2 \times 15 \mathrm{~cm}$ column, hexane/ $\operatorname{Et}_{2} \mathrm{O} 3: 1$ ) of the residue obtained from hydroxylamine 65d $\cdot(\mathbf{C O O H})_{2}(0.243 \mathrm{~g}, 1.00 \mathrm{mmol})$, formaldehyde $(66-\mathrm{H})$ solution $(8 \mathrm{M})$ in water $(0.25 \mathrm{~mL}$, $2.00 \mathrm{mmol})$, bicyclopropylidene $(\mathbf{2 4})(0.19 \mathrm{~mL}, 0.160 \mathrm{~g}, 2.00 \mathrm{mmol})$, and $\mathrm{NaOAc}(0.082 \mathrm{~g}$, $1.00 \mathrm{mmol})$ in $3.5 \mathrm{~mL}$ of ethanol according to GP $5\left(25^{\circ} \mathrm{C}\right)$ gave the product $\mathbf{5 3 g}\left(R_{\mathrm{f}}=0.28\right.$, $0.062 \mathrm{~g}, 28 \%$ ) as a yellow oil.

5-Benzyl-5-azaspiro[2.3]hexan-4-one (53j): Column chromatography (20 g of silica gel, $11 \times 2 \mathrm{~cm}$ column, hexane/Et $\left.\mathrm{Et}_{2} \mathrm{O} 2: 1\right)$ of the residue obtained from hydroxylamine $\mathbf{6 5 c} \cdot \mathbf{H C l}$ $(0.160 \mathrm{~g}, 1.00 \mathrm{mmol})$, formaldehyde $66-\mathrm{H}$ solution $(8.0 \mathrm{M})$ in water $(0.25 \mathrm{~mL}, 2.00 \mathrm{mmol})$, bicyclopropylidene (24) $(0.190 \mathrm{~mL}, 0.160 \mathrm{~g}, 2.00 \mathrm{mmol})$, and NaOAc (0.082 g, $1.00 \mathrm{mmol})$ in $3.5 \mathrm{~mL}$ of ethanol according to GP $5\left(25^{\circ} \mathrm{C}\right)$ gave the product $53 \mathbf{j}\left(R_{\mathrm{f}}=0.23,0.041 \mathrm{~g}\right.$, $22 \%$ ) as a yellow oil. 
Microwave assisted one-pot three-component synthesis of $\beta$-lactams 53g,j, 53e-H,f-H, 77c-Et,f-Et and 77d-Me. General Procedure 6

(GP 6): A solution of the hydroxylamine salt (2 equiv.), the aldehyde (2 equiv.), bicyclopropylidene (24) (1 equiv.), and $\mathrm{NaOAc}$ (2 equiv.) in ethanol was sealed in a screw-capped vial for the microwave apparatus and heated at the indicated temperature for the indicated time. After cooling down to room temperature, the solution was concentrated under reduced pressure. An equal amount each of water and ethyl acetate was added, and the two phases were separated. The water phase was made basic with a satd. solution of $\mathrm{NaHCO}_{3}$ and extracted three times with ethyl acetate. The combined organic layers were then washed with brine, dried over $\mathrm{Na}_{2} \mathrm{SO}_{4}$ and the crude product was purified by column cromatography.

5-(p-Methoxybenzyl)-5-azaspiro[2.3]hexan-4-one (53g): Column chromatography $\left(R_{\mathrm{f}}=0.28,30 \mathrm{~g}\right.$ of silica gel, $12 \times 2.5 \mathrm{~cm}$ column, hexane/Et $\left.\mathrm{E}_{2} \mathrm{O} 3: 1\right)$ of the residue obtained from hydroxylamine $\mathbf{6 5 d} \cdot(\mathbf{C O O H})_{2}(0.780 \mathrm{~g}, 3.20 \mathrm{mmol})$, formaldehyde $(\mathbf{6 6}-\mathrm{H})$ solution $(8.0 \mathrm{M})$ in water $(0.250 \mathrm{~mL}, 2.00 \mathrm{mmol})$, bicyclopropylidene (24) $(0.190 \mathrm{~mL}, 0.160 \mathrm{~g}$, $2.00 \mathrm{mmol})$, and NaOAc $(0.263 \mathrm{~g}, 3.20 \mathrm{mmol})$ in $2.50 \mathrm{~mL}$ of ethanol according to GP 6 $\left(80{ }^{\circ} \mathrm{C}, 45 \mathrm{~min}\right)$ gave the product $\mathbf{5 3 g}(0.232 \mathrm{~g}, 53 \%)$ as a yellow oil.

5-Benzyl-5-azaspiro[2.3]hexan-4-one (53j): Column chromatography $\left(R_{\mathrm{f}}=0.29,45 \mathrm{~g}\right.$ of silica gel, $12 \times 3 \mathrm{~cm}$ column, hexane/ $\mathrm{Et}_{2} \mathrm{O} 2: 1$ ) of the residue obtained from hydroxylamine 65. HCl $(0.638 \mathrm{~g}, 4.00 \mathrm{mmol})$, formaldehyde $66-\mathrm{H}$ solution $(8.0 \mathrm{M})$ in water $(0.250 \mathrm{~mL}$, $2.00 \mathrm{mmol})$, bicyclopropylidene $(\mathbf{2 4})(0.190 \mathrm{~mL}, 0.160 \mathrm{~g}, 2.00 \mathrm{mmol})$, and $\mathrm{NaOAc}(0.328 \mathrm{~g}$, $4.00 \mathrm{mmol})$ in $1.75 \mathrm{~mL}$ of ethanol according to $\mathrm{GP} 6\left(100^{\circ} \mathrm{C}, 60 \mathrm{~min}\right)$ gave the product $\mathbf{5 3 j}$ $(0.255 \mathrm{~g}, 68 \%)$ as a yellow oil.

5-(Benzhydryl)-5-azaspiro[2.3]hexan-4-one (53e-H): Column chromatography $\left(R_{\mathrm{f}}=0.18\right.$,

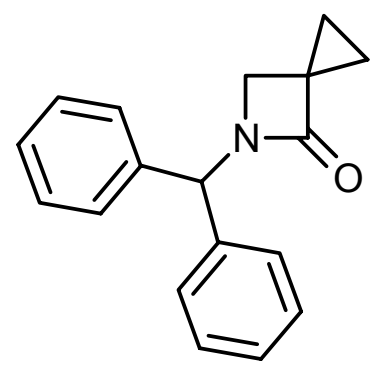
$36 \mathrm{~g}$ of silica gel, $15 \times 2.5 \mathrm{~cm}$ column, hexane $\left./ \mathrm{Et}_{2} \mathrm{O} 2: 1\right)$ of the residue obtained from hydroxylamine $\mathbf{6 5 e} \cdot \mathbf{H C l} \quad(0.707 \mathrm{~g}$, $3.00 \mathrm{mmol})$, formaldehyde $(66-\mathrm{H})$ solution $(8.0 \mathrm{M})$ in water $(0.375 \mathrm{~mL}, \quad 3.00 \mathrm{mmol})$, bicyclopropylidene $\mathbf{( 2 4 )} \quad(0.140 \mathrm{~mL}$, $1.50 \mathrm{mmol})$, and $\mathrm{NaOAc}(0.246 \mathrm{~g}, 3.00 \mathrm{mmol})$ in $2.00 \mathrm{~mL}$ of ethanol according to GP $6\left(100{ }^{\circ} \mathrm{C}, 30 \mathrm{~min}\right)$ gave the product $53 \mathrm{e}-\mathrm{H}$ (193 mg, 49\%) as a colorless solid, m.p. 95-96 ${ }^{\circ} \mathrm{C}$. - IR (KBr): $\tilde{v}=3080 \mathrm{~cm}^{-1}, 3060,2962$, 2892, 1888, 1745, 1597, 1581, 1494, 1446, 1384, 1364. - ${ }^{1} \mathrm{H}$ NMR $\left(250 \mathrm{MHz}, \mathrm{CDCl}_{3}\right)$ : 
$\delta=0.93-0.98(\mathrm{~m}, 2 \mathrm{H}, \mathrm{cPr}-\mathrm{H}), 1.20-1.25(\mathrm{~m}, 2 \mathrm{H}, \mathrm{cPr}-\mathrm{H}), 3.39$ (s, $\left.2 \mathrm{H}, \mathrm{CH}_{2}\right), 6.25$ (s, $1 \mathrm{H}$, $\mathrm{CH}), 7.02-7.28$ (m, $5 \mathrm{H}, \mathrm{Ar}-\mathrm{H}$ ), 7.30-7.40 (m, $5 \mathrm{H}, \mathrm{Ar}-\mathrm{H}) .-{ }^{13} \mathrm{C} \mathrm{NMR}\left(62.9 \mathrm{MHz}, \mathrm{CDCl}_{3}\right.$, additional DEPT): $\delta=7.8\left(-, 2 \mathrm{CH}_{2}, \mathrm{cPr}-\mathrm{H}\right), 31.4\left(\mathrm{C}_{\text {quat }}, \mathrm{C}-3\right), 47.4\left(-, \mathrm{CH}_{2}\right), 59.3(+, \mathrm{CH})$, $127.6(+, 2 \mathrm{CH}, \mathrm{Ar}-\mathrm{C}), 128.1$ (+, $4 \mathrm{CH}, \mathrm{Ar}-\mathrm{C}), 128.6$ (+, $4 \mathrm{CH}, \mathrm{Ar}-\mathrm{C}), 139.2\left(2 \mathrm{C}_{\text {quat }}, \mathrm{Ar}-\mathrm{C}\right)$, $172.5\left(\mathrm{C}_{\text {quat }}, \mathrm{C}=\mathrm{O}\right) .-\mathrm{MS}(\mathrm{EI}): \mathrm{m} / z(\%)=263$ (45), 186 (20), 167 (100), 165 (25), 152 (18), 91 (18). $-\mathrm{C}_{18} \mathrm{H}_{17} \mathrm{NO}$ (263.33): calcd. C 82.10, H 6.51, N 5.32; found C 82.12, H 6.25, N 5.16.

5-tert-Butyl-5-azaspiro[2.3]hexan-4-one (53f-H): Column chromatography $\left(R_{\mathrm{f}}=0.19,25 \mathrm{~g}\right.$

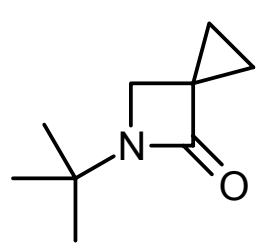
of silica gel, $12 \times 2 \mathrm{~cm}$ column, hexane/ $\mathrm{Et}_{2} \mathrm{O} 2: 1$ ) of the residue obtained from hydroxylamine $\mathbf{6 5 f} \cdot \mathbf{H C l}(0.251 \mathrm{~g}, 2.00 \mathrm{mmol})$, formaldehyde $(\mathbf{6 6}-\mathrm{H})$ solution $(8.0 \mathrm{M})$ in water $(0.25 \mathrm{~mL}, 2.00 \mathrm{mmol})$, bicyclopropylidene (24) $(0.09 \mathrm{~mL}, 1.00 \mathrm{mmol})$, and NaOAc $(0.164 \mathrm{~g}, 2.00 \mathrm{mmol})$ in $0.5 \mathrm{~mL}$ of ethanol according to GP $6\left(80^{\circ} \mathrm{C}, 30 \mathrm{~min}\right)$ gave the product $\mathbf{5 3 f}-\mathrm{H}(0.111 \mathrm{~g}, 73 \%)$ as a colorless oil. - IR (film): $\tilde{v}=2970 \mathrm{~cm}^{-1}, 2935,2885,2839,1753,1379,1336 .-{ }^{1} \mathrm{H}$ NMR $\left(250 \mathrm{MHz}, \mathrm{CDCl}_{3}\right): \delta=0.87-0.91(\mathrm{~m}, 2 \mathrm{H}, \mathrm{cPr}-\mathrm{H}), 1.09-1.14(\mathrm{~m}, 2 \mathrm{H}, \mathrm{cPr}-\mathrm{H}), 1.35(\mathrm{~s}, 9 \mathrm{H}, 3$ $\left.\mathrm{CH}_{3}\right), 3.35(\mathrm{~s}, 2 \mathrm{H}) .-{ }^{13} \mathrm{C} \mathrm{NMR}\left(62.9 \mathrm{MHz}, \mathrm{CDCl}_{3}\right.$, additional DEPT): $\delta=7.3\left(-, 2 \mathrm{CH}_{2}, \mathrm{cPr}-\right.$ C), $27.9\left(+, 3 \mathrm{CH}_{3}\right), 30.2\left(\mathrm{C}_{\text {quat }}, \mathrm{C}-3\right), 45.5\left(-, \mathrm{NCH}_{2}\right), 64.3\left(\mathrm{C}_{\text {quat }}\right), 171.3\left(\mathrm{C}_{\text {quat }}, \mathrm{C}=\mathrm{O}\right)$. MS (EI): $m / z(\%)=153(10), 138$ (100), 84 (5), 70 (100), 57 (40). - HRMS (EI) calcd. for $\mathrm{C}_{9} \mathrm{H}_{15} \mathrm{NO} 153.1154\left[\mathrm{M}^{+}\right]$, found 153.1154 .

Ethyl 5-benzyl-6-oxo-5-azaspiro[2.3]hexane-4-carboxylate (77c-Et): Column chromato-

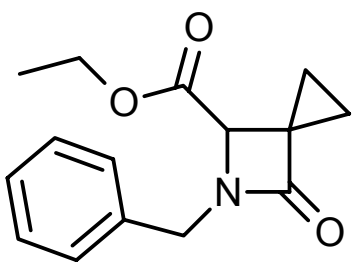
graphy $\left(R_{\mathrm{f}}=0.29,35 \mathrm{~g}\right.$ of silica gel, $12 \times 2.5 \mathrm{~cm}$ column, hexane $/ \mathrm{Et}_{2} \mathrm{O}$ $3: 1)$ of the residue obtained from hydroxylamine $\mathbf{6 5 c} \cdot \mathbf{H C l}(0.479 \mathrm{~g}$, $3.00 \mathrm{mmol})$, ethyl glyoxylate $(\mathbf{7 3}-\mathrm{Et})$ as a solution in toluene $(50 \%$ weight) $(0.60 \mathrm{~mL}, 3.00 \mathrm{mmol})$, bicyclopropylidene (24) $(0.140 \mathrm{~mL}$, $1.50 \mathrm{mmol})$, and $\mathrm{NaOAc}(0.246 \mathrm{~g}, 3.00 \mathrm{mmol})$ in $0.70 \mathrm{~mL}$ of ethanol according to GP 6 $\left(80{ }^{\circ} \mathrm{C}, 15 \mathrm{~min}\right)$ gave the product $77 \mathrm{c}$-Et $(0.279 \mathrm{~g}, 72 \%)$ as a yellow oil. - IR (film): $\tilde{v}=2981 \mathrm{~cm}^{-1}, 1775,1744,1496,1456,1388,1199 .-{ }^{1} \mathrm{H}$ NMR $\left(300 \mathrm{MHz}, \mathrm{CDCl}_{3}\right): \delta=0.84$ $0.90\left(\mathrm{ddd},{ }^{2} J_{\mathrm{H}, \mathrm{H}}=9.4,{ }^{3} J_{\mathrm{H}, \mathrm{H}}=7.8,4.2 \mathrm{~Hz}, 1 \mathrm{H}, \mathrm{cPr}-\mathrm{H}\right), 1.04-1.28(\mathrm{~m}, 3 \mathrm{H}, \mathrm{cPr}-\mathrm{H}), 1.20-1.25$ $\left(\mathrm{t},{ }^{3} J_{\mathrm{H}, \mathrm{H}}=9.0 \mathrm{~Hz}, 3 \mathrm{H}, \mathrm{CH}_{3}\right), 3.98(\mathrm{~s}, 1 \mathrm{H}), 4.10-4.21\left(\mathrm{~m}, 2 \mathrm{H}, \mathrm{OCH}_{2}\right), 4.21-4.25(\mathrm{~d}$, $\left.{ }^{2} J_{\mathrm{H}, \mathrm{H}}=12.0 \mathrm{~Hz}, 1 \mathrm{H}, \mathrm{NCH}_{2}\right), 4.86-4.91\left(\mathrm{~d},{ }^{2} J_{\mathrm{H}, \mathrm{H}}=12.0 \mathrm{~Hz}, 1 \mathrm{H}, \mathrm{NCH}_{2}\right), 7.22-7.36(\mathrm{~m}, 5 \mathrm{H}$, Ar-H). $-{ }^{13} \mathrm{C}$ NMR (75.5 MHz, $\mathrm{CDCl}_{3}$, additional APT): $\delta=6.4\left(-, \mathrm{CH}_{2}, \mathrm{cPr}-\mathrm{C}\right), 8.0\left(-, \mathrm{CH}_{2}\right.$, cPr-C), $14.2\left(+, \mathrm{CH}_{3}\right), 37.2\left(-, \mathrm{C}_{\text {quat }}, \mathrm{C}-3\right), 45.6\left(-, \mathrm{NCH}_{2}\right), 57.5(+, \mathrm{CH}), 61.3\left(-, \mathrm{OCH}_{2}\right)$, 
$127.8(+, \mathrm{CH}, \mathrm{Ar}-\mathrm{C}), 128.4(+, 2 \mathrm{CH}, \mathrm{Ar}-\mathrm{C}), 128.8$ (+, $2 \mathrm{CH}, \mathrm{Ar}-\mathrm{C}), 135.3$ (-, $\left.\mathrm{C}_{\text {quat }}, \mathrm{Ar}-\mathrm{C}\right)$, $169.6(-, \mathrm{C}=\mathrm{O}, *), 171.1\left(-, \mathrm{C}=\mathrm{O},{ }^{*}\right) .-\mathrm{MS}(\mathrm{EI}): m / z(\%)=259$ (4), 231 (18), 186 (5), 158 (39), 91 (100), 65 (15). - $\mathrm{C}_{15} \mathrm{H}_{17} \mathrm{NO}_{3}$ (259.30): calcd. C 69.48, H 6.61, N 5.40; found $\mathrm{C} 68.76$, H 6.72, N 5.52. - HRMS (EI) calcd. for $\mathrm{C}_{15} \mathrm{H}_{17} \mathrm{NO}_{3} 260.1281\left[\mathrm{M}+\mathrm{H}^{+}\right]$, found 260.1281.

\section{One-pot protocol applied to hydroxylamine $65 f \cdot \mathrm{HCl}$ and ethyl glyoxylate $73-\mathrm{Et}$ : A} solution of tert-butylhydroxylamine hydrochloride $(\mathbf{6 5 f} \cdot \mathbf{H C l})(250 \mathrm{mg}, 2.00 \mathrm{mmol})$, ethyl glyoxylate $(73-\mathrm{Et})$ as a toluene solution $(50 \% \mathrm{ww})(0.408 \mathrm{~g}, 0.40 \mathrm{~mL}, 2.0 \mathrm{mmol})$, bicyclopropylidene (24) $(80 \mathrm{mg}, 0.090 \mathrm{~mL}, 1.00 \mathrm{mmol})$ and $\mathrm{NaOAc}(164 \mathrm{mg}, 2.0 \mathrm{mmol})$ in ethanol $(0.50 \mathrm{~mL})$, was sealed in a screw capped vial for the microwave oven and heated at $80{ }^{\circ} \mathrm{C}$ for 105 min. After cooling to room temperature, the solution was concentrated under reduced pressure. An equal amount each of water and ethyl acetate $(30 \mathrm{~mL})$ was added, and the two phases were separated. The water phase was made basic with $\mathrm{NaHCO}_{3}$ (satd. solution) and extracted with ethyl acetate $(3 \times 30 \mathrm{~mL})$. The combined organic layers were then washed with brine and dried over $\mathrm{Na}_{2} \mathrm{SO}_{4}$. The crude product was purified by column chromatography (50 $\mathrm{g}$ of flash silica gel, $3 \times 15 \mathrm{~cm}$ column, hexane/ $\mathrm{Et}_{2} \mathrm{O} 3: 1$ ) to give ethyl 8-tert-butyl-7-oxa-8azadispiro[2.0.2.3]nonane-9-carboxylate (47f-Et) and ethyl 5-tert-butyl-8-oxo-5-aza-

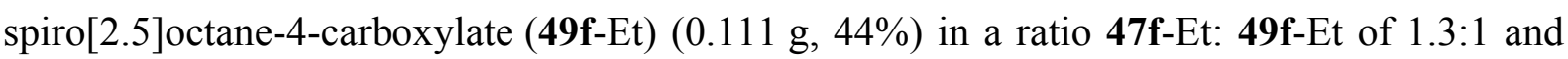
ethyl 5-tert-butyl-6-oxo-5-azaspiro[2.3]hexane-4-carboxylate (77f-Et) $(0.119 \mathrm{~g}, 53 \%)$ as a yellow solid. The product 49f-Et couldn't be separated from the mixture and characterized.

(47f-Et): M.p. $58-60{ }^{\circ} \mathrm{C}$. - IR (film): $\tilde{v}=3076 \mathrm{~cm}^{-1}, 2977,2936,1757,1724,1465,1363$,

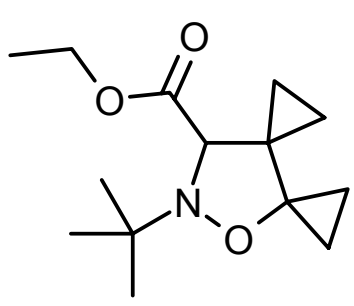
1275. - ${ }^{1} \mathrm{H}$ NMR $\left(600 \mathrm{MHz}, \mathrm{CDCl}_{3}\right): \delta=0.09-0.13 \quad(\mathrm{ddd}$, $\left.{ }^{2} J_{\mathrm{H}, \mathrm{H}}=10.5,{ }^{3} J_{\mathrm{H}, \mathrm{H}}=7.2,6.3 \mathrm{~Hz}, 1 \mathrm{H}, \mathrm{cPr}-\mathrm{H}\right), 0.15-0.18(\mathrm{~m}, 1 \mathrm{H}, \mathrm{cPr}-$ $\mathrm{H}), 0.50-0.54\left(\mathrm{ddd},{ }^{2} J_{\mathrm{H}, \mathrm{H}}=10.5,{ }^{3} J_{\mathrm{H}, \mathrm{H}}=7.1,5.6 \mathrm{~Hz}, 1 \mathrm{H}, \mathrm{cPr}-\mathrm{H}\right)$, $0.65-0.70(\mathrm{~m}, 3 \mathrm{H}, \mathrm{cPr}-\mathrm{H}), 0.82-0.86\left(\mathrm{dt},{ }^{2} J_{\mathrm{H}, \mathrm{H}}=11.2,{ }^{3} J_{\mathrm{H}, \mathrm{H}}=6.7 \mathrm{~Hz}\right.$, $1 \mathrm{H}), 0.90-0.94\left(\mathrm{ddd},{ }^{2} J_{\mathrm{H}, \mathrm{H}}=11.2,{ }^{3} J_{\mathrm{H}, \mathrm{H}}=7.2,5.6 \mathrm{~Hz}, 1 \mathrm{H}, \mathrm{cPr}-\mathrm{H}\right)$, $1.13\left(\mathrm{~s}, 9 \mathrm{H}, 3 \mathrm{CH}_{3}\right), 1.24-1.26\left(\mathrm{t},{ }^{3} J_{\mathrm{H}, \mathrm{H}}=7.2 \mathrm{~Hz}, 3 \mathrm{H}, \mathrm{CH}_{3}\right), 3.69$ (s, $\left.1 \mathrm{H}\right), 4.14-4.19$ (dq, $\left.{ }^{3} J_{\mathrm{H}, \mathrm{H}}=10.5,{ }^{2} J_{\mathrm{H}, \mathrm{H}}=7.1 \mathrm{~Hz}, 1 \mathrm{H}, \mathrm{CH}_{2}\right), 4.23-4.28\left(\mathrm{dq},{ }^{3} J_{\mathrm{H}, \mathrm{H}}=10.5,{ }^{2} J_{\mathrm{H}, \mathrm{H}}=7.1 \mathrm{~Hz}, 1 \mathrm{H}, \mathrm{CH}_{2}\right)$. $-{ }^{13} \mathrm{C} \mathrm{NMR}\left(62.9 \mathrm{MHz}, \mathrm{CDCl}_{3}\right.$, additional APT): $\delta=4.7\left(-, \mathrm{CH}_{2}, \mathrm{cPr}-\mathrm{C}\right), 5.1\left(-, \mathrm{CH}_{2}, \mathrm{cPr}-\mathrm{C}\right)$, $11.4\left(-, \mathrm{CH}_{2}, \mathrm{cPr}-\mathrm{C}\right), 12.2\left(-, \mathrm{CH}_{2}, \mathrm{cPr}-\mathrm{C}\right), 14.3\left(+, \mathrm{CH}_{3}\right), 25.4\left(+, 3 \mathrm{CH}_{3}\right), 31.3\left(-, \mathrm{C}_{\text {quat }}, \mathrm{C}-\right.$ 3), 58.8 (-, $\left.\mathrm{C}_{\text {quat }}\right), 60.9\left(-, \mathrm{OCH}_{2}\right), 65.7$ (-, $\left.\mathrm{C}_{\text {quat }}, \mathrm{C}-6\right), 67.9(+, \mathrm{CH}), 171.7\left(\mathrm{C}_{\text {quat }}, \mathrm{C}=\mathrm{O}\right) .-$ MS (EI): $m / z(\%)=253$ (15), 210 (5), 180 (40), 124 (100), 96 (45), 57 (100), 41 (75). $\mathrm{C}_{14} \mathrm{H}_{23} \mathrm{NO}_{3}$ (253.34): calcd. C 66.37, H 9.15, N 5.53; found C 66.15, H 9.09, N 5.47. 
(77f-Et): $\left(R_{\mathrm{f}}=0.7\right.$, hexane/Et $\left.2 \mathrm{O} 3: 1\right) .-$ IR (film): $\tilde{v}=2937 \mathrm{~cm}^{-1}, 1766,1749,1368,1186$.

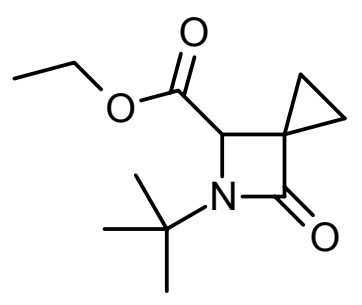

${ }^{1} \mathrm{H}$ NMR $\left(250 \mathrm{MHz}, \mathrm{CDCl}_{3}\right): \delta=0.68-0.74(\mathrm{~m}, 1 \mathrm{H}, \mathrm{cPr}-\mathrm{H}), 1.05-$ $1.24(\mathrm{~m}, 3 \mathrm{H}, \mathrm{cPr}-\mathrm{H}), 1.28\left(\mathrm{t},{ }^{3} J_{\mathrm{H}, \mathrm{H}}=7.5 \mathrm{~Hz}, 3 \mathrm{H}, \mathrm{CH}_{3}\right), 1.37(\mathrm{~s}, 9 \mathrm{H}$, $\left.3 \mathrm{CH}_{3}\right), 4.18(\mathrm{~s}, 1 \mathrm{H}), 4.21\left(\mathrm{dq},{ }^{2} J_{\mathrm{H}, \mathrm{H}}=7.5,{ }^{3} J_{\mathrm{H}, \mathrm{H}}=2.5 \mathrm{~Hz}, 2 \mathrm{H}\right) .-{ }^{13} \mathrm{C}$ NMR (62.9 MHz, $\mathrm{CDCl}_{3}$, additional APT): $\delta=6.4\left(-, \mathrm{CH}_{2}, \mathrm{cPr}-\mathrm{C}\right)$, $8.0\left(-, \mathrm{CH}_{2}, \mathrm{cPr}-\mathrm{C}\right), 14.3\left(+, \mathrm{CH}_{3}\right), 27.9\left(+, 3 \mathrm{CH}_{3}\right), 35.6\left(-, \mathrm{C}_{\text {quat }}, \mathrm{C}-\right.$ 3), $54.3\left(-,{ }^{*}\right), 57.8(+, \mathrm{CH}), 61.3\left(-,{ }^{*}\right), 170.5\left(-, \mathrm{C}=\mathrm{O},{ }^{*}\right), 171.0\left(-, \mathrm{C}=\mathrm{O},{ }^{*}\right) .-\mathrm{MS}(\mathrm{EI}): m / z$ $(\%)=225$ (15), 210 (80), 182 (100), 152 (35), 136 (20), 96 (40), 41 (35). - $\mathrm{C}_{12} \mathrm{H}_{19} \mathrm{NO}_{3}$ (225.29): calcd. C 63.98, H 8.50, N 6.22; found C 64.07, H 8.73, N 6.01.

Methyl 5-(4-methoxybenzyl)-6-oxo-5-azaspiro[2.3]hexane-4-carboxylate (77d-Me): Co-

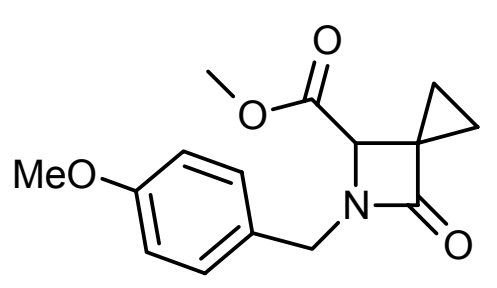
lumn chromatography $\left(R_{\mathrm{f}}=0.12,70 \mathrm{~g}\right.$ of flash silica gel, $20 \times 3 \mathrm{~cm}$ column, hexane/ $\mathrm{Et}_{2} \mathrm{O} 3: 2$ ) of the residue obtained from hydroxylamine $\mathbf{6 5 d} \cdot(\mathbf{C O O H})_{2} \quad(0.486 \mathrm{~g}, 2.00 \mathrm{mmol})$, methyl glyoxylate $73-\mathrm{Me}(0.176 \mathrm{~g}, 2.00 \mathrm{mmol})$, bicyclopropylidene (24) $(0.090 \mathrm{~mL}, 1.00 \mathrm{mmol})$, and $\mathrm{NaOAc}$ $(0.164 \mathrm{~g}, 2.00 \mathrm{mmol})$ in $1.10 \mathrm{~mL}$ of ethanol according to $\mathrm{GP} 6\left(80^{\circ} \mathrm{C}, 120 \mathrm{~min}\right)$ gave the product 77d-Me $(0.215 \mathrm{~g}, 78 \%)$ as a light-yellow oil. - IR (film): $\tilde{v}=2954 \mathrm{~cm}^{-1}, 2837,1775$, 1735, 1612, 1514, 1392, 1248. - ${ }^{1} \mathrm{H}$ NMR $\left(250 \mathrm{MHz}, \mathrm{CDCl}_{3}\right): \delta=0.84-0.91(\mathrm{~m}, 1 \mathrm{H}, \mathrm{cPr}-\mathrm{H})$, 1.04-1.30 (m, $3 \mathrm{H}, \mathrm{cPr}-\mathrm{H}), 3.71(\mathrm{~s}, 3 \mathrm{H}), 3.80(\mathrm{~s}, 3 \mathrm{H}), 3.99(\mathrm{~s}, 1 \mathrm{H}), 4.14-4.20(\mathrm{~d}$, $\left.{ }^{2} J_{\mathrm{H}, \mathrm{H}}=15.0 \mathrm{~Hz}, 1 \mathrm{H}, \mathrm{NCH}_{2}\right), 4.82-4.88\left(\mathrm{~d},{ }^{2} J_{\mathrm{H}, \mathrm{H}}=15.0 \mathrm{~Hz}, 1 \mathrm{H}, \mathrm{NCH}_{2}\right), 6.84-6.90(\mathrm{~m}, 2 \mathrm{H}$, $\mathrm{Ar}-\mathrm{H}), 7.15-7.21(\mathrm{~m}, 2 \mathrm{H}, \mathrm{Ar}-\mathrm{H}) .-{ }^{13} \mathrm{C} \mathrm{NMR}\left(62.9 \mathrm{MHz}, \mathrm{CDCl}_{3}\right.$, additional DEPT): $\delta=6.6$ (-, $\left.\mathrm{CH}_{2}, \mathrm{cPr}-\mathrm{C}\right), 8.0\left(-, \mathrm{CH}_{2}, \mathrm{cPr}-\mathrm{C}\right), 37.1$ (-, $\left.\mathrm{C}_{\text {quat }}, \mathrm{C}-3\right), 45.1\left(-, \mathrm{NCH}_{2}\right), 52.2(+, \mathrm{CH}), 55.3$ $\left(+, \mathrm{CH}_{3}, *\right), 57.3\left(+, \mathrm{CH}_{3}, *\right), 114.1(+, 2 \mathrm{CH}, \mathrm{Ar}-\mathrm{C}), 127.2\left(-, \mathrm{C}_{\text {quat }}, \mathrm{Ar}-\mathrm{C}\right), 129.8(+, 2 \mathrm{CH}$, $\operatorname{Ar}-\mathrm{C}), 159.2$ (-, $\left.\mathrm{C}_{\text {quat }}, \operatorname{Ar}-\mathrm{C}\right), 170.2\left(\mathrm{C}_{\text {quat }}, \mathrm{C}=\mathrm{O},{ }^{*}\right), 170.9\left(\mathrm{C}_{\text {quat }}, \mathrm{C}=\mathrm{O}, *\right) .-\mathrm{MS}(\mathrm{EI}): m / z$ $(\%)=275$ (4), 243 (5), 215 (5), 188 (25), 148 (10), 121 (100), 78 (15). - $\mathrm{C}_{15} \mathrm{H}_{17} \mathrm{NO}_{4}$ (275.30): calcd. C 65.44, H 6.22, N 5.09; found C 65.17, H 6.20, N 4.91. 
One-pot three-component applied on methyl hydroxylamine $65 \mathrm{~g} \cdot \mathrm{HCl}$. General Procedure 7

(GP 7): A solution of the methyl hydroxylamine salt (2 equiv.), the aldehyde (2 equiv.), bicyclopropylidene (24) (1 equiv.), and NaOAc (2 equiv.) in ethanol was sealed in a screwcapped vial for the microwave apparatus and heated at the indicated temperature for the indicated time. After cooling down to room temperature, the solution was concentrated under reduced pressure. Equal amounts of water and ethyl acetate were added, and the two phases were separated. The water phase was made basic with a satd. solution of $\mathrm{NaHCO}_{3}$ and extracted three times with ethyl acetate. The combined organic layers were then washed with brine and dried over $\mathrm{Na}_{2} \mathrm{SO}_{4}$.

Reaction with formaldehyde 66-H: Column chromatography ( $25 \mathrm{~g}$ of silica gel, $15 \times 2 \mathrm{~cm}$ column, hexane $\left./ \mathrm{Et}_{2} \mathrm{O} 2: 1\right)$ of the residue obtained from hydroxylamine $\mathbf{6 5 g} \cdot \mathbf{H C l}(0.251 \mathrm{~g}$, $3.00 \mathrm{mmol})$, formaldehyde $66-\mathrm{H}$ solution $(8.0 \mathrm{M})$ in water $(0.375 \mathrm{~mL}, 3.00 \mathrm{mmol})$, bicyclopropylidene (24) $(0.140 \mathrm{~mL}, 0.120 \mathrm{~g}, 1.50 \mathrm{mmol})$, and $\mathrm{NaOAc}(0.246 \mathrm{~g}, 3.00 \mathrm{mmol})$ in $1.75 \mathrm{~mL}$ of ethanol according to $\mathrm{GP} 7\left(80^{\circ} \mathrm{C}, 30 \mathrm{~min}\right)$ gave the product $\mathbf{5 3 g}-\mathrm{H}$ in trace.

Reaction with ethyl glyoxylate 73-Et: Column chromatography (40 g of silica gel, $12 \times 2.5$ $\mathrm{cm}$ column, hexane $\left./ \mathrm{Et}_{2} \mathrm{O} 3: 1\right)$ of the residue obtained from hydroxylamine $\mathbf{6 5} \cdot \mathbf{H C l}(0.251 \mathrm{~g}$, $3.00 \mathrm{mmol})$, ethyl glyoxylate (73-Et) as a solution in toluene $(50 \%$ weight $)(0.60 \mathrm{~mL}$, $3.00 \mathrm{mmol})$, bicyclopropylidene $(\mathbf{2 4})(0.140 \mathrm{~mL}, 0.120 \mathrm{~g}, 1.50 \mathrm{mmol})$, and $\mathrm{NaOAc}(0.246 \mathrm{~g}$, $3.00 \mathrm{mmol})$ in $0.70 \mathrm{~mL}$ of ethanol according to $\mathrm{GP} 7\left(100^{\circ} \mathrm{C}, 70 \mathrm{~min}\right)$ gave no product.

One-pot protocol applied to hydroxylamine $65 \mathrm{c} \cdot \mathrm{HCl}$ and meta-nitrobenzaldehyde 75.8 Benzyl-9-(3-nitrophenyl)-7-oxa-8-azadispiro[2.0.2.3]nonane (81): A solution of $65 \mathrm{c} \cdot \mathrm{HCl}$ (479 mg, $3.00 \mathrm{mmol}$ ), meta-nitrobenzaldehyde (75) (453 mg, $3.00 \mathrm{mmol}$ ), bicyclopropylidene (24) $(0.14 \mathrm{~mL}, 120 \mathrm{mg}, 1.5 \mathrm{mmol})$ and $\mathrm{NaOAc}(246 \mathrm{mg}, 2.00 \mathrm{mmol})$ in ethanol $(0.6 \mathrm{~mL})$, was sealed in a screw capped vial for the microwave oven and heated at $80{ }^{\circ} \mathrm{C}$ for 165 min. After cooling to room temperature, the solution was concentrated under reduced pressure. Equal amounts of water and ethyl acetate $(30 \mathrm{~mL})$ were added, and the two phases were separated. The water phase was made basic with $\mathrm{NaHCO}_{3}$ (satd. solution) and extracted with ethyl acetate $(3 \times 30 \mathrm{~mL})$. The combined organic layers were then washed with brine and 
dried over $\mathrm{Na}_{2} \mathrm{SO}_{4}$. The crude product was purified by column chromatography $(50 \mathrm{~g}$ of flash silica gel, $3 \times 12 \mathrm{~cm}$ column, hexane/ $\left.\mathrm{Et}_{2} \mathrm{O} 3: 1\right)$ to give $81(0.351 \mathrm{~g}, 69 \%)$.

- IR (KBr): $\tilde{v}=3075 \mathrm{~cm}^{-1}, 3006,2997,1531,1526,1353,737 .{ }^{1} \mathrm{H}$ NMR $(250 \mathrm{MHz}$,

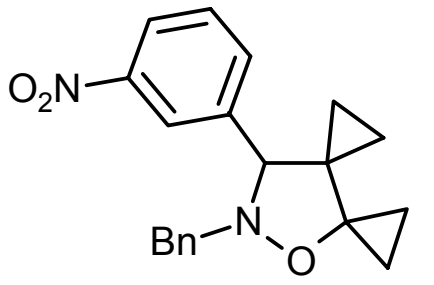
$\left.\mathrm{CDCl}_{3}\right): \delta=0.10-0.24(\mathrm{~m}, 2 \mathrm{H}, \mathrm{cPr}-\mathrm{H}), 0.38-0.52(\mathrm{~m}, 2 \mathrm{H}, \mathrm{cPr}-\mathrm{H})$, 0.61-0.69 (m, 2 H, cPr-H), 0.98-1.02 (m, 2 H, cPr-H), 4.11 (d, $\left.{ }^{2} J_{\mathrm{H}, \mathrm{H}}=12.5 \mathrm{~Hz}, 1 \mathrm{H}, \mathrm{CH}_{2}\right), 4.19(\mathrm{~s}, 1 \mathrm{H}, \mathrm{CH}), 4.28$ (d, $\left.{ }^{2} J_{\mathrm{H}, \mathrm{H}}=12.5 \mathrm{~Hz}, 1 \mathrm{H}, \mathrm{CH}_{2}\right), 7.20-7.33(\mathrm{~m}, 5 \mathrm{H}, \mathrm{Ar}-\mathrm{H}), 7.44-7.51$ (m, $1 \mathrm{H}, \mathrm{Ar}-\mathrm{H}), 7.73-7.82$ (m, $1 \mathrm{H}, \mathrm{Ar}-\mathrm{H}), 8.10-8.17$ (m, $2 \mathrm{H}, \mathrm{Ar}-\mathrm{H})$. $-{ }^{13} \mathrm{C}$ NMR $\left(62.9 \mathrm{MHz}, \mathrm{CDCl}_{3}\right.$, additional DEPT): $\delta=6.6\left(-, \mathrm{CH}_{2}, \mathrm{cPr}-\mathrm{C}\right), 7.3\left(-, \mathrm{CH}_{2}, \mathrm{cPr}-\right.$ C), 8.8 (-, $\left.\mathrm{CH}_{2}, \mathrm{cPr}-\mathrm{C}\right), 9.3$ (-, $\left.\mathrm{CH}_{2}, \mathrm{cPr}-\mathrm{C}\right), 33.1$ ( $\left.\mathrm{C}_{\text {quat }}, \mathrm{C}-3\right), 62.0\left(-, \mathrm{CH}_{2}\right), 75.5\left(\mathrm{C}_{\text {quat }}, \mathrm{C}-6\right)$, $76.6(+, \mathrm{CH}), 122.7(+, \mathrm{CH}, \mathrm{Ar}-\mathrm{C}), 123.4(+, \mathrm{CH}, \mathrm{Ar}-\mathrm{C}), 127.4(+, \mathrm{CH}, \mathrm{Ar}-\mathrm{C}), 128.3(+, 2$ $\mathrm{CH}, \mathrm{Ar}-\mathrm{C}), 129.0$ (+, $2 \mathrm{CH}, \mathrm{Ar}-\mathrm{C}), 129.2$ (+, CH, Ar-C), 134.7 (+, CH, Ar-C), $136.4\left(\mathrm{C}_{\text {quat }}\right.$, Ar-C), 141.4 ( $\left.\mathrm{C}_{\text {quat }}, \mathrm{Ar}-\mathrm{C}\right), 148.1$ (C $\left.\mathrm{C}_{\text {quat }}, \mathrm{Ar}-\mathrm{C}\right) . \mathrm{MS}(\mathrm{EI}): m / z(\%)=336$ (5), 307 (2), 214 (8), 180 (10), 128 (30), 105 (20), 91 (100). $-\mathrm{C}_{20} \mathrm{H}_{20} \mathrm{~N}_{2} \mathrm{O}_{3}$ (336.38): calcd. C 71.41, H 5.99, N 8.33; found C 71.32, H 6.04, N 8.15.

One-pot protocol applied to hydroxylamine $65 \mathrm{c} \cdot \mathrm{HCl}$ and meta-nitrobenzaldehyde (75):

A solution of $\mathbf{6 5 c} \cdot \mathbf{H C l} \quad(479 \mathrm{mg}, 3.00 \mathrm{mmol})$, meta-nitrobenzaldehyde 75 (453 $\mathrm{mg}$, $3.00 \mathrm{mmol})$, bicyclopropylidene (24) $(0.14 \mathrm{~mL}, 120 \mathrm{mg}, 1.5 \mathrm{mmol})$ and $\mathrm{NaOAc}$ (246 mg, $2 \mathrm{mmol})$ in ethanol $(0.6 \mathrm{~mL})$, was sealed in a screw capped vial for the microwave oven and heated at $100{ }^{\circ} \mathrm{C}$ for $240 \mathrm{~min}$. After cooling to room temperature, the solution was concentrated under reduced pressure. Equal amount of water and ethyl acetate $(30 \mathrm{~mL})$ were added, and the two phases were separated. The water phase was made basic with $\mathrm{NaHCO}_{3}$ (satd. solution) and extracted with ethyl acetate $(3 \times 30 \mathrm{~mL})$. The combined organic layers were then washed with brine and dried over $\mathrm{Na}_{2} \mathrm{SO}_{4}$. The crude product was purified by column chromatography (50 g of flash silica gel, $3 \times 12 \mathrm{~cm}$ column, hexane/ $\mathrm{Et}_{2} \mathrm{O} 3: 1$ ) to give $81\left(R_{\mathrm{f}}=0.37,0.135 \mathrm{~g}, 27 \%\right)$ and 5-(Benzyl)-4-(3-nitrophenyl)-5-azaspiro[2.5]octan-8one $(85)\left(R_{\mathrm{f}}=0.20,0.201 \mathrm{~g}, 40 \%\right)$. 
(85): - IR (film): $\tilde{v}=3086 \mathrm{~cm}^{-1}, 2822,1698,1530,1350,1143,1099 .-{ }^{1} \mathrm{H}$ NMR $(250 \mathrm{MHz}$, $\left.\mathrm{CDCl}_{3}\right): \delta=0.32-0.37(\mathrm{~m}, 1 \mathrm{H}, \mathrm{cPr}-\mathrm{H}), 0.92-0.97(\mathrm{~m}, 1 \mathrm{H}, \mathrm{cPr}-\mathrm{H})$,<smiles>O=C1CCN(Cc2ccccc2)C(c2cccc([N+](=O)[O-])c2)C12CC2</smiles>
1.20-1.27 (m, $1 \mathrm{H}, \mathrm{cPr}-\mathrm{H}), 1.56-1.62(\mathrm{~m}, 1 \mathrm{H}, \mathrm{cPr}-\mathrm{H}), 2.46-2.55$ (m, $\left.1 \mathrm{H}, \mathrm{CH}_{2}-\mathrm{CH}_{2}\right), 2.70-2.73\left(\mathrm{~m}, 1 \mathrm{H}, \mathrm{CH}_{2}-\mathrm{CH}_{2}\right), 2.91-3.02(\mathrm{~m}, 2$ $\left.\mathrm{H}, \mathrm{CH}_{2}-\mathrm{CH}_{2}\right), 3.64-3.69\left(\mathrm{~d},{ }^{2} \mathrm{~J}_{\mathrm{H}, \mathrm{H}}=13.5 \mathrm{~Hz}, 1 \mathrm{H}, \mathrm{NCH}_{2} \mathrm{Ph}\right), 3.72(\mathrm{~s}$, $1 \mathrm{H}, \mathrm{CH}), 3.85-3.90\left(\mathrm{~d},{ }^{2} J_{\mathrm{H}, \mathrm{H}}=13.5 \mathrm{~Hz}, 1 \mathrm{H}, \mathrm{NCH}_{2} \mathrm{Ph}\right), 7.29-7.68$ (m, $7 \mathrm{H}, \mathrm{Ar}-\mathrm{H}), 8.14-8.15$ (m, $2 \mathrm{H}, \mathrm{Ar}-\mathrm{H}) .-{ }^{13} \mathrm{C} \mathrm{NMR}\left(62.9 \mathrm{MHz}, \mathrm{CDCl}_{3}\right.$, additional APT): $\delta=12.4\left(-, \mathrm{CH}_{2}, \mathrm{cPr}-\mathrm{C}\right), 21.0\left(-, \mathrm{CH}_{2}, \mathrm{cPr}-\mathrm{C}\right), 30.7\left(-,^{*}\right), 37.6\left(-,{ }^{*}\right), 45.4\left(-,{ }^{*}\right), 58.5\left(-,{ }^{*}\right)$, $68.4(+, \mathrm{CH}), 122.5(+, \mathrm{CH}, \mathrm{Ar}-\mathrm{C}), 123.8$ (+, CH, Ar-C), 127.5 (+, CH, Ar-C), $128.6(+, 2$ $\mathrm{CH}, \mathrm{Ar}-\mathrm{C}), 128.6(+, 2 \mathrm{CH}, \mathrm{Ar}-\mathrm{C}), 129.1$ (+, CH, Ar-C), $134.6(+, \mathrm{CH}, \mathrm{Ar}-\mathrm{C}), 138.1\left(\mathrm{C}_{\text {quat }}\right.$, Ar-C), 142.2 ( $\left.\mathrm{C}_{\text {quat }}, \mathrm{Ar}-\mathrm{C}\right), 148.1$ ( $\left.\mathrm{C}_{\text {quat }}, \mathrm{Ar}-\mathrm{C}\right), 208.3\left(\mathrm{C}_{\text {quat }}, \mathrm{C}=\mathrm{O}\right) .-\mathrm{MS}(\mathrm{EI}): m / z(\%)=336$ (20), 245 (15), 230 (5), 218 (15), 214 (80), 150 (40), 105 (10), 91 (100), 77 (20). HRMS (EI) calcd. for $\mathrm{C}_{20} \mathrm{H}_{20} \mathrm{~N}_{2} \mathrm{O}_{3} 337.1547\left[\mathrm{M}+\mathrm{H}^{+}\right]$, found 337.1548.

One-pot three-component synthesis of $\beta$-lactams 77c-cHex and 53e, applied at the free hydroxylamine. General Procedure 8

(GP 8): A solution of the hydroxylamine (1.7 equiv.), the aldehyde (1.7 equiv.), bicyclopropylidene (24) (1 equiv.), and TFA (1 equiv.) in $o$-xylene was sealed in a screw-capped vial for the microwave apparatus and heated at $110{ }^{\circ} \mathrm{C}$ for the indicated time. After cooling down to room temperature, the reaction mixture was filtered through a short pad of silica gel, eluting initially with pentane, to remove the high boiling-solvent, then with methanol to recover the mixture. The solvent was evaporated and the crude was purified by column cromatography.

Cyclohexyl 5-benzyl-6-oxo-5-azaspiro[2.3]hexane-4-carboxylate (77c-cHex): Column<smiles>O=C(OC1CCCCC1)C1N(Cc2ccccc2)C(=O)C12CC2</smiles>
chromatography $\left(R_{\mathrm{f}}=0.21,35 \mathrm{~g}\right.$ of flash silica gel, $14 \times 2.5 \mathrm{~cm}$ column, hexane/ $\mathrm{Et}_{2} \mathrm{O} 3: 2$ ) of the residue obtained from 65c·HCl $(0.304 \mathrm{~g}, \quad 2.50 \mathrm{mmol}), \quad$ cyclohexyl glyoxylate $\mathbf{7 3 -}$ cHex $(0.390 \mathrm{~g}, 2.50 \mathrm{mmol})$, bicyclopropylidene (24) $(0.140 \mathrm{~mL}$, $0.120 \mathrm{~g}, 1.50 \mathrm{mmol})$, and TFA $(0.11 \mathrm{~mL}, 1.50 \mathrm{mmol})$ in $o$-xylene $(1.50 \mathrm{~mL})$ according to $\mathrm{GP} 8\left(110{ }^{\circ} \mathrm{C}, 60 \mathrm{~min}\right)$ gave the product $77 \mathbf{c}-\mathbf{c H e x}(0.141 \mathrm{~g}, 30 \%)$ as a light-yellow oil. - IR (film): $\tilde{v}=3063 \mathrm{~cm}^{-1}, 2936,2858,1771,1455,1393,1353,1201,1013$. 
$-{ }^{1} \mathrm{H}$ NMR $\left(250 \mathrm{MHz}, \mathrm{CDCl}_{3}\right): \delta=0.82-0.95(\mathrm{~m}, 1 \mathrm{H}, \mathrm{cPr}-\mathrm{H}), 1.07-1.42(\mathrm{~m}, 9 \mathrm{H}, \mathrm{cPr}-\mathrm{H}$, cHex-H), 1.71-1.83 (m, $4 \mathrm{H}, \mathrm{cHex}-\mathrm{H}), 3.97(\mathrm{~s}, 1 \mathrm{H}), 4.19-4.25\left(\mathrm{~d},{ }^{2} J_{\mathrm{H}, \mathrm{H}}=15.0 \mathrm{~Hz}, 1 \mathrm{H}\right.$, $\left.\mathrm{NCH}_{2} \mathrm{Ph}\right), 4.73-4.95(\mathrm{~m}, 1 \mathrm{H}, \mathrm{OCH}, \mathrm{cHex}-\mathrm{H}), 4.89-4.95\left(\mathrm{~d},{ }^{2} J_{\mathrm{H}, \mathrm{H}}=15.0 \mathrm{~Hz}, 1 \mathrm{H}, \mathrm{NCH}_{2} \mathrm{Ph}\right)$, 7.24-7.39 (m, $5 \mathrm{H}, \mathrm{Ar}-\mathrm{H}) .-{ }^{13} \mathrm{C} \mathrm{NMR}\left(62.9 \mathrm{MHz}, \mathrm{CDCl}_{3}\right.$, additional APT): $\delta=6.36\left(-, \mathrm{CH}_{2}\right.$, cPr-C), 7.93 (-, $\left.\mathrm{CH}_{2}, \mathrm{cPr}-\mathrm{C}\right), 23.6\left(-, \mathrm{CH}_{2}, *\right), 23.6\left(-,{ }^{*}\right), 25.1\left(-,{ }^{*}\right), 31.5\left(-,{ }^{*}\right), 31.7\left(-,{ }^{*}\right)$, $37.1(-, *), 45.6(-, *), 57.5(+, \mathrm{CH}), 74.0(+, \mathrm{OCH}), 127.8(+, \mathrm{CH}, \mathrm{Ar}-\mathrm{C}), 128.4(+, 2 \mathrm{CH}$, Ar-C), 128.8 (+, 2 CH, Ar-C), 135.3 (-, $\left.\mathrm{C}_{\text {quat }}, \mathrm{Ar}-\mathrm{C}\right), 169.1$ (-, $\left.\mathrm{C}_{\text {quat }}, \mathrm{Ar}-\mathrm{C}\right), 171.2(-, \mathrm{C}=\mathrm{O}) .-$ MS (EI): $m / z(\%)=285$ (1), 186 (30), 158 (25), 91 (100), 55 (35), 41 (22). - MS (DCI): $m / z$ $(\%)=644(10)\left[2 \mathrm{M}+\mathrm{NH}_{4}^{+}\right], 627(5)\left[2 \mathrm{M}+\mathrm{H}^{+}\right], 331(100)\left[\mathrm{M}+\mathrm{NH}_{4}^{+}\right], 314(40)\left[\mathrm{M}+\mathrm{H}^{+}\right]$. $-\mathrm{C}_{19} \mathrm{H}_{23} \mathrm{NO}_{3}$ (313.39): calcd. C 72.82, H 7.40, N 4.47; found C 72.63, H 7.44, N 4.31.

5-Benzyl-6-(2-iodophenyl)-5-azaspiro[2.3]hexane-4-one (53e): Column chromatography $\left(R_{\mathrm{f}}=0.26,35 \mathrm{~g}\right.$ of silica gel, $2.5 \times 12 \mathrm{~cm}$ column, hexane/ $\left.\mathrm{Et}_{2} \mathrm{O} 2: 1\right)$ of the residue obtained from 65c·HCl $(0.346 \mathrm{~g}, 2.80 \mathrm{mmol}), o$-iodobenzaldehyde (76) $(0.650 \mathrm{~g}, 2.80 \mathrm{mmol})$, bicyclopropylidene (24) $(0.150 \mathrm{~mL}, 0.120 \mathrm{~g}, 1.60 \mathrm{mmol})$, and TFA $(0.12 \mathrm{~mL}, 0.182 \mathrm{~g}, 1.60 \mathrm{mmol})$ in $o$-xylene $(1.60 \mathrm{~mL})$ according to $\mathrm{GP} 8\left(110^{\circ} \mathrm{C}, 120 \mathrm{~min}\right)$ gave the product $(0.112 \mathrm{~g}, 18 \%)$ as colorless oil.

One-pot protocol applied to hydroxylamine $65 \mathrm{c} \cdot \mathrm{HCl}$ and formaldehyde $(66-\mathrm{H})$ with Methylenecyclopropane (43) as dipolarophile: A solution of $65 \mathrm{c} \cdot \mathrm{HCl}(0.479 \mathrm{~g}, 3.00 \mathrm{mmol})$, formaldehyde $(66-\mathrm{H})$ solution $(8 \mathrm{M})$ in water $(0.375 \mathrm{~mL}, 3.00 \mathrm{mmol})$, methylenecyclopropane (43) $(0.1 \mathrm{~mL}, 81 \mathrm{mg}, 1.5 \mathrm{mmol})$ and NaOAc $(0.246 \mathrm{~g}, 3.0 \mathrm{mmol})$ in ethanol $(1.0 \mathrm{~mL})$, was sealed in a screw-capped vial for the microwave oven, and heated at $80^{\circ} \mathrm{C}$ for $70 \mathrm{~min}$. After cooling to room temperature, the solution was concentrated under reduced pressure. An equal amount each of water and ethyl acetate $(30 \mathrm{~mL})$ was added, and the two phases were separated. The water phase was made basic with $\mathrm{NaHCO}_{3}$ (satd. solution) and extracted with ethyl acetate $(3 \times 30 \mathrm{~mL})$. The combined organic layers were then washed with brine $(2 \times 30$ $\mathrm{mL}$ ) and dried over $\mathrm{Na}_{2} \mathrm{SO}_{4}$. After filtration and evaporation of the solvent a crude mixture was obtained, containing 1-benzylazetidin-2-one $\left(86, \mathrm{R}^{1}=\mathrm{Bn} ; \mathrm{R}^{2}=\mathrm{H}\right)$ and 6-benzyl-5-oxa-6azaspiro[2.4] heptane (87). Column chromatography (35 g of silica gel, $15 \times 2.5 \mathrm{~cm}$ column, hexane/ $\left.\mathrm{Et}_{2} \mathrm{O} 3: 1\right)$ of the residue gave $87\left(0.234 \mathrm{~g}, 82 \%, R_{\mathrm{f}}=0.28\right)$. A second column 
chromatography (12 g of silica gel, $8 \times 2 \mathrm{~cm}$, column, hexane/ $\operatorname{Et}_{2} \mathrm{O} 2: 1$ ) was necessary to separate $86\left(21 \mathrm{mg}, 9 \%, R_{\mathrm{f}}=0.12\right)$ from benzylhydroxylamine

6-benzyl-5-oxa-6-azaspiro[2.4]heptane (87): - IR (film): $\tilde{v}=3087 \mathrm{~cm}^{-1}, 3068,2997,2867$, 1496, 1454, 1030, 1018. - ${ }^{1} \mathrm{H}$ NMR $\left(300 \mathrm{MHz}, \mathrm{C}_{2} \mathrm{D}_{2} \mathrm{Cl}_{4}, 100{ }^{\circ} \mathrm{C}\right)$ :<smiles>c1ccc(CN2CC3(CC3)CO2)cc1</smiles>
$\delta=0.73-0.81(\mathrm{~m}, 4 \mathrm{H}, \mathrm{cPr}-\mathrm{H}), 2.97(\mathrm{~s}, 2 \mathrm{H}), 3.88(\mathrm{~s}, 2 \mathrm{H}), 4.09(\mathrm{~s}, 2$ $\mathrm{H}), 7.28-7.43(\mathrm{~m}, 5 \mathrm{H}, \mathrm{Ar}-\mathrm{H}) .-{ }^{13} \mathrm{C} \mathrm{NMR}\left(75.5 \mathrm{MHz}, \mathrm{C}_{2} \mathrm{D}_{2} \mathrm{Cl}_{4}\right.$, $\left.100{ }^{\circ} \mathrm{C}\right): \delta=10.2\left(2 \mathrm{CH}_{2}, \mathrm{cPr}-\mathrm{C}\right), 24.8\left(\mathrm{C}_{\text {quat }}, \mathrm{C}-3\right), 61.8\left(\mathrm{CH}_{2}, *\right)$, $62.2\left(\mathrm{CH}_{2}, *\right), 72.9\left(\mathrm{CH}_{2}, *\right), 126.9(\mathrm{CH}, \mathrm{Ar}-\mathrm{C}), 128.0$ (2 CH, Ar-C), 128.8 (2 CH, Ar-C), $137.4\left(\mathrm{C}_{\text {quat }}, \mathrm{Ar}-\mathrm{C}\right) .-\mathrm{MS}(\mathrm{EI}): m / z(\%)=190(2)\left[\mathrm{M}+\mathrm{H}^{+}\right], 189$ (12), 161 (2), 106 (4), 91 (100), 77 (5). $-\mathrm{C}_{12} \mathrm{H}_{15} \mathrm{NO}$ (189.25): calcd; C 76.16, H 7.99, N 7.40; found C 76.18, H 7.72, N 7.22 . 


\subsection{Synthesis of Compounds in Chapter 3}

8-(p-Methoxybenzyl)-7-oxa-8-azadispiro[2.0.2.3]nonane (47g): A solution of the nitrone 44g (0.166 mg, $1.00 \mathrm{mmol})$, bicyclopropylidene (24) (0.19 mL, $0.160 \mathrm{~g}, 2.00 \mathrm{mmol})$, in tetrachloroethane $(2 \mathrm{~mL})$ was sealed in a screw-capped vial and heated at $80{ }^{\circ} \mathrm{C}$ for 30 minutes under microwaves irradiation. After cooling down to room temperature, the solution was concentrated under reduced pressure. After column cromatography $\left(R_{\mathrm{f}}=0.27\right.$, $25 \mathrm{~g}$ of silica gel, $2 \times 15 \mathrm{~cm}$ column, hexane/ $\left.\mathrm{Et}_{2} \mathrm{O} 2: 1\right) 47 \mathrm{~g}$ was obtained (120.0 $\mathrm{mg}, 49 \%$ ).

5-(4-Methoxybenzyl)-5-azaspiro[2.5]octan-8-one (49g): A solution of the nitrone $44 \mathrm{~g}(0.130 \mathrm{mg}, 0.79 \mathrm{mmol})$, bicyclopropylidene $(\mathbf{2 4})(0.15 \mathrm{~mL}, 0.126 \mathrm{~g}, 1.57 \mathrm{mmol})$, in $o$ xylene $(1.00 \mathrm{~mL})$ was sealed in a screw-capped vial and heated at $130{ }^{\circ} \mathrm{C}$ for 15 minutes under microwaves irradiation. After cooling down to room temperature the reaction mixture was filtered through a short pad of silica gel, eluting initially with pentane, to remove the high boiling-solvent, then with methanol to recover the mixture. The solvent was evaporated and the crude was purified by column cromatography $\left(R_{\mathrm{f}}=0.17,25 \mathrm{~g}\right.$ of silica gel, $2 \times 15 \mathrm{~cm}$ column, hexane/Et $\left.{ }_{2} \mathrm{O} 1: 1\right)$ to give $49 \mathrm{~g}(57.0 \mathrm{mg}, 29 \%)$ as a yellow oil.

49g: - IR (KBr): $\tilde{v}=3000 \mathrm{~cm}^{-1}, 2952,2904,2806,2756,1688,1606,1511 .-{ }^{1} \mathrm{H}$ NMR

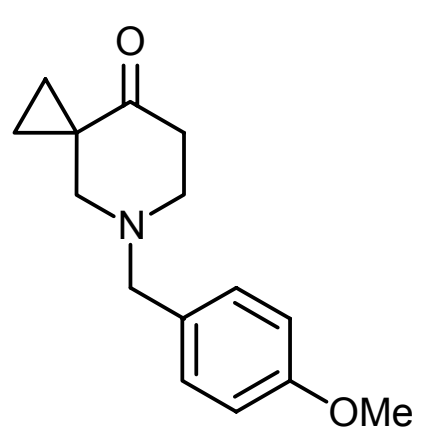

$\left(250 \mathrm{MHz}, \mathrm{CDCl}_{3}\right): \delta=0.60-0.70(\mathrm{~m}, 2 \mathrm{H}, \mathrm{cPr}-\mathrm{H}), 1.23-1.28(\mathrm{~m}$, $2 \mathrm{H}, \mathrm{cPr}-\mathrm{H}), 2.50-2.55\left(\mathrm{~m}, 4 \mathrm{H}, \mathrm{CH}_{2}-\mathrm{CH}_{2}\right), 2.82-2.87(\mathrm{~m}, 2 \mathrm{H}$, $\mathrm{NCH}_{2}$ ), 3.54 (s, $\left.2 \mathrm{H}, \mathrm{NCH}_{2} \mathrm{Ph}\right), 3.79$ (s, $\left.3 \mathrm{H}, \mathrm{CH}_{3}\right), 6.83-6.88$ (m, 2 $\mathrm{H}, \mathrm{Ar}-\mathrm{H}), 7.24-7.27$ (m, $2 \mathrm{H}, \mathrm{Ar}-\mathrm{H}) .-{ }^{13} \mathrm{C}$ NMR $(62.9 \mathrm{MHz}$, $\mathrm{CDCl}_{3}$, additional DEPT): $\delta=17.6\left(-, 2 \mathrm{CH}_{2}, \mathrm{cPr}-\mathrm{C}\right), 28.4\left(\mathrm{C}_{\text {quat }}\right.$, C-3), $39.3\left(-, \mathrm{CH}_{2}, *\right), 52.0\left(-, \mathrm{CH}_{2}, *\right), 55.2\left(+, \mathrm{CH}_{3}\right), 59.8(-$, $\left.\mathrm{CH}_{2}, *\right), 61.5\left(-, \mathrm{CH}_{2}, *\right), 113.6(+, 2 \mathrm{CH}, \mathrm{Ar}-\mathrm{C}), 129.9$ ( $\left.\mathrm{C}_{\text {quat }}, \mathrm{Ar}-\mathrm{C}\right), 130.0$ (+, $\left.2 \mathrm{CH}, \mathrm{Ar}-\mathrm{C}\right)$, $158.8\left(\mathrm{C}_{\text {quat }}, \mathrm{Ar}-\mathrm{C}\right), 176.5\left(\mathrm{C}_{\text {quat }}, \mathrm{C}=\mathrm{O}\right) .-\mathrm{MS}(\mathrm{EI}): m / z(\%)=245$ (25), 124 (10), 121 (100), 91 (5), 77 (5). - $\mathrm{C}_{15} \mathrm{H}_{19} \mathrm{NO}_{2}$ (245.32): calcd. C 73.44, H 7.81, N 5.71; found C 73.12, H 7.72, N 5.65 . 


\section{Reaction of Bicyclopropylidene with In situ Generated Nitrones under Microwave Heating}

8-(p-Methoxybenzyl)-7-oxa-8-aza-dispiro[2.0.2.3]nonane (47g): A solution of the free hydroxylamine 65d $(0.613 \mathrm{mg}, 4.00 \mathrm{mmol})$, bicyclopropylidene (24) (0.19 mL, $0.160 \mathrm{~g}$, $2.00 \mathrm{mmol})$, formaldehyde $66-\mathrm{H}$ as a solution $(8 \mathrm{M})$ in water $(0.50 \mathrm{~mL}, 4.00 \mathrm{mmol})$ in $o-$ xylene $(1.75 \mathrm{~mL})$ was sealed in a screw-capped vial and heated at $100{ }^{\circ} \mathrm{C}$ for 15 minutes. After cooling down to room temperature, the reaction mixture was filtered through a short pad of silica gel, eluting initially with pentane, to remove the high boiling-solvent, then with methanol to recover the mixture. The solvent was evaporated in vacuo and the crude was purified by column cromatography cromatography $\left(R_{\mathrm{f}}=0.27,42 \mathrm{~g}\right.$ of silica gel, $3 \times 15 \mathrm{~cm}$ column, hexane/Et $\left.{ }_{2} \mathrm{O} 2: 1\right)$ to give $\mathbf{4 7 g}(243.0 \mathrm{mg}, 49 \%)$.

5-(p-Methoxybenzyl)-5-azaspiro[2.5]octan-8-one (49g): A solution of the free hydroxylamine 65d $(0.298 \mathrm{mg}, 0.080 \mathrm{~g}, 1.94 \mathrm{mmol})$, bicyclopropylidene (24) $(0.090 \mathrm{~mL}$, $1.00 \mathrm{mmol})$, and formaldehyde $66-\mathrm{H}$ as a solution $(8 \mathrm{M})$ in water $(0.125 \mathrm{~mL}, 1.00 \mathrm{mmol})$ in $o$-xylene $(1.00 \mathrm{~mL})$ was sealed in a screw-capped vial and heated at $130{ }^{\circ} \mathrm{C}$ for 15 minutes. After cooling down to room temperature the reaction mixture was filtered through a short pad of silica gel, eluting initially with pentane, to remove the high boiling-solvent, then with methanol to recover the mixture. The solvent was evaporated and the crude was purified by column cromatography $\left(R_{\mathrm{f}}=0.17,25 \mathrm{~g}\right.$ of silica gel, $15 \times 2 \mathrm{~cm}$ column, hexane $\left./ \mathrm{Et}_{2} \mathrm{O} 1: 1\right)$ to give $49 \mathrm{~g}(90.0 \mathrm{mg}, 37 \%)$.

\section{8-Benzyl-7-oxa-8-azadispiro[2.0.2.3]nonane (47j) and 5-benzyl-5-azaspiro[2.5]octan-8-} one (49j): A solution of the benzyl hydroxylamine $65 \mathrm{c}(0.276 \mathrm{mg}, 2.20 \mathrm{mmol})$, bicyclopropylidene (24) $(0.10 \mathrm{~mL}, 0.080 \mathrm{~g}, 1.00 \mathrm{mmol})$, and formaldehyde $66-\mathrm{H}$ as a solution $(8 \mathrm{M})$ in water $(0.27 \mathrm{~mL}, 2.20 \mathrm{mmol})$ in $o$-xylene $(2.0 \mathrm{~mL})$ was sealed in a screw-capped vial and heated at $100{ }^{\circ} \mathrm{C}$ for 20 minutes. After cooling down to room temperature the solvent was evaporated and the crude product was purified by column cromatography ( $34 \mathrm{~g}$ of silica gel, $12 \times 3 \mathrm{~cm}$ column, hexane $\left./ \mathrm{Et}_{2} \mathrm{O} 2: 1\right)$ to give $47 \mathbf{j}\left(R_{\mathrm{f}}=0.24,0.117 \mathrm{~g}, 54 \%\right)$ and $49 \mathbf{j}\left(R_{\mathrm{f}}=0.16\right.$, $180.0 \mathrm{mg}, 7 \%)$. 
(47j): - IR (film): $\tilde{v}=3064 \mathrm{~cm}^{-1}, 3000,2931,2868,1653,1496,1454,1027 .-{ }^{1} \mathrm{H}$ NMR

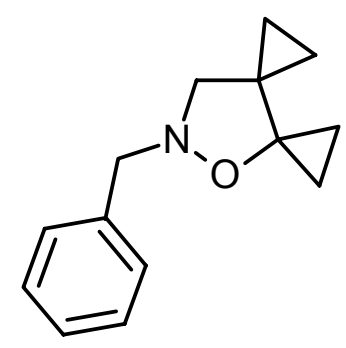

$\left(250 \mathrm{MHz}, \mathrm{CDCl}_{3}\right): \delta=0.23-0.52$ (bs, $\left.4 \mathrm{H}, \mathrm{cPr}-\mathrm{H}\right), 0.67$ (bs, $2 \mathrm{H}, \mathrm{cPr}-$ $\mathrm{H}$ ), 0.87 (bs, $2 \mathrm{H}, \mathrm{cPr}-\mathrm{H}$ ), 3.03 (bs, $1 \mathrm{H}, \mathrm{CH}_{2}$ ), 3.43 (bs, $1 \mathrm{H}, \mathrm{CH}_{2}$ ), 4.02 (bs, $1 \mathrm{H}, \mathrm{CH}_{2}$ ), 4.30 (bs, $1 \mathrm{H}, \mathrm{CH}_{2}$ ), 7.13-7.53 (m, $\left.5 \mathrm{H}, \mathrm{Ar}-\mathrm{H}\right) .-{ }^{1} \mathrm{H}$ $\operatorname{NMR}\left(300 \mathrm{MHz}, \mathrm{C}_{2} \mathrm{D}_{2} \mathrm{Cl}_{4}, 100{ }^{\circ} \mathrm{C}\right): \delta=0.37-0.41(\mathrm{~m}, 2 \mathrm{H}, \mathrm{cPr}-\mathrm{H})$, 0.44-0.48 (m, 2 H, cPr-H) 0.67-0.71 (m, 2 H, cPr-H), 0.85-0.90 (m, 2 $\mathrm{H}, \mathrm{cPr}-\mathrm{H}), 3.25\left(\mathrm{~s}, 2 \mathrm{H}, \mathrm{CH}_{2}\right), 4.19\left(\mathrm{~s}, 2 \mathrm{H}, \mathrm{CH}_{2}\right), 7.25-7.45(\mathrm{~m}, 5 \mathrm{H}, \mathrm{Ar}-\mathrm{H}) .-{ }^{13} \mathrm{C} \mathrm{NMR}$ (75.5 MHz, $\left.\mathrm{C}_{2} \mathrm{D}_{2} \mathrm{Cl}_{4}, 100{ }^{\circ} \mathrm{C}\right): \delta=7.3\left(2 \mathrm{CH}_{2}, \mathrm{cPr}-\mathrm{C}\right), 8.1\left(2 \mathrm{CH}_{2}, \mathrm{cPr}-\mathrm{C}\right), 26.4\left(\mathrm{C}_{\text {quat }}\right), 62.8$ $\left(\mathrm{CH}_{2},{ }^{*}\right), 63.1\left(\mathrm{CH}_{2},{ }^{*}\right), 65.6\left(\mathrm{C}_{\text {quat }}, \mathrm{C}-6\right), 126.9$ (+, $\left.\mathrm{CH}, \mathrm{Ar}-\mathrm{C}\right), 128.0(+, 2 \mathrm{CH}, \mathrm{Ar}-\mathrm{C}), 128.8$ (+, $2 \mathrm{CH}, \mathrm{Ar}-\mathrm{C}), 137.5\left(\mathrm{C}_{\text {quat }}, \mathrm{Ar}-\mathrm{C}\right) .-\mathrm{MS}(\mathrm{EI}): m / z(\%)=216(1)\left[\mathrm{M}+\mathrm{H}^{+}\right], 215$ (5), 187 (2), 186 (10), 158 (10), 105 (40), 91 (100), 77 (10), 65 (22), 54 (25). - HRMS (EI) calcd. for $\mathrm{C}_{14} \mathrm{H}_{17} \mathrm{NO} 216.1383\left[\mathrm{M}+\mathrm{H}^{+}\right]$, found 216.1384 .

(49j): - IR (film): $\tilde{v}=3066 \mathrm{~cm}^{-1}, 2948,2808,1753$ (weak), 1699, 1495, 1454, 1357, 1152,

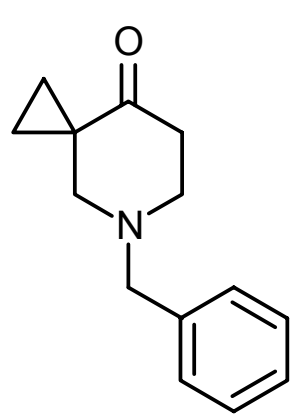
1028. - ${ }^{1} \mathrm{H}$ NMR (250 MHz, $\left.\mathrm{CDCl}_{3}\right): \delta=0.62-0.66(\mathrm{~m}, 2 \mathrm{H}, \mathrm{cPr}-\mathrm{H})$, 1.26-1.30 (m, 2 H, cPr-H), 2.40-2.58 (m, 4 H, $\left.\mathrm{CH}_{2}-\mathrm{CH}_{2}\right), 2.86-2.91$ (m, $\left.2 \mathrm{H}, \mathrm{CH}_{2}\right), 3.62$ (s, $\left.2 \mathrm{H}, \mathrm{NCH}_{2} \mathrm{Ph}\right), 7.26-7.41$ (m, $\left.5 \mathrm{H}, \mathrm{Ar}-\mathrm{H}\right) .-{ }^{13} \mathrm{C} \mathrm{NMR}$ (75.5 MHz, $\mathrm{CDCl}_{3}$, additional DEPT): $\delta=17.6\left(-, 2 \mathrm{CH}_{2}, \mathrm{cPr}-\mathrm{C}\right), 28.5$ $\left(\mathrm{C}_{\text {quat }}, \mathrm{C}-3\right), 39.3\left(-, \mathrm{CH}_{2}\right), 52.2\left(-, \mathrm{NCH}_{2}, *\right), 60.0\left(-, \mathrm{NCH}_{2}, *\right), 62.2(-$,

$\left.\mathrm{NCH}_{2}, *\right), 127.3(+, \mathrm{CH}, \mathrm{Ar}-\mathrm{C}), 128.4(+, 2 \mathrm{CH}, \mathrm{Ar}-\mathrm{C}), 128.8(+, 2 \mathrm{CH}$, $\operatorname{Ar}-\mathrm{C}), 138.0\left(\mathrm{C}_{\text {quat }}, \mathrm{Ar}-\mathrm{C}\right), 209.0\left(\mathrm{C}_{\text {quat }}, \mathrm{C}=\mathrm{O}\right) .-\mathrm{MS}(\mathrm{EI}): \mathrm{m} / z(\%)=215(20), 138(10), 124$ (25), 91 (100), 65 (15), 42 (8). - HRMS (EI) calcd. for $\mathrm{C}_{14} \mathrm{H}_{17} \mathrm{NO} 216.1383\left[\mathrm{M}+\mathrm{H}^{+}\right]$, found 216.1384 .

Ethyl 8-benzhydryl-7-oxa-8-azadispiro[2.0.2.3]nonane-9-carboxylate (47e-Et): Column chromatography $\left(R_{\mathrm{f}}=0.33,42 \mathrm{~g}\right.$ of silica gel, $12 \times 3 \mathrm{~cm}$ column, hexane $\left./ \mathrm{Et}_{2} \mathrm{O} 4: 1\right)$ of the residue obtained from $\mathbf{6 5 e} \cdot \mathbf{H C l}(0.550 \mathrm{~g}, 2.33 \mathrm{mmol})$, ethyl glyoxylate $73-\mathbf{E t}$ as a solution (50 \% weight) in toluene $(0.50 \mathrm{~mL}, 2.33 \mathrm{mmol})$, bicyclopropylidene $(\mathbf{2 4})(0.150 \mathrm{~mL}, 0.130 \mathrm{~g}$, $1.63 \mathrm{mmol})$, and $\mathrm{NaOAc}(0.191 \mathrm{~g}, 2.33 \mathrm{mmol})$ in ethanol $(0.6 \mathrm{~mL})$ according to $\mathrm{GP} 6\left(80{ }^{\circ} \mathrm{C}\right.$, $25 \mathrm{~min})$ gave the product $47 \mathrm{e}-\mathbf{E t}(0.351 \mathrm{~g}, 59 \%)$ as a colorless solid. 
(47e-Et): - M.p $=70{ }^{\circ} \mathrm{C} .-\mathrm{IR}(\mathrm{KBr}): \tilde{v}=3066 \mathrm{~cm}^{-1}, 2998,2896,1752,1452,1162 .-{ }^{1} \mathrm{H}$<smiles>CCOC(=O)C1N(Cc2ccccc2)OC2(CC2)C12CC2</smiles>
NMR (250 MHz, $\left.\mathrm{CDCl}_{3}\right): \delta=0.34-0.40(\mathrm{~m}, 3 \mathrm{H}, \mathrm{cPr}-\mathrm{H}), 0.55-0.75$ (m, $3 \mathrm{H}, \mathrm{cPr}-\mathrm{H}), 0.81-0.88(\mathrm{~m}, 2 \mathrm{H}, \mathrm{cPr}-\mathrm{H}), 1.16\left(\mathrm{t},{ }^{3} J_{\mathrm{H}, \mathrm{H}}=7.0 \mathrm{~Hz}, 3\right.$ $\left.\mathrm{H}, \mathrm{CH}_{3}\right), 3.75(\mathrm{~s}, 1 \mathrm{H}, \mathrm{CH}), 4.02\left(\mathrm{q},{ }^{3} J_{\mathrm{H}, \mathrm{H}}=7.0 \mathrm{~Hz}, 2 \mathrm{H}, \mathrm{CH}_{2}\right), 5.29(\mathrm{~s}$, $1 \mathrm{H}, \mathrm{CH}), 7.18-7.31$ (m, $6 \mathrm{H}, \mathrm{Ar}-\mathrm{H}), 7.43-7.46$ (m, $2 \mathrm{H}, \mathrm{Ar}-\mathrm{H}), 7.55-$ 7.59 (m, $2 \mathrm{H}, \mathrm{Ar}-\mathrm{H}) .-{ }^{13} \mathrm{C} \mathrm{NMR}\left(62.9 \mathrm{MHz}, \mathrm{CDCl}_{3}\right.$, additional APT): $\delta=6.0\left(-, \mathrm{CH}_{2}, \mathrm{cPr}-\right.$ C), 7.2 (-, $\left.\mathrm{CH}_{2}, \mathrm{cPr}-\mathrm{C}\right), 7.6$ (-, $\left.\mathrm{CH}_{2}, \mathrm{cPr}-\mathrm{C}\right), 9.9$ (-, $\left.\mathrm{CH}_{2}, \mathrm{cPr}-\mathrm{C}\right), 14.2\left(+, \mathrm{CH}_{3}\right), 30.3$ (-, $\mathrm{C}_{\text {quat }}$, C-3), $60.6\left(-, \mathrm{OCH}_{2}\right), 66.3\left(-, \mathrm{C}_{\text {quat }}, \mathrm{C}-6\right), 72.2(+, \mathrm{CH}, *), 75.8(+, \mathrm{CH}, *), 126.8(+, \mathrm{CH}, \mathrm{Ar}-$ C), $127.3(+, 2 \mathrm{CH}, \mathrm{Ar}-\mathrm{C}), 127.7(+, \mathrm{CH}, \mathrm{Ar}-\mathrm{C}), 128.2(+, 2 \mathrm{CH}, \mathrm{Ar}-\mathrm{C}), 128.3$ (+, $2 \mathrm{CH}, \mathrm{Ar}-$ C), 128.6 (+, 2 CH, Ar-C), 140.9 (-, $\left.\mathrm{C}_{\text {quat }}, \mathrm{Ar}-\mathrm{C}\right), 142.3$ (-, $\left.\mathrm{C}_{\text {quat }}, \operatorname{Ar}-\mathrm{C}\right), 170.2$ (-, C=O). MS (EI): $m / z(\%)=363$ (5), 334 (5), 306 (5), 290 (45), 262 (15), 181 (25), 167 (100), 105 (30), 77 (20). $-\mathrm{C}_{23} \mathrm{H}_{25} \mathrm{NO}_{3}$ (363.45): calcd. C 76.01, H 6.93, N 3.85; found C 75.79, H 6.80, $\mathrm{N} 4.06$. 


\subsection{Synthesis of Compounds in Chapter 4}

5-Benzoyl-6-phenyl-5-azaspiro[2.3] hexane-4-one (107a): $\mathrm{KMnO}_{4}(721 \mathrm{mg}, 4.56 \mathrm{mmol})$ and<smiles>O=C(c1ccccc1)N1C(=O)C2(CC2)C1c1ccccc1</smiles>
18-crown-6 (15.0 mg, $0.057 \mathrm{mmol}, 5 \mathrm{~mol} \%)$ were added to a stirred solution of $\beta$-lactam 53a $(0.300 \mathrm{~g}, 1.14 \mathrm{mmol})$ in a mixture of acetone/acetic acid $85: 15(30 \mathrm{~mL})$. The solution was stirred at $60^{\circ} \mathrm{C}$ for $24 \mathrm{~h}$. After cooling to room temperature, the mixture was diluted with diethyl ether $(30 \mathrm{~mL})$, then an aq. sat. solution of $\mathrm{NaHCO}_{3}(50 \mathrm{~mL})$ was added in small portions under vigorous stirring, and the reaction mixture was stirred until the carbon dioxide evolution ceased. The organic phase was washed with brine $(2 \times 20 \mathrm{~mL})$, dried and concentrated under reduced pressure. Column chromatography $\left(R_{\mathrm{f}}=0.26,12 \mathrm{~g}\right.$ of silica gel, $2 \times 10 \mathrm{~cm}$ column, hexane/Et $\left.\mathrm{E}_{2} \mathrm{O} 3: 1\right)$ of the residue gave $107 \mathbf{a}(90.0 \mathrm{mg}, 28 \%)$ as a colorless solid, m.p. $121-123^{\circ} \mathrm{C}$. - IR (KBr): $\tilde{v}=3065 \mathrm{~cm}^{-1}, 3010,2950,1800,1675,1653,1448$. ${ }^{1} \mathrm{H}$ NMR $\left(250 \mathrm{MHz}, \mathrm{CDCl}_{3}\right): \delta=0.66-0.76(\mathrm{~m}, 1 \mathrm{H}, \mathrm{cPr}-\mathrm{H}), 1.28-1.39(\mathrm{~m}, 2 \mathrm{H}, \mathrm{cPr}-\mathrm{H})$, 1.43-1.53 (m, 1 H, cPr-H), 5.35 (s, 1 H, CH, 6-H), 7.29-7.43 (m, 5 H, Ar-H), 7.45-7.51 (m, 2 $\mathrm{H}, \mathrm{Ar}-\mathrm{H}), 7.55-7.62$ (m, $1 \mathrm{H}, \mathrm{Ar}-\mathrm{H}), 8.04-8.11$ (m, $2 \mathrm{H}, \mathrm{Ar}-\mathrm{H}) .-{ }^{13} \mathrm{C}$ NMR $(62.9 \mathrm{MHz}$, $\mathrm{CDCl}_{3}$, additional DEPT): $\delta=10.6(-, \mathrm{cPr}-\mathrm{C}), 11.7(-, \mathrm{cPr}-\mathrm{C}), 37.9\left(\mathrm{C}_{\text {quat }}, \mathrm{C}-3\right), 59.7(+, \mathrm{CH}$, C-6), 126.9 (+, 2 CH, Ar-C), 128.1 (+, 2 CH, Ar-C), 128.5 (+, CH, Ar-C), 128.7 (+, 2 CH, ArC), 129.9 (+, $2 \mathrm{CH}, \mathrm{Ar}-\mathrm{C}), 132.2$ ( $\left.\mathrm{C}_{\text {quat }}, \mathrm{Ar}-\mathrm{C}\right), 133.1$ (+, $\left.\mathrm{CH}, \mathrm{Ar}-\mathrm{C}\right), 136.4\left(\mathrm{C}_{\text {quat }}, \mathrm{Ar}-\mathrm{C}\right)$, $164.8\left(\mathrm{C}=\mathrm{O},{ }^{*}\right), 170.4\left(\mathrm{C}=\mathrm{O},{ }^{*}\right) .-\mathrm{MS}(\mathrm{EI}): m / z(\%)=277(36)\left[\mathrm{M}^{+}\right], 249(25), 129(32), 105$ (100), 77 (50). $-\mathrm{C}_{18} \mathrm{H}_{15} \mathrm{NO}_{2}$ (277.3): calcd. C 77.96, H 5.45, N 5.05; found C 77.69, H 5.35, $\mathrm{N}$ 4.82. Some starting material 53a $(200 \mathrm{mg}$, 67\%) was also recovered by column chromatography $\left(R_{\mathrm{f}}=0.11\right)$.

Methyl 5-Benzoyl-6-oxo-5-azaspiro[2.3]hexane-4-carboxylate (107b): Finely powdered $\mathrm{CrO}_{3}(0.202 \mathrm{~g}, 0.202 \mathrm{mmol})$ was added in one portion to a stirred<smiles>COC(=O)C1N(C(=O)c2ccccc2)C(=O)C12CC2</smiles>
solution of $\beta$-lactam $\mathbf{5 3 b}(247 \mathrm{mg}, 1.01 \mathrm{mmol})$ in acetic acid $(20 \mathrm{~mL})$ at ambient temp., and the resulting mixture was stirred at $60^{\circ} \mathrm{C}$ for an additional 3 days. After cooling to room temperature and dilution with diethyl ether $(20 \mathrm{~mL}), \mathrm{NaHCO}_{3}(15.0 \mathrm{~g}, 179 \mathrm{mmol})$ was added to the solution in several portions, and the reaction mixture was stirred until the carbon dioxide evolution ceased. The organic phase was washed with aq. sat. $\mathrm{NaHCO}_{3}$ solution in $20 \mathrm{~mL}$ portions until the evolution of carbon dioxide ceased, dried and concentrated under reduced pressure. Column chromatography $\left(R_{\mathrm{f}}=0.20,42 \mathrm{~g}\right.$ of 
silica gel, $3 \times 13 \mathrm{~cm}$ column, hexane/ $\left.\mathrm{Et}_{2} \mathrm{O} 2: 1\right)$ of the residue gave $\mathbf{1 0 7 b}(113 \mathrm{mg}, 44 \%)$ as a colorless solid, m.p. $92-93{ }^{\circ} \mathrm{C}$. - IR (KBr): $\tilde{v}=3090 \mathrm{~cm}^{-1}, 3077,2987,2961,1796,1734$, 1676, 1601, 1581, 1481, 1441. - ${ }^{1} \mathrm{H}$ NMR (300 MHz, $\left.\mathrm{CDCl}_{3}\right): \delta=1.07-1.33$ (m, $\left.2 \mathrm{H}, \mathrm{cPr}-\mathrm{H}\right)$, 1.34-1.56 (m, $2 \mathrm{H}, \mathrm{cPr}-\mathrm{H}), 3.80$ (s, $\left.3 \mathrm{H}, \mathrm{OCH}_{3}\right), 4.80$ (s, $\left.1 \mathrm{H}, \mathrm{CH}, 6-\mathrm{H}\right), 7.44-7.49$ (m, $2 \mathrm{H}$, Ar-H), 7.54-7.68 (m, $1 \mathrm{H}, \mathrm{Ar}-\mathrm{H}), 8.06-8.15$ (m, $2 \mathrm{H}, \mathrm{Ar}-\mathrm{H}) .-{ }^{13} \mathrm{C} \mathrm{NMR}\left(50.3 \mathrm{MHz}, \mathrm{CDCl}_{3}\right.$, additional APT): $\delta=9.6\left(-, \mathrm{CH}_{2}, \mathrm{cPr}-\mathrm{C}\right), 11.4\left(-, \mathrm{CH}_{2}, \mathrm{cPr}-\mathrm{C}\right), 34.4\left(-, \mathrm{C}_{\text {quat }}, \mathrm{C}-3\right), 52.6(+$, *), $56.0(+, *), 128.1$ (+, $2 \mathrm{CH}, \mathrm{Ar}-\mathrm{C}), 129.9$ (+, $2 \mathrm{CH}, \mathrm{Ar}-\mathrm{C}), 131.2\left(-, \mathrm{C}_{\text {quat }}, \mathrm{Ar}-\mathrm{C}\right), 133.3(+$, $\mathrm{CH}, \operatorname{Ar}-\mathrm{C}), 164.5(-, \mathrm{C}=\mathrm{O}, *), 167.6(-, \mathrm{C}=\mathrm{O}, *), 168.7(-, \mathrm{C}=\mathrm{O}, *) .-\mathrm{MS}(\mathrm{EI}): \mathrm{m} / z$ $(\%)=259(2)\left[\mathrm{M}^{+}\right], 228(5), 200(97), 105(100), 77(45)$. The structure of this $\beta$-lactam 107b was verified by X-ray crystal structure analysis. Some starting material 53b (72 mg, 29\%) was also recovered by column chromatography $\left(R_{\mathrm{f}}=0.12\right)$.

Deprotection of $\beta$-Lactam 53d: To a stirred solution of $\beta$-lactam 53d (900 mg, $3.72 \mathrm{mmol}$ ) in acetonitrile $(40 \mathrm{~mL})$ was added a solution of CAN $(6.63 \mathrm{~g}, 12.1 \mathrm{mmol})$ in water $(85 \mathrm{~mL})$ at $0{ }^{\circ} \mathrm{C}$. After an additional stirring for 20 minutes at the same temp. and for $1 \mathrm{~h}$ at ambient temp., the mixture was extracted with ethyl acetate $(3 \times 50 \mathrm{~mL})$. The combined organic layers were washed successively with a $10 \%$ aq. $\mathrm{Na}_{2} \mathrm{SO}_{3}$ solution $(2 \times 50 \mathrm{~mL})$, a $5 \%$ aq. $\mathrm{NaHCO}_{3}$ solution $(2 \times 50 \mathrm{~mL})$ and brine $(50 \mathrm{~mL})$, dried and concentrated under reduced pressure. Column chromatography (hexane $/ \mathrm{Et}_{2} \mathrm{O} 1: 2,75 \mathrm{~g}$ of silica gel, $3.5 \times 16 \mathrm{~cm}$ column) of the residue gave 6-oxo-5-azaspiro[2.3]hexane-4-carbonitrile (108) (172 $\mathrm{mg}, 38 \%)$ as a colorless solid, m.p. $\quad 72-73^{\circ} \mathrm{C}, \quad R_{\mathrm{f}}=0.15$, and $\mathbf{5}$-(p-methoxybenzoyl)-6-oxo-5-azaspiro[2.3] hexane-4-carbonitrile (107d) $(371 \mathrm{mg}, 39 \%)$ as a colorless solid, m.p. 109$110^{\circ} \mathrm{C}, R_{\mathrm{f}}=0.38$ (hexane $\left./ \mathrm{Et}_{2} \mathrm{O} 1: 4\right)$.

108: - IR (KBr): $\tilde{v}=3250 \mathrm{~cm}^{-1}, 3097,2720,2249,1763,1331 .-{ }^{1} \mathrm{H}$ NMR $(250 \mathrm{MHz}$,<smiles>N#CC1NC(=O)C12CC2</smiles>
$\left.\mathrm{CDCl}_{3}\right): \delta=1.26-1.37(\mathrm{~m}, 2 \mathrm{H}, \mathrm{cPr}-\mathrm{H}), 1.41-1.48(\mathrm{~m}, 2 \mathrm{H}, \mathrm{cPr}-\mathrm{H}), 4.44$ (s, 1 $\mathrm{H}, \mathrm{CH}, 4-\mathrm{H}), 6.40(\mathrm{~s}, 1 \mathrm{H}, \mathrm{NH}) .-{ }^{13} \mathrm{C} \mathrm{NMR}\left(62.9 \mathrm{MHz}, \mathrm{CDCl}_{3}\right.$, additional DEPT): $\delta=9.1(-, \mathrm{cPr}-\mathrm{C}), 9.8(-, \mathrm{cPr}-\mathrm{C}), 39.8\left(\mathrm{C}_{\text {quat }}, \mathrm{C}-3\right), 43.6(+, \mathrm{CH})$, $116.9\left(\mathrm{C}_{\text {quat }}, \mathrm{CN}\right), 171.5\left(\mathrm{C}_{\text {quat, }} \mathrm{C}=\mathrm{O}\right) .-\mathrm{MS}(\mathrm{EI}): m / z(\%)=122(12)\left[\mathrm{M}^{+}\right], 79(50), 52(100)$. $-\mathrm{C}_{6} \mathrm{H}_{6} \mathrm{~N}_{2} \mathrm{O}$ (122.1) calcd. C 59.01, H 4.95, N 22.94; found C 59.20, H 5.08, N 22.81. 
107d: - IR (KBr): $\tilde{v}=3084 \mathrm{~cm}^{-1}, 3005,2977,2938,2843,2251,1798,1666,1603,1576$,<smiles>COc1ccc(C(=O)N2C(=O)C3(CC3)C2C#N)cc1</smiles>
1514. $-{ }^{1} \mathrm{H}$ NMR $\left(250 \mathrm{MHz}, \mathrm{CDCl}_{3}\right): \delta=1.47-1.67(\mathrm{~m}, 4 \mathrm{H}, \mathrm{cPr}-\mathrm{H}), 3.89$ (s, $\left.3 \mathrm{H}, \mathrm{OCH}_{3}\right), 4.92$ (s, $\left.1 \mathrm{H}, \mathrm{CH}, \mathrm{H}-4\right), 6.95-7.01$ (m, $\left.2 \mathrm{H}, \mathrm{Ar}-\mathrm{H}\right), 8.08-$ $8.14(\mathrm{~m}, 2 \mathrm{H}, \mathrm{Ar}-\mathrm{H}) .-{ }^{13} \mathrm{C} \mathrm{NMR}\left(62.9 \mathrm{MHz}, \mathrm{CDCl}_{3}\right.$, additional DEPT): $\delta=11.4(-, \mathrm{cPr}-\mathrm{C}), 12.2(-, \mathrm{cPr}-\mathrm{C}), 34.8\left(\mathrm{C}_{\text {quat }}, \mathrm{C}-3\right), 44.4(+, \mathrm{CH}, \mathrm{C}-4)$, $55.5\left(+, \mathrm{CH}_{3}\right), 113.8(+, 2 \mathrm{CH}, \mathrm{Ar}-\mathrm{C}), 115.4\left(\mathrm{C}_{\text {quat }}, \mathrm{CN}\right), 122.2\left(\mathrm{C}_{\text {quat }}, \mathrm{Ar}-\mathrm{C}\right)$, 132.6 (+, $2 \mathrm{CH}, \mathrm{Ar}-\mathrm{C}), 163.3\left(\mathrm{C}_{\text {quat }}, *\right), 164.3\left(\mathrm{C}_{\text {quat }}, *\right), 166.3\left(\mathrm{C}_{\text {quat }}, *\right)$. MS (EI): $m / z(\%)=256(20)\left[\mathrm{M}^{+}\right], 135$ (100), 92 (9), 77 (9). $-\mathrm{C}_{14} \mathrm{H}_{12} \mathrm{~N}_{2} \mathrm{O}_{3}$

(256.3): calcd. C 65.62, H 4.72, N 10.93; found C 65.75, H 4.61, N 11.15.

Methyl 6-oxo-5-azaspiro[2.3]hexane-4-carboxylate (109): To a stirred solution of $\beta$-lactam<smiles>COC(=O)C1NC(=O)C12CC2</smiles>
77d-Me $(0.114 \mathrm{~g}, 0.41 \mathrm{mmol})$, in acetonitrile $(3.0 \mathrm{~mL})$ was added a solution of ceric ammonium nitrate (CAN) $(0.50 \mathrm{~g}, 0.90 \mathrm{mmol})$ in water/acetonitrile $(2.0 / 3.0 \mathrm{~mL})$. After $1 \mathrm{~h}$ of stirring at room temperature additional CAN $(0.110 \mathrm{~g}, 0.20 \mathrm{mmol})$ was added. After $30 \mathrm{~min}$, $\mathrm{Na}_{2} \mathrm{~S}_{2} \mathrm{O}_{3} \cdot 5 \cdot \mathrm{H}_{2} \mathrm{O}(0.273 \mathrm{~g}, 1.1 \mathrm{mmol})$ was added, and the color of the suspension turned to a lighter yellow. $\mathrm{NaHCO}_{3}$ was also added until the $\mathrm{pH}$ turned from 1 to 7 . The suspension was evaporated to dryness, methanol $(15 \mathrm{~mL})$ was added, and the suspension obtained was filtered through a pad of silica gel (soaked with diethyl ether) to eliminate salts. The column was washed with methanol ( $\sim 200 \mathrm{~mL})$, and the $68 \mathrm{mg}$ of crude product, obtained after evaporation of the solvent, was purified by column chromatography. The $\beta$-lactam $109\left(R_{\mathrm{f}}=0.47,70 \mathrm{~g}\right.$ of flash silica gel, $20 \times 3 \mathrm{~cm}$ column, $\mathrm{CH}_{2} \mathrm{Cl}_{2} / \mathrm{MeOH}$ ( $1 \mathrm{vol} \% \mathrm{NH}_{4} \mathrm{OH}$ conc.) 50:1) was obtained as a light-yellow oil (58 mg, 90\%). - IR (film): $\tilde{v}=3006 \mathrm{~cm}^{-1}, 2955,1792,1733,1438$, 1289. $-{ }^{1} \mathrm{H}$ NMR $\left(250 \mathrm{MHz}, \mathrm{CDCl}_{3}\right): \delta=0.87-0.97$ (m, $\left.1 \mathrm{H}, \mathrm{cPr}-\mathrm{H}\right), 1.08-1.31$ (m, $3 \mathrm{H}, \mathrm{cPr}-$ $\mathrm{H}), 3.73\left(\mathrm{~s}, 3 \mathrm{H}, \mathrm{OCH}_{3}\right), 4.24(\mathrm{~s}, 1 \mathrm{H}, \mathrm{H}-4) .-{ }^{13} \mathrm{C} \mathrm{NMR}\left(62.9 \mathrm{MHz}, \mathrm{CDCl}_{3}\right.$, additional DEPT): $\delta=7.2\left(-\right.$, cPr-C), 8.5 (-, cPr-C), 38.3 (C Cuat $\left._{\text {, }}-3\right), 52.3(+, *), 54.9(+, *), 170.7$ $\left(\mathrm{C}=\mathrm{O},{ }^{*}\right), 172.8(\mathrm{C}=\mathrm{O}, *) .-\mathrm{MS}(\mathrm{EI}): \mathrm{m} / z(\%)=155(1), 135$ (15), 112 (22), 96 (30), 85 (62), 83 (100), 82 (8), 69 (8), 48 (50), 46 (22). $-\mathrm{C}_{7} \mathrm{H}_{9} \mathrm{NO}_{3}$ (155.15): calcd. C 54.19, H 5.85, N 9.03; found C 53.94, H 5.74, N 8.78. 
tert-Butyl 4-Cyano-6-oxo-5-azaspiro[2.3]hexane-5-carboxylate (110): Di-tert-butyl pyro-<smiles>CC(C)(C)OC(=O)N1C(=O)C2(CC2)C1C#N</smilescarbonate $\left(\mathrm{Boc}_{2} \mathrm{O}\right) \quad(873 \mathrm{mg}, 4.00 \mathrm{mmol})$ and DMAP $(24.0 \mathrm{mg}$, $0.196 \mathrm{mmol}$ ) were added in one portion to a stirred solution of $\beta$-lactam $108(245 \mathrm{mg}, 2.01 \mathrm{mmol})$ in anhydrous acetonitrile $(30 \mathrm{~mL})$ at $0{ }^{\circ} \mathrm{C}$. The reaction mixture was stirred at ambient temperature for an additional $3 \mathrm{~h}$, diluted with dichloromethane $(30 \mathrm{~mL})$, washed successively with $10 \%$ aq. $\mathrm{Na}_{2} \mathrm{SO}_{3}$ solution $(2 \times 20 \mathrm{~mL})$, aq. sat. $\mathrm{NaHCO}_{3}$ solution of $(2 \times 20 \mathrm{~mL})$ and brine $(2 \times 20 \mathrm{~mL})$, dried and concentrated under reduced pressure. Column chromatography $\left(R_{\mathrm{f}}=0.10,12 \mathrm{~g}\right.$ of silica gel, $2 \times 10 \mathrm{~cm}$ column, hexane/Et $\left.{ }_{2} \mathrm{O} 2: 1\right)$ furnished 110 (346 mg, 78\%) as a colorless solid, m.p. $87{ }^{\circ} \mathrm{C} .-\mathrm{IR}(\mathrm{KBr}): \tilde{v}=3012 \mathrm{~cm}^{-1}, 2992,2250,1823,1717 .-{ }^{1} \mathrm{H}$ NMR $(300 \mathrm{MHz}$, $\left.\mathrm{CDCl}_{3}\right): \delta=1.35-1.46(\mathrm{~m}, 2 \mathrm{H}, \mathrm{cPr}-\mathrm{H}), 1.48-1.64(\mathrm{~m}, 2 \mathrm{H}, \mathrm{cPr}-\mathrm{H}), 1.56\left(\mathrm{~s}, 9 \mathrm{H}, 3 \mathrm{CH}_{3}\right), 4.64$ (s, $1 \mathrm{H}, \mathrm{CH}, 4-\mathrm{H}) .-{ }^{13} \mathrm{C}$ NMR $\left(50.3 \mathrm{MHz}, \mathrm{CDCl}_{3}\right.$, additional DEPT): $\delta=10.6$ (-, cPr-C), $11.4(-, \mathrm{cPr}-\mathrm{C}), 28.0\left(+, 3 \mathrm{CH}_{3}\right), 37.0\left(\mathrm{C}_{\text {quat }}, \mathrm{C}-3\right), 45.9(+, \mathrm{CH}, \mathrm{C}-4), 85.1\left(\mathrm{C}_{\text {quat }}, t \mathrm{Bu}\right), 115.0$ $(\mathrm{CN}), 145.7\left(\mathrm{C}=\mathrm{O},{ }^{*}\right), 166.6(\mathrm{C}=\mathrm{O}, *) .-\mathrm{MS}(\mathrm{EI}): m / z(\%)=223(1)\left[\mathrm{M}+\mathrm{H}^{+}\right], 167(9), 149$ (30), 57 (100). - MS (DCI): $m / z(\%)=684(5)\left[3 \mathrm{M}+\mathrm{NH}_{4}^{+}\right], 462(40)\left[2 \mathrm{M}+\mathrm{NH}_{4}^{+}\right], 257$ (72) $\left[\mathrm{M}+\mathrm{NH}_{3}+\mathrm{NH}_{4}^{+}\right], 240$ (100) $\left[\mathrm{M}+\mathrm{NH}_{4}^{+}\right] .-\mathrm{C}_{11} \mathrm{H}_{14} \mathrm{~N}_{2} \mathrm{O}_{3}$ (222.2): calcd. C 59.45, $\mathrm{H}$ 6.35, N 12.61; found C 59.55, H 6.14, N 12.47.

\section{5-tert-Butyl-4-methyl 6-oxo-5-azaspiro[2.3]hexane-4,5-dicarboxylate (111): Di-tert-butyl}

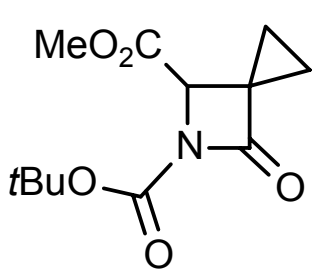
pyrocarbonate $\left(\mathrm{Boc}_{2} \mathrm{O}\right)(0.113 \mathrm{~g}, 0.52 \mathrm{mmol})$ and DMAP $(3 \mathrm{mg}$, $0.03 \mathrm{mmol})$ were added in one portion to $\beta$-lactam $109(40.0 \mathrm{mg}$, $0.26 \mathrm{mmol})$ in anhydrous acetonitrile $(3.90 \mathrm{~mL})$ at $0{ }^{\circ} \mathrm{C}$. After $1 \mathrm{~h}$, the starting material was no longer detectable by TLC. The reaction mixture was stirred at ambient temperature for an additional $13 \mathrm{~h}$, diluted with dichloromethane $(20 \mathrm{~mL})$, washed successively with $5 \%$ aq. $\mathrm{NaHSO}_{3}$ solution $(3 \times 20 \mathrm{~mL})$, aq. satd. $\mathrm{NaHCO}_{3}$ solution $(1 \times 20 \mathrm{~mL})$, dried and concentrated under reduced pressure. Column chromatography $\left(R_{\mathrm{f}}=0.17,12 \mathrm{~g}\right.$ of silica gel, $2 \times 8 \mathrm{~cm}$ column, hexane $\left./ \mathrm{Et}_{2} \mathrm{O} 2: 1\right)$ furnished 111 (54 mg, 82\%) as a colorless solid, m.p. 69-70 ${ }^{\circ} \mathrm{C}$. - IR (film): $\tilde{v}=2978 \mathrm{~cm}^{-1}, 2950$, 1814, 1743, 1723, 1382, 1319, 1151. - ${ }^{1} \mathrm{H}$ NMR $\left(250 \mathrm{MHz}, \mathrm{CDCl}_{3}\right): \delta=0.95-1.01(\mathrm{~m}, 1 \mathrm{H}$, cPr-H), 1.24-1.44 (m, 3 H, cPr-H), 1.51 (s, 9 H, $\left.3 \mathrm{CH}_{3}\right), 3.78$ (s, $\left.3 \mathrm{H}, \mathrm{OCH}_{3}\right), 4.48$ (s, $1 \mathrm{H}, 4-$ H). $-{ }^{13} \mathrm{C}$ NMR (50.3 MHz, $\mathrm{CDCl}_{3}$, additional DEPT): $\delta=8.7$ (-, cPr-C), 10.5 (-, cPr-C), $27.9\left(+, 3 \mathrm{CH}_{3}\right), 36.1\left(\mathrm{C}_{\text {quat }}, \mathrm{C}-3\right), 51.5(+, *), 57.2(+, *), 83.6\left(\mathrm{C}_{\text {quat }}, t \mathrm{Bu}\right), 168.4(\mathrm{C}=\mathrm{O}, *)$, $168.7(2 \mathrm{C}=\mathrm{O}, *)$. - MS (EI): $m / z(\%)=200$ (1), 140 (19), 96 (10), 57 (100). - MS (DCI): $m / z$ 
$(\%)=273(100)\left[\mathrm{M}+\mathrm{NH}_{4}^{+}\right] \cdot-\mathrm{C}_{12} \mathrm{H}_{17} \mathrm{NO}_{5}$ (255.3): calcd. C 56.46, H 6.71, N 5.49; found $\mathrm{C}$ 56.50, H 6.89, N 5.54.

Reaction of N-Acylated $\beta$-Lactams 107a,b, 11 with tert-Butyl Glycinate (102) and tertButyl (S)-Phenylalaninate (115). General Procedure 9

(GP 9): tert-Butyl aminoester 102 [or its hydrochloride in the presence of triethylamine (1 equiv.)] was added to a solution of the respective $\beta$-lactam 107a,b or 110 in DMF, and the resulting mixture was stirred at $152{ }^{\circ} \mathrm{C}$ (if not otherwise specified) for the indicated time. After cooling to ambient temperature, diethyl ether $(20 \mathrm{~mL})$ was added, and the organic layer was washed with water $(10 \mathrm{~mL})$, brine $(2 \times 10 \mathrm{~mL})$, and dried over $\mathrm{Na}_{2} \mathrm{SO}_{4}$. After filtration, the solution was concentrated under reduced pressure, and the crude product was purified by column chromatography on silica gel.

tert-Butyl [(5-Benzoyl-6-oxo-5-azaspiro[2.3]hexane-4-carbonyl)amino]acetate (114): Co-<smiles></smileslumn chromatography $\left(R_{\mathrm{f}}=0.10,12 \mathrm{~g}\right.$ of silica gel, $2 \times 10 \mathrm{~cm}$ column, hexane/ $\mathrm{Et}_{2} \mathrm{O} 1: 1$ ) of the residue obtained from the $\beta$ lactam 107b (113 mg, $0.436 \mathrm{mmol})$ and glycinate 102 (171 mg, $1.31 \mathrm{mmol})$ in DMF $(10 \mathrm{~mL})$ according to GP $9(20 \mathrm{~h})$ gave 114 (80 mg, 51\%) as a colorless solid, m.p. $112-115^{\circ} \mathrm{C}$. - IR (KBr): $\tilde{v}=3400 \mathrm{~cm}^{-1}$ (br.), 2982, 2925, 2853, 1790, 1719, 1644, 1604, 1581, 1516, 1487. - ${ }^{1} \mathrm{H}$ NMR (250 MHz, $\left.\mathrm{CDCl}_{3}\right): \delta=1.08-1.19$ (m, $1 \mathrm{H}, \mathrm{cPr}-\mathrm{H}), 1.31-1.45$ (m, $2 \mathrm{H}, \mathrm{cPr}-\mathrm{H}), 1.48$ (s, $\left.9 \mathrm{H}, 3 \mathrm{CH}_{3}\right), 1.58-1.66$ (m, $\left.1 \mathrm{H}, \mathrm{cPr}-\mathrm{H}\right)$, $4.27\left(\mathrm{~s}, 2 \mathrm{H}, \mathrm{CH}_{2} \mathrm{CO}\right), 5.03\left(\mathrm{~d},{ }^{3} J_{\mathrm{H}, \mathrm{H}}=7.4 \mathrm{~Hz}, 1 \mathrm{H}, \mathrm{CH}, 4-\mathrm{H}\right), 6.91\left(\mathrm{~d},{ }^{3} J_{\mathrm{H}, \mathrm{H}}=7.4 \mathrm{~Hz}, 1 \mathrm{H}\right.$, $\mathrm{NH}), 7.39-7.47$ (m, $2 \mathrm{H}, \mathrm{Ar}-\mathrm{H}), 7.5-7.57$ (m, $3 \mathrm{H}, \mathrm{Ar}-\mathrm{H}), 7.75-7.81$ (m, $2 \mathrm{H}, \mathrm{Ar}-\mathrm{H}) .-{ }^{13} \mathrm{C}$ NMR (150 MHz, $\mathrm{CDCl}_{3}$, additional APT): $\delta=13.3\left(-, \mathrm{CH}_{2}, \mathrm{cPr}-\mathrm{C}\right), 15.2\left(-, \mathrm{CH}_{2}, \mathrm{cPr}-\mathrm{C}\right)$, 27.2 (-, $\left.\mathrm{C}_{\text {quat }}, \mathrm{C}-3\right), 28.0\left(+, 3 \mathrm{CH}_{3}\right), 40.7\left(-, \mathrm{CH}_{2}, \mathrm{C}-1\right), 53.4(+, \mathrm{CH}, \mathrm{C}-4), 83.2$ (-, $\mathrm{C}_{\text {quat }}$, tBu), 127.2 (+, $2 \mathrm{CH}, \mathrm{Ar}-\mathrm{C}), 128.7$ (+, $2 \mathrm{CH}, \mathrm{Ar}-\mathrm{C}), 132.3$ (+, CH, Ar-C), 132.5 (-, $\mathrm{C}_{\text {quat }}, \mathrm{Ar}-$ C), $165.9(\mathrm{C}=\mathrm{O}, *), 167.8(\mathrm{C}=\mathrm{O}, *), 174.7(\mathrm{C}=\mathrm{O}, *), 177.4(\mathrm{C}=\mathrm{O}, *) .-\mathrm{MS}(\mathrm{DCI}): m / z$ $(\%)=734(10)\left[2 \mathrm{M}+\mathrm{NH}_{4}^{+}\right], 376(100)\left[\mathrm{M}+\mathrm{NH}_{4}^{+}\right] .-\mathrm{C}_{19} \mathrm{H}_{22} \mathrm{~N}_{2} \mathrm{O}_{5}$ (358.39) calcd. C 63.67, H 6.19 N 7.82; found C 63.33, H 5.95, N 7.71. 
tert-Butyl \{[1-(Benzoylaminophenylmethyl)cyclopropylcarbonyl]amino\}acetate (116):<smiles>CCCOC(=O)CNC(=O)C1(C(NC(=O)c2ccccc2)c2ccccc2)CC1</smiles>

Column chromatography $\left(R_{\mathrm{f}}=0.17,15 \mathrm{~g}\right.$ of silica gel,

$2 \times 10 \mathrm{~cm}$ column, hexane $\left./ \mathrm{Et}_{2} \mathrm{O} 1: 2\right)$ of the residue obtained from the $\beta$-lactam 107a $(243 \mathrm{mg}$, $0.877 \mathrm{mmol}$ ) and glycinate $102(354 \mathrm{mg}, 2.7 \mathrm{mmol})$ in DMF (35 mL) according to GP 9 (12 h) gave $116(217 \mathrm{mg}, 61 \%)$ as a colorless solid, m.p. $133-134{ }^{\circ} \mathrm{C}$. - IR (KBr): $\tilde{v}=3311 \mathrm{~cm}^{-1}, 3238,3064,2974,1754,1734,1656,1636 .-{ }^{1} \mathrm{H}$ NMR $\left(300 \mathrm{MHz}, \mathrm{CDCl}_{3}\right)$ : $\delta=0.99-1.29(\mathrm{~m}, 4 \mathrm{H}, \mathrm{cPr}-\mathrm{H}), 1.36\left(\mathrm{~s}, 9 \mathrm{H}, 3 \mathrm{CH}_{3}\right), 3.71\left(\mathrm{dd},{ }^{2} J_{\mathrm{H}, \mathrm{H}}=18.3,{ }^{3} J_{\mathrm{H}, \mathrm{H}}=5.0 \mathrm{~Hz}, 1\right.$ $\left.\mathrm{H}, \mathrm{CH}_{2} \mathrm{CO}\right), 3.78\left(\mathrm{dd},{ }^{2} J_{\mathrm{H}, \mathrm{H}}=18.3,{ }^{3} J_{\mathrm{H}, \mathrm{H}}=5.0 \mathrm{~Hz}, 1 \mathrm{H}, \mathrm{CH}_{2} \mathrm{CO}\right), 4.76\left(\mathrm{~d},{ }^{3} J_{\mathrm{H}, \mathrm{H}}=8.7 \mathrm{~Hz}, 1 \mathrm{H}\right.$, $\left.\mathrm{CH}, 2^{\prime}-\mathrm{H}\right), 5.81\left(\mathrm{t},{ }^{3} J_{\mathrm{H}, \mathrm{H}}=5.0 \mathrm{~Hz}, 1 \mathrm{H}, \mathrm{NH}\right), 7.12-7.27(\mathrm{~m}, 3 \mathrm{H}, \mathrm{Ar}-\mathrm{H}), 7.32-7.47(\mathrm{~m}, 5 \mathrm{H}$, Ar-H), 7.85-7.89 (m, $2 \mathrm{H}, \mathrm{Ar}-\mathrm{H}), 8.66\left(\mathrm{~d},{ }^{3} J_{\mathrm{H}, \mathrm{H}}=8.7 \mathrm{~Hz}, 1 \mathrm{H}, \mathrm{NH}\right) .-{ }^{13} \mathrm{C}$ NMR $(75.5 \mathrm{MHz}$, $\mathrm{CDCl}_{3}$, additional APT): $\delta=13.1\left(-, \mathrm{CH}_{2}, \mathrm{cPr}-\mathrm{C}\right), 14.1\left(-, \mathrm{CH}_{2}, \mathrm{cPr}-\mathrm{C}\right), 27.9\left(+, 3 \mathrm{CH}_{3}\right), 29.5$ (-, $\left.\mathrm{C}_{\text {quat }}\right), 41.8\left(-, \mathrm{CH}_{2}, \mathrm{C}-1\right), 58.3\left(+, \mathrm{CH}, \mathrm{C}-2\right.$ ') $, 82.5\left(-, \mathrm{C}_{\text {quat }}, t \mathrm{Bu}\right), 126.5(+, 2 \mathrm{CH}, \mathrm{Ar}-\mathrm{C})$, $127.2(+, 2 \mathrm{CH}, \mathrm{Ar}-\mathrm{C}), 127.4$ (+, $\mathrm{CH}, \mathrm{Ar}-\mathrm{C}), 128.5$ (+, $4 \mathrm{CH}, \mathrm{Ar}-\mathrm{C}), 131.5$ (+, CH, Ar-C), 134.1 (-, $\left.\mathrm{C}_{\text {quat }}, \mathrm{Ar}-\mathrm{C}\right), 140.2$ (-, $\left.\mathrm{C}_{\text {quat }}, \mathrm{Ar}-\mathrm{C}\right), 166.5$ (-, C=O, *), $168.8(-, \mathrm{C}=\mathrm{O}, *), 173.5$ (-, $\mathrm{C}=\mathrm{O}, *) .-\mathrm{MS}(\mathrm{EI}): m / z(\%)=408(2)\left[\mathrm{M}^{+}\right], 335$ (10), 277 (85), 250 (15), 210 (15), 105 (100), 77 (30), 57 (22). - MS (DCI): $m / z(\%)=426(55)\left[\mathrm{M}+\mathrm{NH}_{4}{ }^{+}\right], 409$ (100) $\left[\mathrm{M}+\mathrm{H}^{+}\right] .-$ $\mathrm{C}_{24} \mathrm{H}_{28} \mathrm{~N}_{2} \mathrm{O}_{4}$ (408.5): calcd. C 70.57, H 6.91, N 6.86; found C 70.76, H 7.10, N 7.26.

tert-Butyl\{[1(tert-Butoxycarbonylaminocyanomethyl)cyclopropylcarbonyl]amino\}acetate<smiles>CCCCOC(=O)CNC(=O)C1(C(C#N)NC(=O)OCCC)CC1</smiles>
(117): The colorless solid $(0.20 \mathrm{~g}, 84 \%)$ obtained from $\beta$-lactam 110 (150 mg, $0.67 \mathrm{mmol})$, tert-butyl glycinate hydrochloride (12.HCl) $\quad(195 \mathrm{mg}$, $1.16 \mathrm{mmol})$ and triethylamine $(118 \mathrm{mg}, 162 \mu \mathrm{L}$, $1.16 \mathrm{mmol})$ in DMF (16 $\mathrm{mL})$ according to GP $9(12 \mathrm{~h})$ after evaporation of the solvent was essentially pure acetate 117. An analytical sample was obtained by column chromatography $\left(R_{\mathrm{f}}=0.70,20 \mathrm{~g}\right.$ of silica gel, $2 \times 16 \mathrm{~cm}$ column, $\left.\mathrm{Et}_{2} \mathrm{O}\right)$, m.p. $86-88^{\circ} \mathrm{C}$. $-\mathrm{IR}(\mathrm{KBr})$ : $\tilde{v}=3311 \mathrm{~cm}^{-1}, 3096,2989,2939,1751,1688,1638,1550,1511 .-{ }^{1} \mathrm{H}$ NMR $(300 \mathrm{MHz}$, $\left.\mathrm{CDCl}_{3}\right): \delta=1.08-1.16(\mathrm{~m}, 1 \mathrm{H}, \mathrm{cPr}-\mathrm{H}), 1.17-1.28(\mathrm{~m}, 2 \mathrm{H}, \mathrm{cPr}-\mathrm{H}), 1.30-1.37$ (m, $1 \mathrm{H}, \mathrm{cPr}-$ $\mathrm{H}), 1.44\left(\mathrm{~s}, 9 \mathrm{H}, 3 \mathrm{CH}_{3}\right), 1.47\left(\mathrm{~s}, 9 \mathrm{H}, 3 \mathrm{CH}_{3}\right), 3.87\left(\mathrm{dd},{ }^{2} J_{\mathrm{H}, \mathrm{H}}=18.4,{ }^{3} J_{\mathrm{H}, \mathrm{H}}=4.4 \mathrm{~Hz}, 1 \mathrm{H}\right.$, $\left.\mathrm{CH}_{2} \mathrm{CO}\right), 3.94\left(\mathrm{dd},{ }^{2} J_{\mathrm{H}, \mathrm{H}}=18.4,{ }^{3} J_{\mathrm{H}, \mathrm{H}}=4.4 \mathrm{~Hz}, 1 \mathrm{H}, \mathrm{CH}_{2} \mathrm{CO}\right), 4.24\left(\mathrm{~d},{ }^{3} J_{\mathrm{H}, \mathrm{H}}=9.2 \mathrm{~Hz}, 1 \mathrm{H}\right.$, $\mathrm{CH}, 2$ '-H), 5.83 (br. t, $\left.{ }^{3} J_{\mathrm{H}, \mathrm{H}}=4.4 \mathrm{~Hz}, 1 \mathrm{H}, \mathrm{NH}\right), 6.20$ (br. d, $\left.{ }^{3} J_{\mathrm{H}, \mathrm{H}}=9.2 \mathrm{~Hz}, 1 \mathrm{H}, \mathrm{NH}\right) .-{ }^{13} \mathrm{C}$ NMR (50.3 MHz, $\mathrm{CDCl}_{3}$, additional APT): $\delta=13.2\left(-, \mathrm{CH}_{2}, \mathrm{cPr}-\mathrm{C}\right), 14.8$ (-, $\left.\mathrm{CH}_{2}, \mathrm{cPr}-\mathrm{C}\right)$, 
27.9 (-, $\left.\mathrm{C}_{\text {quat }}\right), 28.0\left(+, 3 \mathrm{CH}_{3}\right), 28.2\left(+, 3 \mathrm{CH}_{3}\right), 41.9\left(-, \mathrm{CH}_{2}, \mathrm{C}-1\right), 47.0(+, \mathrm{CH}, \mathrm{C}-2$ ') $), 81.2$ $\left(-, \mathrm{C}_{\text {quat }}, t \mathrm{Bu}\right), 82.8\left(-, \mathrm{C}_{\text {quat }}, t \mathrm{Bu}\right), 117.4(-, \mathrm{CN}), 168.8(-, 2 \mathrm{C}=\mathrm{O}, *), 171.2(-, \mathrm{C}=\mathrm{O}, *)$. MS (EI): $m / z(\%)=353(2)\left[\mathrm{M}^{+}\right], 297$ (15), 224 (28), 197 (42), 57 (100). - MS (DCI): $m / z$ $(\%)=724(10)\left[2 \mathrm{M}+\mathrm{NH}_{4}{ }^{+}\right], 707(18)\left[2 \mathrm{M}+\mathrm{H}^{+}\right], 371(85)\left[\mathrm{M}+\mathrm{NH}_{4}{ }^{+}\right], 354(100)[\mathrm{M}+$ $\mathrm{H}^{+}$]. $-\mathrm{C}_{17} \mathrm{H}_{27} \mathrm{~N}_{3} \mathrm{O}_{5}$ (353.41): calcd. C 57.77, H 7.70, N 11.89; found C 57.49, H 7.58, N 11.81 .

tert-Butyl (2S,2'S)-2-\{[1-(tert-Butoxycarbonylaminocyanomethyl)cyclopropylcarbo-nyl]amino\}-3-phenylpropionate $\left[\left(2 S, 2^{\prime} S\right)-118\right]$ and tert-Butyl $\left(2 S, 2^{\prime} R\right)-2-\{[1-(t e r t-B u t o x y-$ carbonylaminocyanomethyl)cyclopropylcarbonyl]amino\}-3-phenylpropionate $\left[\left(2 S, 2^{\prime} R\right)-\right.$

118]: Column chromatography (44 g of silica gel, $3 \times 13 \mathrm{~cm}$ column, hexane $/ \mathrm{Et}_{2} \mathrm{O} 1: 1$ ) of the residue obtained from the $\beta$-lactam 110 (184 mg, $0.83 \mathrm{mmol})$, tert-butyl $(S)$-phenylalaninate hydrochloride $(\mathbf{1 4} \cdot \mathbf{H C l})(428 \mathrm{mg}, 1.66 \mathrm{mmol})$ and $\mathrm{Et}_{3} \mathrm{~N}(168 \mathrm{mg}, 230 \mu \mathrm{L}, 1.66 \mathrm{mmol})$ in DMF $(33 \mathrm{~mL})$ according to GP $9\left(60^{\circ} \mathrm{C}, 12 \mathrm{~h}\right)$ gave $(\mathbf{2 S}, \mathbf{2} \mathbf{S})-\mathbf{1 1 8}(155 \mathrm{mg}, 42 \%)$ and (2S,2'R)-118 (143 mg, 39\%) as colorless solids.

The diastereoisomer $\left(\mathbf{2} S, \mathbf{2}^{\prime} \boldsymbol{S}\right)$-118: $R_{\mathrm{f}}=0.34$, m.p. $101-102{ }^{\circ} \mathrm{C},-[\alpha]_{D}^{20}=+53.4(c=0.5$ in<smiles>CCCCOC(=O)C(Cc1ccccc1)NC(=O)C1([C@H](C#N)NC(=O)OC(C)(C)C)CC1</smiles>
$\left.\mathrm{CHCl}_{3}\right)$. - IR (KBr): $\tilde{v}=3438 \mathrm{~cm}^{-1}, 3426,3090$, 2981, 2935, 2247, 1738, 1719, 1650, 1540, 1524, 1370. - ${ }^{1} \mathrm{H}$ NMR $\left(250 \mathrm{MHz}, \mathrm{CDCl}_{3}\right): \delta=1.00-1.22$ $(\mathrm{m}, 4 \mathrm{H}, \mathrm{cPr}-\mathrm{H}), 1.41\left(\mathrm{~s}, 9 \mathrm{H}, 3 \mathrm{CH}_{3}\right), 1.43\left(\mathrm{~s}, 9 \mathrm{H}, 3 \mathrm{CH}_{3}\right), 3.06\left(\mathrm{dd},{ }^{2} J_{\mathrm{H}, \mathrm{H}}=15.0\right.$, $\left.{ }^{3} J_{\mathrm{H}, \mathrm{H}}=5.0 \mathrm{~Hz}, 1 \mathrm{H}, \mathrm{CH}_{2} \mathrm{Ph}\right), 3.15\left(\mathrm{dd},{ }^{2} J_{\mathrm{H}, \mathrm{H}}=15.0,{ }^{3} J_{\mathrm{H}, \mathrm{H}}=5.0 \mathrm{~Hz}, 1 \mathrm{H}, \mathrm{CH}_{2} \mathrm{Ph}\right), 4.18(\mathrm{~d}$, ${ }^{3} J_{\mathrm{H}, \mathrm{H}}=8.7 \mathrm{~Hz}, 1 \mathrm{H}, \mathrm{CH}, 2$ '-H), $4.65\left(\mathrm{dd},{ }^{3} J_{\mathrm{H}, \mathrm{H}}=12.5,5.0 \mathrm{~Hz}, 1 \mathrm{H}, \mathrm{CH}, 2-\mathrm{H}\right), 5.71$ (br. d, $\left.{ }^{3} J_{\mathrm{H}, \mathrm{H}}=8.7 \mathrm{~Hz}, 1 \mathrm{H}, \mathrm{NH}\right), 6.12$ (br. d, $\left.{ }^{3} J_{\mathrm{H}, \mathrm{H}}=7.6 \mathrm{~Hz}, 1 \mathrm{H}, \mathrm{NH}\right), 7.11-7.14(\mathrm{~m}, 2 \mathrm{H}, \mathrm{Ar}-\mathrm{H})$, 7.23-7.29 (m, $3 \mathrm{H}, \mathrm{Ar}-\mathrm{H}) .-{ }^{13} \mathrm{C} \mathrm{NMR}\left(75.5 \mathrm{MHz}, \mathrm{CDCl}_{3}\right.$, additional APT): $\delta=13.2\left(-, \mathrm{CH}_{2}\right.$, cPr-C), 14.7 (-, $\left.\mathrm{CH}_{2}, \mathrm{cPr}-\mathrm{C}\right), 27.9$ (+, $\left.3 \mathrm{CH}_{3}\right), 28.2\left(+, 3 \mathrm{CH}_{3}\right), 37.4\left(-, \mathrm{CH}_{2}, \mathrm{C}-3\right) .46 .9$ (+, $\mathrm{CH}, *), 53.4(+, \mathrm{CH}, *), 81.1\left(-, \mathrm{C}_{\text {quat }}, t \mathrm{Bu}\right), 82.7\left(-, \mathrm{C}_{\text {quat }}, t \mathrm{Bu}\right), 117.3(-, \mathrm{CN}), 127.1(+, \mathrm{CH}$, Ar-C), 128.4 (+, 2 CH, Ar-C), 129.4 (+, 2 CH, Ar-C), 135.6 (-, $\left.\mathrm{C}_{\text {quat }}, \operatorname{Ar}-\mathrm{C}\right), 170.2$ (-, C=O, $*), 170.7(-, \mathrm{C}=\mathrm{O}, *)$, two carbon atoms were not detectable at this temp. $-{ }^{13} \mathrm{C}$ NMR (75.5 MHz, $\left.\mathrm{C}_{2} \mathrm{D}_{2} \mathrm{Cl}_{4}, 10{ }^{\circ} \mathrm{C}\right): \delta=12.5\left(\mathrm{CH}_{2}, \mathrm{cPr}-\mathrm{C}\right), 13.9\left(\mathrm{CH}_{2}, \mathrm{cPr}-\mathrm{C}\right), 27.5\left(\mathrm{C}_{\text {quat }}\right), 27.7$ (3 $\left.\mathrm{CH}_{3}\right), 28.0\left(3 \mathrm{CH}_{3}\right), 37.4\left(\mathrm{CH}_{2}, \mathrm{C}-3\right), 47.1(\mathrm{CH}, *), 53.5(\mathrm{CH}, *), 81.1\left(\mathrm{C}_{\text {quat }}, t \mathrm{Bu}\right), 82.5\left(\mathrm{C}_{\text {quat }}\right.$, $t \mathrm{Bu}), 117.0(\mathrm{CN}), 126.9(\mathrm{CH}, \mathrm{Ar}-\mathrm{C}), 128.2$ (2 CH, Ar-C), $129.1(2 \mathrm{CH}, \mathrm{Ar}-\mathrm{C}), 135.7\left(\mathrm{C}_{\text {quat }}\right.$, 
Ar-C), $154.3\left(\mathrm{C}_{\text {quat }}, \operatorname{Ar}-\mathrm{C}\right), 169.8\left(\mathrm{C}=\mathrm{O},{ }^{*}\right), 170.2(\mathrm{C}=\mathrm{O}, *), 170.7(\mathrm{C}=\mathrm{O}, *) . \mathrm{MS}(\mathrm{EI}): m / z$ $(\%)=443(9)\left[\mathrm{M}^{+}\right], 387$ (10), 331 (28), 314 (30), 286 (22), 242 (10), 148 (100), 120 (85), 91 (15), 57 (40). $\mathrm{C}_{24} \mathrm{H}_{33} \mathrm{~N}_{3} \mathrm{O}_{5}$ (443.5): calcd. C 64.99, H 7.50, N 9.47; found C 64.76, H 7.76, N 9.60 .

The diastereoisomer $\left(2 \boldsymbol{S}, \mathbf{2}^{\prime} \boldsymbol{R}\right)-\mathbf{1 1 8}: \mathrm{R}_{\mathrm{f}}=0.27$, m.p. $142-143{ }^{\circ} \mathrm{C},[\alpha]_{D}^{20}=+22.5(c=0.16$ in<smiles>CCCCOC(=O)C(Cc1ccccc1)NC(=O)C1(C(C#N)NC(=O)OC(C)(C)C)CC1</smiles>
$\left.\mathrm{CHCl}_{3}\right) .-\mathrm{IR}(\mathrm{KBr}): \tilde{v}=3374 \mathrm{~cm}^{-1}, 3281,3036$, 2970, 2250, 1739, 1690, 1649, 1535, 1369. - ${ }^{1} \mathrm{H}$

NMR $\left(250 \mathrm{MHz}, \mathrm{CDCl}_{3}\right): \delta=0.99-1.26(\mathrm{~m}, 4 \mathrm{H}$, cPr-H), $1.43\left(\mathrm{~s}, 9 \mathrm{H}, 3 \mathrm{CH}_{3}\right), 1.46\left(\mathrm{~s}, 9 \mathrm{H}, 3 \mathrm{CH}_{3}\right), 3.04\left(\mathrm{dd},{ }^{2} J_{\mathrm{H}, \mathrm{H}}=12.5,{ }^{3} J_{\mathrm{H}, \mathrm{H}}=5.0 \mathrm{~Hz}, 1 \mathrm{H}\right.$, $\left.\mathrm{CH}_{2} \mathrm{Ph}\right), 3.12\left(\mathrm{dd},{ }^{2} J_{\mathrm{H}, \mathrm{H}}=12.5,{ }^{3} J_{\mathrm{H}, \mathrm{H}}=7.5 \mathrm{~Hz}, 1 \mathrm{H}, \mathrm{CH}_{2} \mathrm{Ph}\right), 4.10\left(\mathrm{~d},{ }^{3} J_{\mathrm{H}, \mathrm{H}}=10.0 \mathrm{~Hz}, 1 \mathrm{H}\right.$, $\left.\mathrm{CH}, 2^{\prime}-\mathrm{H}\right), 4.71\left(\mathrm{dd},{ }^{3} J_{\mathrm{H}, \mathrm{H}}=12.5,5.0 \mathrm{~Hz}, 1 \mathrm{H}, \mathrm{CH}, 2-\mathrm{H}\right), 5.67$ (br. d, ${ }^{3} J_{\mathrm{H}, \mathrm{H}}=10.0 \mathrm{~Hz}, 1 \mathrm{H}$, NH), 6.15 (br. d, $\left.{ }^{3} J_{\mathrm{H}, \mathrm{H}}=12.5 \mathrm{~Hz}, 1 \mathrm{H}, \mathrm{NH}\right), 7.06-7.10$ (m, $\left.2 \mathrm{H}, \mathrm{Ar}-\mathrm{H}\right), 7.24-7.31$ (m, $3 \mathrm{H}$, Ar-H). $-{ }^{13} \mathrm{C}$ NMR (75.5 MHz, additional APT): $\delta=13.3\left(-, \mathrm{CH}_{2}, \mathrm{cPr}-\mathrm{C}\right), 14.7\left(-, \mathrm{CH}_{2}, \mathrm{cPr}-\right.$ C), $27.9\left(+, 3 \mathrm{CH}_{3}\right), 28.2\left(+, 3 \mathrm{CH}_{3}\right), 37.7\left(-, \mathrm{CH}_{2}, \mathrm{C}-3\right), 47.1(+, \mathrm{CH}, *), 53.3(+, \mathrm{CH}, *)$, $81.1\left(-, \mathrm{C}_{\text {quat }}, t \mathrm{Bu}\right), 83.0\left(-, \mathrm{C}_{\text {quat }}, t \mathrm{Bu}\right), 117.5(-, \mathrm{CN}), 127.1(+, \mathrm{CH}, \mathrm{Ar}-\mathrm{C}), 128.4(+, 2 \mathrm{CH}$, Ar-C), 129.4 (+, 2 CH, Ar-C), 135.8 (-, $\left.\mathrm{C}_{\text {quat }}, \operatorname{Ar}-\mathrm{C}\right), 170.2$ (-, C=O, *), $170.3(-, \mathrm{C}=\mathrm{O}, *)$, two carbon atoms were not detectable at this temp. ${ }^{13} \mathrm{C}$ NMR $\left(75.5 \mathrm{MHz}, \mathrm{C}_{2} \mathrm{D}_{2} \mathrm{Cl}_{4}, 100{ }^{\circ} \mathrm{C}\right)$ : $\delta=12.5\left(\mathrm{CH}_{2}, \mathrm{cPr}-\mathrm{C}\right), 13.9\left(\mathrm{CH}_{2}, \mathrm{cPr}-\mathrm{C}\right), 27.6\left(\mathrm{C}_{\text {quat }}\right), 27.7\left(3 \mathrm{CH}_{3}\right), 28.0\left(3 \mathrm{CH}_{3}\right), 37.7\left(\mathrm{CH}_{2}\right.$, C-3), $47.1(\mathrm{CH}), 53.4(\mathrm{CH}), 81.1\left(\mathrm{C}_{\text {quat }}, t \mathrm{Bu}\right), 82.7\left(\mathrm{C}_{\text {quat }}, t \mathrm{Bu}\right), 117.0(\mathrm{CN}), 126.8(\mathrm{CH}, \mathrm{Ar}-\mathrm{C})$, 128.2 (2 CH, Ar-C), 129.1 (2 CH, Ar-C), 135.8 (Ar-C), 154.3 ( $\left.\mathrm{C}_{\text {quat }}, \mathrm{Ar}-\mathrm{C}\right), 169.9$ (C=O, *), $170.1(\mathrm{C}=\mathrm{O}, *) .-\mathrm{MS}(\mathrm{EI}): m / z(\%)=443$ (38), 387 (35), 331 (75), 314 (65), 286 (68), 240 (25), 184 (22), 148 (100), 120 (55), 57 (50). $-\mathrm{C}_{24} \mathrm{H}_{33} \mathrm{~N}_{3} \mathrm{O}_{5}$ (443.5): calcd. C 64.99, H 7.50, N 9.47; found C 64.77, H 7.62, N 9.42.

Methyl 1-(Benzoylaminophenylmethyl)-cyclopropane carboxylate (123): In argon<smiles>COC(=O)C1(C(NC(=O)c2ccccc2)c2ccccc2)CC1</smiles>
atmosphere trimethylsilylchloride $(0.37 \mathrm{~mL}, 2.92 \mathrm{mmol})$ was added to a stirred solution of 53a $(0.325 \mathrm{~g}, 1.17 \mathrm{mmol})$ in $\mathrm{MeOH}(30 \mathrm{~mL})$. The mixture was refluxed for 24 hours. After cooling to room temperature, $\mathrm{CH}_{2} \mathrm{Cl}_{2}(60 \mathrm{~mL})$ was added and the resulting solution was washed with $\mathrm{NaHCO}_{3}$ solution $(2 \times 50 \mathrm{~mL})$. The organic phase was dried over $\mathrm{MgSO}_{4}$ and after filtration and evaporation of the solvent under reduced pressure, the crude residue was purified by column cromatography $\left(R_{\mathrm{f}}=0.26,25 \mathrm{~g}\right.$ of silica gel, $2 \times 15 \mathrm{~cm}$ column, hexane/Et $\left.\mathrm{Et}_{2} \mathrm{O}: 1\right)$ and gave $123(0.148 \mathrm{~g}, 41 \%)$ as a colorless solid, 
m.p. $139-140{ }^{\circ} \mathrm{C}$. - IR (film): $\tilde{v}=3340 \mathrm{~cm}^{-1}, 3033,2959,1734,1717,1635,1521,1313$, 1140. $-{ }^{1} \mathrm{H}$ NMR $\left(250 \mathrm{MHz}, \mathrm{CDCl}_{3}\right): \delta=1.09-1.28$ (m, $\left.3 \mathrm{H}, \mathrm{cPr}-\mathrm{H}\right), 1.61-1.70(\mathrm{~m}, 1 \mathrm{H}, \mathrm{cPr}-$ $\mathrm{H}), 3.57\left(\mathrm{~s}, 3 \mathrm{H}, \mathrm{OCH}_{3}\right), 4.83-4.88\left(\mathrm{~d},{ }^{3} J_{\mathrm{H}, \mathrm{H}}=9.2 \mathrm{~Hz}, 1 \mathrm{H}, \mathrm{CH}\right), 7.18-7.29(\mathrm{~m}, 3 \mathrm{H}, \mathrm{Ar}-\mathrm{H})$, 7.35-7.47 (m, 5 H, Ar-H), 7.80-7.89 (m, 4 H, 3 Ar-H and NH). $-{ }^{13} \mathrm{C}$ NMR $(50.3 \mathrm{MHz}$, $\mathrm{CDCl}_{3}$, additional APT): $\delta=15.2\left(-, \mathrm{CH}_{2}, \mathrm{cPr}-\mathrm{C}\right), 16.1\left(-, \mathrm{CH}_{2}, \mathrm{cPr}-\mathrm{C}\right), 27.7\left(-, \mathrm{C}_{\text {quat }}\right), 52.0$ $(+, *), 56.6(+, *), 126.6(+, 2 \mathrm{CH}, \mathrm{Ar}-\mathrm{C}), 127.1(+, 2 \mathrm{CH}, \mathrm{Ar}-\mathrm{C}), 127.3(+, \mathrm{CH}, \mathrm{Ar}-\mathrm{C}), 128.4$ (+, 2 CH, Ar-C), 128.6 (+, 2 CH, Ar-C), 131.6 (+, CH, Ar-C), 134.3 (-, C quat, Ar-C), 140.3 (-, $\left.\mathrm{C}_{\text {quat, }}, \mathrm{Ar}-\mathrm{C}\right), 166.5(-, \mathrm{C}=\mathrm{O}, *), 174.7(-, \mathrm{C}=\mathrm{O}, *) .-\mathrm{MS}(\mathrm{EI}): m / z(\%)=309$ (18), $276(25)$, 250 (10), 204 (92), 105 (100), 77 (40). 


\subsection{Synthesis of Compounds in Chapter 5}

5-aza-spiro[2.3]hexan-4-one (128): To a solution of $\mathbf{5 3 g}(0.178 \mathrm{~g}, 0.82 \mathrm{mmol})$ in acetonitrile<smiles>O=C1NCC12CC2</smiles>
$(10.5 \mathrm{~mL})$ was slowly added a solution of ceric ammonium nitrate (CAN) $(0.877 \mathrm{~g}, 1.60 \mathrm{mmol})$ in water $(3.5 \mathrm{~mL})$ at room temperature. After $1 \mathrm{~h}$ additional CAN $(0.438 \mathrm{~g}, 0.80 \mathrm{mmol})$ was added in portions. After additional 30 minutes the reaction was stopped and water $(50 \mathrm{~mL})$ and ethyl acetate $(50 \mathrm{~mL})$ were added into the reaction flask. The two phases were separated and the water extracted were washed with ethyl acetate $(3 \times 50 \mathrm{~mL})$. The organic layers were than washed with a solution of $\mathrm{NaHCO}_{3}$ and then dried over $\mathrm{MgSO}_{4}$. After filtration and evaporation of the solvent under reduced pressure, the crude product was purified by column cromatography $\left(R_{\mathrm{f}}=0.12,15 \mathrm{~g}\right.$ of silica gel, $2 \times 8 \mathrm{~cm}$ column, hexane/ $\left./ \mathrm{Et}_{2} \mathrm{O} 1: 6\right)$ to give 128 (26.0 mg, 33\%) as a colorless oil. ${ }^{1} \mathrm{H}$ NMR $\left(250 \mathrm{MHz}, \mathrm{CDCl}_{3}\right): \delta=0.87-1.11(\mathrm{~m}, 2 \mathrm{H}, \mathrm{cPr}-$ $\mathrm{H}), 1.16-1.28(\mathrm{~m}, 2 \mathrm{H}, \mathrm{cPr}-\mathrm{H}), 3.43-3.45\left(\mathrm{~d},{ }^{3} \mathrm{~J}_{\mathrm{H}, \mathrm{H}}=5.0 \mathrm{~Hz}, 2 \mathrm{H}, \mathrm{CH}_{2}\right), 7.09$ (bs, NH). $-{ }^{13} \mathrm{C}$ NMR (50.3 MHz, $\left.\mathrm{CDCl}_{3}\right): \delta=8.2\left(2 \mathrm{CH}_{2}, \mathrm{cPr}-\mathrm{C}\right), 31.5\left(\mathrm{C}_{\text {quat }}, \mathrm{C}-3\right), 48.2\left(\mathrm{CH}_{2}, \mathrm{C}-6\right), 172.5$ $(\mathrm{C}=\mathrm{O}, \mathrm{C}-4)$.

\section{Cyclization of Methyl 1-(aminomethyl)-cyclopropane carboxylate 130. 5-aza-} spiro[2.3]hexan-4-one (128): A solution of $130(0.258 \mathrm{~g}, 2.00 \mathrm{mmol})$ in THF (6 mL) was added at $0{ }^{\circ} \mathrm{C}$ to a solution of LDA $(0.42 \mathrm{~mL}, 0.304 \mathrm{~g}, 3.00 \mathrm{mmol}$ of diisopropylamine $)$ in $\mathrm{THF} /$ hexane $(10 \mathrm{~mL})$. The resulting mixture was stirred at $25^{\circ} \mathrm{C}$, overnight. The mixture was diluted with a $1.0 \mathrm{M}$ sol. of $\mathrm{NH}_{4} \mathrm{Cl}(20 \mathrm{~mL})$ and extracted with $\mathrm{CH}_{2} \mathrm{Cl}_{2}(2 \times 20 \mathrm{~mL})$. The organic layers were then dried over $\mathrm{Na}_{2} \mathrm{SO}_{4}$. Column cromatography of the residue obtained after filtration and evaporation of the solvent $\left(R_{\mathrm{f}}=0.1,15 \mathrm{~g}\right.$ of silica gel, $2 \times 10 \mathrm{~cm}$ column, $\mathrm{MeOH} / \mathrm{Et}_{2} \mathrm{O}$ 1:6) gave 128 (40.0 mg, 21\%).

Cyclization of 130·HCl. 5-aza-spiro[2.3]hexan-4-one (128): To a solution of $130 \cdot \mathrm{HCl}$ $(0.564 \mathrm{~g}, 3.40 \mathrm{mmol})$ in $\mathrm{CH}_{2} \mathrm{Cl}_{2}$ was added $\mathrm{LiOH}(3.6 \mathrm{~mL}$ of a $1.0 \mathrm{M}$ solution) in water $(20 \mathrm{~mL})$ at $0{ }^{\circ} \mathrm{C}$. The mixture was stirred for additional $2 \mathrm{~h}$ at $25^{\circ} \mathrm{C}$. The two phases were separated and the organic layers were dried over $\mathrm{Na}_{2} \mathrm{SO}_{4}$. After filtration and evaporation of the solvent, the residue obtained $(0.335 \mathrm{~g}, 2.59 \mathrm{mmol})$ was solved in diethyl ether $(40 \mathrm{~mL})$ and added in 4 hours to a solution of EtMgBr $(1.2 \mathrm{~mL}$ of a $3.20 \mathrm{M} \mathrm{sol}$., $3.84 \mathrm{mmol})$ in diethyl ether $(160.0 \mathrm{~mL})$. The mixture was stirred overnight at room temperature. A solution of $\mathrm{NH}_{4} \mathrm{Cl}$ sat. $(200 \mathrm{~mL})$ was added and the two phases separated. The water phase was washed 
with $\mathrm{CH}_{2} \mathrm{Cl}_{2}(2 \times 60 \mathrm{~mL})$ and the combined organic layers dried over $\mathrm{Na}_{2} \mathrm{SO}_{4}$. Just traces of $128(15.0 \mathrm{mg}, 6 \%)$ were obtained after evaporation of the solvent.

Methyl 1-(\{[tert-Butoxycarbonyl]amino\}methyl)cyclopropane-1-carboxylate (131): To a suspension of $130 \cdot \mathrm{HCl}(0.828 \mathrm{~g}, 5.00 \mathrm{mmol})$ in acetonitrile $(5 \mathrm{~mL})$ were added at $25^{\circ} \mathrm{C}$ triethylamine $(0.70 \mathrm{~mL}, 0.506 \mathrm{~g}, 5.00 \mathrm{mmol})$ and in 20 minutes a solution of $\mathrm{Boc}_{2} \mathrm{O}(1.09 \mathrm{~g}$, $5.00 \mathrm{mmol})$ in acetonitrile $(5 \mathrm{~mL})$. After 3 hours no more starting material was observed in the mixture and diethyl ether $(20 \mathrm{~mL})$ and $\mathrm{NaHCO}_{3}(20 \mathrm{~mL})$ were added to the flask. The two phases were separated and the water phase was washed with ether $(3 \times 10 \mathrm{~mL})$. The combined organic layers dried over $\mathrm{MgSO}_{4}$ and then filtered. Evaporation of the solvent gave 131 $(1.13 \mathrm{~g}, 98 \%)$.

1-(\{[tert-Butoxycarbonyl]amino\}methyl)cyclopropane-1-carboxylic acid (134): A solution of $\mathrm{LiOH}(0.599 \mathrm{~g}, 2.50 \mathrm{mmol})$ in water $(8 \mathrm{~mL})$ was dropped to a solution of $131(1.10 \mathrm{~g}$, $5.00 \mathrm{mmol})$ in $\mathrm{MeOH}(6 \mathrm{~mL})$, mantained at $0{ }^{\circ} \mathrm{C}$. The mixture was left under stirring for 20 hours at room temperature. After evaporating $\mathrm{MeOH}$ in vacuo water $(20 \mathrm{~mL})$ was added to the flask and the $\mathrm{pH}$ turned to 4 , with a $0.02 \mathrm{M}$ solution of $\mathrm{HCl}$. The water phase was extracted with ether $(3 \times 30 \mathrm{~mL})$. The organic layers were dried over $\mathrm{MgSO}_{4}$. Filtration and evaporation of the solvent to dryness gave 134 (0.939 g, 87\%).

1-(Aminomethyl)-cyclopropane carboxylic acid trifluoroacetate (135-TFA): Trifluoroacetic acid (1.243 g, $0.84 \mathrm{~mL}, 10.9 \mathrm{mmol})$ was added at room temperature to a suspension of $134(0.216 \mathrm{~g}, 1.0 \mathrm{mmol})$ and $\mathrm{iPr}_{3} \mathrm{SiH}(0.458 \mathrm{~g}, 0.59 \mathrm{~mL}, 2.9 \mathrm{mmol})$ in dry $\mathrm{CH}_{2} \mathrm{Cl}_{2}(3 \mathrm{~mL})$. After 1.5 hours the solvent was removed in vacuo and TFA was removed, adding toluene and evaporating to dryness $(3 \times 5 \mathrm{~mL})$. 135 TFA was obtained in quantitative yield $(0.229 \mathrm{~g})$.

Attempt of Ring Closure of 135 TFA with Coupling Reagents: To a solution of $135 \cdot \mathrm{TFA}$ $(0.229 \mathrm{~g}, 1.00 \mathrm{mmol})$ in $\mathrm{CH}_{2} \mathrm{Cl}_{2}: \mathrm{DMF}=6: 1(43 / 7 \mathrm{~mL})$ mantained at $0{ }^{\circ} \mathrm{C}$, were added DIPEA (0.646 g, $0.85 \mathrm{~mL}, 5.00 \mathrm{mmol})$, EDCI (0.287 g, $1.50 \mathrm{mmol})$, HOAt (0.204 g, $1.50 \mathrm{mmol})$. By adding the last reagent the solution turned to a fine suspension. After 12 hours at $0{ }^{\circ} \mathrm{C}$ the solution was washed with $\mathrm{NaHSO}_{4}(10 \%$ sol. $)(6 \times 20 \mathrm{~mL})$. The organic phase was dried over $\mathrm{MgSO}_{4}$. No trace of the cyclization product was found in the NMR spectrum, measured after evaporation of the solvent. 
Benzylic protection of Methyl 1-(aminomethyl)-cyclopropane carboxylate hydrochloride $(130 \cdot \mathrm{HCl})$. General Procedure 10

(GP 10): To a solution of $\mathbf{1 3 0} \cdot \mathbf{H C l}$ (1 equiv.) and triethylamine (1 equiv.) in $\mathrm{MeOH}$, was added the aldehyde (1.5 equiv.) and the mixture was stirred for 1.5 hours. $\mathrm{NaBH}_{4}$ (2 equiv.) was added in portions in 1 hour. After 1 night at $25^{\circ} \mathrm{C}$ the solvent was evaporated in vacuo, water and AcOEt were added. After separation, the water phase was washed with AcOEt and the organic layers dried over $\mathrm{Na}_{2} \mathrm{SO}_{4}$.

Methyl 1-(Benzylamino-methyl)-cyclopropane carboxylate (138): Column cromatography<smiles>COC(=O)C1(CNCc2ccccc2)CC1</smiles>
$\left(R_{\mathrm{f}}=0.17,30 \mathrm{~g}\right.$ of silica gel, $3 \times 8 \mathrm{~cm}$ column, hexane $/ \mathrm{Et}_{2} \mathrm{O}$ $1: 3)$ of the residue obtained from $\mathbf{1 3 0} \cdot \mathbf{H C l}(0.497 \mathrm{~g}$, $3.00 \mathrm{mmol})$, triethylamine $(0.304 \mathrm{~g}, 0.40 \mathrm{~mL}, 3.00 \mathrm{mmol})$, $\mathrm{NaBH}_{4}(0.227 \mathrm{~g}, 6.00 \mathrm{mmol})$ in $\mathrm{MeOH}(7 \mathrm{~mL})$, under the GP 10 gave $138(0.580 \mathrm{~g}, 88 \%)$ as a colorless oil. - IR (film): $\tilde{v}=3333 \mathrm{~cm}^{-1}, 3086,2951,2848,1718,1454,1437 .-{ }^{1} \mathrm{H}$ NMR (200 MHz, $\left.\mathrm{CDCl}_{3}\right): \delta=0.74-0.79(\mathrm{~m}, 2 \mathrm{H}, \mathrm{cPr}-\mathrm{H}), 1.22-1.25(\mathrm{~m}, 2 \mathrm{H}, \mathrm{cPr}-\mathrm{H}), 2.68$ (s, $2 \mathrm{H}$, $\left.\mathrm{CH}_{2}\right), 3.63\left(\mathrm{~s}, 3 \mathrm{H}, \mathrm{OCH}_{3}\right), 3.79\left(\mathrm{~s}, 2 \mathrm{H}, \mathrm{NCH}_{2} \mathrm{Ph}\right), 7.19-7.31(\mathrm{~m}, 5 \mathrm{H}, \mathrm{Ar}-\mathrm{H}) .-{ }^{13} \mathrm{C} \mathrm{NMR}$ $\left(50.3 \mathrm{MHz}, \mathrm{CDCl}_{3}\right.$, additional APT): $\delta=14.9\left(-, 2 \mathrm{CH}_{2}, \mathrm{cPr}-\mathrm{C}\right), 23.8\left(-, \mathrm{C}_{\text {quat }}\right), 51.7(+$, $\left.\mathrm{OCH}_{3}\right), 52.6\left(-, \mathrm{CH}_{2},{ }^{*}\right), 53.6\left(-, \mathrm{CH}_{2},{ }^{*}\right), 126.8(+, \mathrm{CH}, \mathrm{Ar}-\mathrm{C}), 127.9$ (+, $\left.2 \mathrm{CH}, \mathrm{Ar}-\mathrm{C}\right), 128.3$ $(+, 2 \mathrm{CH}, \operatorname{Ar}-\mathrm{C}), 140.2\left(-, \mathrm{C}_{\text {quat }}, \mathrm{Ar}-\mathrm{C}\right), 175.3(-, \mathrm{C}=\mathrm{O}) .-\mathrm{MS}(\mathrm{EI}): \mathrm{m} / \mathrm{z}(\%)=218$ (2), 204 (5), 128 (25), 120 (10), 106 (100), 96 (18), 91 (90), 65 (10). - $\mathrm{C}_{13} \mathrm{H}_{17} \mathrm{NO}_{2}$ (219.28): calcd. C 71.21, H 7.81, N 6.39; found C 70.96, H 7.75, N 6.17.

Methyl 1-[(p-Methoxybenzylamino)-methyl]-cyclopropane carboxylate (139): Column<smiles>COC(=O)C1(CNCc2ccc(OC)cc2)CC1</smiles>
cromatography $\left(R_{\mathrm{f}}=0.12,50 \mathrm{~g}\right.$ of silica gel, $3 \times 15 \mathrm{~cm}$ column, hexane/ $\operatorname{Et}_{2} \mathrm{O} 1: 3$ ) of the residue obtained from 130.HCl $(0.828 \mathrm{~g}, 5.00 \mathrm{mmol})$, triethylamine $(0.506 \mathrm{~g}$, $0.70 \mathrm{~mL}, 5.00 \mathrm{mmol}), \mathrm{NaBH}_{4}(0.378 \mathrm{~g}, 10.0 \mathrm{mmol})$ in $\mathrm{MeOH}(8 \mathrm{~mL})$, under the GP 10 gave $139(1.20 \mathrm{~g}, 96 \%)$ as a colorless oil. - IR (film): $\tilde{v}=3331 \mathrm{~cm}^{-1}, 3005,2951,2835,1721,1611,1585,1512,1437 .-{ }^{1} \mathrm{H}$ NMR $(200 \mathrm{MHz}$, $\left.\mathrm{CDCl}_{3}\right): \delta=0.74-0.77(\mathrm{~m}, 2 \mathrm{H}, \mathrm{cPr}-\mathrm{H}), 1.20-1.24(\mathrm{~m}, 2 \mathrm{H}, \mathrm{cPr}-\mathrm{H}), 2.18\left(\mathrm{~s}, 2 \mathrm{H}, \mathrm{CH}_{2}\right), 2.66$ (s, $\left.3 \mathrm{H}, \mathrm{OCH}_{3}\right), 3.72\left(\mathrm{~s}, 2 \mathrm{H}, \mathrm{NCH}_{2} \mathrm{Ph}\right), 3.76$ (s, $\left.3 \mathrm{H}, \mathrm{OCH}_{3}\right), 6.81-6.84$ (m, $\left.2 \mathrm{H}, \mathrm{Ar}-\mathrm{H}\right), 7.20-$ $7.24(\mathrm{~m}, 2 \mathrm{H}, \mathrm{Ar}-\mathrm{H}) .-{ }^{13} \mathrm{C} \mathrm{NMR}\left(50.3 \mathrm{MHz}, \mathrm{CDCl}_{3}\right.$, additional APT): $\delta=14.9\left(-, 2 \mathrm{CH}_{2}\right.$, cPr-C), $23.8\left(-, \mathrm{C}_{\text {quat }}\right), 51.7\left(+, \mathrm{CH}_{3},{ }^{*}\right), 52.5\left(-, \mathrm{CH}_{2},{ }^{*}\right), 53.0\left(-, \mathrm{CH}_{2}, *\right), 55.2\left(+, \mathrm{CH}_{3}, *\right)$, 
113.7 (+, 2 CH, Ar-C), 129.1 (+, 2 CH, Ar-C), 132.2 (-, C quat, Ar-C), 158.5 (-, C quat $_{\text {, }}$ Ar-C), 175.3 (-, C=O). - MS (EI): m/z (\%)=248 (5), 136 (100), 121 (88), 96 (5), 78 (8), 41 (2). $\mathrm{C}_{14} \mathrm{H}_{19} \mathrm{NO} 3$ (249.31): calcd. C 67.45, H 7.68, N 5.62; found C 67.55, H 7.83, N 5.56.

5-(p-Methoxybenzyl)-5-azaspiro[2.3]hexan-4-one (53g): Compound $139 \quad(0.625 \mathrm{~g}$, $2.50 \mathrm{mmol}$ ) was solved in $25 \mathrm{~mL} \mathrm{NaOH} 1.0 \mathrm{M}$ in methanol. The mixture was refluxed for $2 \mathrm{~h}$, When the starting material disappeared from the TLC, the mixture was cooled to room temperature and made neutral with a $0.5 \mathrm{~N} \mathrm{H}_{2} \mathrm{SO}_{4}$ solution: a solid precipitates and water was evaporated in vacuo. The solid obtained was solved in $\mathrm{CHCl}_{3}$ and dried over $\mathrm{Na}_{2} \mathrm{SO}_{4}$. After filtration and evaporation in vacuo of the solvent a colorless solid (1.12 g) was obtained. To a suspension of it in $\mathrm{CH}_{2} \mathrm{Cl}_{2}(250 \mathrm{~mL})$ were added 2-chloro- $N$-methyl-pyridinium iodide 140 $(0.703 \mathrm{~g}, 2.75 \mathrm{mmol})$ and triethylamine $(0.885 \mathrm{~g}, 1.20 \mathrm{~mL}, 8.75 \mathrm{mmol})$. The mixture was stirred at room temperature until the starting material disappeared from the TLC $(12 \mathrm{~h})$. Column cromatography of the residue obtained after evaporation of the solvent $\left(R_{\mathrm{f}}=0.28\right.$, 50 g silica gel, $3 \times 15 \mathrm{~cm}$ column, hexane/Et $2 \mathrm{O} 1: 3)$ gave $53 \mathrm{~g}(0.277 \mathrm{~g}, 51 \%)$.

Poly(3-Phenyl-2-azetidinone) (154): $\mathrm{LiCl}(0.140 \mathrm{~g}, 3.4 \mathrm{mmol})$ was first dried in vacuo at<smiles>O=C(CNC(=O)C(CNC(=O)c1ccccc1)C(=O)NCc1ccccc1)NCc1ccccc1</smiles>
$140{ }^{\circ} \mathrm{C}$ for 30 minutes in a schlenk flask. After cooling at room temperature, the monomer $\mathbf{1 4 8}$ $(1.00 \mathrm{~g}, 6.79 \mathrm{mmol})$ and the activator 149 (0.040 g, $0.160 \mathrm{mmol})$ were dissolved in DMF (3.40 mL) under nitrogen atmosphere. The base $t \mathrm{BuOK}(4.0 \mathrm{mg}, 0.034 \mathrm{mmol})$ was added and the mixtutre stirred for 30 minutes at $25^{\circ} \mathrm{C}$. Benzylamine $(98.0 \mathrm{mg}, 0.1 \mathrm{~mL}, 0.92 \mathrm{mmol})$ was then added and the mixture was stirred for additional $72 \mathrm{~h}$. When a mixture acetone $:$ water $=5: 1(10 \mathrm{~mL})$ was added, a white solid precipitated. The latter was collected by centrifugation and dried in vacuo. The white solid $(0.825 \mathrm{~g})$ obtained, had melting point $>260^{\circ} \mathrm{C}$. $-\mathrm{IR}(\mathrm{KBr}): \tilde{v}=3291 \mathrm{~cm}^{-1}, 3060,3028,1648$, 1528, 1494, 1452, 697. - MS (ESI) (+): m/z (\%) = 570 (20), 643 (20), 717 (20), 822 (60), 937 (20), 969 (100), 1011 (20), 1116 (80), 1158 (10), 1263 (40), 1306 (10), 1410 (20), 1558 (10) and MS (ESI) (-): m/z (\%) = 651 (20), 798 (80), 945 (100), 1092 (70), 1139 (30), 1240 (30), $1386(20), 1432(10)$.

Anionic Polymerization of 108: $\mathrm{LiCl}(0.014 \mathrm{~g}, 0.325 \mathrm{mmol})$ was first dried in vacuo at $130{ }^{\circ} \mathrm{C}$ for $3 \mathrm{~h}$ in a schlenk flask. A solution of $108(0.080 \mathrm{~g}, 0.650 \mathrm{mmol})$ in dry DMAA 
$(2.0 \mathrm{~mL})$ was added under nitrogen atmosphere. The activator $107 \mathrm{c}\left(4.00 \times 10^{-3} \mathrm{~g}\right.$, $0.016 \mathrm{mmol})$ and $t \mathrm{BuOK}\left(1.0 \times 10^{-3} \mathrm{~g}, 0.9 \times 10^{-5} \mathrm{mmol}\right)$ were added to the solution. After $1 \mathrm{~h}$ at $25^{\circ} \mathrm{C}$ benzylamine was added ( 1 drop) and the mixture stirred for additional $72 \mathrm{~h}$. The latter was poured in a mixture acetone : water $=5: 1$ and diethyl ether was added to obtain the precipitation of a solid, that was collected by centrifugation. The white solid was solved in 2,2,2-trifluoroethanol and then precipitated again. The solid was collected and dried in vacuo. $50.0 \mathrm{mg}$ of a colorless solid were obtained. The solid obtained had melting point $>260{ }^{\circ} \mathrm{C}$. IR $(\mathrm{KBr}): \tilde{v}=3604 \mathrm{~cm}^{-1}, 3273,3010,1754,1672,1530,1416,1351,1146$. The polymer was not soluble in the solvents suitable for a more detailed carachterization.

Anionic Polymerization of 128: $\mathrm{LiCl}(0.108 \mathrm{~g}, 2.55 \mathrm{mmol})$ was first dried in vacuo at $130{ }^{\circ} \mathrm{C}$ for $3 \mathrm{~h}$ in a schlenk flask. A solution of $128(0.124 \mathrm{~g}, 1.28 \mathrm{mmol})$ in dry DMAA (1.2 $\mathrm{mL})$ was added under nitrogen atmosphere. $t \mathrm{BuOK}\left(1.0 \times 10^{-3} \mathrm{~g}, 0.9 \times 10^{-5} \mathrm{mmol}\right)$ was added to the solution. After $1 \mathrm{~h}$ at $25^{\circ} \mathrm{C}$ benzylamine was added (1 drop) and the mixture stirred for additional $72 \mathrm{~h}$. The latter was poured in a mixture acetone : water $=5: 1$ and diethyl ether was added to obtain the precipitation of a solid, that was collected by centrifugation. The white solid is solved in 2,2,2-trifluoroethanol and then precipitated again. The solid is collected and dried in vacuo. $124.0 \mathrm{mg}$ of a colorless solid were obtained. The solid obtained had melting point $>260^{\circ} \mathrm{C}$. IR $(\mathrm{KBr}): \tilde{v}=3081 \mathrm{~cm}^{-1}, 3005,2934,1635,1576,1365,1203$. The polymer was not soluble in the solvents suitable for a more detailed carachterization. 


\section{Summary}

During the elaboration of this thesis, several differently substituted monocyclic 3-spirocyclopropanated- $\beta$-lactams 53, which are formally derived from the $\alpha$-cyclopropyl-modified $\beta$ alanine 41, have been prepared. The synthesis of these derivatives was achieved through the rearrangement of 4,5-dispirocyclopropanated isoxazolidines 47 in the presence of an acid. The compounds 47 were obtained by means of 1,3-dipolar cycloadditions of linear nitrones 44 on bicyclopropylidene (24). The 3-spirocyclopropanated $\beta$-lactams 53 have subsequently been introduced into oligopeptides, in which the presence of the small ring adjacent to the carbonyl function introduces a conformational lock.

In the first part of this work, the synthesis of nitrones $44 \mathbf{a}-\mathbf{j}$ was described. The derivatives 44d-g, and $\mathbf{i}$ were not yet known in the literature and were obtained in $68 \%$ up to quantitative yield. The 1,3-dipolar cycloadditions of 44a-f furnished the 4,5-dispirocyclopropanatedisoxazolidines $\mathbf{4 7 a - f}$ in $75 \%$ up to quantitative yield. The nitrone $\mathbf{4 4 g}$, which was proved to be unstable, gave the cycloadduct $\mathbf{4 7} \mathrm{g}$ in $21 \%$ yield. The rearrangement under acidic conditions of isoxazolidines 47a-e, using the methodology of Brandi et al., led to the desired monocyclic $\beta$-lactams 53a-e in 75 to $94 \%$ yields. The cycloadduct 70, derived from the cyclic nitrone $\mathbf{4 4 h}$, did not lead to a $\beta$-lactam, but furnished the $\beta$-spirocyclopropanated homoproline $\mathbf{7 2}$ in low yield (18\%).

Furthermore, a new one-pot procedure for the synthesis of the monocyclic $\beta$-lactam derivatives 53 was developed and optimized, applying microwave heating. In particular, the azaspiro[2.3] hexanones 53g,j, 53e-H,f-H, 77c-Et,f-Et and 77d-Me were prepared in 49 up to $78 \%$ yield by a three-component cascade reaction, in which a $N$-hydroxylamine salt $\mathbf{6 5} \cdot \mathbf{H C l}$, formaldehyde 66-H or an alkyl glyoxylate 73-alk and bicyclopropylidene (24) yielded the final products in the presence of sodium acetate. Attempts to apply this methodology to $\mathrm{N}$ methyl hydroxylamines 65g and $N$-aryl hydroxylamines $65 \mathbf{h}, \mathbf{i}$ were unsuccessful. In the case of cyclohexyl glyoxylate 73-cHex and orto-iodobenzaldehyde 76, different conditions were found to be necessary for the formation of $\beta$-lactams $77 \mathbf{c}$-cHex and 53e respectively. These compounds could only be obtained by a one-pot reaction, using the hydroxylamine in its free form and adding a strong protic acid.

It was subsequenly shown how it is possible to obtain selectively the cyclopropanated isoxazolidines $\mathbf{4 7 g}, \mathbf{j}, \mathbf{4 7 e - E t}$ and $\mathbf{8 1}$ (in 49 to $70 \%$ yields), or the corresponding piperidones 
49g,j and 85 (in 7 to $37 \%$ yield). In the absence of acids, but with the same components used in the microwave assisted one-pot synthesis of $\beta$-lactams $\mathbf{5 3}$, it was in fact possible to obtain these other two kinds of azaheterocycles, just varying the reaction parameters, time and temperature.

The preparation of $\beta$-lactams 107a,b, 110 and 111, protected at the nitrogen atom with electron-withdrawing groups, was undertaken to apply them in the peptide-synthesis. The derivatives 107a,b were obtained by oxidation of the benzylic methylene carbon in 53a,b. The derivatives 110 and 111 were prepared by deprotection-reprotection sequences through introduction of the Boc group on 108 and 109, obtained from 53d and 77d-Me. The $\beta$-lactam derivatives 107a and 110 were coupled with tert-butyl glycinate 102 and/or tert-butyl $(S)$ phenylalaninate 115 by $N$-nucleophilic ring-opening of the azetidinone nucleus to obtain the dipeptides 116-118 in 61 to $84 \%$ yields. The separation of the two diasteroisomers $\left(2 S, 2^{\prime} S\right)$ 118 and $\left(2 S, 2^{\prime} R\right)-\mathbf{1 1 8}$, and the analysis of the X-Ray crystal structure of one of them, allowed the assignment of the absolute configurations. The derivative $\mathbf{1 0 7} \mathbf{b}$, when treated with $\mathbf{1 0 2}$, did not undergo ring-opening reaction, but the coupling took place at the methoxycarbonyl function, to give $\mathbf{1 1 4}$ in 51\% yield. The ring opening of 53a, under strongly acidic conditions with methanol as an $O$-nucleophile, led to the compound 123.

In the final part of this project, a synthesis of $\mathbf{1 2 8}$ was carried out via ring-closing of cyclopropyl- $\beta$-alanine 130. This approach allowed to obtain 128 in reasonable yields only after benzylic protection of $\mathbf{1 3 0}$ to get 138 and 139. Subsequently, via ring-closure of 139, the para-methoxybenzyl protected $\beta$-lactam 53g was obtained and its deprotection led to the target $\beta$-lactam 128. The possibility to synthesize $N$-deprotected-3-spirocyclopropanated $\beta$ lactam derivatives like $\mathbf{1 0 8}$ or $\mathbf{1 2 8}$ furnished ideal starting materials, to try an anionic polymerization protocol in order to obtain spirocyclopropanated poly- $\beta$-propiolactams.

The anionic polymerization of $\mathbf{1 0 8}$ and $\mathbf{1 2 8}$ was performed, and white, high melting solids were obtained. The analysis of their IR spectra showed positive results, but the impossibility to dissolve the obtained solids, limited their further characterization by GPC or ESI mass spectrometry. Additionally, the new polymer 154 was prepared by anionic polymerization of the $\beta$-lactam 148, in the presence of 149 , as activator. 


\section{E. References}

[1] A. Fleming, Br. J. Exp. Pathol. 1929, 10, 226-229.

[2] E. P. Abraham, E. Chain, W. Baker, R. Robinson, Pen. Report No 103, 1943.

[3] D. Crowfoot, C. W. Bunn, B. W. Rogers-Low, A. Turner-Jones in The Chemistry of Penicillin, Princeton University Press, Princeton, New Jersey, 1949, p. 310.

[4] G. G. F. Newton, E. P. Abraham, Nature 1955, 175, 548.

[5] [a] R. B. Morin, M. Gorman, Chemistry and Biology of $\beta$-Lactam Antibiotics, Academic Press, New York 1982; [b] D. B. Boyd, Penicillins and Cephalosporins, Vol. 1, from Chemistry and Biology of $\beta$-Lactam Antibiotics, Academic Press, New York 1982; [c] R. B. Morin, M. Gorman, Nontraditional $\beta$-Lactam Antibiotics, Vol. 2, from Chemistry and Biology of $\beta$-Lactam Antibiotics, Academic Press, New York 1982; [d] R. B. Morin, M. Gorman, The Biology of $\beta$-Lactam Antibiotics, Vol. 3, from Chemistry and Biology of $\beta$-Lactam Antibiotics, Academic Press, New York 1982.

[6] [a] H.-W. Liu, C. T. Walsh in The Chemistry of the cyclopropyl group (Ed. Z. Rappoport), Wiley 1987, pp. 959-1021; [b] J. Salaün, Top. Curr. Chem. 2000, 207, 1-67.

[7] [a] D. B. Boyd Penicillins and Cephalosporins, Vol. 1, from Chemistry and Biology of $\beta$ Lactam Antibiotics, Academic Press, New York 1982, pp. 567-577; [b] N. C. Cohen Actual. Chim. (May 1983), 7; [c] M. Takasuka, J. Nishikawa, K. Tori J. Antibiot. 1982, 35, 1729-1733; [d] D. B. Boyd J. Med. Chem. 1983, 26, 1010-1013.

[8] N. F. Osborne, J. Chem. Soc. Perkin Trans. I 1982, 1435-1439.

[9] D. H. Shih, J. A. Fayter, B. G. Christensen, Tetrahedron Lett. 1984, 25, 1639-1642.

[10] C. U. Kim, P. F. Misco, B. Y. Luh, Heterocycles 1987, 26, 1193-1196. 
[11] M. Es-Sayed, T. Heiner, A. de Meijere, Synthesis 1993, 57-58.

[12] D.H. Shih, F. Baker, L. Cama, B. G. Christensen, Heterocycles 1984, 21, 29-40.

[13] [a] T. J. Barton, R. J. Rogido, Tetrahedron Lett. 1972, 3901-3902; [b] S. R. Fletcher, I. T. Kay, J. Chem. Soc., Chem. Commun. 1978, 903-904.

[14] B. Alcaide, P. Almendros, Synlett, 2002, 3, 381-393.

[15] [a] I. Ojima, S. Suga, R. Abe, Chem. Lett. 1980, 853-856; [b] I. Ojima, X. Qiu, J. Am. Chem. Soc. 1987, 109, 6537-6538; [c] I. Ojima, M. Zhao, T. Yamato, K. Nakahashi, M. Yamashita, R. Abe, J. Org. Chem. 1991, 56, 5263-5277; [d] B. Alcaide, P. Almendros, C. Aragoncillo, N. R. Salgado, J. Org. Chem. 1999, 64, 9596-9604; [e] B. Alcaide, N. R. Salgado, M. A. Sierra, Tetrahedron Lett. 1998, 39, 467-470; [f] B. Alcaide, Y. MartínCantalejo, J. Rodríguez-López, M. A. Sierra, J. Org. Chem. 1993, 58, 4767-4770; [g] B. Alcaide, P. Almendros, N. R. Salgado, A. Rodríguez-Vicente, J. Org. Chem. 2000, 65, 4453-4455; [h] F. P. Cossío, C. Lopez, M. Oiarbide, C. Palomo, D. Aparicio, G. Rubiales, Tetrahedron Lett. 1988, 29, 3133-3136; [i] C. Palomo, M. Oiarbide, A. Landa, A. Esnal, A. Linden, J. Org. Chem. 2001, 66, 4180-4186.

[16] I. Ojima, F. Delaloge, Chem. Soc. Rev. 1997, 26, 377-386.

[17] F. Graupner, Dissertation, Universität Göttingen, 1993.

[18] The preparation and chemical transformations of methylenecyclopropane (43) and its close relative bicyclopropylidene (24) have been reviewed extensively. [a] P. Binger, H. M. Büch, Top. Curr. Chem. 1987, 135, 77-151; [b] P. Binger, T. Schmidt, in Houben-Weyl, Methods of Organic Chemistry, (Ed.: A. de Meijere) Vol. E 17c, Thieme, Stuttgart, 1997, pp. 2217-2294; [c] A. Brandi, A. Goti, Chem. Rev. 1998, 98, 589-635; [d] A. de Meijere, S. I. Kozhushkov, A. F. Khlebnikov, Zh. Org. Khim. 1996, 32, 1607-1626; Russ. J. Org. Chem. (Engl. Transl.) 1996, 32, 1555-1575; [e] A. de Meijere, S. I. Kozhushkov, A. F. Khlebnikov, Top. Curr. Chem. 2000, 207, 89-147; [f] A. de Meijere, S. I. Kozhushkov, T. Späth, M. von 
Seebach, S. Löhr, H. Nüske, T. Pohlmann, M. Es-Sayed, S. Bräse, Pure Appl. Chem. 2000, $72,1745-1756$.

[19] W. Weber, I. Erden, A. de Meijere, Angew. Chem. Int. Ed. Engl. 1980, 19, 387-388.

[20] I. Nakamura, T. Nemoto, A. de Meijere, Y. Yamamoto, Angew. Chem. 2005, to be submitted.

[21] F. Gnad, O. Reiser, Chem. Rev. 2003, 103, 1603-1623.

[22] S. Teichmann, Dissertation, Universität Hamburg, 1988.

[23] A. de Meijere, S. Teichmann, D. Yu, J. Kopf, M. Oly, N. von Thienen, Tetrahedron 1989, 45, 2957-2968.

[24] C. Palomo, J. M. Aizpurua, I. Ganboa, Chapter 14 in Enantioselective Synthesis of $\beta$ Amino Acids (Ed.: E. Juaristi), Wiley-VCH, New York, 1997, p. 279.

[25] M. S. Manhas, S. G. Amin, A. K. Bose, Heterocycles 1976, 5, 669-690.

[26] [a] J. M. Waisvizs, M. G. van der Hoeven, B. te Nijenhuis, J. Am. Chem. Soc. 1957, 79, 4524-4527; [b] K. S. Chu, G. R. Negrete, J. P. Konopelski, J. Org. Chem. 1991, 56, $5196-5206$.

[27] [a] Stachowiak, M. C. Khosla, K. Plucinska, F. M. Bumpus, J. Med. Chem. 1979, 22, 1128-1130; [b] T. Jamazaki, A. Probstl, P. Schiller, M. Goodman, Int. J. Pept. Protein Res. 1991, 37, 364-381; [c] Z. Huang, A. Probstl, J. R. Spencer, T. Yamazaki, M. Goodman, Int. J. Pept. Protein Res. 1993, 42, 352-365; [d] D. H. Appella, L. A. Christianson, D. A. Klein, D. R. Powell, X. Huang, J. J. Barchi, S. H. Gellman, Nature 1997, 387, 381-384; [e] S. H. Gellman, Acc. Chem. Res. 1998, 31, 173-180; [f] E. A. Porter, X. Wang, H. Lee, B. Weisblum, S. H. Gellman, Nature 2000, 404, 565; [g] D. Seebach, M. Overhand, F. N. M. Kühnle, B. Martinoni, L. Oberer, U. Hommel, H. Widmer, Helv. Chim. Acta 1996, 79, 913-941; [h] S. Abele, G. Guichard, D. Seebach, Helv. Chem. Acta 1998, 81, 2141-2156; [i] 
K. Gademann, M. Ernst, D. Hoyer, D. Seebach, Angew. Chem. 1999, 111, 1302-1304; Angew. Chem., Int. Ed. 1999, 38, 1223-1226; [j] B. W. Gung, D. Zou, A. M. Stalcup, C. E. Cottrell, J. Org. Chem. 1999, 64, 2176-2177; [k] Y. Hamuro, J. P. Schneider, W. F. DeGrado, J. Am. Chem. Soc. 1999, 121, 12200-12201.

[28] [a] N. Katayama, Y. Nozaki, S. Tsubotani, M. Kondo, S. Harada, H. Ono, J. Antibiot. 1990, 33, 1128-1137; [b] J. N. Denis, A. E. Greene, D. Guenard, F. Gueritte-Voegelein, L. Mangatal, P. Potier, J. Am. Chem. Soc. 1988, 110, 5917-5919; [c] H. Umezawa, T. Aoyagi, H. Suda, M. Hamada, T. Takeuchi, J. Antibiot. 1976, 29, 97.

[29] K. Iizuka, H. Harada, K. Akahane, T. Kubota, H. Umeyawa, Y. J. Kiso, J. Chem. Soc. Chem. Commun. 1989, 1678-1680;

[30] S. Abele, P. Seiler, D. Seebach, Helv. Chem. Acta 1999, 82, 1559-1571.

[31] [a] H. G. Richey Jr chapter 25 in, Carbonium Ions Eds. G. A. Olah and P. v. R. Schleyer, Wiley-Interscience. New York, 1972, Vol. III; [b] A. D. Walsh, Trans. Faraday Soc. 1949, 45, 179-190; [c] T. M. Sugden, Nature 1947, 160, 367-368; [d] S. A. Monti, J. Org. Chem. 1970, 35, 380-383; [e] A. de Meijere, Angew. Chem. 1979, 11, 867-884; Angew. Chem. Int. Ed. 1979, 18, 809-826; [f] Z. Rappoport in The Chemistry of the Cyclopropyl group, John Wiley \& Sons, Chichester, 1987, Vol. 2; [g] F. H. Allen, Acta Crystallogr., Sect. B 1980, 36, 81; [h] M. Pellissier, A. Serafini, J. Devanneaux, J.-F. Labarre, J.-F. Tocanne, Tetrahedron 1971, 27, 3271-3284; [i] J. -F. Tocanne, Tetrahedron 1972, 28, 389-416.

[32] [a] A. Brandi, F. M. Cordero, A. Goti, F. De Sarlo, A. Guarna, Synlett 1993, 1-8; [b] F. M. Cordero, F. De Sarlo, A. Brandi, Monatsh. Chem. 2004, 135, 649-669.

[33] A. Hassner, C. Stumer, Organic Synthesis Based on Name Reactions-2nd Ed., Tetrahedron Organic Chemistry Series, 22; Pergamon, Oxford, UK, 2002, p. 42.

[34] [a] F. M. Cordero, F. Pisaneschi, A. Goti, J. Ollivier, J. Salaün, A. Brandi, J. Am. Chem. Soc. 2000, 122, 8075-8076; [b] F. M. Cordero, F. Pisaneschi, M. Salvati, V. Paschetta, J. Ollivier, J. Salaün, A. Brandi, J. Org. Chem. 2003, 68, 3271-3278. 
[35] [a] M. Miura, M. Enna, K. Okuro, M. Nomura, J. Org. Chem. 1995, 60, 4999-5004; [b] M. Kinugasa, S. Hashimoto, J. Chem. Soc., Chem. Commun. 1972, 466-467; [c] R. Shintani, G. C. Fu, Angew. Chem. 2003, 115, 4216-4219; Angew. Chem. Int. Ed. 2003, 42, 4082-4085.

[36] [a] L. Stella, Angew. Chem. Int. Ed. 1983, 22, 337-350; [b] M. E. Wolff, Chem. Rev 1963, 63, 55-64.

[37] [a] A. Padwa, K. K. Koehler, A. Rodriguez, J. Org. Chem. 1984, 49, 282-288; [b] A. Padwa, K. K. Koehler, A. Rodriguez, J. Am. Chem. Soc. 1981, 103, 4974-4975.

[38] H. G. Aurich, J. -L. Ruiz Quintero, Tetrahedron 1994, 50, 3943-3950.

[39] L. W. A. van Berkom, G. J. T. Kuster, R. de Gelder, H. W. Scheeren, Eur. J. Org. Chem. 2004, 4397-4404.

[40] J. Salaun, M. S. Baird, Curr. Med. Chem. 1995, 2, 511-542.

[41] S. Cicchi, M. Corsi, A. Goti, J. Org. Chem. 1999, 64, 7243-7245.

[42] F. M. Cordero, F. Machetti, F. De Sarlo, A. Brandi, Gazz. Chim. Ital. 1997, 127, 25-29.

[43] H. Tokuyama, T. Kuboyama, A. Amano, T. Yamashita, T. Fukuyama, Synthesis 2000, 1299-1304.

[44] O. Tamura, T. Okabe, T. Yamaguchi, K. Gotanda, K. Noe, M. Sakamoto, Tetrahedron 1995, 51, 107-118.

[45] A. Hassan, M. Waseer, A. Sk. Asrof, J. Chem. Soc., Perkin Trans. II 1998, 393-400.

[46] R. Annunziata, M. Cinquini, F. Cozzi, P. Giaroni, L. Raimondi, Tetrahedron Let. 1991, $32,1659-1662$. 
[47] O. G. Kulinkovich, S. V. Sviridov, D. A. Vasilevski, Synthesis 1991, 234.

[48] A. de Meijere, S. I. Kozhushkov, T. Spaeth, N. S. Zefirov, J. Org. Chem. 1993, 58, $502-505$.

[49] A. Goti, F. M. Cordero, A. Brandi, Top. Curr. Chem. 1996, 178, 1-97.

[50] A. Goti, B. Anichini, A. Brandi, J. Org. Chem. 1996, 61, 1665-1672.

[51] F. M. Cordero, M. Salvati, F. Pisaneschi, A. Brandi, Eur. J. Org. Chem. 2004, $2205-2213$.

[52] [a] R. Sharma, R. J. Stoodley, A. Whiting, J. Chem. Soc., Perkin Trans. I 1987, 2361-2369; [b] P. H. Crackett, C. M. Pant, R. J. Stoodley, J. Chem. Soc., Perkin Trans. I 1984, 2785-2793; [c] J. Brennan, G. Richardson, R. J. Stoodley, J. Chem. Soc., Perkin Trans. I 1983, 649-655.

[53] C. M. Tice, B. Ganem, J. Org. Chem. 1983, 48, 5048-5050.

[54] [a] A. Vasella, Helv. Chim. Acta 1977, 60, 1273-1295; [b] E. J. Fornefeld, A. J. Pike, J. Org. Chem. 1979, 44, 835-839; [c] W. Oppolzer, Tetrahedron Lett. 1979, 4391-4394.

[55] I. S. Young, J. L. Williams, M. A. Kerr, Org. Lett. 2005, 7, 953-955.

[56] C. O. Kappe, Angew. Chem. 2004, 116, 6408-6443; Angew. Chem. Int. Ed. 2004, 43, $6250-6284$.

[57] R. Gedey, F. Smith, K. Westaway, H. Ali, L. Baldisera, L. Laberge, J. Roussel, Tetrahedron Lett. 1986, 27, 279-282.

[58] A. R. von Rippel, Dielectric Materials and Applications, MIT Press, Cambridge, MA, 1954. 
[59] C. Gabriel, S. Gabriel, E. H. Grant, B. S. J. Halstead, D. M. P. Mingos, Chem. Soc. Rev. 1998, 27, 213-223.

[60] [a] P. R. West, G. C. Davis, J. Org. Chem. 1989, 54, 5176-5180; [b] I. D. Entwistle, T. Gilkerson, R. A. W. Johnstone, R. P. Telford, Tetrahedron 1978, 34, $213-215$.

[61] [a] R. Signer, Helv. Chim. Acta 1930, 13, 43-46; [b] P. F. Schuda, C. B. Ebner, S. J. Potlock, Synthesis 1987, 12, 1055-1057.

[62] T. R. Kelly, T. E. Schmidt, J. G. Haggerty, Synthesis 1972, 544-545.

[63] F. M. Cordero, I. Barile, F. De Sarlo, A. Brandi, Tetrahedron Lett. 1999, 40, 6657-6660.

[64] [a] Y. Ogata, T. J. Morimoto, J. Org. Chem. 1965, 30, 597-600; [b] V. D. Simonou, T. V. Denisenko, V. I. Savchenko, S. Y. Sklyar, J. Org. Chem. USSR 1976, 12, 1048-1050.

[65] A. Zanobini, M. Gensini, J. Magull, D. Vidović, S. I. Kozhushkov, A. Brandi, A. de Meijere, Eur. J. Org. Chem. 2004, 4158-4166.

[66] A. Dömling, I. Ugi, Angew. Chem. 2000, 112, 3300-3344; Angew. Chem. Int. Ed. 2000, $39,3168-3210$.

[67] C. Zorn, B. Anichini, A. Goti, A. Brandi, S. I. Kozhushkov, A. de Meijere, L. Citti, J. Org. Chem. 1999, 64, 7846-7855.

[68] P. Lindström, J. Tierney, B. Wathey, J. Westmann, Tetrahedron 2001, 57, 9225-9283.

[69] [a] C. N. C. Drey, Chapter 3 in Chemistry and Biochemistry of Amino Acids, Peptides, and Proteins (Ed. G. C. Barnet), Chapman and Hall, London 1985, p. 25; [b] A. F. Spatola in Chemistry and Biochemistry of Amino Acids, Peptides and Proteins (Ed. B. Winstein), Marcel Dekker, New York, 1983, Vol. 7, p. 267. 
[70] [a] G. Cardillo, C. Tomasini, Chem. Soc. Rev. 1996, 25, 117-128; [b] T. Yasumoto, M. Satake, Chimia 1998, 52, 63-68; [c] C. A. Bewley, D. J. Faulkner, Angew. Chem. 1998, 110, 2280-2297; Angew. Chem. Int. Ed. 1998, 37, 2163-2178.

[71] K. D. Walker, H. G. Floss, J. Am. Chem. Soc 1998, 120, 5333-5334.

[72] [a] E. Abderhalden, F. Reich, Fermentforschung 1929, 11, 319-329; [b] E. Abderhalden, R. Fleischmann, Fermentforschung 1928, 10, 195-212.

[73] [a] R. P. Nargund, K. H. Barakat, K. Cheng, W. W.-S. Chen, B. R. Butler, R. G. Smith, A. A. Patchett, Bioorg. Med. Chem. Lett. 1996, 6, 1265-1270; [b] M. Llinares, C. Devin, J. Azay, G. Berge, J. A. Fehrentz, J. Martinez, Eur. J. Med. Chem. 1997, 32, 767-780; [c] K. Iijima, J. Katada, Y. Hayashi, Bioorg. Med. Chem. Lett. 1999, 9, 413-418.

[74] [a] T. Hintermann, D. Seebach, Chimia 1997, 50, 244-247; [b] D. Seebach, S. Abele, J. V. Schreiber, B. Martinoni, A. K. Nussbaum, H. Schild, H. Schulz, H. Henneke, R. Wössner, F. Bitsch, Chimia 1998, 52, 734-739.

[75] M. Bhupathy, J. J. Bergan, J. M. McNamara, R. P. Volanta, P. J. Reider, Tetrahedron Lett. 1995, 36, 9445-9448.

[76] C. Palomo, M. Oiarbide, S. Bindi, J. Org. Chem. 1998, 63, 2469-2474.

[77] I. Ojima, C. M. Sun, Y. H. Park, J. Org. Chem. 1994, 59, 1249-1250.

[78] M. Es-Sayed, Dissertation, Universität Hamburg, 1992.

[79] Ring opening of $\beta$-lactams with aryl substituents at C-4 under hydrogenolytic conditions has previously been observed: [a] I. Ojima, S. Suga, R. Abe, Tetrahedron Lett. 1980, 21, 3907-3910. [b] I. Ojima, N. Hatanaka, N. Yodo, R. Abe, M. Yatabe, M. Yamashita in Peptide Chemistry 1982 (Ed.: S. Sakakibara), Protein Research Foundation, Osaka, 1983, pp. 29-34; [c] I. Ojima, in Advances in Asymmetric Synthesis (Ed. Hassner), Jai Press Inc. Greenwich, CT, 1995, Vol. 1, pp. 95. 
[80] [a] J. Aszodi, A. Bonnet, G. Teutsch, Tetrahedron 1990, 46, 1579-1586; [b] G. D. Annis, E. M. Hebblethwaite, S. T. Hodgson, D. M. Hollinshead, S. V. Ley, J. Chem. Soc. Perkin Trans. 1 1983, 2851-2856; [c] R. M. Williams, E. Kwast, Tetrahedron Lett. 1989, 30, 451454.

[81] [a] V. Moreaux, H. Warren, J. M. Williams, Tetrahedron Lett. 1997, 38, 4655-4658. [b] J. M. Blanco, O. Caamanno, F. Fernandez, X. Garsia Mera, C. Lopez, G. Rodriguez, J. E. Rodriguez-Borges, A. Rodriguez-Hergueta, Tetrahedron Lett. 1998, 39, 5663-5666. [c] B. Alcaide, A. Gomez, J. Plumet, J. Rodrigez-Lopez, Tetrahedron 1989, 45, 2751-2762.

[82] M. I. Page, Adv. Phys. Org. Chem 1987, 23, 165-270.

[83] I. Ojima, Acc. Chem. Res. 1995, 28, 383-389.

[84] [a] X. Daura, W. F. van Gusteren, D. Rigo, B. Jaun, D. Seebach, Chem. Eur. J. 1997, 3, 1410-1417; [b] X. Daura, B. Jaun, D. Seebach, W. F. van Gunsteren, A. E. Mark, J. Mol. Biol. 1998, 280, 925-932; [c] X. Daura, K. Gademann, B. Jaun, D. Seebach, W. F. van Gunsteren, A. E. Mark, Angew. Chem. 1999, 111, 249-253; Angew. Chem. Int. Ed. 1999, 38, $236-240$.

[85] [a] R. Graf, G. Lohaus, K. Börner, E. Schmidt, H. Bestian, Angew. Chem. 1962, 74, 523; Angew. Chem. Int. Ed. 1962, 1, 481-488; [b] H. Bestian, Angew. Chem. 1968, 80, 304-312; Angew. Chem. Int. Ed. 1968, 7, 278-285 [c] E. Schmidt, Angew. Makromol. Chem. 1970, 14, $185-202$.

[86] [a] A. Rodíguez-Galán, S. Muñoz-Guerra, J. A. Subirana, B. Chuong, H. Sekiguchi, Makromol. Chem., Makromol. Symp. 1986, 6, 277-284; [b] S. Muñoz-Guerra, F. LópezCarrasquero, J. M. Fernández-Santin, J. A. Subirana in Encyclopedia of Polymeric Materials (Ed.: J. C. Salamone), CRC Press: Boca Raton, FL, 1996, pp 4694-4700; [c] A. M. Ilarduya, C. Alaman, M. Garcia-Alvarez, F. López-Carrasquero, S. Muñoz-Guerra, Macromolecules 1999, 32, 3257-3263. 
[87] [a] F. Chen, G. Lepore, M. Goodmann, Macromolecules 1974, 7, 779-783; [b] H. W. Siesler, Polymer 1974, 15, 146-148; [c] S. R. Turner, R. C. Schulz, Makromol. Chem. 1975, 176, 501-506; [d] H. R. Krichelsdorf, G. Schilling, Makromol. Chem. 1978, 179, 2667-2674; [e] H. Yuki, Y. Okamoto, Y. Taketani, T. Tsubota, Y. Marubayashi, J. Polym. Chem. Ed. 1978, 16, 2237-2251; [f] J. Masamoto, K. Sasaguri, C. Ohizumi, H. Kobayashi, J. Polym. Sci., Part A-2 1978, 8, 1703; [g] E. J. Günster, R. C. Schulz, Makromol. Chem. 1980, 181, $643-649$.

[88] J. Kovacs, R. Ballina, R. Rodin, D. Balasubramanian, J. Applequist, J. Am. Chem. Soc. 1965, 87, 119-120.

[89] P. M. Hardy, J. Haylock, H. Rydon, J. Chem. Soc., Perkin Trans. 1 1972, 605-611.

[90] H. Yuki, Y. Okamoto, Y. Taketani, T. Tsubota, Y. Marubayashi, J. Polym. Sci., Polym. Chem. Ed. 1978, 16, 2237-2251.

[91] [a] J. M. Fernández-Santin, J. Aymami, A. Rodíguez-Galán, S. Muñoz-Guerra, J. A. Subirana, Nature 1984, 311, 53-54; [b] J. M. Fernández-Santin, S. Muñoz-Guerra, A. Rodíguez-Galán, J. Aymami, J. Lloveras, J. A. Subirana, E. Giralt, M. Ptak, Macromolecules 1987, 20, 62-68.

[92] [a] J. Cheng, J. W. Ziller, T. J. Deming, Org. Lett. 1999, 2, 1943-1946; [b] J. Cheng, T. J. Deming, Macromolecules 2001, 34, 5169-5174.

[93] [a] L. Birkofer, R. Modic, Liebigs Ann. Chem. 1957, 604, 56; [b] L. Birkofer, R. Modic, Liebigs Ann. Chem. 1959, 628, 162-172.

[94] A. Zilkha, Y. Burstein, Biopolymers 1964, 2, 147-161.

[95] H. Kricheldorf, $\alpha$-Aminoacid-N-carboxyanhydrides and Related Heterocycles; SpringerVerlag: Berlin, New York, 1987.

[96] L. Jia, E. Ding, W. R. Anderson, Chem. Commun. 2001, 1436-1437. 
[97] [a] C. D. Eisenach, R. W. Lenz, Macromolecules 1976, 9, 227-230; [b] C. D. Eisenach, R. W. Lenz, Makromol. Chem. 1979, 180, 429-440.

[98] [a] K. Hashimoto, M. Okata, S. Nagata, J. Polym. Sci., Part A: Polym. Chem. 1995, 33, 1995-1999; [b] K. Hashimoto, T. Oi, J. Yasuda, K. Hotta, M. Okata, J. Polym. Sci., Part A: Polym. Chem. 1997, 35, 1831-1838; [c] K. Hashimoto, J. Yasuda, M. Kobayashi, J. Polym. Sci., Part A: Polym. Chem. 1999, 37, 909-915.

[99] J. Šebenda, J. Hauer, Polym. Bull. 1981, 5, 529-534.

[100] J. Cheng, T. J. Deming, J. Am. Chem. Soc. 2001, 123, 9457-9458.

[101] D. A. White, Synth. Commun. 1977, 7, 559.

[102] [a] L. W. Jones, A. W. Scott, J. Am. Chem. Soc. 1922, 44, 407-423; [b] A. D. Mitchell, J. F. Thorpe, J. Chem. Soc. 1910, 97, 997-1004.

[103] D. Seebach, S. Abele, T. Sifferlen, M. Hänggi, S. Gruner, P. Seiler, Helv. Chim. Acta 1998, 81, 2218-2243.

[104] N. Kise, N. Ueda, J. Org. Chem. 1999, 64, 7511-7514.

[105] T. Shono, K. Tsubata, N. Okinaga, J. Org. Chem. 1984, 49, 1056-1059.

[106] A. Avenoza, C. Cativiela, M. París, J. M. Peregrina, Tet. Asymmetry 1995, 6, 1409-1418.

[107] M. A. Bonache, G. Gerona Navarro, C. García Apparicio, M. Alías, M. Martín Martínez, M. T. García Lopez, D. Lopez, C. Cativiela, R. Gonzalez-Muñiz, Tet. Asymmetry 2003, 14, 2161-2169.

[108] T. Mukaiyama, Angew. Chem. 1976, 4, 111-120. 
[109] M. Fournier, R. E. Prud'homme, J. Polym. Sci., Part A: Polym. Chem. 1999, 37, 761-769.

[110] A. Vollmar, M. S. Dunn, J. Org. Chem. 1960, 25, 387-390.

[111] N. N. Schwarz, J. N. Blumberg, J. Org. Chem. 1964, 29, 1976-1979. 
F. Spectral Data 
Methyl 8-Benzyl-8-aza-7-oxadispiro[2.0.2.3]nonane-9-carboxylate (47b)

${ }^{1} \mathrm{H}-\mathrm{NMR}\left(250 \mathrm{MHz}, \mathrm{CDCl}_{3}\right)$
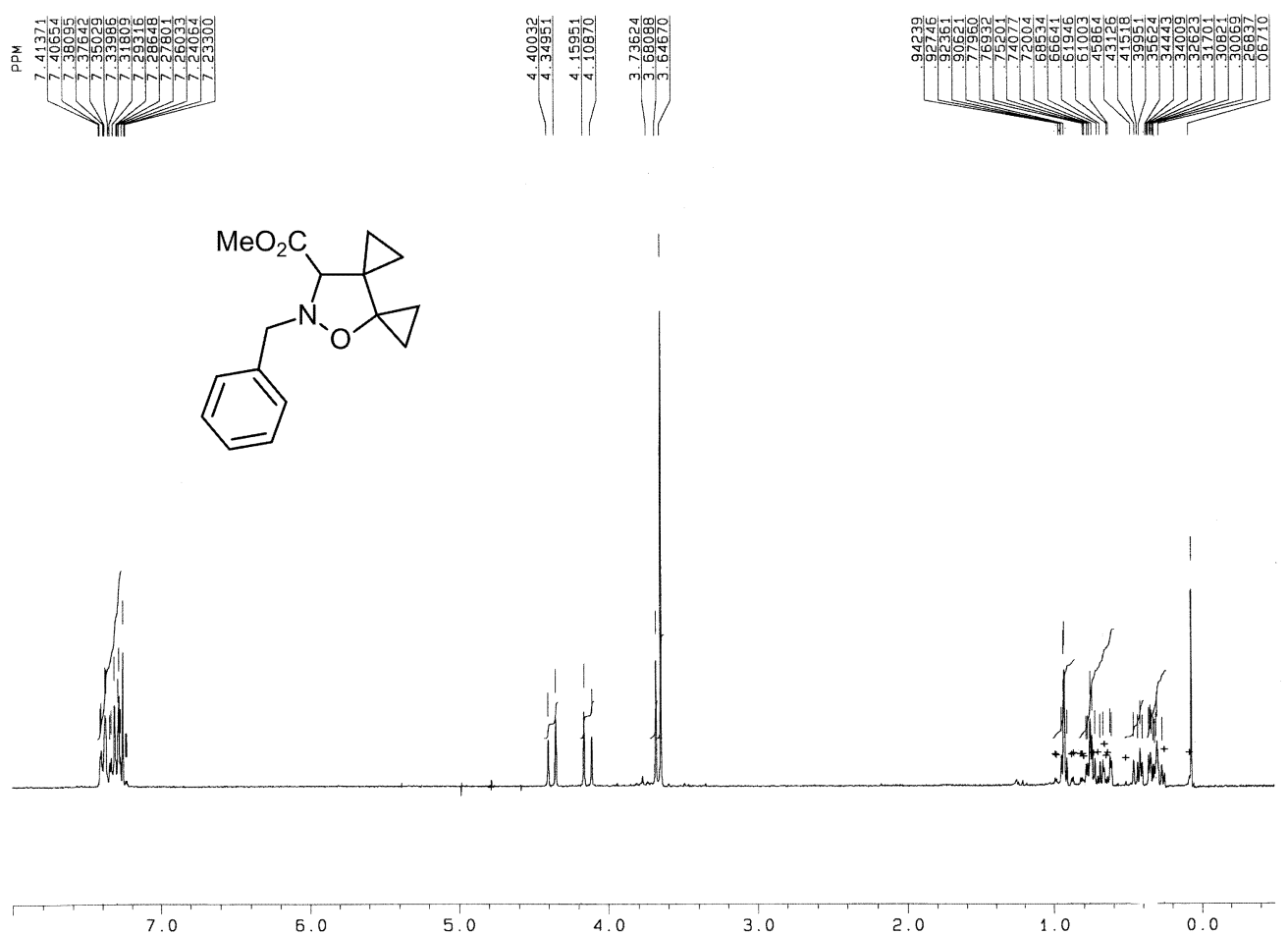

5.0

${ }^{4 .}{ }_{\mathrm{PPM}}$

3.0

2.0

1.0

8-Benzyl-9-cyano-8-aza-7-oxadispiro[2.0.2.3]nonane (47d) ${ }^{1} \mathrm{H}-\mathrm{NMR}\left(250 \mathrm{MHz}, \mathrm{CDCl}_{3}\right)$

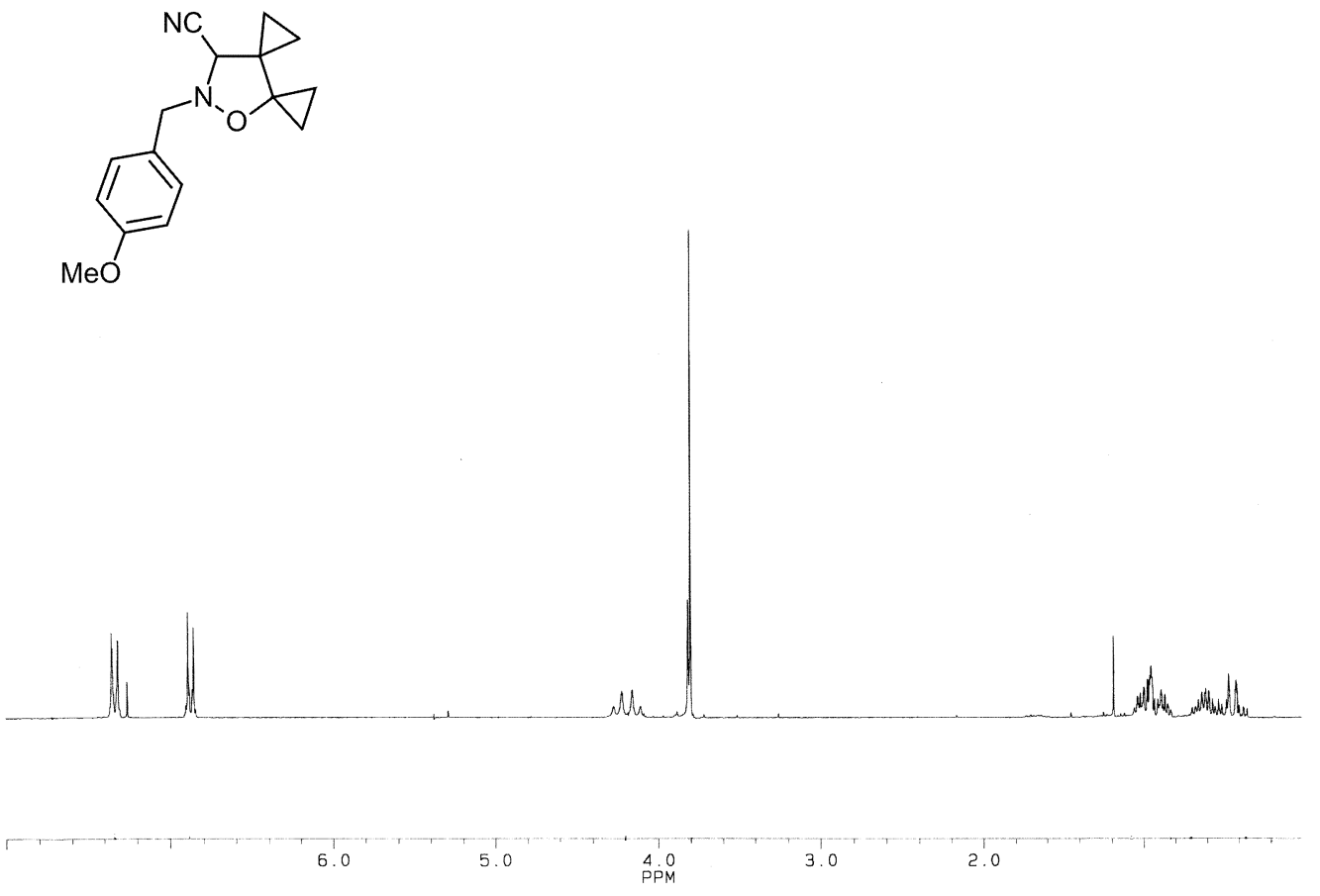


Ethyl 8-tert-butyl-7-oxa-8-azadispiro[2.0.2.3]nonane-9-carboxylate (47f-Et) ${ }^{1} \mathrm{H}-\mathrm{NMR}\left(250 \mathrm{MHz}, \mathrm{CDCl}_{3}\right)$
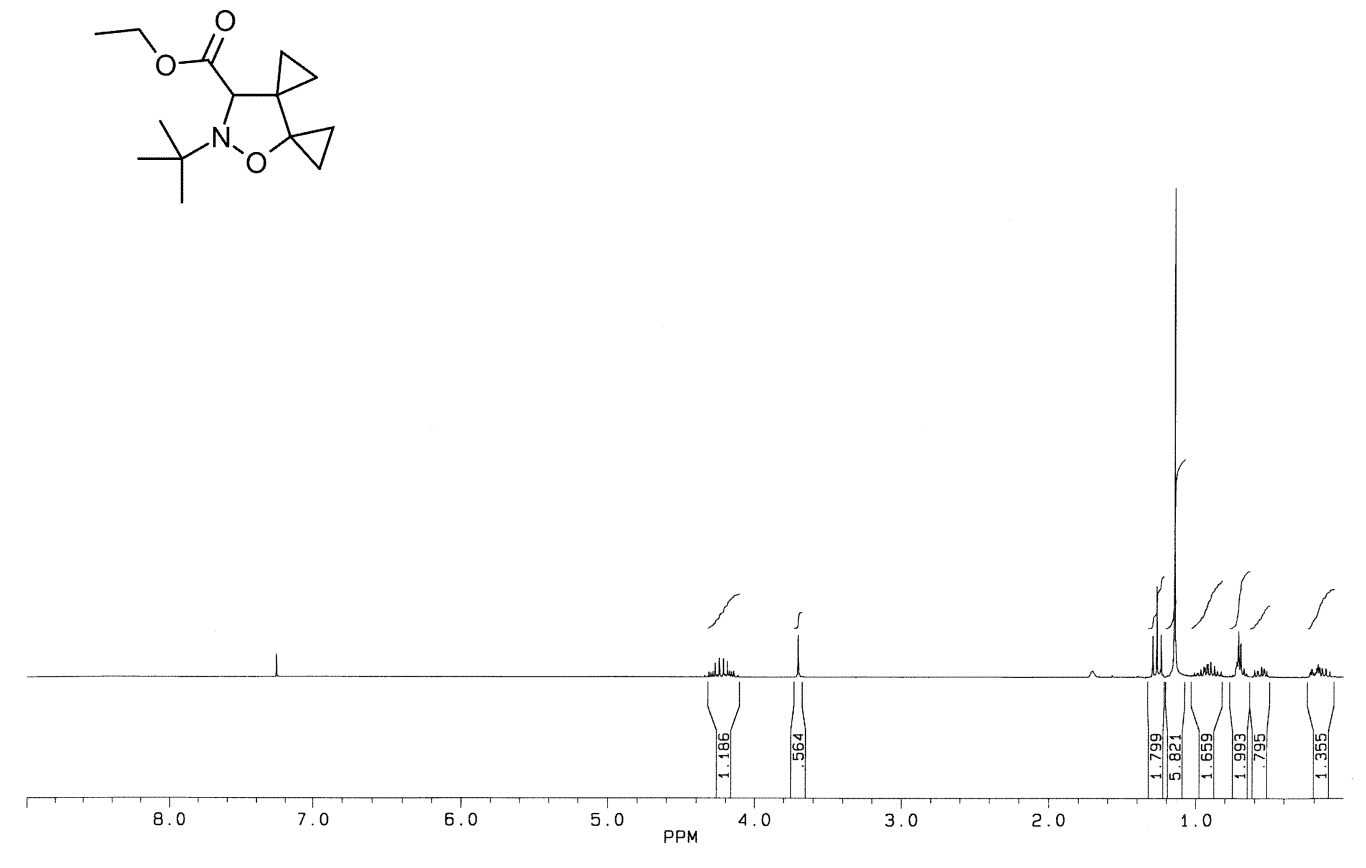

Methyl 5-Benzyl-6-oxo-5-azaspiro[2.3] hexane-4-carboxylate (53b) ${ }^{1} \mathrm{H}-\mathrm{NMR}\left(250 \mathrm{MHz}, \mathrm{CDCl}_{3}\right)$

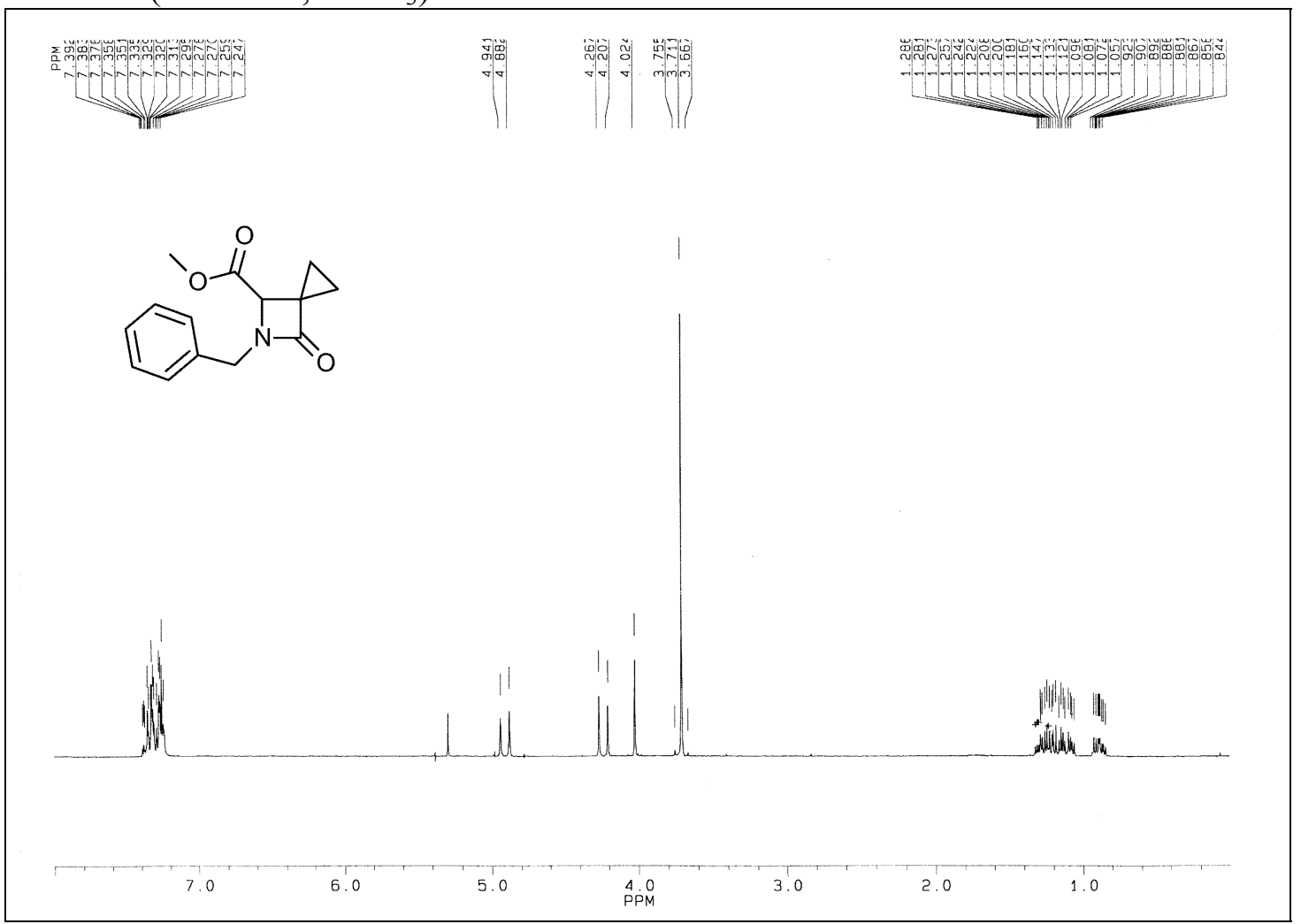


5-(p-Methoxybenzyl)-5-azaspiro[2.3]hexan-4-one (53g) ${ }^{1} \mathrm{H}-\mathrm{NMR}\left(250 \mathrm{MHz}, \mathrm{CDCl}_{3}\right)$

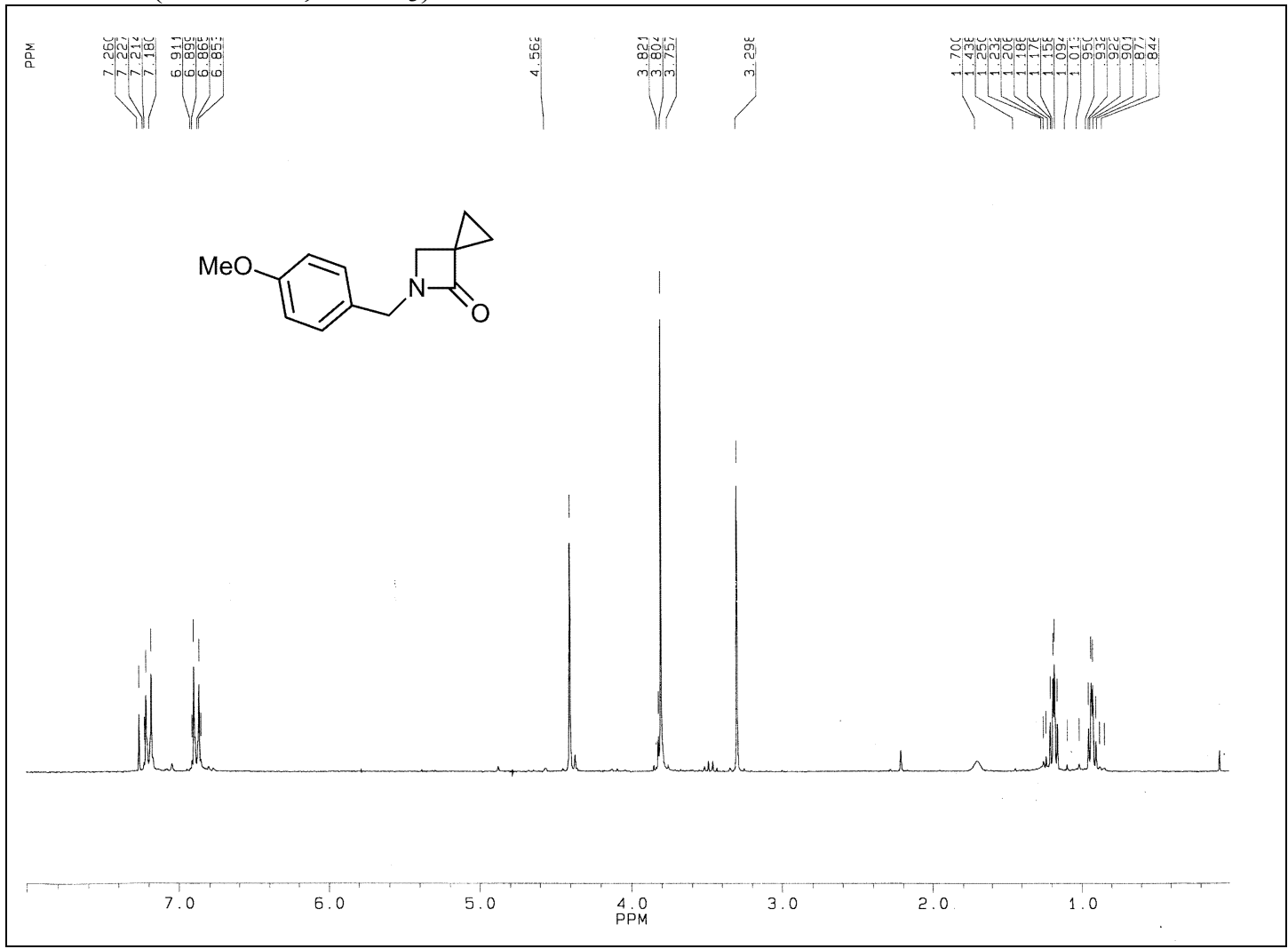

Ethyl 5-benzyl-6-oxo-5-azaspiro[2.3]hexane-4-carboxylate (77c-Et) ${ }^{1} \mathrm{H}-\mathrm{NMR}\left(300 \mathrm{MHz}, \mathrm{CDCl}_{3}\right)$

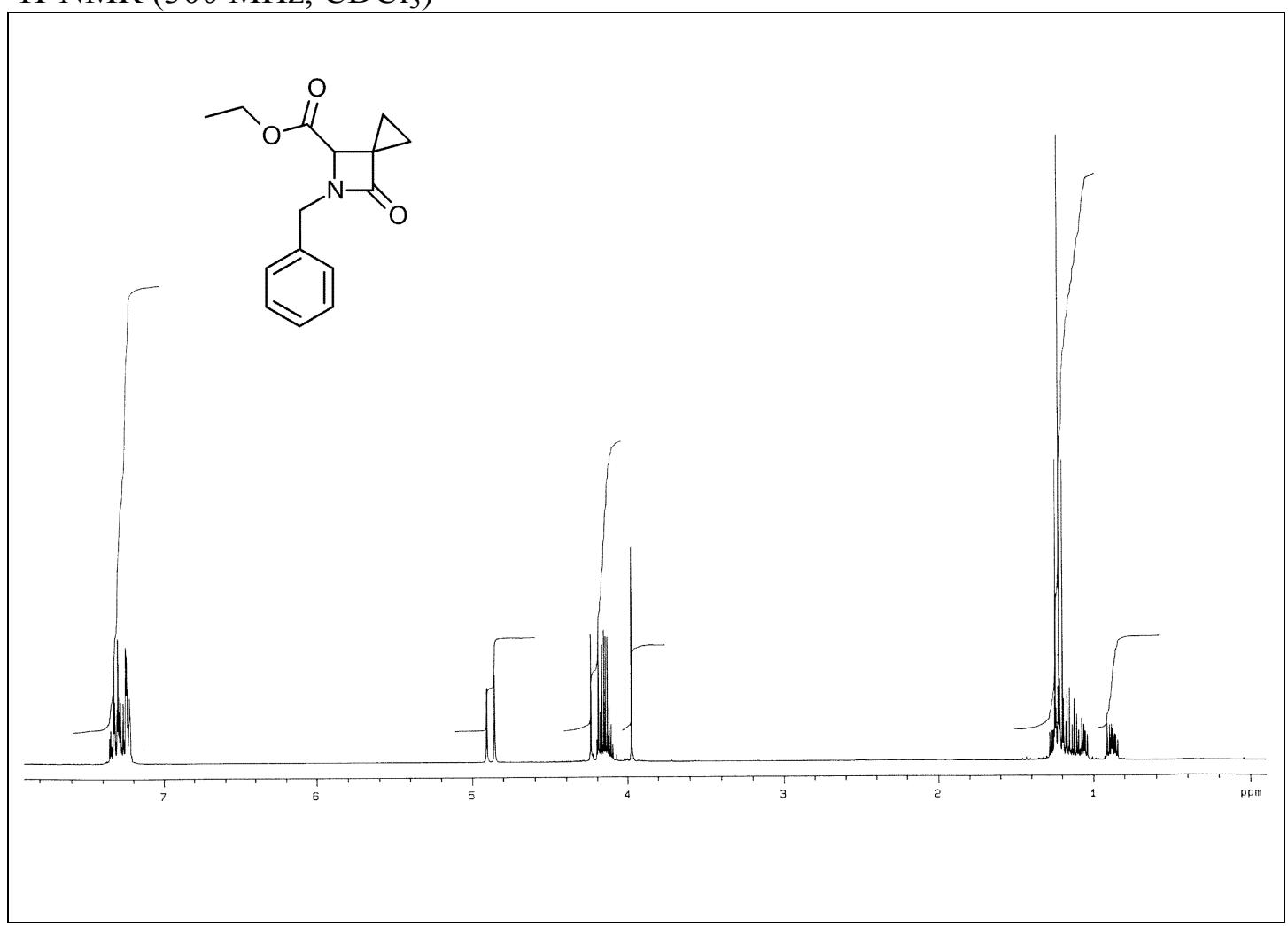


tert-Butyl \{[1-(Benzoylaminophenylmethyl)cyclopropylcarbonyl]amino\}acetate (116)

${ }^{1} \mathrm{H}-\mathrm{NMR}\left(300 \mathrm{MHz}, \mathrm{CDCl}_{3}\right)$<smiles>CCCCC(=O)NCC(=O)C1(C(NC(=O)c2ccccc2)c2ccccc2)CC1</smiles>

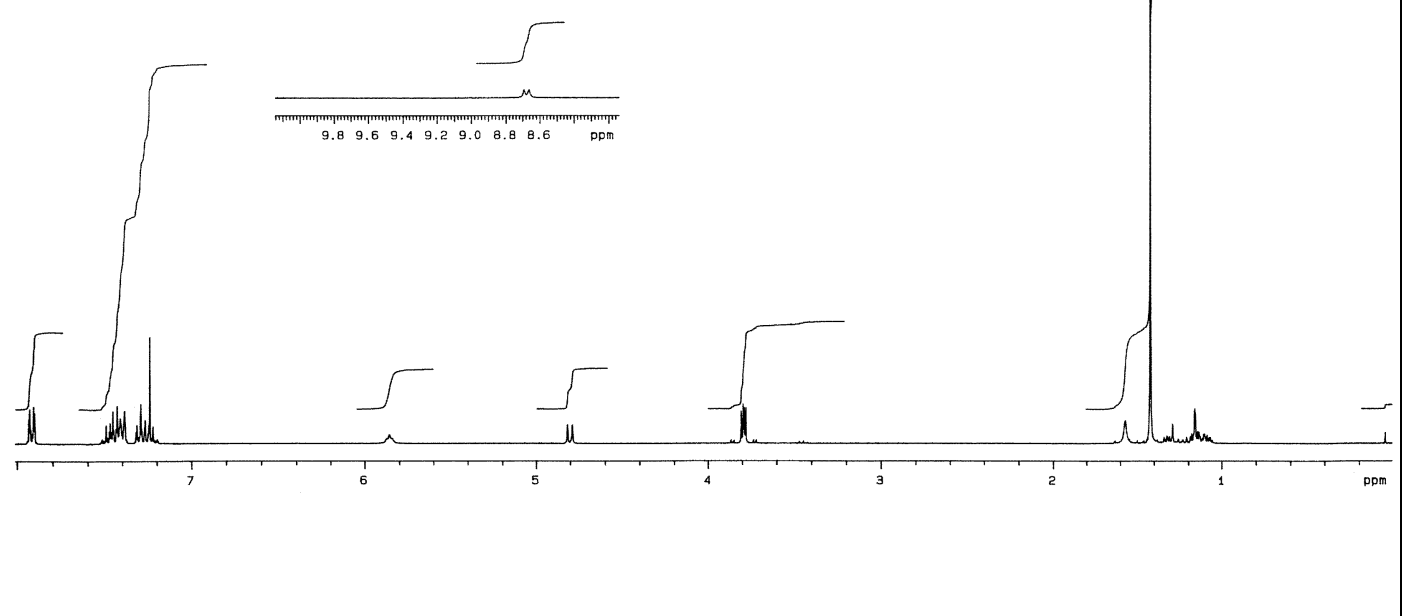

tert-Butyl $\{[1-($ tert-Butoxycarbonylaminocyanomethyl)cyclopropylcarbonyl $]$ amino $\}$ acetate (117)

${ }^{1} \mathrm{H}-\mathrm{NMR}\left(300 \mathrm{MHz}, \mathrm{CDCl}_{3}\right)$<smiles>CCCCOC(=O)CNC(=O)C1(C(C#N)NC(=O)OC(C)(C)C)CC1</smiles>

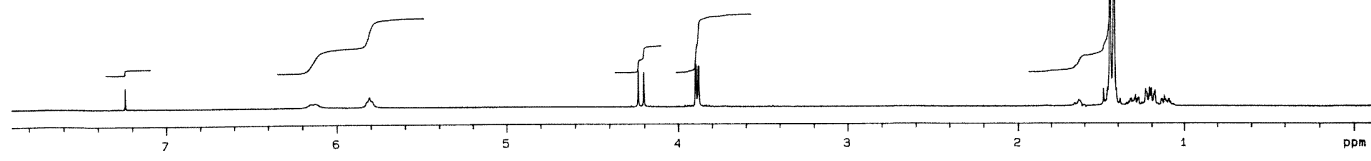


8-(p-Methoxybenzyl)-9-(2-iodophenyl)-7-oxa-8-azadispiro[2.0.2.3]nonane (47f) $\mathrm{APT}\left(50.3 \mathrm{MHz}, \mathrm{CDCl}_{3}\right)$

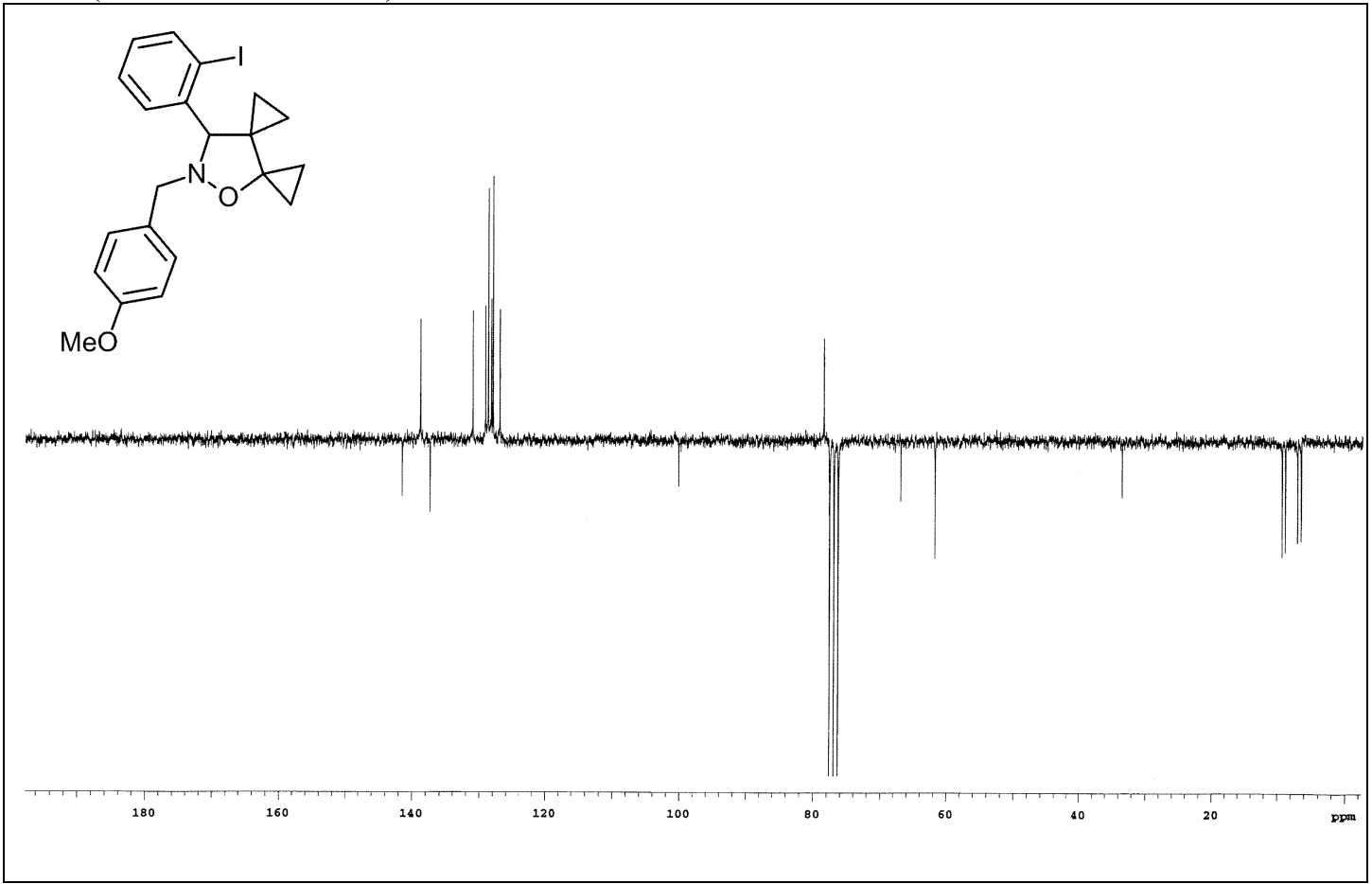

Ethyl 5-tert-butyl-6-oxo-5-azaspiro[2.3]hexane-4-carboxylate (77f-Et) APT $\left(75.5 \mathrm{MHz}, \mathrm{CDCl}_{3}\right)$

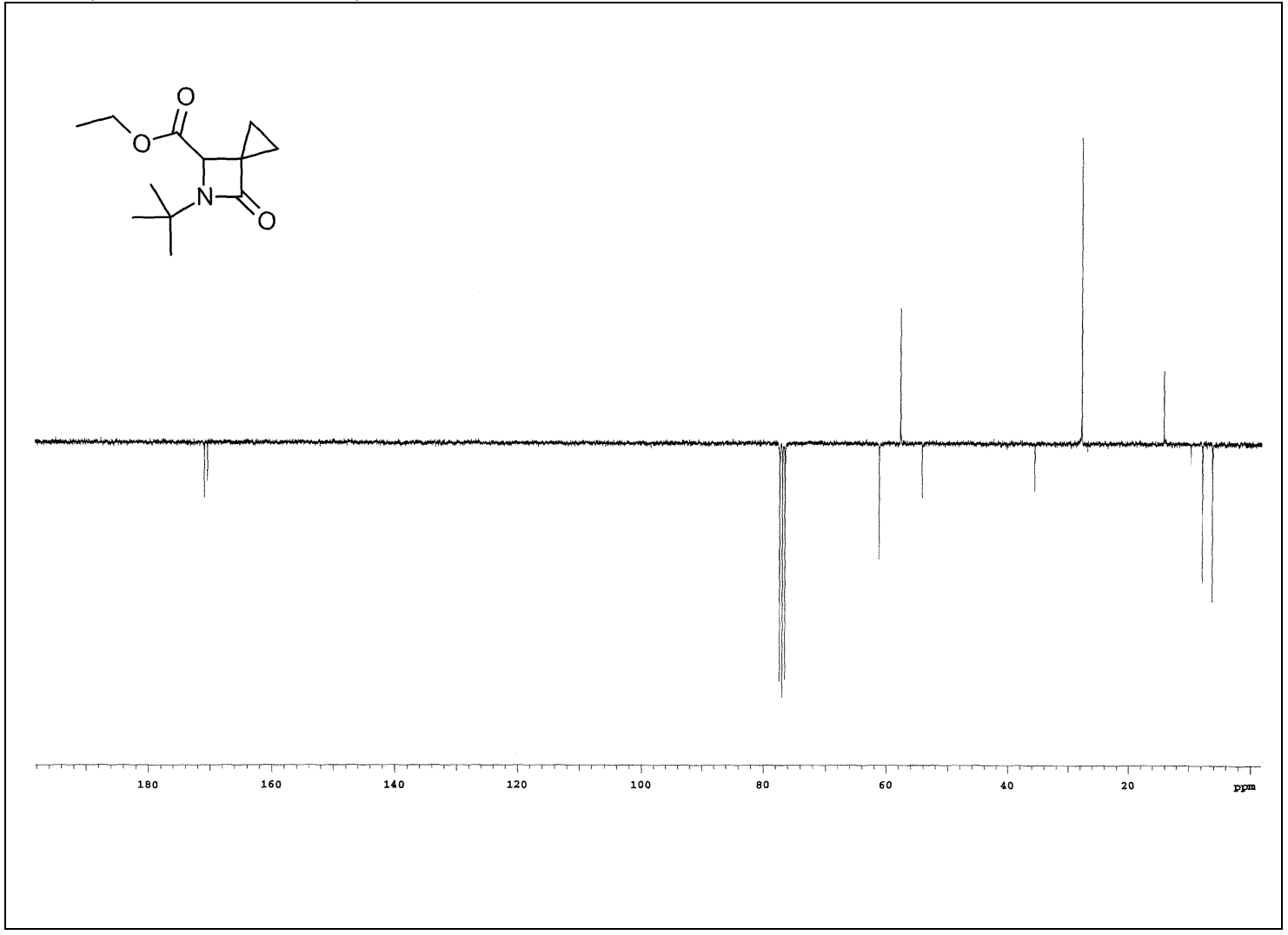


Cyclohexyl 5-benzyl-6-oxo-5-azaspiro[2.3] hexane-4-carboxylate (77c-cHex) $\operatorname{APT}\left(50.3 \mathrm{MHz}, \mathrm{CDCl}_{3}\right)$

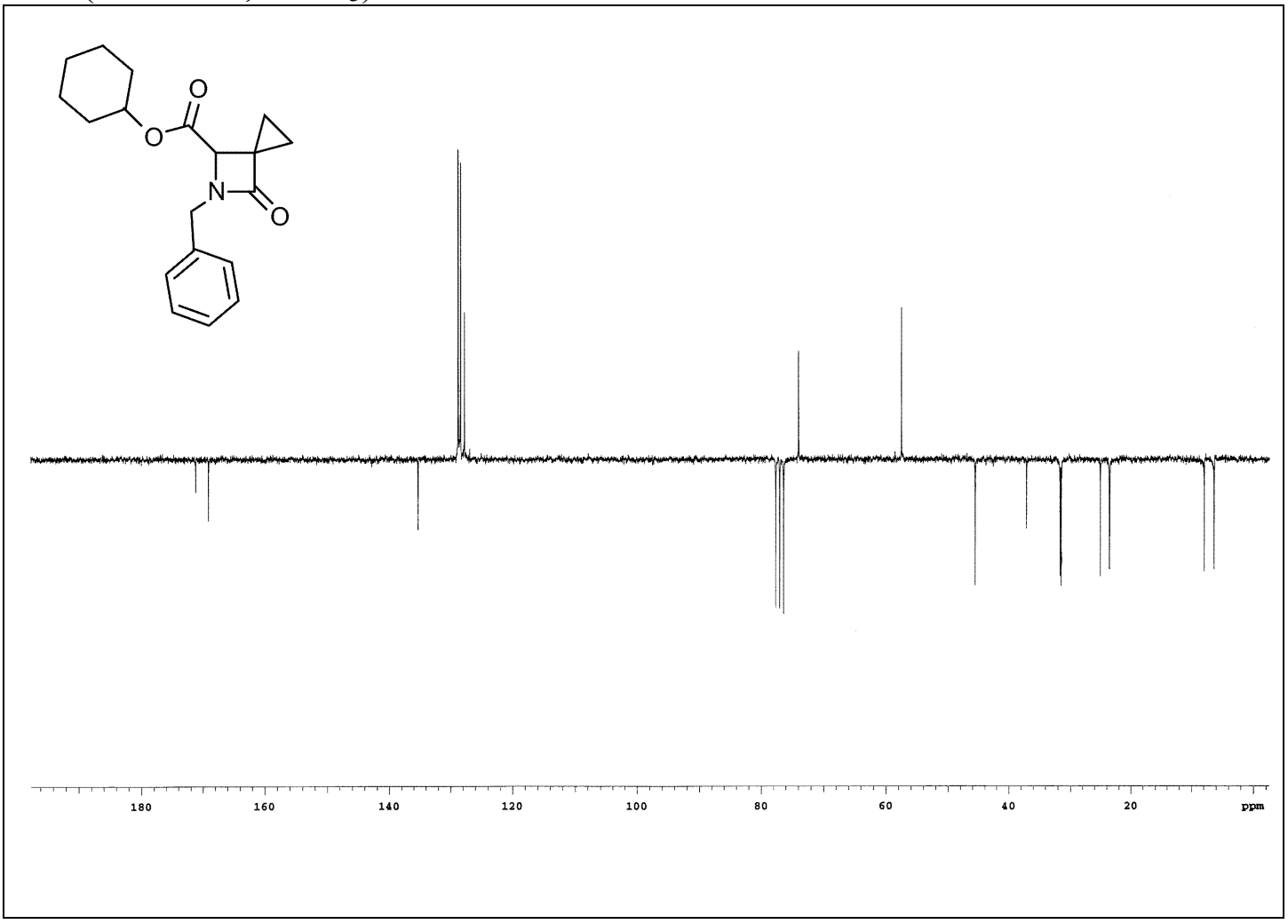

tert-Butyl [(5-Benzoyl-6-oxo-5-azaspiro[2.3] hexane-4-carbonyl)amino]acetate (114) APT $\left(150 \mathrm{MHz}, \mathrm{CDCl}_{3}\right)$

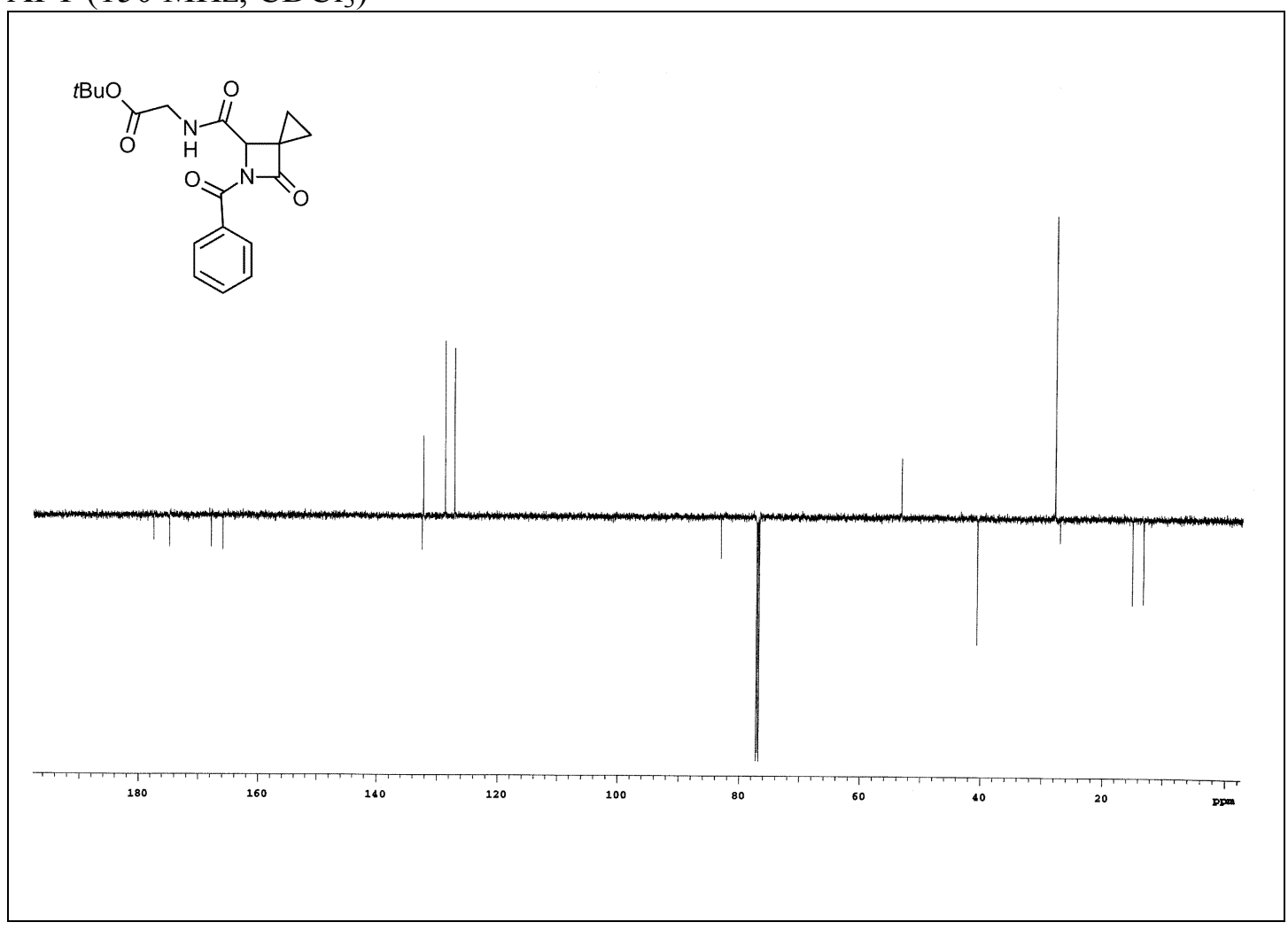


tert-Butyl $\{[1-($ tert-Butoxycarbonylaminocyanomethyl)cyclopropylcarbonyl]amino\}acetate (117)

${ }^{13} \mathrm{C}-\mathrm{NMR}\left(50.3 \mathrm{MHz}, \mathrm{CDCl}_{3}\right)$

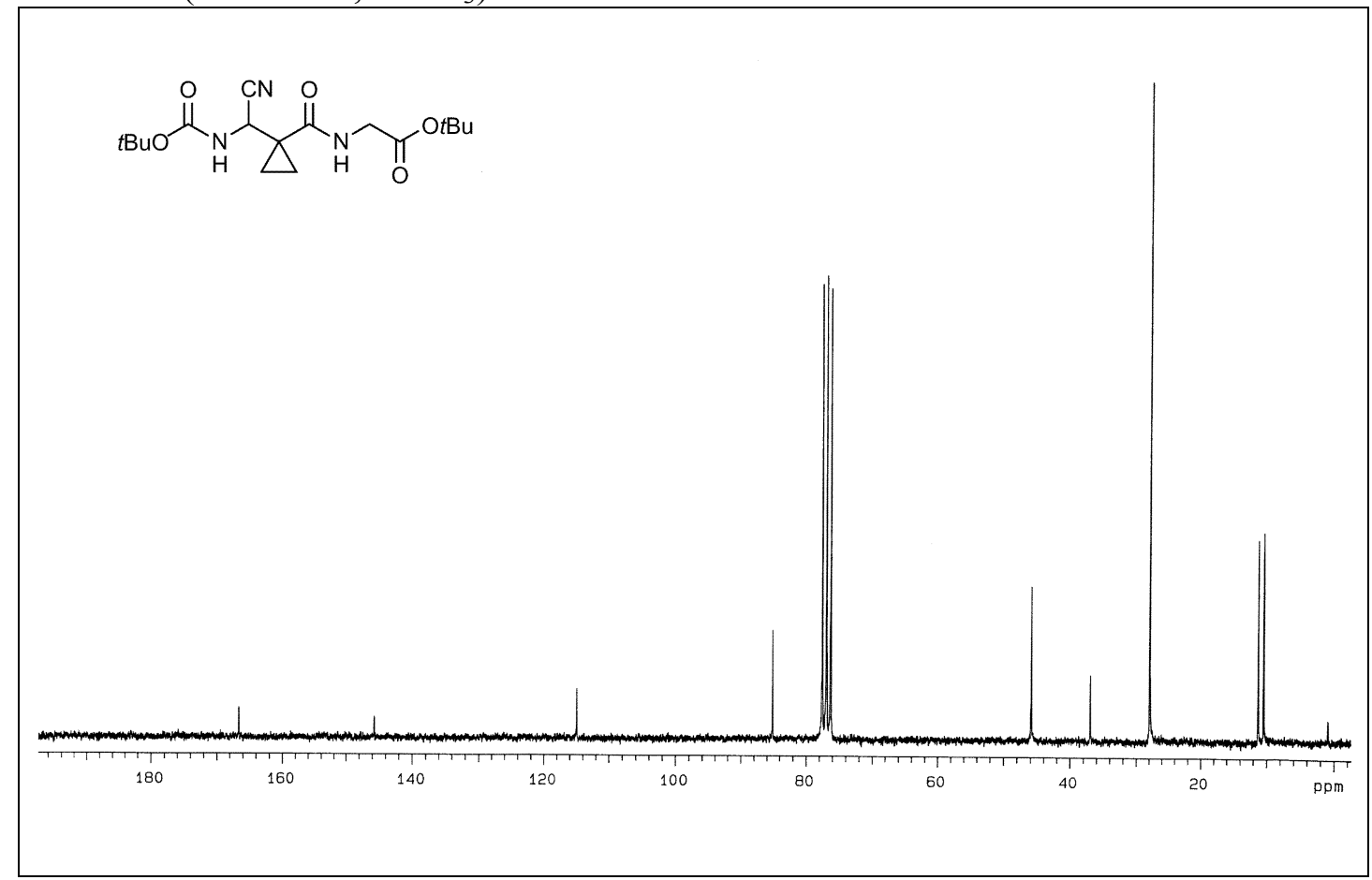

1-[1-(2,2,2-Trifluoroacetyl)-pyrrolidin-2-yl]-cyclopropane carboxylic acid (72) ${ }^{13} \mathrm{C}-\mathrm{NMR}\left(75.5 \mathrm{MHz}, \mathrm{CDCl}_{3}\right)$

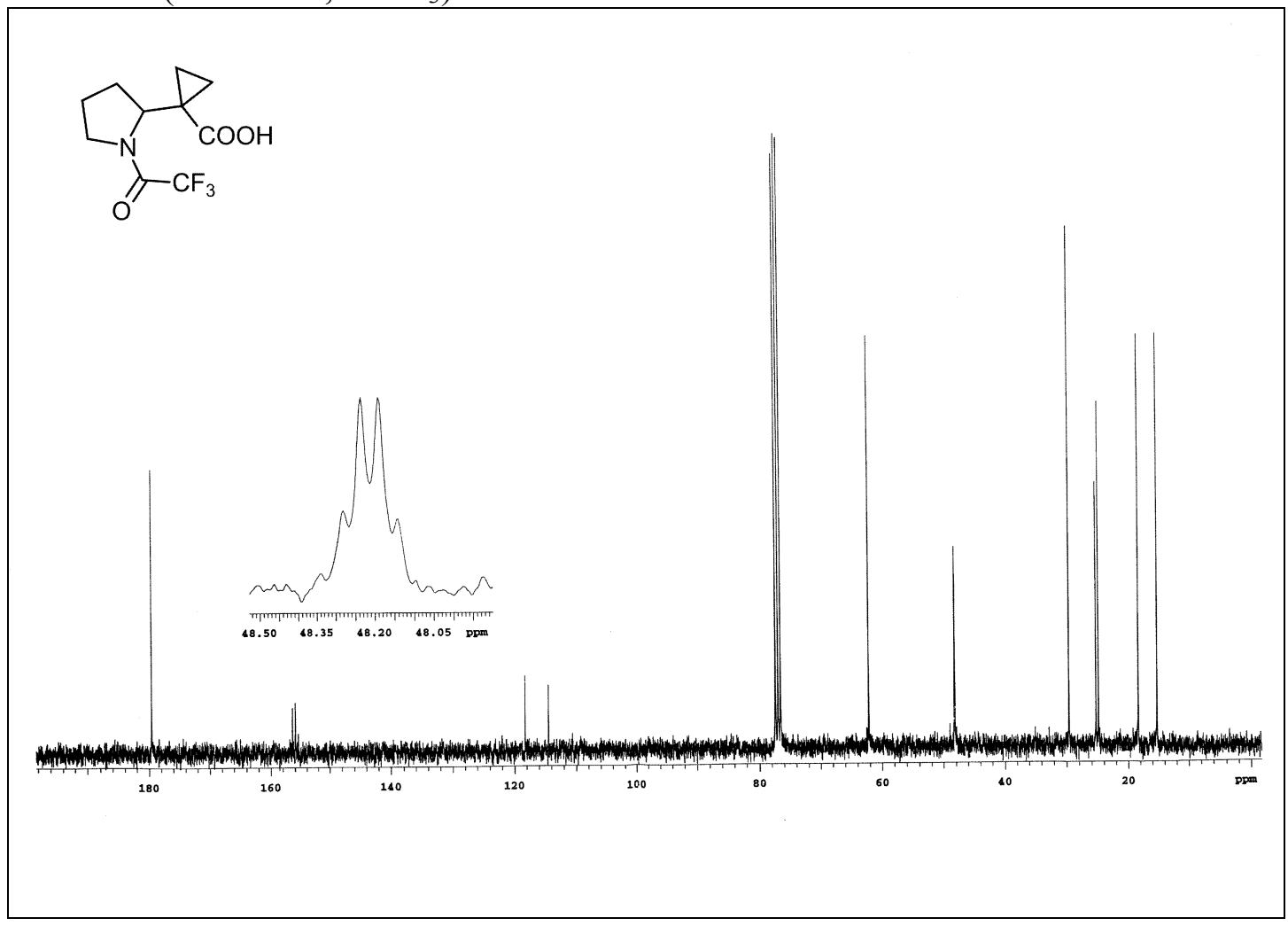


Poly(3-Phenyl-2-azetidinone) (154)

ESI mass spectra

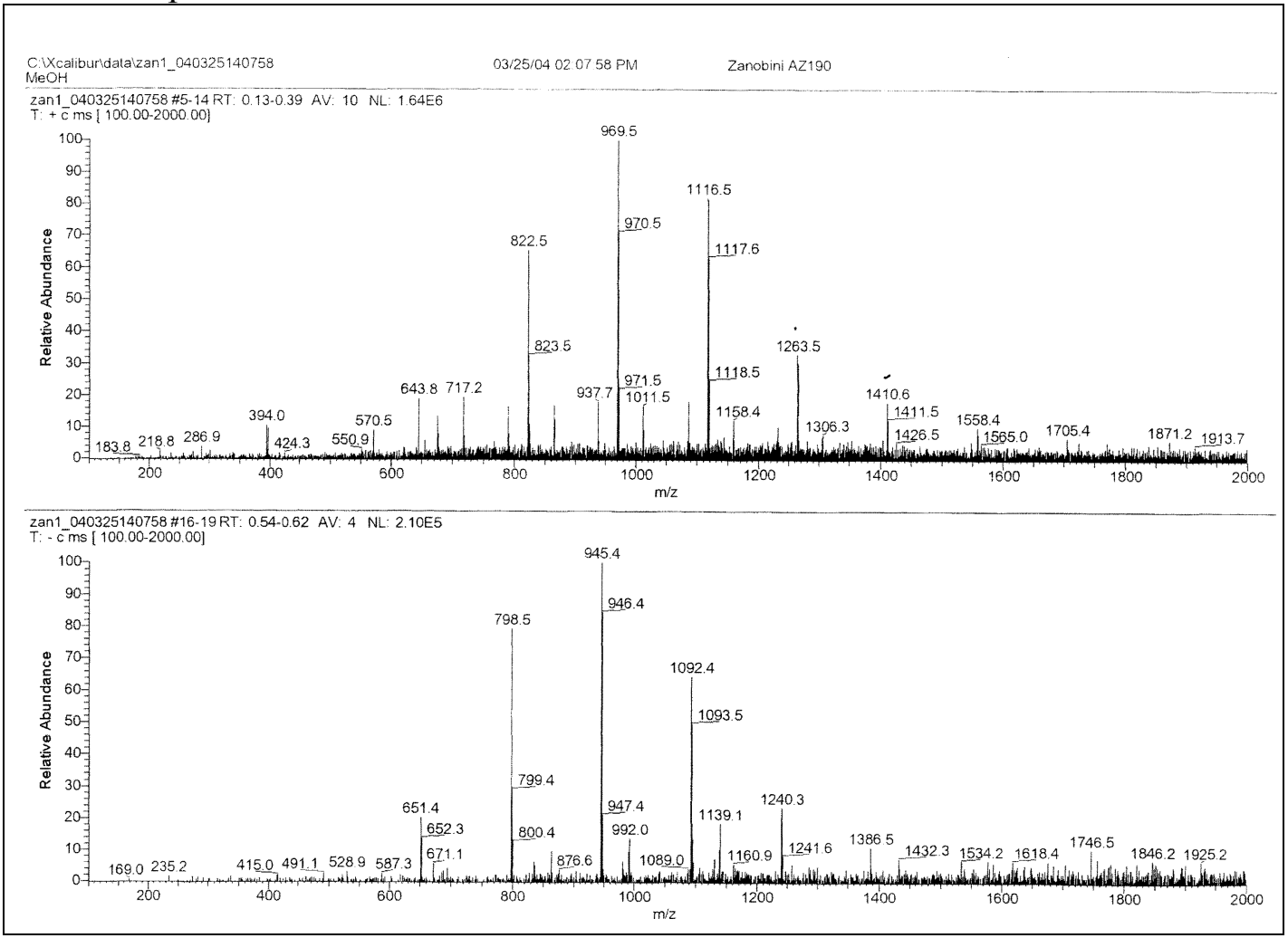




\section{G. Crystal Structural Data}

1. 8-Benzyl-9-phenyl-8-aza-7-oxadispiro[2.0.2.3]nonane (47a)

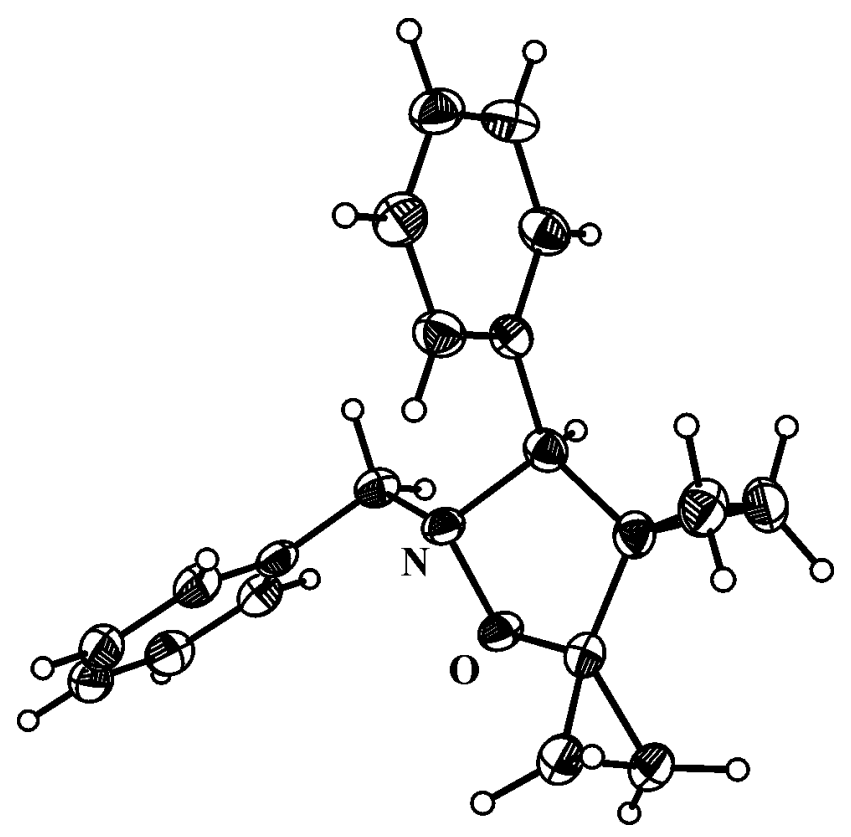

Table 1.1. Crystal data and structure refinement.

\begin{tabular}{ll}
\hline Empirical Formula & $\mathrm{C}_{20} \mathrm{H}_{21} \mathrm{NO}$ \\
Formula weight, g/mol & 291.38 \\
Crystal systesm & monoclinic \\
Space group & $\mathrm{P} 21 / \mathrm{n}$ \\
Unit cell dimensions & \\
$\mathrm{a}, \AA$ & $9.2097(7)$ \\
$\mathrm{b}, \AA$ & $5.6716(3)$ \\
$\mathrm{c}, \AA$ & $30.290(2)$ \\
$\alpha,{ }^{\circ}$ & 90 \\
$\beta,{ }^{\circ}$ & $94.307(6)$ \\
$\gamma,{ }^{\circ}$ & 90 \\
Volume, $\AA^{3}$ & $1577.70(19)$ \\
$\mathrm{Z}$ & 4 \\
Calculated density, $\mathrm{Mg} / \mathrm{m}^{3}$ & 1.227 \\
Absorption coefficient, $\mathrm{mm}^{-1}$ & 0.075 \\
F(000) & 624
\end{tabular}


$\Theta$-Range, ${ }^{\circ}$

Observed Reflections

Reflections collected/ unique [Rint]

Data/Restraints/Parameter

Goof $\mathrm{F}^{2}$

$\mathrm{R}_{1}, \mathrm{wR}_{2}$ values [I $\left.>2 \sigma(\mathrm{I})\right]$

$\mathrm{R}_{1}, \mathrm{wR}_{2}$ values (all data)

Largest diff. peak and hole, e $\cdot \AA^{-3}$
1.35 to 23.25

1979

$7117 / 2237$ [0.0327]

2237 / 0 / 199

1.040

$0.0310,0.0738$

$0.0367,0.0768$

0.183 and -0.136

Tabelle 1.2. Atomic coordinates and equivalent isotropic displacement parameters $(\AA 2)$. $\mathrm{U}(\mathrm{eq})$ is defined as one third of the trace of the orthogonalized Uij tensor.

\begin{tabular}{|c|c|c|c|c|}
\hline Atom & $\mathrm{x}$ & $\mathrm{y}$ & $\mathrm{z}$ & $\mathrm{U}(\mathrm{eq})$ \\
\hline $\mathrm{O}(7)$ & $0.1661(1)$ & $0.3274(2)$ & $0.1504(1)$ & $0.0244(2)$ \\
\hline $\mathrm{N}(8)$ & $0.0253(1)$ & $0.3141(2)$ & $0.1235(1)$ & $0.0225(3)$ \\
\hline $\mathrm{C}(1)$ & $-0.0500(2)$ & $0.2030(3)$ & $0.2415(1)$ & $0.0362(4)$ \\
\hline$C(2)$ & $-0.0888(2)$ & $-0.0184(3)$ & $0.2158(1)$ & $0.0342(4)$ \\
\hline$C(3)$ & $-0.0080(1)$ & $0.1762(2)$ & $0.1949(1)$ & $0.0254(3)$ \\
\hline$C(4)$ & $0.2259(1)$ & $-0.0768(2)$ & $0.1775(1)$ & $0.0283(3)$ \\
\hline$C(5)$ & $0.2785(1)$ & $0.1007(2)$ & $0.2127(1)$ & $0.0286(3)$ \\
\hline$C(6)$ & $0.1475(1)$ & $0.1511(2)$ & $0.1826(1)$ & $0.0229(3)$ \\
\hline$C(9)$ & $-0.0777(1)$ & $0.3380(2)$ & $0.1586(1)$ & $0.0245(2)$ \\
\hline$C(10)$ & $-0.2311(1)$ & $0.2868(2)$ & $0.1404(1)$ & $0.0239(2)$ \\
\hline $\mathrm{C}(11)$ & $-0.3422(1)$ & $0.4436(2)$ & $0.1478(1)$ & $0.0300(2)$ \\
\hline $\mathrm{C}(12)$ & $-0.4834(2)$ & $0.4046(3)$ & $0.1300(1)$ & $0.0335(3)$ \\
\hline$C(13)$ & $-0.5145(2)$ & $0.2084(3)$ & $0.1041(1)$ & $0.0322(3)$ \\
\hline$C(14)$ & $-0.4052(1)$ & $0.0493(3)$ & $0.0969(1)$ & $0.0321(3)$ \\
\hline$C(15)$ & $-0.2644(1)$ & $0.0874(2)$ & $0.1149(1)$ & $0.0294(3)$ \\
\hline$C(16)$ & $0.0227(1)$ & $0.5206(2)$ & $0.0947(1)$ & $0.0257(3)$ \\
\hline $\mathrm{C}(17)$ & $0.1239(1)$ & $0.4960(2)$ & $0.0582(1)$ & $0.0239(3)$ \\
\hline $\mathrm{C}(18)$ & $0.1196(1)$ & $0.2962(2)$ & $0.0316(1)$ & $0.0276(3)$ \\
\hline $\mathrm{C}(19)$ & $0.2088(2)$ & $0.2783(3)$ & $-0.0031(1)$ & $0.0323(3)$ \\
\hline$C(20)$ & $0.3029(2)$ & $0.4598(3)$ & $-0.0117(1)$ & $0.0341(4)$ \\
\hline $\mathrm{C}(21)$ & $0.3085(2)$ & $0.6588(3)$ & $0.0146(1)$ & $0.0300(3)$ \\
\hline$C(22)$ & $0.2196(1)$ & $0.6762(2)$ & $0.0495(1)$ & $0.0228(3)$ \\
\hline
\end{tabular}


Tabelle 1.3. Bondlengths $[\AA]$ and angles $\left[{ }^{\circ}\right]$.

\begin{tabular}{|c|c|c|c|}
\hline $\mathrm{O}(7)-\mathrm{C}(6)$ & $C(4)-C(6)$ & $149.4(2)$ & $C(14)-C(15)$ \\
\hline $\mathrm{O}(7)-\mathrm{N}(8)$ & $C(4)-C(5)$ & $151.9(2)$ & $C(16)-C(17)$ \\
\hline $\mathrm{N}(8)-\mathrm{C}(16)$ & $C(5)-C(6)$ & $148.4(2)$ & $C(17)-C(22)$ \\
\hline $\mathrm{N}(8)-\mathrm{C}(9)$ & $C(9)-C(10)$ & $150.6(2)$ & $C(17)-C(18)$ \\
\hline $\mathrm{C}(1)-\mathrm{C}(3)$ & $C(10)-C(11)$ & $138.6(2)$ & $C(18)-C(19)$ \\
\hline$C(1)-C(2)$ & $C(10)-C(15)$ & $139.0(2)$ & $C(19)-C(20)$ \\
\hline$C(2)-C(3)$ & $\mathrm{C}(11)-\mathrm{C}(12)$ & $138.8(2)$ & $C(20)-C(21)$ \\
\hline$C(3)-C(6)$ & $C(12)-C(13)$ & $137.8(2)$ & $C(21)-C(22)$ \\
\hline$C(3)-C(9)$ & $C(13)-C(14)$ & $138.2(2)$ & \\
\hline $\mathrm{C}(6)-\mathrm{O}(7)-\mathrm{N}(8)$ & $101.32(8)$ & $C(10)-C(9)-C(3)$ & $101.69(10)$ \\
\hline $\mathrm{C}(16)-\mathrm{N}(8)-\mathrm{O}(7)$ & $105.15(9)$ & $\mathrm{C}(11)-\mathrm{C}(10)-\mathrm{C}(15)$ & $118.58(11)$ \\
\hline $\mathrm{C}(16)-\mathrm{N}(8)-\mathrm{C}(9)$ & $111.90(10)$ & $\mathrm{C}(11)-\mathrm{C}(10)-\mathrm{C}(9)$ & $118.49(12)$ \\
\hline $\mathrm{O}(7)-\mathrm{N}(8)-\mathrm{C}(9)$ & $100.55(8)$ & $C(15)-C(10)-C(9)$ & $120.00(12)$ \\
\hline $\mathrm{C}(3)-\mathrm{C}(1)-\mathrm{C}(2)$ & $59.77(9)$ & $\mathrm{C}(10)-\mathrm{C}(11)-\mathrm{C}(12)$ & $121.48(11)$ \\
\hline $\mathrm{C}(3)-\mathrm{C}(2)-\mathrm{C}(1)$ & $59.89(9)$ & $\mathrm{C}(13)-\mathrm{C}(12)-\mathrm{C}(11)$ & $121.08(13)$ \\
\hline $\mathrm{C}(2)-\mathrm{C}(3)-\mathrm{C}(1)$ & $60.35(9)$ & $\mathrm{C}(12)-\mathrm{C}(13)-\mathrm{C}(14)$ & $119.88(13)$ \\
\hline $\mathrm{C}(2)-\mathrm{C}(3)-\mathrm{C}(6)$ & $122.96(12)$ & $C(13)-C(14)-C(15)$ & $119.68(12)$ \\
\hline $\mathrm{C}(1)-\mathrm{C}(3)-\mathrm{C}(6)$ & $123.83(11)$ & $C(14)-C(15)-C(10)$ & $120.43(13)$ \\
\hline $\mathrm{C}(2)-\mathrm{C}(3)-\mathrm{C}(9)$ & 119.31(11) & $\mathrm{N}(8)-\mathrm{C}(16)-\mathrm{C}(17)$ & $120.42(10)$ \\
\hline $\mathrm{C}(1)-\mathrm{C}(3)-\mathrm{C}(9)$ & $103.50(12)$ & $\mathrm{C}(22)-\mathrm{C}(17)-\mathrm{C}(18)$ & $112.45(12)$ \\
\hline $\mathrm{C}(6)-\mathrm{C}(3)-\mathrm{C}(9)$ & $59.01(10)$ & $C(22)-C(17)-C(16)$ & $118.78(12)$ \\
\hline$C(6)-C(4)-C(5)$ & $59.66(8)$ & $C(18)-C(17)-C(16)$ & $120.55(12)$ \\
\hline$C(6)-C(5)-C(4)$ & $115.11(8)$ & $\mathrm{C}(19)-\mathrm{C}(18)-\mathrm{C}(17)$ & $120.62(12)$ \\
\hline $\mathrm{O}(7)-\mathrm{C}(6)-\mathrm{C}(5)$ & $117.01(10)$ & $\mathrm{C}(20)-\mathrm{C}(19)-\mathrm{C}(18)$ & $120.46(13)$ \\
\hline $\mathrm{O}(7)-\mathrm{C}(6)-\mathrm{C}(3)$ & $61.33(11)$ & $C(21)-C(20)-C(19)$ & $120.29(13)$ \\
\hline$C(5)-C(6)-C(3)$ & $105.57(9)$ & $C(20)-C(21)-C(22)$ & $119.76(13)$ \\
\hline$C(4)-C(6)-C(3)$ & $127.46(10)$ & $\mathrm{C}(18)-\mathrm{C}(17)-\mathrm{C}(16)$ & 119.94(13) \\
\hline $\mathrm{N}(8)-\mathrm{C}(9)-\mathrm{C}(10)$ & $125.50(11)$ & $C(17)-C(22)-C(21)$ & $120.75(13)$ \\
\hline $\mathrm{N}(8)-\mathrm{C}(9)-\mathrm{C}(13)$ & $110.58(11)$ & & \\
\hline
\end{tabular}

Tabelle 1.4. Anisotropic displacement parameters $(\AA 2 \times 103)$. The anisotropic displacement factor esponent takes the form: $-2 \pi 2[\mathrm{~h} 2 \mathrm{a} * 2 \mathrm{U} 11+\ldots+2 \mathrm{hka} * \mathrm{~b} * \mathrm{U} 12]$.

\begin{tabular}{lrrrrrr}
\hline Atom & $\mathrm{U} 11$ & $\mathrm{U} 22$ & $\mathrm{U} 33$ & $\mathrm{U} 23$ & $\mathrm{U} 13$ & $\mathrm{U} 12$ \\
\hline $\mathrm{O}(7)$ & $19.1(4)$ & $27.6(5)$ & $26.2(5)$ & $4.6(4)$ & $-1.7(4)$ & $-1.6(4)$ \\
$\mathrm{N}(8)$ & $16.9(5)$ & $26.9(6)$ & $23.5(5)$ & $2.4(5)$ & $-0.9(4)$ & $-0.2(4)$
\end{tabular}




\begin{tabular}{lrrrrrr}
$\mathrm{C}(1)$ & $32.1(8)$ & $51.7(10)$ & $25.4(7)$ & $-3.6(7)$ & $5.3(6)$ & $-4.9(7)$ \\
$\mathrm{C}(2)$ & $31.9(8)$ & $41.8(9)$ & $28.8(7)$ & $5.8(7)$ & $1.0(6)$ & $-10.5(7)$ \\
$\mathrm{C}(3)$ & $24.9(7)$ & $29.6(8)$ & $21.5(7)$ & $-2.4(6)$ & $0.8(5)$ & $-4.0(6)$ \\
$\mathrm{C}(4)$ & $32.9(7)$ & $26.5(7)$ & $25.1(7)$ & $0.2(6)$ & $-0.9(6)$ & $1.3(6)$ \\
$\mathrm{C}(5)$ & $29.3(7)$ & $30.9(8)$ & $25.0(7)$ & $0.4(6)$ & $-2.4(6)$ & $0.4(6)$ \\
$\mathrm{C}(6)$ & $24.8(7)$ & $23.1(7)$ & $20.6(6)$ & $1.2(5)$ & $0.1(5)$ & $-2.7(5)$ \\
$\mathrm{C}(9)$ & $23.7(7$ & $24.2(7)$ & $25.7(7)$ & $-3.6(6)$ & $3.0(5)$ & $-0.8(5)$ \\
$\mathrm{C}(10)$ & $22.8(7)$ & $25.9(7)$ & $23.5(7)$ & $1.1(6)$ & $4.0(5)$ & $-1.1(6)$ \\
$\mathrm{C}(11)$ & $29.2(7)$ & $26.8(8)$ & $34.6(7)$ & $-4.6(6)$ & $5.9(6)$ & $0.1(6)$ \\
$\mathrm{C}(12)$ & $22.7(7)$ & $35.4(8)$ & $42.8(8)$ & $0.8(7)$ & $5.9(6)$ & $4.6(6)$ \\
$\mathrm{C}(13)$ & $22.0(7)$ & $40.4(9)$ & $33.7(8)$ & $5.8(7)$ & $-0.7(6)$ & $-4.6(6)$ \\
$\mathrm{C}(14)$ & $30.3(8)$ & $32.5(8)$ & $32.9(8)$ & $-5.1(6)$ & $-1.0(6)$ & $-6.3(6)$ \\
$\mathrm{C}(15)$ & $26.2(7)$ & $29.0(8)$ & $33.0(7)$ & $-3.7(6)$ & $2.8(6)$ & $3.1(6)$ \\
$\mathrm{C}(16)$ & $23.7(7)$ & $25.1(7)$ & $28.0(7)$ & $3.5(6)$ & $-1.0(5)$ & $2.4(6)$ \\
$\mathrm{C}(17)$ & $21.0(6)$ & $27.2(7)$ & $22.9(6)$ & $6.5(6)$ & $-3.5(5)$ & $3.2(6)$ \\
$\mathrm{C}(18)$ & $26.5(7)$ & $27.5(7)$ & $28.2(7)$ & $5.4(6)$ & $-2.9(6)$ & $-0.9(6)$ \\
$\mathrm{C}(19)$ & $35.0(8)$ & $32.9(8)$ & $26.7(7)$ & $-0.3(6)$ & $-1.4(6)$ & $5.1(7)$ \\
$\mathrm{C}(20)$ & $30.8(8)$ & $43.9(9)$ & $26.8(7)$ & $7.2(7)$ & $3.5(6)$ & $4.8(7)$ \\
$\mathrm{C}(21)$ & $28.4(7)$ & $37.4(8)$ & $34.3(8)$ & $9.9(7)$ & $2.4(6)$ & $-3.9(6)$ \\
$\mathrm{C}(22)$ & $29.7(7)$ & $27.2(7)$ & $29.0(7)$ & $3.0(6)$ & $-3.2(6)$ & $-0.2(6)$ \\
\hline
\end{tabular}


Tabelle 1.5. H-Coordinates $(\times 104)$ and isotropic displacement parameters $(\AA 2 \times 103)$.

\begin{tabular}{lrrrr}
\hline Atom & \multicolumn{1}{l}{$\mathrm{x}$} & \multicolumn{2}{l}{$\mathrm{z}$} & $\mathrm{U}(\mathrm{eq})$ \\
\hline $\mathrm{H}(1 \mathrm{~A})$ & -1296 & 3142 & 2469 & 43 \\
$\mathrm{H}(1 \mathrm{~B})$ & 282 & 1930 & 2657 & 43 \\
$\mathrm{H}(2 \mathrm{~A})$ & -344 & -1641 & 2242 & 41 \\
$\mathrm{H}(2 \mathrm{~B})$ & -1923 & -428 & 2054 & 41 \\
$\mathrm{H}(4 \mathrm{~A})$ & 2837 & -953 & 1515 & 34 \\
$\mathrm{H}(4 \mathrm{~B})$ & 1790 & -2229 & 1873 & 34 \\
$\mathrm{H}(5 \mathrm{~A})$ & 2639 & 624 & 2440 & 34 \\
$\mathrm{H}(5 \mathrm{~B})$ & 3685 & 1899 & 2081 & 34 \\
$\mathrm{H}(9 \mathrm{~A})$ & -735 & 5039 & 1698 & 29 \\
$\mathrm{H}(11 \mathrm{~A})$ & -3213 & 5799 & 1653 & 36 \\
$\mathrm{H}(12 \mathrm{~A})$ & -5585 & 5130 & 1356 & 40 \\
$\mathrm{H}(13 \mathrm{~A})$ & -6106 & 1827 & 914 & 39 \\
$\mathrm{H}(14 \mathrm{~A})$ & -4267 & -870 & 794 & 38 \\
$\mathrm{H}(15 \mathrm{~A})$ & -1901 & -236 & 1099 & 35 \\
$\mathrm{H}(16 \mathrm{~A})$ & 508 & 6615 & 1127 & 31 \\
$\mathrm{H}(16 \mathrm{~B})$ & -777 & 5451 & 815 & 31 \\
$\mathrm{H}(18 \mathrm{~A})$ & 549 & 1710 & 372 & 33 \\
$\mathrm{H}(19 \mathrm{~A})$ & 2054 & 1407 & -210 & 38 \\
$\mathrm{H}(20 \mathrm{~A})$ & 3634 & 4476 & -356 & 41 \\
$\mathrm{H}(21 \mathrm{~A})$ & 3731 & 7838 & 89 & 40 \\
$\mathrm{H}(22 \mathrm{~A})$ & 2243 & 8131 & 677 & 35 \\
\hline & & & &
\end{tabular}




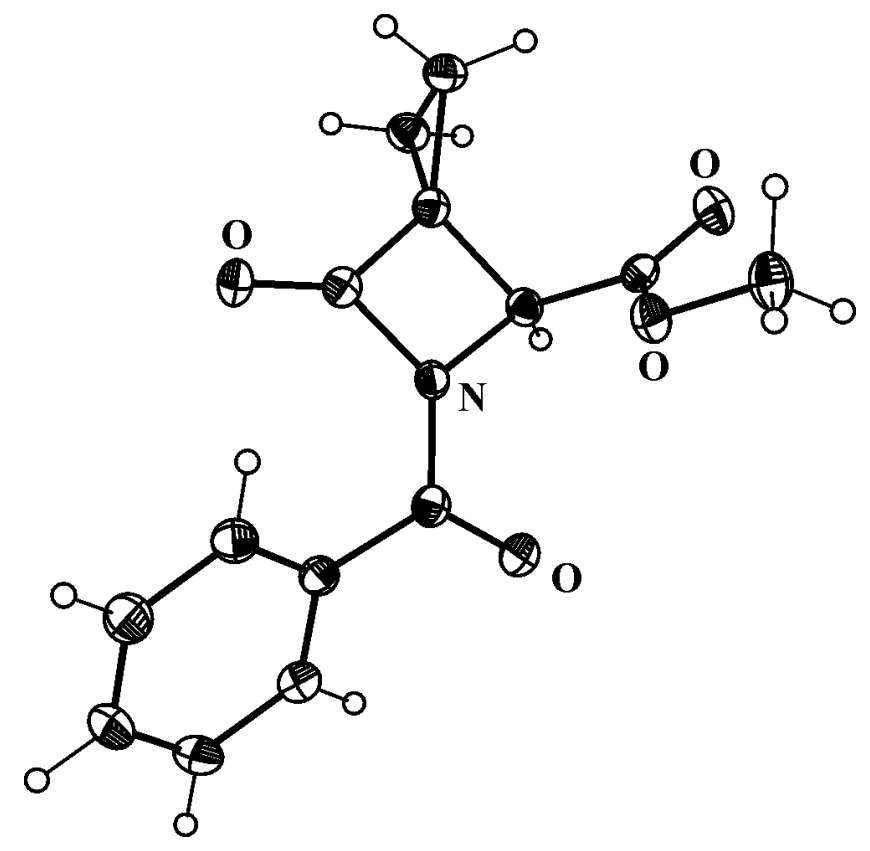

Table 2.1. Crystal data and structure refinement.

\begin{tabular}{ll}
\hline Empirical Formula & $\mathrm{C}_{14} \mathrm{H}_{13} \mathrm{NO}_{4}$ \\
Formula weight, g/mol & 259.25 \\
Crystal systesm & monoclinic \\
Space group & $\mathrm{P} 21 / \mathrm{c}$ \\
Unit cell dimensions & \\
$\mathrm{a}, \AA$ & $10.7153(6)$ \\
$\mathrm{b}, \AA$ & $8.9670(4)$ \\
$\mathrm{c}, \AA$ & $13.7210(6)$ \\
$\alpha{ }^{\circ}$ & 90 \\
$\beta,{ }^{\circ}$ & $109.056(4)$ \\
$\gamma,{ }^{\circ}$ & 90 \\
Volume, $\AA^{3}$ & $1246.12(10)$ \\
$\mathrm{Z}$ & 4 \\
Calculated density, $\mathrm{Mg} / \mathrm{m}^{3}$ & 1.382 \\
Absorption coefficient, $\mathrm{mm}^{-1}$ & 0.102 \\
F(000) & 544 \\
$\Theta-$ Range, & \\
Observed Reflections & 2.76 to 24.71 \\
Reflections collected/ unique [Rint] & 1996 \\
Data/Restraints/Parameter & $24299 / 2073[0.0326]$ \\
& $2073 / 0 / 173$ \\
&
\end{tabular}


Goof $\mathrm{F}^{2}$

$\mathrm{R}_{1}$, $\mathrm{wR}_{2}$ values [I>2 $\left.\sigma(\mathrm{I})\right]$

$\mathrm{R}_{1}, \mathrm{wR}_{2}$ values (all data)

Largest diff. peak and hole, $\mathrm{e} \cdot \AA^{-3}$
1.072

$0.0305,0.0703$

0.0316, 0.0709

0.258 and -0.170

Tabelle 2.2. Atomic coordinates and equivalent isotropic displacement parameters $(\AA 2)$. $\mathrm{U}(\mathrm{eq})$ is defined as one third of the trace of the orthogonalized Uij tensor.

\begin{tabular}{lcccc}
\hline Atom & $\mathrm{x}$ & $\mathrm{y}$ & $\mathrm{z}$ & $\mathrm{U}(\mathrm{eq})$ \\
\hline $\mathrm{N}(5)$ & $-0.1500(1)$ & $0.4959(1)$ & $0.2862(1)$ & $0.0165(2)$ \\
$\mathrm{O}(7)$ & $-0.0710(1)$ & $0.7293(1)$ & $0.3697(1)$ & $0.0217(2)$ \\
$\mathrm{O}(9)$ & $0.0280(1)$ & $0.1429(1)$ & $0.3635(1)$ & $0.0238(2)$ \\
$\mathrm{O}(10)$ & $-0.1626(1)$ & $0.2286(1)$ & $0.3783(1)$ & $0.0217(2)$ \\
$\mathrm{O}(13)$ & $-0.2897(1)$ & $0.3982(1)$ & $0.1404(1)$ & $0.0254(2)$ \\
$\mathrm{C}(1)$ & $0.1690(1)$ & $0.4701(1)$ & $0.4595(1)$ & $0.0218(3)$ \\
$\mathrm{C}(2)$ & $0.1905(1)$ & $0.5285(1)$ & $0.3638(1)$ & $0.0219(3)$ \\
$\mathrm{C}(3)$ & $0.0527(1)$ & $0.4946(1)$ & $0.3634(1)$ & $0.0176(3)$ \\
$\mathrm{C}(4)$ & $-0.0464(1)$ & $0.3820(2)$ & $0.2958(1)$ & $0.0172(2)$ \\
$\mathrm{C}(6)$ & $-0.0578(1)$ & $0.6030(1)$ & $0.3458(1)$ & $0.0172(2)$ \\
$\mathrm{C}(8)$ & $-0.0564(1)$ & $0.2374(1)$ & $0.3490(1)$ & $0.0175(2)$ \\
$\mathrm{C}(11)$ & $-0.1733(1)$ & $0.0932(1)$ & $0.4338(1)$ & $0.0271(3)$ \\
$\mathrm{C}(12)$ & $-0.2634(1)$ & $0.5031(1)$ & $0.1999(1)$ & $0.0184(3)$ \\
$\mathrm{C}(14)$ & $-0.3478(1)$ & $0.6387(1)$ & $0.1838(1)$ & $0.0194(3)$ \\
$\mathrm{C}(15)$ & $-0.4202(1)$ & $0.6751(1)$ & $0.0821(1)$ & $0.0252(3)$ \\
$\mathrm{C}(16)$ & $-0.5040(1)$ & $0.7969(2)$ & $0.0613(1)$ & $0.0323(3)$ \\
$\mathrm{C}(17$ & $-0.5181(1)$ & $0.8811(2)$ & $0.1418(1)$ & $0.0341(3)$ \\
$\mathrm{C}(18)$ & $-0.4485(1)$ & $0.8443(2)$ & $0.2428(1)$ & $0.0300(3)$ \\
$\mathrm{C}(19)$ & $-0.3624(1)$ & $0.7241(1)$ & $0.2641(1)$ & $0.0228(3)$ \\
\hline & & & &
\end{tabular}


Tabelle 2.3. Bondlengths $[\AA]$ and angles $\left[{ }^{\circ}\right]$.

$\begin{array}{lrrrr}\mathrm{N}(5)-\mathrm{C}(12) & 139.4(2) & \mathrm{O}(13)-\mathrm{C}(12)(1) & 121.6(2) & \mathrm{C}(12)-\mathrm{C}(14) \\ \mathrm{N}(5)-\mathrm{C}(6) & 142.9(2) & \mathrm{C}(1)-\mathrm{C}(2)(2) & 150.0(2) & \mathrm{C}(14)-\mathrm{C}(19) \\ \mathrm{N}(5)-\mathrm{C}(4) & 148.2(1) & \mathrm{C}(1)-\mathrm{C}(3)(2) & 150.6(2) & \mathrm{C}(14)-\mathrm{C}(15) \\ \mathrm{O}(7)-\mathrm{C}(6) & 120.0(1) & \mathrm{C}(2)-\mathrm{C}(3)(2) & 150.7(2) & \mathrm{C}(15)-\mathrm{C}(16) \\ \mathrm{O}(9)-\mathrm{C}(8) & 120.7(1) & \mathrm{C}(3)-\mathrm{C}(6)(2) & 148.9(2) & \mathrm{C}(16)-\mathrm{C}(17) \\ \mathrm{O}(10)-\mathrm{C}(8) & 132.7(1) & \mathrm{C}(3)-\mathrm{C}(4)(2) & 153.7(2) & \mathrm{C}(17)-\mathrm{C}(18) \\ \mathrm{O}(10)-\mathrm{C}(11) & 145.8(1) & \mathrm{C}(4)-\mathrm{C}(8)(2) & 150.9(2) & \mathrm{C}(18)-\mathrm{C}(19) \\ & & & \\ \mathrm{C}(12)-\mathrm{N}(5)-\mathrm{C}(6) & 134.70(9) & \mathrm{O}(7)-\mathrm{C}(6)-\mathrm{C}(3) & 136.92(11) \\ \mathrm{C}(12)-\mathrm{N}(5)-\mathrm{C}(4) & 121.83(9) & \mathrm{N}(5)-\mathrm{C}(6)-\mathrm{C}(3) & 91.03(9) \\ \mathrm{C}(6)-\mathrm{N}(5)-\mathrm{C}(4) & 93.12(8) & \mathrm{O}(9)-\mathrm{C}(8)-\mathrm{O}(10) & 125.35(10) \\ \mathrm{C}(8)-\mathrm{O}(10)-\mathrm{C}(11) & 115.44(9) & \mathrm{O}(9)-\mathrm{C}(8)-\mathrm{C}(4) & 121.01(10) \\ \mathrm{C}(2)-\mathrm{C}(1)-\mathrm{C}(3) & 60.15(7) & \mathrm{O}(10)-\mathrm{C}(8)-\mathrm{C}(4) & 113.63(9) \\ \mathrm{C}(1)-\mathrm{C}(2)-\mathrm{C}(3) & 60.12(7) & \mathrm{O}(13)-\mathrm{C}(12)-\mathrm{N}(5) & 118.70(10) \\ \mathrm{C}(6)-\mathrm{C}(3)-\mathrm{C}(1) & 128.58(10) & \mathrm{O}(13)-\mathrm{C}(12)-\mathrm{C}(14) & 122.42(10) \\ \mathrm{C}(6)-\mathrm{C}(3)-\mathrm{C}(2) & 126.51(10) & \mathrm{N}(5)-\mathrm{C}(12)-\mathrm{C}(14) & 118.87(11) \\ \mathrm{C}(1)-\mathrm{C}(3)-\mathrm{C}(2) & 59.73(8) & \mathrm{C}(19)-\mathrm{C}(14)-\mathrm{C}(15) & 119.59(10) \\ \mathrm{C}(6)-\mathrm{C}(3)-\mathrm{C}(4) & 88.60(8) & \mathrm{C}(19)-\mathrm{C}(14)-\mathrm{C}(12) & 123.46(10) \\ \mathrm{C}(1)-\mathrm{C}(3)-\mathrm{C}(4) & 130.09(10) & \mathrm{C}(15)-\mathrm{C}(14)-\mathrm{C}(12) & 116.86(12) \\ \mathrm{C}(2)-\mathrm{C}(3)-\mathrm{C}(4) & 128.16(10) & \mathrm{C}(16)-\mathrm{C}(15)-\mathrm{C}(14) & 120.11(12) \\ \mathrm{N}(5)-\mathrm{C}(4)-\mathrm{C}(8) & 117.76(9) & \mathrm{C}(15)-\mathrm{C}(16)-\mathrm{C}(17) & 119.90(12) \\ \mathrm{N}(5)-\mathrm{C}(4)-\mathrm{C}(3) & 87.19(8) & \mathrm{C}(18)-\mathrm{C}(17)-\mathrm{C}(16) & 120.36(12) \\ \mathrm{C}(8)-\mathrm{C}(4)-\mathrm{C}(3) & 114.59(9) & \mathrm{C}(17)-\mathrm{C}(18)-\mathrm{C}(19) & 120.06(12) \\ \mathrm{O}(7)-\mathrm{C}(6)-\mathrm{N}(5) & 132.05(11) & \mathrm{C}(18)-\mathrm{C}(19)-\mathrm{C}(14) & 119.95(12)\end{array}$

Tabelle 2.4. Anisotropic displacement parameters $(\AA 2 \times 103)$. The anisotropic displacement factor esponent takes the form: $-2 \pi 2[\mathrm{~h} 2 \mathrm{a} * 2 \mathrm{U} 11+\ldots+2 \mathrm{hka} * \mathrm{~b} * \mathrm{U} 12]$.

\begin{tabular}{lrrrrrr}
\hline Atom & $\mathrm{U} 11$ & $\mathrm{U} 22$ & $\mathrm{U} 33$ & $\mathrm{U} 23$ & $\mathrm{U} 13$ & $\mathrm{U} 12$ \\
\hline $\mathrm{N}(5)$ & $18.3(5)$ & $13.4(5)$ & $17.8(5)$ & $0.1(4)$ & $5.8(4)$ & $0.9(4)$ \\
$\mathrm{O}(7)$ & $24.9(4)$ & $15.6(4)$ & $26.0(4)$ & $-2.9(3)$ & $10.1(3)$ & $-0.9(3)$ \\
$\mathrm{O}(9)$ & $27.4(5)$ & $19.1(4)$ & $26.3(5)$ & $2.6(3)$ & $10.5(4)$ & $6.1(4)$ \\
$\mathrm{O}(10)$ & $23.8(4)$ & $17.4(4)$ & $26.0(4)$ & $3.6(3)$ & $11.1(3)$ & $1.0(3)$ \\
$\mathrm{O}(13)$ & $27.9(5)$ & $20.5(5)$ & $23.7(4)$ & $-4.7(4)$ & $2.8(4)$ & $0.3(4)$ \\
$\mathrm{C}(1)$ & $21.1(6)$ & $23.5(6)$ & $18.7(6)$ & $0.4(5)$ & $3.6(5)$ & $1.0(5)$ \\
$\mathrm{C}(2)$ & $17.9(6)$ & $24.0(6)$ & $23.7(6)$ & $1.8(5)$ & $6.7(5)$ & $0.5(5)$ \\
$\mathrm{C}(3)$ & $19.6(6)$ & $16.7(6)$ & $17.4(5)$ & $0.1(4)$ & $7.1(5)$ & $-0.3(4)$
\end{tabular}




\begin{tabular}{llllrrr}
$\mathrm{C}(4)$ & $17.9(5)$ & $16.5(6)$ & $17.5(5)$ & $-0.6(4)$ & $6.4(4)$ & $1.9(4)$ \\
$\mathrm{C}(6)$ & $19.9(6)$ & $17.8(6)$ & $15.8(5)$ & $1.4(4)$ & $8.2(4)$ & $-2.0(4)$ \\
$\mathrm{C}(8)$ & $19.9(6)$ & $16.8(6)$ & $14.9(5)$ & $-3.8(4)$ & $4.2(4)$ & $-0.6(5)$ \\
$\mathrm{C}(11)$ & $32.6(7)$ & $20.5(6)$ & $31.5(7)$ & $5.5(5)$ & $14.9(6)$ & $-2.5(5)$ \\
$\mathrm{C}(12)$ & $20.2(6)$ & $17.3(6)$ & $19.1(6)$ & $1.1(5)$ & $8.2(5)$ & $-2.1(5)$ \\
$\mathrm{C}(14)$ & $15.7(5)$ & $17.9(6)$ & $23.9(6)$ & $1.3(5)$ & $5.6(5)$ & $-2.3(4)$ \\
$\mathrm{C}(15)$ & $23.3(6)$ & $23.1(6)$ & $25.3(6)$ & $-1.4(5)$ & $2.7(5)$ & $-1.8(5)$ \\
$\mathrm{C}(16)$ & $25.4(7)$ & $28.9(7)$ & $32.5(7)$ & $4.0(6)$ & $-4.4(5)$ & $2.4(5)$ \\
$\mathrm{C}(17)$ & $20.8(6)$ & $25.9(7)$ & $48.7(8)$ & $-2.1(6)$ & $2.1(6)$ & $7.1(5)$ \\
$\mathrm{C}(18)$ & $22.2(6)$ & $29.0(7)$ & $38.5(7)$ & $-6.7(6)$ & $9.6(6)$ & $2.8(5)$ \\
$\mathrm{C}(19)$ & $18.7(6)$ & $24.4(6)$ & $25.6(6)$ & $-0.1(5)$ & $7.5(5)$ & $-0.5(5)$ \\
\hline
\end{tabular}

Tabelle 2.5. H-Coordinates $(\times 104)$ and isotropic displacement parameters $(\AA 2 \times 103)$.

\begin{tabular}{lrrrr}
\hline Atom & \multicolumn{1}{l}{$\mathrm{x}$} & $\mathrm{z}$ & $\mathrm{U}(\mathrm{eq})$ \\
\hline $\mathrm{H}(1 \mathrm{~A})$ & 1811 & 5403 & 5176 & 26 \\
$\mathrm{H}(1 \mathrm{~B})$ & 1956 & 3660 & 4801 & 26 \\
$\mathrm{H}(2 \mathrm{~A})$ & 2304 & 4602 & 3255 & 26 \\
$\mathrm{H}(2 \mathrm{~B})$ & 2159 & 6345 & 3630 & 26 \\
$\mathrm{H}(4 \mathrm{~A})$ & -310 & 3645 & 2286 & 21 \\
$\mathrm{H}(11 \mathrm{~A})$ & -2577 & 932 & 4473 & 41 \\
$\mathrm{H}(11 \mathrm{~B})$ & -1006 & 894 & 4994 & 41 \\
$\mathrm{H}(11 \mathrm{C})$ & -1690 & 58 & 3921 & 41 \\
$\mathrm{H}(15 \mathrm{~A})$ & -4119 & 6160 & 270 & 30 \\
$\mathrm{H}(16 \mathrm{~A})$ & -5518 & 8228 & -80 & 39 \\
$\mathrm{H}(17 \mathrm{~A})$ & -5760 & 9645 & 1274 & 41 \\
$\mathrm{H}(18 \mathrm{~A})$ & -4597 & 9015 & 2977 & 36 \\
$\mathrm{H}(19 \mathrm{~A})$ & -3134 & 7000 & 3335 & 27 \\
\hline
\end{tabular}


3. tert-butyl (2S,2'R)-2-\{[1-(tert-butoxycarbonylamino-

cyanomethyl)cyclopropylcarbonyl]amino\}-3-phenylpropionate $[(2 S, 2 ' R)-118]$

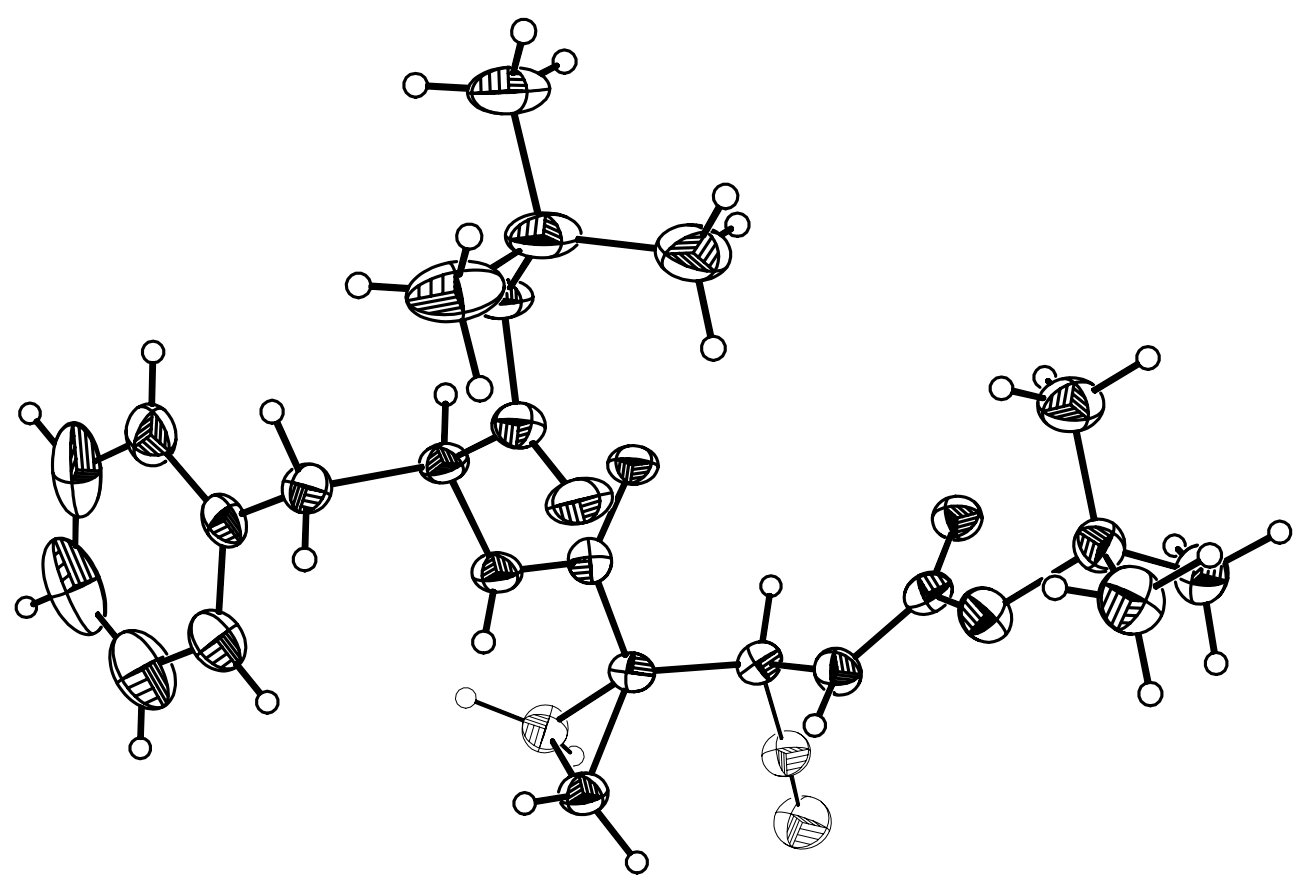

Table 3.1. Crystal data and structure refinement.

\begin{tabular}{ll}
\hline Empirical Formula & $\mathrm{C}_{24} \mathrm{H}_{33} \mathrm{~N}_{3} \mathrm{O}_{5}$ \\
Formula weight, g/mol & 443.53 \\
Crystal systesm & monoclinic \\
Space group & $\mathrm{P} 21$ \\
Unit cell dimensions & \\
$\mathrm{a}, \AA$ & $11.905(5)$ \\
$\mathrm{b}, \AA$ & $9.2517(16)$ \\
$\mathrm{c}, \AA$ & $23.371(6)$ \\
$\alpha,^{\circ}$ & 90 \\
$\beta,^{\circ}$ & $92.25(3)$ \\
$\gamma,{ }^{\circ}$ & 90 \\
Volume, $\AA^{3}$ & $2572.1(13)$ \\
$\mathrm{Z}$ & 4 \\
Calculated density, $\mathrm{Mg} / \mathrm{m}^{3}$ & 1.145 \\
Absorption coefficient, mm ${ }^{-1}$ & 0.081 \\
$\mathrm{~F}(000)$ & 952 \\
$\Theta-$ Range, & \\
Observed Reflections & 1.71 to 24.84 \\
Reflections collected/ unique [Rint] & 6613 \\
& $21983 / 8604[0.0594]$
\end{tabular}


Data/Restraints/Parameter

Goof $F^{2}$

$\mathrm{R}_{1}$, $\mathrm{wR}_{2}$ values $[\mathrm{I}>2 \sigma(\mathrm{I})]$

$\mathrm{R}_{1}$, $\mathrm{wR}_{2}$ values (all data)

Largest diff. peak and hole, $\mathrm{e} \cdot \AA^{-3}$
8604 / 1 / 597

0.994

$0.0457,0.0935$

$0.0679,0.1011$

0.247 and -0.225

Tabelle 3.2. Atomic coordinates and equivalent isotropic displacement parameters $(\AA 2)$. $\mathrm{U}(\mathrm{eq})$ is defined as one third of the trace of the orthogonalized Uij tensor.

\begin{tabular}{lcrrr}
\hline Atom & $\mathrm{x}$ & $\mathrm{y}$ & $\mathrm{z}$ & $\mathrm{U}(\mathrm{eq})$ \\
\hline $\mathrm{C}(1)$ & $0.2926(2)$ & $1.2484(3)$ & $0.5953(1)$ & $0.0373(7)$ \\
$\mathrm{C}(2)$ & $0.4022(2)$ & $1.2023(3)$ & $0.6268(1)$ & $0.0322(6)$ \\
$\mathrm{C}(3)$ & $0.4131(2)$ & $1.2750(3)$ & $0.6855(1)$ & $0.0370(7)$ \\
$\mathrm{C}(4)$ & $0.5185(2)$ & $1.2283(3)$ & $0.7195(1)$ & $0.0335(6)$ \\
$\mathrm{C}(5)$ & $0.5137(3)$ & $1.1194(3)$ & $0.7605(1)$ & $0.0434(8)$ \\
$\mathrm{C}(6)$ & $0.6112(3)$ & $1.0745(3)$ & $0.7908(1)$ & $0.0543(9)$ \\
$\mathrm{C}(7)$ & $0.7134(3)$ & $1.1356(4)$ & $0.7801(2)$ & $0.0552(9)$ \\
$\mathrm{C}(8)$ & $0.7195(3)$ & $1.2428(4)$ & $0.7400(1)$ & $0.0488(8)$ \\
$\mathrm{C}(9)$ & $0.6223(2)$ & $1.2898(3)$ & $0.7099(1)$ & $0.0388(7)$ \\
$\mathrm{O}(10)$ & $0.2077(2)$ & $1.1678(3)$ & $0.6111(1)$ & $0.0597(7)$ \\
$\mathrm{C}(11)$ & $0.0914(3)$ & $1.1904(4)$ & $0.5850(2)$ & $0.0586(10)$ \\
$\mathrm{C}(121)$ & $0.0338(7)$ & $1.0405(9)$ & $0.5996(4)$ & $0.054(3)$ \\
$\mathrm{C}(131)$ & $0.0458(9)$ & $1.3029(14)$ & $0.6050(4)$ & $0.068(3)$ \\
$\mathrm{C}(141)$ & $0.0951(7)$ & $1.1828(11)$ & $0.5153(4)$ & $0.043(2)$ \\
$\mathrm{C}(122)$ & $0.0212(6)$ & $1.1078(9)$ & $0.6276(4)$ & $0.060(3)$ \\
$\mathrm{C}(132)$ & $0.0532(7)$ & $1.3629(10)$ & $0.5981(3)$ & $0.054(2)$ \\
$\mathrm{C}(142)$ & $0.0853(9)$ & $1.1515(12)$ & $0.5302(5)$ & $0.066(3)$ \\
$\mathrm{O}(15)$ & $0.2866(2)$ & $1.3436(2)$ & $0.5604(1)$ & $0.0557(6)$ \\
$\mathrm{N}\left(1^{6}\right)$ & $0.4961(2)$ & $1.2397(3)$ & $0.5920(1)$ & $0.0301(5)$ \\
\hline
\end{tabular}

Tabelle 3.3. Bondlengths $[\AA]$ and angles $\left[{ }^{\circ}\right]$.

$\begin{array}{llllll}\mathrm{C}(1)-\mathrm{O}(15) & 120.1(4) & \mathrm{C}\left(3^{\circ}\right)-\mathrm{C}\left(6^{\circ}\right) & 151.7(4) & \mathrm{C}(22)-\mathrm{C}(23) & 135.9(6) \\ \mathrm{C}(1)-\mathrm{O}(10) & 132.0(4) & \mathrm{C}\left(3^{\circ}\right)-\mathrm{C}\left(4^{\circ}\right) & 152.3(4) & \mathrm{C}(23)-\mathrm{C}(24) & 137.3(5) \\ \mathrm{C}(1)-\mathrm{C}(2) & 153.3(4) & \mathrm{C}\left(4^{\circ}\right)-\mathrm{C}\left(5^{\circ}\right) & 149.5(5) & \mathrm{O}(25)-\mathrm{C}(26) & 135.9(3) \\ \mathrm{C}(2)-\mathrm{N}\left(1^{\circ}\right) & 145.1(3) & \mathrm{C}\left(6^{\circ}\right)-\mathrm{N}\left(7^{\circ}\right) & 145.8(4) & \mathrm{C}(26)-\mathrm{C}(28) & 137.3(5) \\ \mathrm{C}(2)-\mathrm{C}(3) & 152.7(4) & \mathrm{C}\left(6^{\circ}\right)-\mathrm{C}\left(15^{\circ}\right) & 148.5(5) & \mathrm{C}(26)-\mathrm{C}(27) & 149.6(5) \\ \mathrm{C}(3)-\mathrm{C}(4) & 152.2(4) & \mathrm{N}\left(7^{\circ}\right)-\mathrm{C}\left(8^{\circ}\right) & 134.9(4) & \mathrm{C}(26)-\mathrm{C}(29) & 151.3(4) \\ \mathrm{C}(4)-\mathrm{C}(9) & 138.7(4) & \mathrm{C}\left(8^{\circ}\right)-\mathrm{O}\left(17^{\circ}\right) & 121.8(3) & \mathrm{N}\left(18^{\circ}\right)-\mathrm{C}\left(19^{\circ}\right) & 151.2(3) \\ \mathrm{C}(4)-\mathrm{C}(5) & 139.3(4) & \mathrm{C}\left(8^{\circ}\right)-\mathrm{O}\left(9^{\circ}\right) & 134.0(3) & \mathrm{C}\left(19^{\circ}\right)-\mathrm{O}\left(31^{\circ}\right) & 151.8(3)\end{array}$




\begin{tabular}{|c|c|c|c|c|c|}
\hline$C(5)-C(6)$ & $139.9(5)$ & $\mathrm{O}\left(9^{`}\right)-\mathrm{C}\left(10^{`}\right)$ & $149.0(4)$ & $C\left(19^{\circ}\right)-C\left(20^{\circ}\right)$ & $134.9(4)$ \\
\hline$C(6)-C(7)$ & $137.4(5)$ & $\mathrm{C}\left(10^{\circ}\right)-\mathrm{C}\left(13^{\circ}\right)$ & $150.4(5)$ & $\mathrm{C}\left(20^{\circ}\right)-\mathrm{C}\left(21^{\circ}\right)$ & $122.4(4)$ \\
\hline$C(7)-C(8)$ & $136.8(4)$ & $\mathrm{C}\left(10^{\circ}\right)-\mathrm{C}\left(12^{\circ}\right)$ & 151.2(4) & $C\left(20^{\circ}\right)-C\left(22^{\circ}\right)$ & $151.2(4)$ \\
\hline$C(8)-C(9)$ & $140.0(4)$ & $\mathrm{C}\left(10^{\circ}\right)-\mathrm{C}\left(11^{\circ}\right)$ & $152.5(4)$ & $\mathrm{C}\left(20^{\circ}\right)-\mathrm{C}\left(23^{\circ}\right)$ & $150.4(3)$ \\
\hline $\mathrm{O}(10)-\mathrm{C}(11)$ & $150.5(4)$ & $\mathrm{C}\left(15^{\circ}\right)-\mathrm{N}\left(16^{6}\right)$ & $114.8(4)$ & $C\left(21^{\circ}\right)-C\left(22^{\prime}\right)$ & $151.8(4)$ \\
\hline $\mathrm{C}(11)-\mathrm{C}(131)$ & $127.1(12)$ & $\mathrm{C}(16)-\mathrm{O}(30)$ & 119.7(3) & $\mathrm{C}\left(23^{\circ}\right)-\mathrm{N}\left(24^{\circ}\right)$ & $152.3(3)$ \\
\hline$C(11)-C(142)$ & $133.0(10)$ & $\mathrm{C}(16)-\mathrm{O}(25)$ & $133.7(3)$ & $C\left(23^{\circ}\right)-C\left(32^{\circ}\right)$ & $149.4(4)$ \\
\hline $\mathrm{C}(11)-\mathrm{C}(122)$ & $152.9(8)$ & $C(16)-C(17)$ & 153.1(4) & $\mathrm{N}\left(24^{\circ}\right)-\mathrm{C}\left(25^{\circ}\right)$ & $134.3(3)$ \\
\hline $\mathrm{C}(11)-\mathrm{C}(121)$ & $159.0(9)$ & $\mathrm{C}(17)-\mathrm{N}\left(18^{\circ}\right)$ & $145.7(3)$ & $\mathrm{C}\left(25^{\circ}\right)-\mathrm{O}\left(34^{\circ}\right)$ & $122.2(3)$ \\
\hline $\mathrm{C}(11)-\mathrm{C}(141)$ & $163.4(10)$ & $\mathrm{C}(17)-\mathrm{C}(18)$ & $153.7(4)$ & $\mathrm{C}\left(25^{\circ}\right)-\mathrm{O}\left(26^{\circ}\right)$ & $134.4(3)$ \\
\hline$C(11)-C(132)$ & $169.0(10)$ & $C(18)-C(19)$ & $149.9(4)$ & $\mathrm{O}\left(26^{\circ}\right)-\mathrm{C}\left(27^{\circ}\right)$ & $147.3(3)$ \\
\hline $\mathrm{N}\left(1^{\circ}\right)-\mathrm{C}\left(2^{`}\right)$ & $133.5(4)$ & $\mathrm{C}(19)-\mathrm{C}(20)$ & $138.8(4)$ & $\mathrm{C}\left(27^{\circ}\right)-\mathrm{C}\left(28^{\circ}\right)$ & $150.9(4)$ \\
\hline $\mathrm{C}\left(2^{\circ}\right)-\mathrm{O}\left(14^{\circ}\right)$ & $123.8(3)$ & $C(19)-C(24)$ & $140.3(4)$ & $C\left(27^{\circ}\right)-C\left(30^{\circ}\right)$ & $151.2(4)$ \\
\hline $\mathrm{C}\left(2^{\circ}\right)-\mathrm{C}\left(3^{\circ}\right)$ & $149.9(4)$ & $\mathrm{C}(20)-\mathrm{C}(21)$ & $140.5(5)$ & $\mathrm{C}\left(27^{\circ}\right)-\mathrm{C}\left(29^{\circ}\right)$ & $152.5(4)$ \\
\hline$C\left(3^{\circ}\right)-C\left(5^{\circ}\right)$ & $150.1(4)$ & $C(21)-C(22)$ & $139.3(6)$ & $\mathrm{C}\left(32^{\circ}\right)-\mathrm{N}\left(33^{\circ}\right)$ & $114.8(4)$ \\
\hline
\end{tabular}

$\begin{array}{lllr}\mathrm{O}(15)-\mathrm{C}(1)-\mathrm{O}(10) & 125.3(3) & \mathrm{O}\left(14^{\circ}\right)-\mathrm{C}\left(2^{\circ}\right)-\mathrm{C}\left(3^{\circ}\right) & 120.4(6) \\ \mathrm{O}(15)-\mathrm{C}(1)-\mathrm{C}(2) & 123.9(3) & \mathrm{N}\left(1^{\circ}\right)-\mathrm{C}\left(2^{\circ}\right)-\mathrm{C}\left(3^{\circ}\right) & 117.7(6) \\ \mathrm{O}(10)-\mathrm{C}(1)-\mathrm{C}(2) & 110.8(3) & \mathrm{C}\left(2^{\circ}\right)-\mathrm{C}\left(3^{\circ}\right)-\mathrm{C}\left(5^{\circ}\right) & 122.4(6) \\ \mathrm{N}\left(1^{\circ}\right)-\mathrm{C}(2)-\mathrm{C}(3) & 111.0(2) & \mathrm{C}\left(2^{\circ}\right)-\mathrm{C}\left(3^{\circ}\right)-\mathrm{C}\left(6^{\circ}\right) & 111.0(6) \\ \mathrm{N}\left(1^{\circ}\right)-\mathrm{C}(2)-\mathrm{C}(1) & 108.9(2) & \mathrm{C}\left(5^{\circ}\right)-\mathrm{C}\left(3^{\circ}\right)-\mathrm{C}\left(6^{\circ}\right) & 119.2(6) \\ \mathrm{C}(3)-\mathrm{C}(2)-\mathrm{C}(1) & 110.5(2) & \mathrm{C}\left(2^{\circ}\right)-\mathrm{C}\left(3^{\circ}\right)-\mathrm{C}\left(4^{\circ}\right) & 116.3(6) \\ \mathrm{C}(4)-\mathrm{C}(3)-\mathrm{C}(2) & 112.5(2) & \mathrm{C}\left(5^{\circ}\right)-\mathrm{C}\left(3^{\circ}\right)-\mathrm{C}\left(4^{\circ}\right) & 59.2(6) \\ \mathrm{C}(9)-\mathrm{C}(4)-\mathrm{C}(5) & 118.0(3) & \mathrm{C}\left(6^{\circ}\right)-\mathrm{C}\left(3^{\circ}\right)-\mathrm{C}\left(4^{\circ}\right) & 119.8(6) \\ \mathrm{C}(9)-\mathrm{C}(4)-\mathrm{C}(3) & 121.4(2) & \mathrm{C}\left(5^{\circ}\right)-\mathrm{C}\left(4^{\circ}\right)-\mathrm{C}\left(3^{\circ}\right) & 56.66(6) \\ \mathrm{C}(5)-\mathrm{C}(4)-\mathrm{C}(3) & 120.6(3) & \mathrm{C}\left(4^{\circ}\right)-\mathrm{C}\left(5^{\circ}\right)-\mathrm{C}\left(3^{\circ}\right) & 61.11(6) \\ \mathrm{C}(4)-\mathrm{C}(5)-\mathrm{C}(6) & 120.5(3) & \mathrm{N}\left(7^{\circ}\right)-\mathrm{C}\left(6^{\circ}\right)-\mathrm{C}\left(15^{\circ}\right) & 110.8(6) \\ \mathrm{C}(7)-\mathrm{C}(6)-\mathrm{C}(5) & 120.6(3) & \mathrm{N}\left(7^{\circ}\right)-\mathrm{C}\left(6^{\circ}\right)-\mathrm{C}\left(3^{\circ}\right) & 110.2(6) \\ \mathrm{C}(8)-\mathrm{C}(7)-\mathrm{C}(6) & 119.6(3) & \mathrm{C}\left(15^{\circ}\right)-\mathrm{C}\left(6^{\circ}\right)-\mathrm{C}\left(3^{\circ}\right) & 111.1(6) \\ \mathrm{C}(7)-\mathrm{C}(8)-\mathrm{C}(9) & 120.3(3) & \mathrm{C}\left(8^{\circ}\right)-\mathrm{N}\left(7^{\circ}\right)-\mathrm{C}\left(6^{\circ}\right) & 121.3(3) \\ \mathrm{C}(4)-\mathrm{C}(9)-\mathrm{C}(8) & 121.0(3) & \mathrm{O}\left(17^{\circ}\right)-\mathrm{C}\left(8^{\circ}\right)-\mathrm{N}\left(7^{\circ}\right) & 124.1(3) \\ \mathrm{C}(1)-\mathrm{O}(10)-\mathrm{C}(11) & 120.8(2) & \mathrm{O}\left(9^{\circ}\right)-\mathrm{C}\left(8^{\circ}\right)-\mathrm{N}\left(7^{\circ}\right) & 110.0(2) \\ \mathrm{C}(131)-\mathrm{C}(11)-\mathrm{C}(142) & 124.6(7) & \mathrm{C}\left(8^{\circ}\right)-\mathrm{O}\left(9^{\circ}\right)-\mathrm{C}\left(10^{\circ}\right) & 121.3(2) \\ \mathrm{C}(131)-\mathrm{C}(11)-\mathrm{O}(10) & 111.4(6) & \mathrm{O}\left(9^{\circ}\right)-\mathrm{C}\left(10^{\circ}\right)-\mathrm{C}\left(13^{\circ}\right) & 110.6(2) \\ \mathrm{C}(142)-\mathrm{C}(11)-\mathrm{O}(10) & 111.5(5) & \mathrm{O}\left(9^{\circ}\right)-\mathrm{C}\left(10^{\circ}\right)-\mathrm{C}\left(12^{\circ}\right) & 109.7(3) \\ \mathrm{C}(131)-\mathrm{C}(11)-\mathrm{C}(122) & 85.3(6) & \mathrm{C}\left(13^{\circ}\right)-\mathrm{C}\left(10^{\circ}\right)-\mathrm{C}\left(12^{\circ}\right) & 113.5(3) \\ \mathrm{C}(142)-\mathrm{C}(11)-\mathrm{C}(122) & 118.8(6) & \mathrm{O}\left(9^{\circ}\right)-\mathrm{C}\left(10^{\circ}\right)-\mathrm{C}\left(11^{\circ}\right) & 100.9(2) \\ \mathrm{O}(10)-\mathrm{C}(11)-\mathrm{C}(122) & 100.7(3) & \mathrm{C}\left(13^{\circ}\right)-\mathrm{C}\left(10^{\circ}\right)-\mathrm{C}\left(11^{\circ}\right) & 110.5(3)\end{array}$




\begin{tabular}{|c|c|c|c|}
\hline$C(131)-C(11)-C(121)$ & $116.2(6)$ & $\mathrm{C}\left(12^{\circ}\right)-\mathrm{C}\left(10^{\circ}\right)-\mathrm{C}\left(11^{\circ}\right)$ & $111.0(3)$ \\
\hline$C(142)-C(11)-C(121)$ & $87.9(6)$ & $\mathrm{N}\left(16^{\circ}\right)-\mathrm{C}\left(15^{\circ}\right)-\mathrm{C}\left(6^{\circ}\right)$ & $178.7(4)$ \\
\hline $\mathrm{O}(10)-\mathrm{C}(11)-\mathrm{C}(121)$ & $101.0(4)$ & $\mathrm{O}(30)-\mathrm{C}(16)-\mathrm{O}(25)$ & $126.8(3)$ \\
\hline$C(122)-C(11)-C(121)$ & $34.2(3)$ & $\mathrm{O}(30)-\mathrm{C}(16)-\mathrm{C}(17)$ & $123.4(2)$ \\
\hline$C(131)-C(11)-C(141)$ & $115.5(6)$ & $\mathrm{O}(25)-\mathrm{C}(16)-\mathrm{C}(17)$ & $109.7(2)$ \\
\hline$C(142)-C(11)-C(141)$ & $14.0(6)$ & $\mathrm{N}\left(18^{6}\right)-\mathrm{C}(17)-\mathrm{C}(16)$ & $110.1(2)$ \\
\hline $\mathrm{O}(10)-\mathrm{C}(11)-\mathrm{C}(141)$ & $109.7(4)$ & $\mathrm{N}\left(18^{6}\right)-\mathrm{C}(17)-\mathrm{C}(18)$ & $110.4(2)$ \\
\hline$C(122)-C(11)-C(141)$ & $131.6(5)$ & $\mathrm{C}(16)-\mathrm{C}(17)-\mathrm{C}(18)$ & $107.2(2)$ \\
\hline$C(121)-C(11)-C(141)$ & $101.9(5)$ & $\mathrm{C}(19)-\mathrm{C}(18)-\mathrm{C}(17)$ & $115.4(2)$ \\
\hline $\mathrm{C}(131)-\mathrm{C}(11)-\mathrm{C}(132)$ & $16.0(6)$ & $\mathrm{C}(20)-\mathrm{C}(19)-\mathrm{C}(24)$ & $118.0(3)$ \\
\hline$C(142)-C(11)-C(132)$ & $115.1(6)$ & $\mathrm{C}(20)-\mathrm{C}(19)-\mathrm{C}(18)$ & $121.8(3)$ \\
\hline $\mathrm{O}(10)-\mathrm{C}(11)-\mathrm{C}(132)$ & $107.9(4)$ & $C(24)-C(19)-C(18)$ & $120.2(3)$ \\
\hline$C(122)-C(11)-C(132)$ & $101.3(5)$ & $C(19)-C(20)-C(21)$ & $120.1(4)$ \\
\hline$C(121)-C(11)-C(132)$ & $131.6(5)$ & $\mathrm{C}(22)-\mathrm{C}(21)-\mathrm{C}(20)$ & $119.8(3)$ \\
\hline$C(141)-C(11)-C(132)$ & $103.8(5)$ & $C(23)-C(22)-C(21)$ & $120.3(3)$ \\
\hline $\mathrm{C}\left(2^{\circ}\right)-\mathrm{N}\left(1^{\circ}\right)-\mathrm{C}(2)$ & $121.2(3)$ & $\mathrm{C}(22)-\mathrm{C}(23)-\mathrm{C}(24)$ & $120.0(4)$ \\
\hline $\mathrm{O}\left(14^{\circ}\right)-\mathrm{C}\left(2^{\circ}\right)-\mathrm{N}\left(1^{\circ}\right)$ & $121.9(3)$ & $C(23)-C(24)-C(19)$ & $121.8(3)$ \\
\hline $\mathrm{C}(16)-\mathrm{O}(25)-\mathrm{C}(26)$ & $110.6(3)$ & $\mathrm{C}\left(22^{\circ}\right)-\mathrm{C}\left(21^{\circ}\right)-\mathrm{C}\left(20^{\circ}\right)$ & $60.83(17)$ \\
\hline $\mathrm{O}(25)-\mathrm{C}(26)-\mathrm{C}(28)$ & $113.8(3)$ & $\mathrm{C}\left(21^{\circ}\right)-\mathrm{C}\left(22^{\circ}\right)-\mathrm{C}\left(20^{\circ}\right)$ & $59.93(16)$ \\
\hline $\mathrm{O}(25)-\mathrm{C}(26)-\mathrm{C}(27)$ & $101.0(2)$ & $\mathrm{N}\left(24^{\circ}\right)-\mathrm{C}\left(23^{\circ}\right)-\mathrm{C}\left(32^{\circ}\right)$ & $111.0(2)$ \\
\hline$C(28)-C(26)-C(27)$ & $111.0(3)$ & $\mathrm{N}\left(24^{\circ}\right)-\mathrm{C}\left(23^{\circ}\right)-\mathrm{C}\left(20^{\circ}\right)$ & $109.3(2)$ \\
\hline $\mathrm{O}(25)-\mathrm{C}(26)-\mathrm{C}(29)$ & 111.2(3) & $\mathrm{C}\left(32^{\circ}\right)-\mathrm{C}\left(23^{\circ}\right)-\mathrm{C}\left(20^{\circ}\right)$ & $110.4(2)$ \\
\hline$C(28)-C(26)-C(29)$ & $120.3(2)$ & $\mathrm{C}\left(25^{\circ}\right)-\mathrm{N}\left(24^{\circ}\right)-\mathrm{C}\left(23^{\circ}\right)$ & $122.2(2)$ \\
\hline$C(27)-C(26)-C(29)$ & $122.7(2)$ & $\mathrm{O}\left(34^{\circ}\right)-\mathrm{C}\left(25^{\circ}\right)-\mathrm{N}\left(24^{\circ}\right)$ & $125.4(2)$ \\
\hline $\mathrm{C}\left(19^{\triangleleft}\right)-\mathrm{N}\left(18^{\circ}\right)-\mathrm{C}(17)$ & $120.3(2)$ & $\mathrm{O}\left(34^{\circ}\right)-\mathrm{C}\left(25^{\circ}\right)-\mathrm{O}\left(26^{\circ}\right)$ & $125.5(2)$ \\
\hline $\mathrm{O}\left(31^{\circ}\right)-\mathrm{C}\left(19^{\circ}\right)-\mathrm{N}\left(18^{\circ}\right)$ & $122.7(2)$ & $\mathrm{N}\left(24^{\circ}\right)-\mathrm{C}\left(25^{\circ}\right)-\mathrm{O}\left(26^{\circ}\right)$ & $109.0(2)$ \\
\hline $\mathrm{O}\left(31^{\circ}\right)-\mathrm{C}\left(19^{\triangleleft}\right)-\mathrm{C}\left(20^{\circ}\right)$ & $120.4(2)$ & $\mathrm{C}\left(25^{\circ}\right)-\mathrm{O}\left(26^{\circ}\right)-\mathrm{C}\left(27^{\circ}\right)$ & $122.3(2)$ \\
\hline $\mathrm{N}\left(18^{\circ}\right)-\mathrm{C}\left(19^{\circ}\right)-\mathrm{C}\left(20^{\circ}\right)$ & $116.9(2)$ & $\mathrm{O}\left(26^{\circ}\right)-\mathrm{C}\left(27^{\circ}\right)-\mathrm{C}\left(28^{\circ}\right)$ & $102.0(2)$ \\
\hline $\mathrm{C}\left(21^{\circ}\right)-\mathrm{C}\left(20^{\circ}\right)-\mathrm{C}\left(19^{\circ}\right)$ & $122.4(2)$ & $\mathrm{O}\left(26^{\circ}\right)-\mathrm{C}\left(27^{\circ}\right)-\mathrm{C}\left(30^{\circ}\right)$ & $109.7(2)$ \\
\hline$C\left(21^{\circ}\right)-C\left(20^{\circ}\right)-C\left(22^{\circ}\right)$ & $59.24(17)$ & $\mathrm{C}\left(28^{\circ}\right)-\mathrm{C}\left(27^{\circ}\right)-\mathrm{C}\left(30^{\circ}\right)$ & $111.3(2)$ \\
\hline $\mathrm{C}\left(19^{\circ}\right)-\mathrm{C}\left(20^{\circ}\right)-\mathrm{C}\left(22^{\circ}\right)$ & $116.0(2)$ & $\mathrm{O}\left(26^{\circ}\right)-\mathrm{C}\left(27^{\circ}\right)-\mathrm{C}\left(29^{\circ}\right)$ & $110.5(2)$ \\
\hline$C\left(21^{\circ}\right)-C\left(20^{\circ}\right)-C\left(23^{\circ}\right)$ & $117.9(2)$ & $\mathrm{C}\left(28^{\circ}\right)-\mathrm{C}\left(27^{\circ}\right)-\mathrm{C}\left(29^{\circ}\right)$ & $110.2(2)$ \\
\hline$C\left(19^{\circ}\right)-C\left(20^{\circ}\right)-C\left(23^{\circ}\right)$ & $111.5(2)$ & $\mathrm{C}\left(30^{\circ}\right)-\mathrm{C}\left(27^{\circ}\right)-\mathrm{C}\left(29^{\circ}\right)$ & $112.7(2)$ \\
\hline$C\left(22^{\circ}\right)-C\left(20^{\circ}\right)-C\left(23^{\circ}\right)$ & $120.7(2)$ & $\mathrm{N}\left(33^{\circ}\right)-\mathrm{C}\left(32^{\circ}\right)-\mathrm{C}\left(23^{\circ}\right)$ & $177.7(3)$ \\
\hline
\end{tabular}


Tabelle 3.4. Anisotropic displacement parameters $(\AA 2 \times 103)$. The anisotropic displacement factor esponent takes the form: $-2 \pi 2[\mathrm{~h} 2 \mathrm{a} * 2 \mathrm{U} 11+\ldots+2 \mathrm{hka} * \mathrm{~b} * \mathrm{U} 12]$.

\begin{tabular}{|c|c|c|c|c|c|c|}
\hline Atom & U11 & U22 & U33 & $\mathrm{U} 23$ & U13 & U12 \\
\hline $\mathrm{C}(1)$ & $26.3(15)$ & $38.2(17)$ & $47.1(17)$ & $1.7(15)$ & $-3.4(12)$ & $-3.9(13)$ \\
\hline$C(2)$ & $20.6(14)$ & $35.7(16)$ & $40.4(15)$ & $3.9(12)$ & $0.9(11)$ & $-4.4(12)$ \\
\hline$C(3)$ & $30.1(16)$ & $41.7(17)$ & $39.4(16)$ & $1.4(14)$ & $3.8(12)$ & $-4.0(13)$ \\
\hline$C(4)$ & $39.9(17)$ & $30.5(14)$ & $29.9(14)$ & $1.0(12)$ & $0(12)$ & $-2.9(13)$ \\
\hline$C(5)$ & $60(2)$ & $37.5(17)$ & $33.5(16)$ & $1.0(13)$ & $6.7(15)$ & $-9.3(15)$ \\
\hline$C(6)$ & $91(3)$ & $36.4(18)$ & $34.7(17)$ & $9.9(14)$ & $-9.8(18)$ & $-1.6(18)$ \\
\hline$C(7)$ & $61(2)$ & $51(2)$ & $52(2)$ & $7.2(17)$ & $-26.6(17)$ & $1.9(18)$ \\
\hline $\mathrm{C}(8)$ & $45.8(19)$ & $52.1(19)$ & $46.8(18)$ & $9.3(16)$ & $-19.1(14)$ & $-5.7(16)$ \\
\hline$C(9)$ & $43.5(18)$ & $37.0(16)$ & $35.0(15)$ & $8.8(13)$ & $-9.2(13)$ & $-5.9(14)$ \\
\hline $\mathrm{O}(10)$ & $19.7(11)$ & $82.5(17)$ & $76.0(16)$ & $43.5(14)$ & $-10.1(11)$ & $-13.6(11)$ \\
\hline $\mathrm{C}(11)$ & $23.2(17)$ & $77(3)$ & $75(2)$ & $34(2)$ & $-8.5(16)$ & $-11.1(17)$ \\
\hline $\mathrm{O}(15)$ & $33.8(12)$ & $50.1(13)$ & $82.3(16)$ & $25.4(13)$ & $-11.4(11)$ & $-9.4(10)$ \\
\hline $\mathrm{N}\left(1^{\circ}\right)$ & 27.1(13) & $25.6(13)$ & $37.5(13)$ & $-2.1(11)$ & $-1.0(10)$ & $-6.5(10)$ \\
\hline$C\left(2^{\circ}\right)$ & $26.5(15)$ & $26.6(14)$ & $32.1(14)$ & $4.6(12)$ & $-10.6(11)$ & $2.9(12)$ \\
\hline$C\left(3^{\circ}\right)$ & $24.6(14)$ & $32.2(15)$ & $33.1(15)$ & $1.4(12)$ & $-3.5(12)$ & $2.1(11)$ \\
\hline$C\left(4^{\circ}\right)$ & $23.0(16)$ & $78(2)$ & $39.3(17)$ & $5.0(16)$ & $-6.6(13)$ & $-1.9(16)$ \\
\hline$C\left(5^{\circ}\right)$ & $35.0(17)$ & 49.1(18) & $44.0(17)$ & $-5.1(14)$ & $3.9(14)$ & $-13.0(14)$ \\
\hline$C\left(6^{\circ}\right)$ & $33.7(16)$ & $32.8(15)$ & $34.6(15)$ & $0.9(12)$ & $-2.2(12)$ & $8.4(12)$ \\
\hline $\mathrm{N}\left(7^{\circ}\right)$ & $51.2(17)$ & $27.9(14)$ & $39.3(14)$ & $-5.4(12)$ & $-18.3(12)$ & $11.3(12)$ \\
\hline$C\left(8^{\circ}\right)$ & $44.5(18)$ & $34.9(17)$ & $29.8(15)$ & $0.4(13)$ & $-5.9(13)$ & $12.7(14)$ \\
\hline $\mathrm{O}\left(9^{‘}\right)$ & $51.5(13)$ & $33.5(11)$ & $46.5(12)$ & $-7.9(9)$ & $-19.3(10)$ & $15.5(10)$ \\
\hline$C\left(10^{\circ}\right)$ & $43.5(18)$ & $43.0(17)$ & $42.8(16)$ & $-2.3(15)$ & $-17.8(14)$ & $14.3(15)$ \\
\hline$C\left(11^{\circ}\right)$ & $69(3)$ & $59(2)$ & $69(2)$ & $-8.5(19)$ & $-30.2(19)$ & $35(2)$ \\
\hline$C\left(12^{\prime}\right)$ & $63(2)$ & 49.3(19) & $38.2(17)$ & $2.7(15)$ & $-11.5(15)$ & $6.9(16)$ \\
\hline$C\left(13^{\circ}\right)$ & $47(2)$ & $62(2)$ & $55(2)$ & $2.0(17)$ & $-8.5(17)$ & $14.4(17)$ \\
\hline$C\left(14^{\prime}\right)$ & $37.5(12)$ & $29.9(11)$ & $47.2(12)$ & $-2.6(9)$ & $-6.1(9)$ & $-6.7(9)$ \\
\hline$C\left(15^{\circ}\right)$ & $55(2)$ & $49.2(19)$ & $36.4(17)$ & $6.4(14)$ & $0.2(17)$ & $15.7(16)$ \\
\hline $\mathrm{N}\left(16^{\circ}\right)$ & $66(2)$ & $83(2)$ & $57.2(18)$ & $20.3(17)$ & $20.5(17)$ & $16.3(19)$ \\
\hline $\mathrm{O}\left(17^{\circ}\right)$ & $44.0(12)$ & $30.1(11)$ & $37.8(11)$ & $-5.5(9)$ & $-10.4(9)$ & $9.0(9)$ \\
\hline$C(16)$ & $30.7(16)$ & $27.9(15)$ & $36.8(16)$ & $6.6(12)$ & $2.9(12)$ & $4.3(12)$ \\
\hline $\mathrm{C}(17)$ & $18.3(13)$ & $27.6(13)$ & $37.1(15)$ & $7.8(12)$ & $0.2(11)$ & $2.7(11)$ \\
\hline $\mathrm{C}(18)$ & $21.5(15)$ & $32.3(15)$ & $37.6(16)$ & $5.5(12)$ & $1.5(11)$ & $-2.7(11)$ \\
\hline $\mathrm{C}(19)$ & $32.4(15)$ & 29.1(14) & $32.8(14)$ & $6.7(14)$ & $6.0(12)$ & $-7.5(12)$ \\
\hline$C(20)$ & $60(2)$ & $31.9(16)$ & $57(2)$ & $7.1(2)$ & $25.5(17)$ & $1.1(15)$ \\
\hline $\mathrm{C}(21)$ & $11.0(4)$ & $42(2)$ & 71(3) & $-18(2)$ & $57(3)$ & $-26(2)$ \\
\hline
\end{tabular}




\begin{tabular}{|c|c|c|c|c|c|c|}
\hline $\mathrm{C}(22)$ & $11.2(4)$ & $75(3)$ & $39(2)$ & $-6(19)$ & $11(2)$ & $-48(3)$ \\
\hline$C(23)$ & $77(3)$ & $71(3)$ & $37.6(19)$ & $2.5(14)$ & $-5.8(18)$ & $-22(2)$ \\
\hline$C(24)$ & $47(2)$ & $40.1(16)$ & $37.3(17)$ & $3.1(8)$ & $-0.9(14)$ & $-9.3(15)$ \\
\hline $\mathrm{O}(25)$ & $30.8(10)$ & $34.0(10)$ & $33.3(10)$ & $1.9(14)$ & $-7.3(8)$ & $13.2(8)$ \\
\hline$C(26)$ & $49(2)$ & $46.0(18)$ & $35.8(16)$ & $-4.0(14)$ & $-16.2(13)$ & $21.9(15)$ \\
\hline$C(27)$ & $95(3)$ & $85(3)$ & $31.5(17)$ & $1.9(18)$ & $-2.7(18)$ & $53(2)$ \\
\hline$C(28)$ & $51(2)$ & $46.6(19)$ & $68(2)$ & $-15.1(17)$ & $-28.2(17)$ & $11.6(16)$ \\
\hline$C(29)$ & $57(2)$ & $48.5(19)$ & $45.2(18)$ & $-5.7(15)$ & $-17.4(15)$ & $26.6(16)$ \\
\hline $\mathrm{O}(30)$ & $41.4(13)$ & $38.1(12)$ & $41.3(11)$ & $-1.9(9)$ & $-4.4(9)$ & $17.6(10)$ \\
\hline $\mathrm{N}\left(18^{\circ}\right)$ & $20.3(12)$ & $25.6(12)$ & $37.5(13)$ & $8.1(10)$ & $-0.4(9)$ & $1.0(10)$ \\
\hline$C\left(19^{\prime}\right)$ & $23.2(14)$ & $25.6(14)$ & $23.5(13)$ & $-1.9(11)$ & $-0.7(10)$ & $-2.8(11)$ \\
\hline$C\left(20^{\circ}\right)$ & $22.4(13)$ & 21.1(12) & $27.0(13)$ & $1.8(11)$ & $-2.4(10)$ & $-0.6(10)$ \\
\hline$C\left(21^{\circ}\right)$ & 24.1(14) & $29.4(14)$ & $35.1(14)$ & $4.2(12)$ & $-1.0(11)$ & $2.8(12)$ \\
\hline$C\left(22^{\prime}\right)$ & $27.4(15)$ & $41.2(16)$ & $26.0(14)$ & $-0.4(12)$ & $-2.6(11)$ & $1.8(12)$ \\
\hline$C\left(23^{\circ}\right)$ & $20.7(13)$ & $21.8(13)$ & $30.1(14)$ & $-3.0(11)$ & $0.1(10)$ & $-2.0(10)$ \\
\hline $\mathrm{N}\left(24^{6}\right)$ & $33.5(13)$ & $21.3(12)$ & $30.6(13)$ & $1.4(10)$ & $3.7(10)$ & $-3.3(10)$ \\
\hline$C\left(25^{\circ}\right)$ & $20.9(13)$ & $24.6(14)$ & $33.7(15)$ & $-1.1(12)$ & $0.9(10)$ & $2.0(11)$ \\
\hline $\mathrm{O}\left(26^{\circ}\right)$ & $43.8(12)$ & $28.6(10)$ & $28.6(10)$ & $-2.3(8)$ & $-0.3(8)$ & $-3.0(9)$ \\
\hline$C\left(27^{\circ}\right)$ & $31.6(16)$ & $37.3(16)$ & $28.8(15)$ & $-0.9(12)$ & $-0.6(12)$ & $0.8(12)$ \\
\hline$C\left(28^{\circ}\right)$ & $53(2)$ & $43.6(18)$ & $41.3(18)$ & $-7.0(14)$ & $-3.7(15)$ & $-3.4(15)$ \\
\hline$C\left(29^{\circ}\right)$ & $41.9(18)$ & $45.5(18)$ & $42.8(17)$ & $-2.1(14)$ & $-9.1(14)$ & $7.2(15)$ \\
\hline$C\left(30^{\circ}\right)$ & $42.2(18)$ & $39.8(17)$ & $38.5(16)$ & $-3.1(13)$ & $5.6(13)$ & $-1.4(14)$ \\
\hline $\mathrm{O}\left(31^{\circ}\right)$ & $27.2(10)$ & $23.9(10)$ & $39.0(10)$ & $7.9(8)$ & $1.5(8)$ & $3.3(8)$ \\
\hline$C\left(32^{\circ}\right)$ & $23.3(16)$ & $30.0(14)$ & $39.0(15)$ & $0.8(12)$ & $0.5(12)$ & $-3.0(12)$ \\
\hline $\mathrm{N}\left(33^{\circ}\right)$ & $29.3(15)$ & $48.6(16)$ & $56.9(16)$ & 7.1(13) & $-0.1(12)$ & $-3.1(12)$ \\
\hline $\mathrm{O}\left(34^{\circ}\right)$ & $30.8(10)$ & $25.0(10)$ & $34.4(10)$ & $1.5(8)$ & $0.9(8)$ & $1.0(8)$ \\
\hline
\end{tabular}

Tabelle 3.5. H-Coordinates $(\times 104)$ and isotropic displacement parameters $(\AA 2 \times 103)$.

\begin{tabular}{lclrr}
\hline Atom & x & $y$ & $z$ & $\mathrm{U}(\mathrm{eq})$ \\
\hline $\mathrm{H}(2 \mathrm{~A})$ & 4011 & 10951 & 6323 & 39 \\
$\mathrm{H}(3 \mathrm{~A})$ & 4147 & 13812 & 6802 & 44 \\
$\mathrm{H}(3 \mathrm{~B})$ & 3463 & 12511 & 7075 & 44 \\
$\mathrm{H}(5 \mathrm{~A})$ & 4437 & 10753 & 7679 & 52 \\
$\mathrm{H}(6 \mathrm{~A})$ & 6067 & 10010 & 8190 & 65 \\
$\mathrm{H}(7 \mathrm{~A})$ & 7795 & 11037 & 8005 & 66 \\
$\mathrm{H}(8 \mathrm{~A})$ & 7900 & 12855 & 7325 & 59 \\
$\mathrm{H}(9 \mathrm{~A})$ & 6275 & 13650 & 6824 & 47 \\
$\mathrm{H}(12 \mathrm{~A})$ & 354 & 10269 & 6412 & 82
\end{tabular}




\begin{tabular}{|c|c|c|c|c|}
\hline $\mathrm{H}(12 \mathrm{~B})$ & 748 & 9615 & 5819 & 82 \\
\hline $\mathrm{H}(12 \mathrm{C})$ & -444 & 10408 & 5847 & 82 \\
\hline $\mathrm{H}(13 \mathrm{~A})$ & 802 & 13891 & 5887 & 102 \\
\hline $\mathrm{H}(13 \mathrm{~B})$ & 569 & 13042 & 6468 & 102 \\
\hline $\mathrm{H}(13 \mathrm{C})$ & -349 & 13021 & 5949 & 102 \\
\hline $\mathrm{H}(14 \mathrm{~A})$ & 185 & 11897 & 4986 & 65 \\
\hline $\mathrm{H}(14 \mathrm{~B})$ & 1288 & 10910 & 5040 & 65 \\
\hline $\mathrm{H}(14 \mathrm{C})$ & 1403 & 12632 & 5015 & 65 \\
\hline $\mathrm{H}(12 \mathrm{D})$ & 256 & 11569 & 6647 & 89 \\
\hline $\mathrm{H}(12 \mathrm{E})$ & 502 & 10091 & 6319 & 89 \\
\hline $\mathrm{H}(12 \mathrm{~F})$ & -573 & 11044 & 6133 & 89 \\
\hline $\mathrm{H}(13 \mathrm{D})$ & -266 & 13757 & 5875 & 81 \\
\hline $\mathrm{H}(13 \mathrm{E})$ & 982 & 14288 & 5755 & 81 \\
\hline $\mathrm{H}(13 \mathrm{~F})$ & 659 & 13842 & 6389 & 81 \\
\hline $\mathrm{H}(14 \mathrm{D})$ & 71 & 11567 & 5157 & 100 \\
\hline $\mathrm{H}(14 \mathrm{E})$ & 1130 & 10523 & 5265 & 100 \\
\hline $\mathrm{H}(14 \mathrm{~F})$ & 1316 & 12168 & 5080 & 100 \\
\hline $\mathrm{H}\left(1^{`} \mathrm{~N}\right)$ & $516(2)$ & 1321(3) & $5929(11)$ & $27(8)$ \\
\hline $\mathrm{H}\left(4^{\circ} \mathrm{A}\right)$ & 7420 & 11517 & 5881 & 57 \\
\hline $\mathrm{H}\left(4^{\circ} \mathrm{B}\right)$ & 8035 & 11437 & 5251 & 57 \\
\hline $\mathrm{H}\left(5^{\prime} \mathrm{A}\right)$ & 7327 & 13821 & 5016 & 51 \\
\hline $\mathrm{H}\left(5^{\circ} \mathrm{B}\right)$ & 6713 & 13900 & 5644 & 51 \\
\hline $\mathrm{H}\left(6^{6} \mathrm{~A}\right)$ & 5912 & 10530 & 4516 & 41 \\
\hline $\mathrm{H}\left(7^{\circ} \mathrm{N}\right)$ & $518(3)$ & $1321(4)$ & $4359(14)$ & $50(11)$ \\
\hline $\mathrm{H}(11 \mathrm{~A})$ & 1742 & 13975 & 3682 & 100 \\
\hline $\mathrm{H}(11 \mathrm{~B})$ & 1439 & 13700 & 3018 & 100 \\
\hline $\mathrm{H}(11 \mathrm{C})$ & 2556 & 14568 & 3206 & 100 \\
\hline $\mathrm{H}(12 \mathrm{~A})$ & 3621 & 11111 & 2793 & 76 \\
\hline $\mathrm{H}(12 \mathrm{~B})$ & 3713 & 12802 & 2659 & 76 \\
\hline $\mathrm{H}(12 \mathrm{C})$ & 2596 & 11933 & 2471 & 76 \\
\hline $\mathrm{H}(13 \mathrm{~A})$ & 2430 & 10266 & 3576 & 82 \\
\hline $\mathrm{H}(13 \mathrm{~B})$ & 1329 & 11037 & 3305 & 82 \\
\hline $\mathrm{H}(13 \mathrm{C})$ & 1760 & 11414 & 3945 & 82 \\
\hline $\mathrm{H}(17 \mathrm{~A})$ & 2564 & 7965 & 9475 & 33 \\
\hline $\mathrm{H}(18 \mathrm{~A})$ & 3240 & 10777 & 9082 & 37 \\
\hline $\mathrm{H}(18 \mathrm{~B})$ & 4080 & 9443 & 9168 & 37 \\
\hline $\mathrm{H}(20 \mathrm{~A})$ & 4240 & 7673 & 8409 & 59 \\
\hline $\mathrm{H}(21 \mathrm{~A})$ & 3905 & 7119 & 7433 & 87 \\
\hline $\mathrm{H}(22 \mathrm{C})$ & 2547 & 8413 & 6892 & 90 \\
\hline
\end{tabular}




\begin{tabular}{|c|c|c|c|c|}
\hline $\mathrm{H}(23 \mathrm{C})$ & 1521 & 10209 & 7314 & 75 \\
\hline $\mathrm{H}(24 \mathrm{~B})$ & 1834 & 10757 & 8272 & 50 \\
\hline $\mathrm{H}(27 \mathrm{~A})$ & 3248 & 10242 & 11255 & 106 \\
\hline $\mathrm{H}(27 \mathrm{~B})$ & 4245 & 9582 & 11653 & 106 \\
\hline $\mathrm{H}(27 \mathrm{C})$ & 3307 & 8538 & 11369 & 106 \\
\hline $\mathrm{H}(28 \mathrm{~A})$ & 4559 & 11385 & 10587 & 84 \\
\hline $\mathrm{H}(28 \mathrm{~B})$ & 5461 & 10416 & 10272 & 84 \\
\hline $\mathrm{H}(28 \mathrm{C})$ & 5654 & 10812 & 10936 & 84 \\
\hline $\mathrm{H}(29 \mathrm{D})$ & 4827 & 7093 & 10973 & 76 \\
\hline $\mathrm{H}(29 \mathrm{E})$ & 5821 & 8167 & 11172 & 76 \\
\hline $\mathrm{H}(29 \mathrm{~F})$ & 5625 & 7774 & 10509 & 76 \\
\hline $\mathrm{H}(18 \mathrm{~N})$ & $124(3)$ & $1038(4)$ & $9280(13)$ & $43(9)$ \\
\hline $\mathrm{H}(21 \mathrm{~A})$ & -1605 & 11107 & 9123 & 36 \\
\hline $\mathrm{H}(21 \mathrm{~B})$ & -247 & 11203 & 8977 & 36 \\
\hline $\mathrm{H}(22 \mathrm{~A})$ & -393 & 8921 & 8478 & 38 \\
\hline $\mathrm{H}(22 \mathrm{~B})$ & -1752 & 8824 & 8625 & 38 \\
\hline $\mathrm{H}(23 \mathrm{~A})$ & -1404 & 7706 & 9914 & 29 \\
\hline $\mathrm{H}(24 \mathrm{~N})$ & $-120(2)$ & 1049(3) & $10263(12)$ & $33(8)$ \\
\hline $\mathrm{H}(28 \mathrm{~A})$ & -1155 & 11889 & 12019 & 69 \\
\hline $\mathrm{H}(28 \mathrm{~B})$ & 132 & 11460 & 11940 & 69 \\
\hline $\mathrm{H}(28 \mathrm{C})$ & -459 & 11086 & 12525 & 69 \\
\hline $\mathrm{H}(29 \mathrm{~A})$ & 680 & 8907 & 11865 & 66 \\
\hline $\mathrm{H}(29 \mathrm{~B})$ & -258 & 7670 & 11813 & 66 \\
\hline $\mathrm{H}(29 \mathrm{C})$ & 21 & 8429 & 12418 & 66 \\
\hline $\mathrm{H}(30 \mathrm{~A})$ & -2626 & 10062 & 11970 & 60 \\
\hline $\mathrm{H}(30 \mathrm{~B})$ & -2043 & 9152 & 12483 & 60 \\
\hline $\mathrm{H}(30 \mathrm{C})$ & -2325 & 8394 & 11879 & 50 \\
\hline
\end{tabular}


Crystallographic data (excluding structure factors) for the structures reported in this paper have been deposited as supplementary publication no. CCDC-240722 (47a), CCDC-240723 (107b) and CCDC-240724 [(2S,2'R)-118] with the Cambridge Crystallographic Data Centre. Copies of the data can be obtained free of charge on application to The Director, CCDC, 12 Union Road, Cambridge CB2 1EZ, UK (Fax: (+44)1223-336-033; E-mail: deposit@ccdc.cam.ac.uk). 


\section{Aknowledgments}

I would like to thank Professor A. de Meijere for giving me the possibility to spend the years of my Ph.D. in his group, for the helpful discussions and explanations about the drawing up of publications.

For my participation at the academic activities I thank Professors W. Knepel, J. Magull and the Göttingen University.

I am very grateful to Mr. Machinek for the measurements of the NMR spectra. I thank Dr. Frauendorf and Mrs. Udvarnoki for the measurement of the mass spectra and Mr. Hambloch for the measurements of the elemental analyses. I am very grateful to Mr. D. Vidovic for the measurement of the X-Ray structures. I also thank very much the group of Professor Buback, for the attempts of carachterization of my polymers and for the helpful discussions. I wish to thank the group of Prof. Tietze for the introduction to the use of the microwave system.

I am very grateful to Dr. Sergej I. Kozhukov for his help in the drawing up of my first paper and for the help in the lab, during the preparation of my starting materials.

For his indefatigable help in the lab, and for the precious suggestions about the use of computers I am very grateful to Heiko. I thank a lot Farina for her untiring corrections in my first indipendent scientific works and for every time she helped me to menage in the life in a foreign country.

I thank Anna, Surya, Martina and particularly Farina and Marco for the correction of this work. I would like to thank all the members of the group of Prof. de Meijere, especially Anna, Daniel, Vesta, Boris, Surja, Viktor, Dr. Andrej S., Dr. Belov, Takuja, Baris, André and Shamil. A special thank to my collegues in the administrations of our NMR: Mario and Hans. I thank Mrs. G. Keil Knepel and Mr. Carsten Rauch and expecially Mr. Stefan Besshausen for helping me in any problem.

I thank Farina, Anna, Martina, Marco, Heiko and Jochen for their friendship. I really thank Hans, for his help in all the difficult periods I had in chemistry or in life and also for a lot of shared fun.

I wish to thank expecially my mother and Andrea, who, although faraway, have always been close to me with support and trust. 


\section{Publications List}

1. S. Cicchi, J. Revuelta, A. Zanobini, M. Betti, A. Brandi Synlett 2003, 15, 2305-2308. "Domino palladium(II)-mediated rearrangement-oxidative cyclization of $\beta$ aminocyclopropanols"

2. A. Zanobini, M. Gensini, J. Magull, D. Vidović, S. I. Kozhushkov, A. Brandi, A. de Meijere, Eur. J. Org. Chem. 2004, 4158-4166.

Part 102 in the series "Cyclopropyl Building Blocks for Organic Synthesis"

"A Convenient New Synthesis of 3-Substituted $\beta$-Lactams Formally Derived from 1(Aminomethyl)cyclopropanecarboxylic Acids"

3. A. Zanobini, A. Brandi, A. de Meijere, Chem. Eur. J. 2005, submitted.

Part 122 in the series "Cyclopropyl Building Blocks for Organic Synthesis"

"A New Three-Component Cascade Reaction to Yield 3-Spirocyclopropanated 2Azetidinones"

\section{Lectures}

1. "Microwave-assisted one-pot approach to 3-spirocyclopropanated monocyclic $\beta$-lactams", A. Zanobini, A. de Meijere, Fourth International Youth Conference on Organic Synthesis, June 27-30, 2005, St. Petersburg, Russia.

\section{Poster presentations}

1. "Azaanaloghi di Illudine: eterocicli spirociclopropanici alchilanti del DNA", S. Cicchi, A. Zanobini, A. Brandi, XXI Congresso Nazionale della Societá Italiana di Chemioterapia, December 2-5, 2001, Firenze, Italia. 


\section{Lebenslauf}

Ich wurde am 25. April 1977 als eiziges Kind von Pietro Zanobini und Elena Boccoli in Florenz, Italien, geboren.

Von September 1983 bis Juni 1988 besuchte ich die Grundschule „La Quiete. Istituto delle Montalve“ und von September 1988 bis Juni 1991 die Mittelschule in dem selbem Institut, in Florenz, Italien. Anschließend wechselte ich auf das humanistische Liceo Ginnasio Statale Niccoló Forteguerri in Pistoia, das ich von September 1991 bis Juni 1994 besuchte. Von September 1994 bis Juli 1996 besuchte ich das humanistische Liceo Ginnasio Statale Galileo in Florenz, wo ich im Juli 1996 das Abitur bestand. Zum Wintersemester 1996/97 nahm ich das Studium der Chemie an der Universitá degli studi di Firenze auf. Unter der wissenschaftlichen Anleitung von Prof. Dr. Alberto Brandi fertigte ich von Oktober 2001 bis Juli 2002 meine Diplomarbeit mit dem Thema „Reattivitá di Derivati Ciclopropanici con Pd(II). Sintesi di Composti Tetraidro e Diidropiridonici“ an. Am 23. Juli 2002 wurde mir den akademische Grad Diplom-Chemikerin zuerkannt. Seit Oktober 2002 arbeite ich im Arbeitskreis von Prof. Dr. Armin de Meijere an meiner Dissertation zum Thema „Synthesis of New Spirocyclopropanated $\beta$-Lactams and Their Application as Building Blocks for $\beta$-Amino Acids Peptides“. In der Zeit von Oktober 2003 bis Juni 2005 wurde ich mehrfach mit der Betreuung des organisch-chemischen Praktikums, zweimal mit der Betreuung der Übungen zur Vorlesung „Experimentalchemie II, Organische Chemie“, beauftragt. Im Sommersemester 2005 absolvierte ich erfolgreich einen Kurs der „Allgemeinen und systematischen Pharmakologie und Toxikologie“.

Ich besitze die italienische Staatsangehörigkeit. 
